\title{
241-AZ Tank Farm Construction Extent of Condition Review for Tank Integrity
}

\author{
T.J. Barnes, K.D. Boomer, J.R. Gunter, T.J. Venetz \\ Washington River Protection Solutions, LLC \\ Richland, WA 99352 \\ U.S. Department of Energy Contract DE-AC27-08RV14800

$\begin{array}{lll}\text { EDT/ECN: } & \text { DRF } & \text { UC: N/A } \\ \text { Cost Center: } & \text { 2KE00 } & \text { Charge Code: } 201522 \\ \text { B\&R Code: } & \text { N/A } & \text { Total Pages: } 141\end{array}$

Key Words: DST, 241-AZ Tank Farm, leak, tank construction, extent of condition

Abstract: This report provides the results of an extent of condition construction history review for tanks 241-AZ-101 and 241-AZ-102. The construction history of the 241-AZ tank farm has been reviewed to identify issues similar to those experienced during tank AY-102 construction. Those issues and others impacting integrity are discussed based on information found in available construction records, using tank AY-102 as the comparison benchmark. In the 241-AZ tank farm, the second DST farm constructed, both refractory quality and tank and liner fabrication were improved.

TRADEMARK DISCLAIMER. Reference herein to any specific commercial product, process, or service by trade name, trademark, manufacturer, or otherwise, does not necessarily constitute or imply its endorsement, recommendation, or favoring by the United States Government or any agency thereof or its contractors or subcontractors.

\section{APPROVED}

By G.E. Bratton at 2:38 pm, Jul 30, 2013

Release Approval

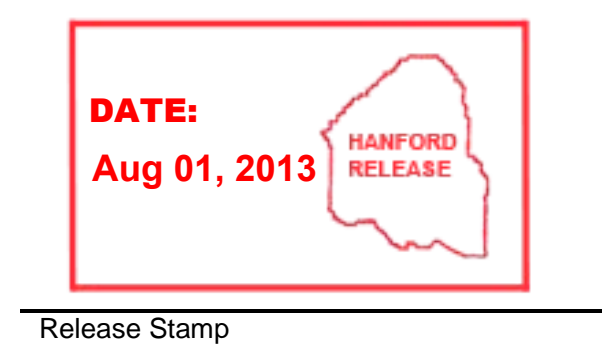

Release Stamp 


\section{1-AZ Tank Farm Construction Extent of Condition Review for Tank Integrity}

T. J. Barnes

K. D. Boomer

J. R. Gunter

T. J. Venetz

Washington River Protection Solutions, LLC

Date Published

July 2013

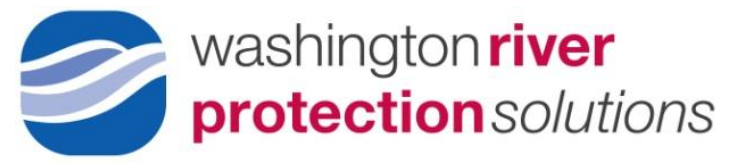

Prepared for the U.S. Department of Energy

Office of River Protection

Contract No. DE-AC27-08RV14800 
RPP-RPT-54818, Rev. 0

\section{EXECUTIVE SUMMARY}

The construction history of the 241-AZ tank farm has been reviewed to identify any concerns for the long-term integrity of the tanks. This initial review was prompted by construction issues identified during the formal leak assessment for tank 241-AY-102 (AY-102), RPP-ASMT-53793, Tank 241-AY-102 Leak Assessment Report. In AY-102, bulges in the secondary liner, deterioration of refractory during post-weld stress relieving (post-weld heat treatment), and primary tank floor plate welding rework during construction left residual stresses in the tank that may have accelerated corrosion and contributed to the primary tank failure. The main purpose of this review was to determine whether the construction methods adopted after completion of the 241-AY tank farm either improved the quality and integrity of the second double-shell tank farm built (241-AZ tank farm) or produced similar reduced margins.

During construction of the 241-AZ tank farm, fewer welding problems of the secondary liner and primary tank bottoms were noted compared to the 241-AY tank farm. The secondary liner bottom thickness in the 241-AZ tank farm was increased to 3/8 in. (from 1/4 in. in 241-AY tank farm) and only a minor mention of secondary liner irregularities was noted, requiring the refractory thickness to be increased to ensure a thickness of at least 8 inches in all locations. The thickness of the primary tank bottom was also increased from 3/8 in. in the 241-AY tank farm to $1 / 2$ " in the 241-AZ tank farm. The overall primary liner weld rejection rates were much lower in the 241-AZ tank farm. Refractory installation and weather protection were improved and although issues with this protection were noted, no significant refractory repairs were required. The post-weld stress relieving process required modifications, but the changes allowed for more efficient and effective heat treatment in tanks 241-AZ-101 (AZ-101) and 241-AZ-102 (AZ-102) compared to the tanks in the 241-AY tank farm.

The most significant deficiency found was the presence of plate laminations. Some surface grinding on the bottom plate of the primary tank occurred. In tank AZ-102, six plates in the upper shell ring were found to have laminations, with four of them severe enough to require replacement prior to heat treatment. Other minor issues, unique to the 241-AZ tank farm were noted. Both primary tanks had leaks found during the hydrostatic test. They were above the normal waste level and repaired without additional stress relieving. A square groove was discovered to have been ground into one weld in the lower knuckle in the tank AZ-101 primary side wall after heat treatment, but this condition was evaluated and accepted as-is. Fires occurred during construction in the annulus of tank AZ-102 and in the bottom of the primary tank in tank AZ-102 but the job logs did not indicate that any significant damage was caused by these two fires. These issues are not expected to significantly affect the tank integrity.

Following completion of the 241-AY tank farm, design evaluations and lesson learned meetings occurred to remedy issues encountered during construction and resulting changes were incorporated into the 241-AZ tank farm. Although there were improvements in the construction of 241-AZ tank farm, issues were still noted, some unique to tanks AZ-101 and AZ-102. Tanks AZ-101 and AZ-102 should remain in a category subject to enhanced inspection. 


\section{TABLE OF CONTENTS}

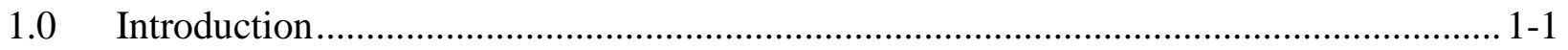

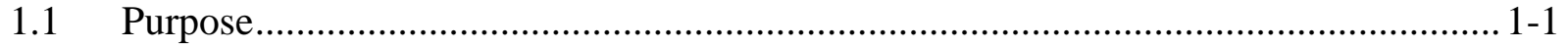

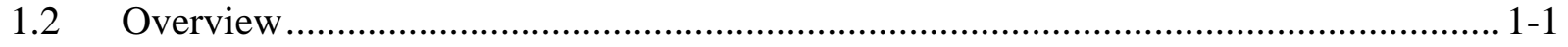

1.3 Double-Shell Tank Description........................................................................ 1-2

2.0 241-AZ Tank Farm Construction Information......................................................... 2-1

3.0 Materials of Construction …................................................................................ $3-1$

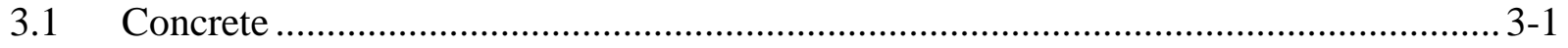

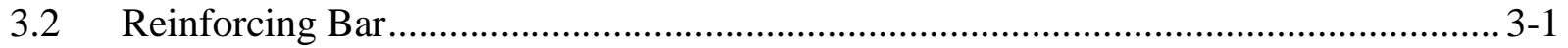

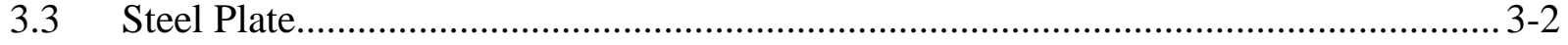

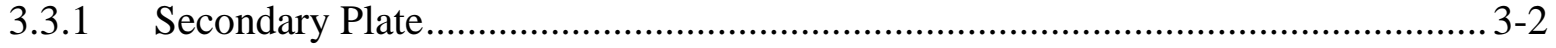

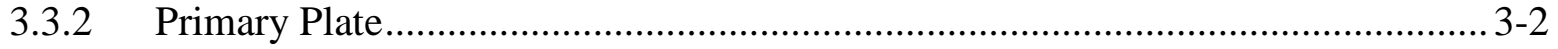

3.3.3 Material Certification........................................................................... $3-2$

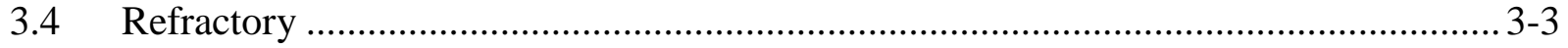

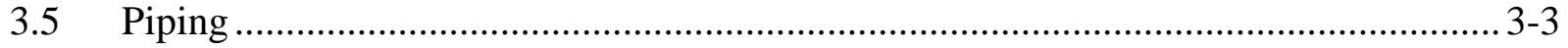

4.0 Construction Sequence........................................................................................ 4

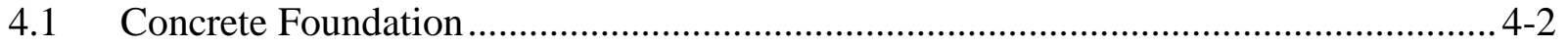

4.2 Secondary Liner Bottom ................................................................................... $4-3$

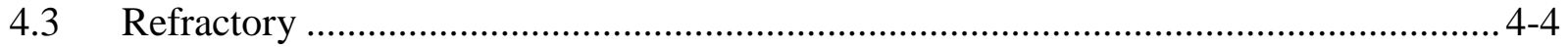

4.4 Secondary Liner Wall and Concrete Shell ................................................................ 4-6

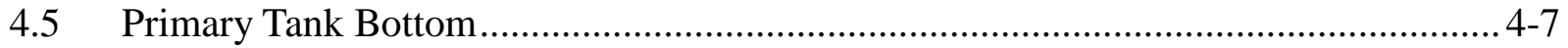

4.6 Primary Tank Wall and Tank Dome ...................................................................... 4-8

4.7 Primary Tank Stress Relieving.............................................................................. 4-9

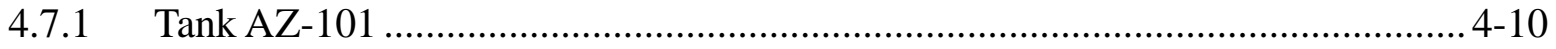

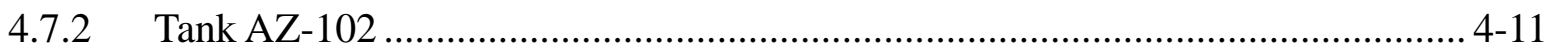

4.8 Primary Tank Hydrostatic Test......................................................................... 4-11

4.9 Complete Secondary Liner and Tank Penetrations .............................................. 4-12

4.10 Concrete Dome Pour...................................................................................... 4-14

4.11 Tank Appurtenances .............................................................................. 4-16

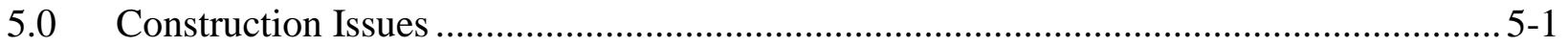

5.1 Weld Rejection and Non-Destructive Examination ..............................................5-1

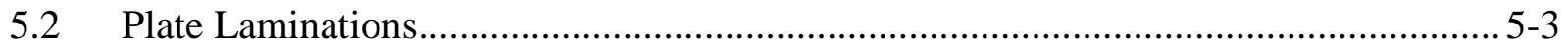

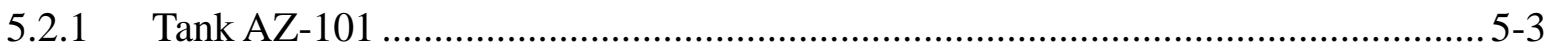

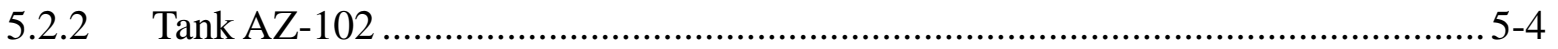




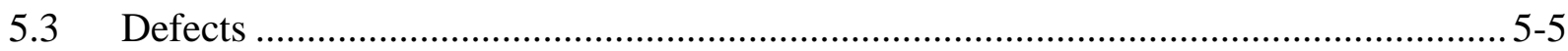

5.4 Weld Repairs Following Heat Treatment............................................................... 5-8

5.5 Minor Pitting from Hydrostatic Test Water ………………………......................... 5-8

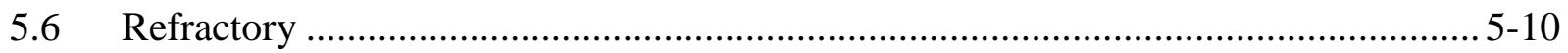

5.6.1 Refractory Material Choice Concerns and Mitigation......................................... 5-10

5.6.2 Installation Abnormalities ........................................................................... 5-10

5.6.3 Weather Protection .................................................................................... 5-14

5.7 Stress Relieving of the Primary Tank ............................................................. 5-18

5.8 Evaluation of Refractory After Hydrostatic Test .................................................... 5-19

5.9 Tank Bottom Flatness ………………………................................................. 5-21

5.10 Issues Unique to 241-AZ Tank Farm .................................................................. 5-21

5.10.1 Radiograph Misrepresentation Discovery...................................................... 5-21

5.10.2 Fires During Construction........................................................................... 5-22

5.10.3 Knuckles Swapped Between Tanks AZ-101 and AZ-102................................... 5-22

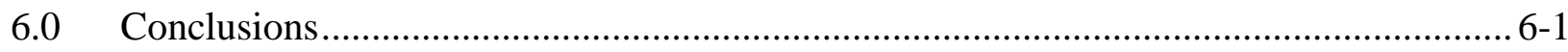

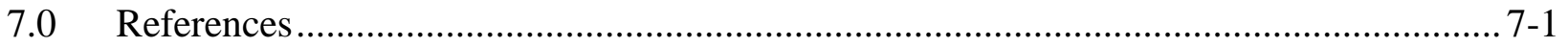

TABLE OF APPENDICES

APPENDIX A 241-AZ Tank Farm Key Event Table ............................................................... A-1

APPENDIX B 241-AZ Tank Farm Weld Maps ………………………………………....... B-1

APPENDIX C Tank Deficiency Documentation .................................................................. C-1

\section{LIST OF FIGURES}

Figure 1-1. Double-Shell Tank Design ......................................................................... 1-2

Figure 4-1. Progress on Tank Bases - Looking West (54511-15 Photo) (Taken 3/22/71)........... 4-2

Figure 4-2. Overall View of Foundation Construction - Looking West (53930-1 Photo)

(Taken 1/22/71) ......................................................................................................... 4-2

Figure 4-3. Viewing Erection of the Two Tanks’ Secondary Liners (55748-6 Photo) (Taken 8/25/71).

Figure 4-4. Constructing Secondary Liner - Looking North (55808-3 Photo) (Taken 8/30/71)

Figure 4-5. Secondary Liner Raised with Cribbing and Superstructure (55808-4 Photo) (Taken 8/30/71).

Figure 4-6. Tank AZ-101 Completed Castable Refractory Section Pour (55952-5 Photo) (Taken 9/17/71). 
Figure 4-7. Tank AZ-101 Air Distribution Ring, 4 in. Air Supply Line, and Air

Distribution Channels (55952-3 Photo) (Taken 9/17/71) ... 4-5

Figure 4-8. Refractory Retainer Ring and Ventilation Piping Interface (57482-17 Photo) (Taken 3/24/72).

Figure 4-9. Tank AZ-101 Forms Placed and Refractory Being Poured (55952-6 Photo)

(Taken 9/17/71)

Figure 4-10. Overall View of Tank Construction - Looking West (56502-1 Photo) (Taken $11 / 22 / 71)$ 4-6

Figure 4-11. Cross-Section of Primary Tank and Refractory ............................................. 4-7

Figure 4-12. Vertical Concrete Shell Pouring (56710-9 Photo) (12/21/71)............................. 4-7

Figure 4-13. Backfilling Operations (56929-11 Photo) (Taken 1/21/72) ................................ 4-7

Figure 4-14. Welders Repairing Welds on the Primary Tank Bottom Sections Looking South, Tank AZ-101 (56272-6 Photo) (Taken 10/26/71)...

Figure 4-15 Weld Repairs in Progress on Tank AZ-102 - Looking South (56272-4 Photo) (Taken 10/26/71). 4-8

Figure 4-16. Cross-Section of Primary Tank ................................................................... 4-8

Figure 4-17. Construction Progress on Tank AZ-101 (57174-14 Photo) (Taken 2/22/72) .......... 4-9

Figure 4-18. Insulation Installed and Held in Place with Wire Mesh on Tank AZ-102. (58073-4 Photo) (Taken 5/25/72)...

Figure 4-19. Worker Monitoring Chart Recorders for PWHT of Tank AZ-102 (58073-1 Photo) (Taken 5/25/72) . 4-11

Figure 4-20. Overview of Tank AZ-102 PWHT Activities (58073-5 Photo) (Taken $5 / 25 / 72)$ 4-11

Figure 4-21. Detail 9 from Sheet 2 of Drawing H-2-67317 Showing the Intersection Between the Secondary Liner and Primary Tank Dome.

Figure 4-22. Overall View Looking Northwest at Tank AZ-102 in the Background (58288-34 Photo) (Taken 6/20/72)...

Figure 4-23. Tank AZ-101 Reinforcing Steel and Concrete Forms Being Placed on Tank AZ-101 (58324-2cn Photo) (Taken 6/23/72) ... 4-15

Figure 4-24. Tank AZ-102 Haunch and Dome Concrete Pour Progress, Showing Forms and Truss System (58580-2 Photo) (Taken 8/3/72) . 4-15

Figure 4-25. Overall View of 241-AZ Tank Farm Following Concrete Dome Completion (58744-40 Photo) (Taken 8/22/72). 4-16

Figure 4-26. Looking at Completed Internals of Tank AZ-102 (58994-2 Photo) (Taken 9/20/72) 4-16

Figure 5-1. Tank AZ-101 Weld Grind Out in E-1 Seam .... 5-7

Figure 5-2. Refractory Over-Thickness (57482-20 Photo) (Taken 3/24/72) ..... 5-11 
Figure 5-3. 2 in. Bar Welded to the Retainer Ring to Support Air Distribution Piping (57482-17 Photo) (Taken 3/24/72)... $5-12$

Figure 5-4. Kaolite Retaining Ring with 1 in. Drainage Hole Drilled at Air Channel 5-13

Figure 5-5. Thermocouple Wiring Protection. (57482-16 Photo) (Taken 3/24/72). 5-14

Figure 5-6. Kaolite Condition (Damp, Soft for 1/8 in. Depth) (57482-18 Photo) (Taken $3 / 24 / 72$ ) 5-19

Figure 5-7. Kaolite Condition (Soggy and Mushy for 1/8 in. Depth) (57482-21 Photo) (Taken 3/24/72) $5-20$

Figure 5-8. Kaolite Condition (1/8 in. Crust) (57482-19 Photo) (Taken 3/24/72) $5-20$

\section{LIST OF APPENDIX FIGURES}

App Figure C-1. Tank AZ-101 Secondary Bottom Weld Map ................................................2

App Figure C-2. Tank AZ-102 Secondary Bottom Weld Map ................................................B-3

App Figure C-3. Tank AZ-101 Secondary Shell Weld Map (1 of 4) ..........................................4

App Figure C-4. Tank AZ-101 Secondary Shell Weld Map (2 of 4) ..........................................4

App Figure C-5. Tank AZ-101 Secondary Shell Weld Map (3 of 4) ..........................................5

App Figure C-6. Tank AZ-101 Secondary Shell Weld Map (4 of 4) .........................................5

App Figure C-7. Tank AZ-102 Secondary Shell Weld Map (1 of 4) .........................................6

App Figure C-8. Tank AZ-102 Secondary Shell Weld Map (2 of 4) .........................................6

App Figure C-9. Tank AZ-102 Secondary Shell Weld Map (3 of 4) .........................................7

App Figure C-10. Tank AZ-102 Secondary Shell Weld Map (4 of 4) ........................................7

App Figure C-11. Tank AZ-101 Primary Bottom Weld Map....................................................8-8

App Figure C-12. Tank AZ-102 Primary Bottom Weld Map ....................................................9

App Figure C-13. Tank AZ-101 Primary Shell Weld Map (1 of 4) ........................................B-10

App Figure C-14. Tank AZ-101 Primary Shell Weld Map (2 of 4) ........................................B-10

App Figure C-15. Tank AZ-101 Primary Shell Weld Map (3 of 4) ........................................B-11

App Figure C-16. Tank AZ-101 Primary Shell Weld Map (4 of 4) ........................................B-11

App Figure C-17. Tank AZ-102 Primary Shell Weld Map (1 of 4) ........................................B-12

App Figure C-18. Tank AZ-102 Primary Shell Weld Map (2 of 4) ..........................................-12

App Figure C-19. Tank AZ-102 Primary Shell Weld Map (3 of 4) ..........................................13

App Figure C-20. Tank AZ-102 Primary Shell Weld Map (4 of 4) ........................................B-13

App Figure D-1. Plate Laminations Nondestructive Test Report 72-41 (Dated 3/17/72) (2 Pages). 
App Figure D-2. Plate Laminations Nondestructive Test Report 72-41-1 (Dated 3/27/72)

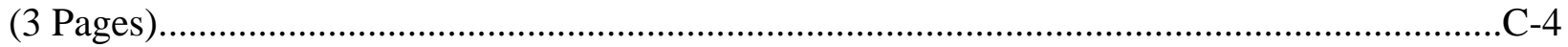

App Figure D-3. Plate Laminations Deficiency or Variation Report (Dated 4/27/72) .................-7

App Figure D-4. Weld Seam E-1 Grind Out Deficiency or Variation Report (Dated

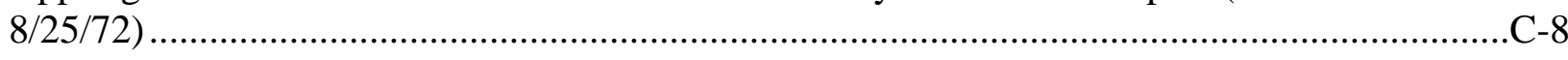

App Figure D-5. Letter from J.H. Slaughter to J.M. Frame Regarding Audit Findings (Dated 7/13/72).

App Figure D-6. Letter from E.F. Smith to J.H. Slaughter Regarding Audit Findings (Dated 7/28/72) (2 Pages)

App Figure D-7. Letter from W.C. Armstrong to J.H Slaughter Regarding Weld Seam E-1 Grind Out (Dated 8/24/72).

App Figure D-8. Letter from E.L Moore to W.C. Armstrong Regarding Pitting (Dated

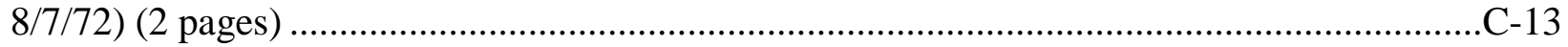

App Figure D-9. Refractory Thickness Deficiency or Variation Report (Dated 8/23/71).........C-15 App Figure D-10. Refractory Retaining Band Installed Upside Down Deficiency or Variation Report (Dated 10/6/71)

App Figure D-11. Retaining Band Slots and Drainage Holes Deficiency or Variation

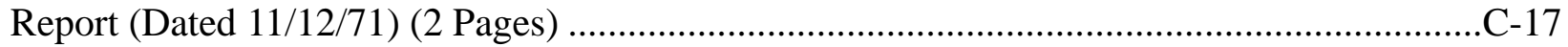

App Figure D-12. Refractory Guidance by Babcock and Wilcox (Dated 6/4/71) (4 Pages).....C-19

App Figure D-13. Protection of Kaolite - Action Taken (Dated 12/16/71) ..............................-23

App Figure D-14. Explanation of Frost Discovery and Actions Taken (Dated 12/20/1)...........C-24

App Figure D-15. Application of Auxiliary Heat to Tanks AZ-101 and AZ-102 (Dated

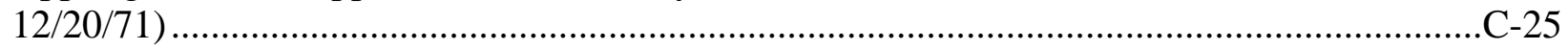

App Figure D-16. Stress Relieving Deficiency or Variation Report (Dated 5/4/72) .................C-26

App Figure D-17. Radiography Misrepresentation Memorandum (Dated 8/6/71) (2 Pages)

App Figure D-18. AZ 102 Knuckle Plates Deficiency or Variation Report (Dated 10/15/71) (2 Pages)

App Figure D-19. AZ 101 Knuckle Plates Deficiency or Variation Report (Dated 11/2/71) (2 Pages). 


\section{RPP-RPT-54818, Rev. 0}

\section{LIST OF TABLES}

Table 1-1. Double-Shell Tank Construction and Age as of 2013......................................... 1-2

Table 3-1. Material Comparison Between 241-AY and 241-AZ Tank Farms. .......................... 3-1

Table 4-1. Post-Weld Stress Relieving in 241-AZ Tank Farm.............................................. 4-10

Table 5-1. 241-AZ Tank Farm Primary Tank Bottom Weld Comparison.................................. 5-2

Table 5-2. 241-AY Tank Farm Primary Tank Bottom Weld Comparison ................................ 5-2

Table 5-3. 241-AZ Tank Farm Nondestructive Examinations Used During Construction.......... 5-3

Table 5-4. Significant Refractory Weather Events from Appendix A (2 Pages)...................... 5-15

Table 6-1. Summary Comparison 241-AZ Tank Farm Construction to Tank AY-102 ............... 6-2 
RPP-RPT-54818, Rev. 0

\section{LIST OF TERMS}

\section{Abbreviations and Acronyms}

AEC

ARHCO

ASMETM $^{\mathrm{TM}}$

ASTM $^{\text {TM }}$

DST

IDMS

LDP

NCR

NDE

PDM

PWHT

PUREX

RHA

SRP

SST

WADCO

WRPS

WST

WTP

\section{Units}

$\begin{array}{ll}\mathrm{ft} & \text { Feet } \\ \text { in } & \text { Inch } \\ \mathrm{h} & \text { Hour } \\ \mathrm{lb} & \text { Pound } \\ \text { gal } & \text { Gallon }\end{array}$

\author{
Atomic Energy Commission \\ Atlantic Richfield Hanford Company \\ American Society of Mechanical Engineers \\ American Society of Testing Materials \\ Double-Shell Tank \\ Integrated Data Management System \\ Leak Detection Pit \\ Non-Conformance Report \\ Non-Destructive Examination \\ Pittsburgh-Des Moines Steel Company \\ Post-Weld Heat Treatment ${ }^{1}$ (also referred to as \\ post-weld stress relieving and annealing) \\ Plutonium Uranium Extraction Process \\ Records Holding Area \\ Shell Ring Plate \\ Single Shell Tank \\ Westinghouse Advanced Development \\ Company \\ Washington River Protections Solutions LLC \\ Waste Storage Tank \\ Waste Treatment and Immobilization Plant
}

\section{TRADEMARK DISCLOSURE}

ASME is a registered trademark of American Society of Mechanical Engineers ASTM is a registered trademark of American Society for Testing and Materials Kaolite is a registered trademark of Babcock \& Wilcox Company

\footnotetext{
${ }^{1}$ This is the process used to relieve stresses in the material caused by welding.
} 


\subsection{INTRODUCTION}

This document provides an overview of the construction history noting any difficulties encountered for 241-AZ tank farm, the second double-shell tank (DST) farm constructed. In October 2012, it was determined that the primary tank of DST 241-AY-102 (AY-102) was leaking (RPP-ASMT-53793, Rev. 0, Tank 241-AY-102 Leak Assessment Report). Bulges in the secondary liner, deterioration of refractory during post-weld stress relieving, and primary tank floor plate welding rework during construction compromised the intended robustness and corrosion resistance of the tank AY-102 design and probably contributed to the primary tank's failure in tank AY-102.

Following identification of the tank AY-102 probable leak cause, an Extent of Condition (EOC) evaluation was prepared using U.S. Department of Energy's Energy Facilities Contractors Group (EFCOG) Guidance for Extent of Conditions Evaluations. The EFCOG process was used to identify other DSTs with construction, waste storage, or thermal histories similar to that of tank AY-102 (WRPS-1204931, Double-Shell Tank 241-AY-102 Primary Tank Leak Extent of Condition Evaluation and Recommended Annulus Visual Inspection Intervals). The EOC evaluation identified six tanks with similar construction and operating histories for additional evaluation which include: 241-AY-101, 241-AZ-101, 241-AZ-102, 241-SY-101, 241-SY-102, and 241-SY-103. One of the identified evaluations was to identify any similarities in construction that could be a precursor for accelerated corrosion and premature failure.

\subsection{PURPOSE}

The construction history of the 241-AZ tank farm has been reviewed to identify issues similar to those experienced during tank AY-102 construction. In this document, those issues and others impacting integrity are discussed based on information found in available construction records, using tank AY-102 as the comparison benchmark.

\subsection{OVERVIEW}

Six double-shell tank (DST) farms were constructed over a period of roughly 18 years (from 1968 to 1986), with a presumed design life of 20 to 50 years. 241-AZ tank farm was the second DST farm to be constructed and is the focus of this report. Table 1-1 provides the construction dates, year of initial service, and the expected service life for the DSTs. Following completion of the first DST farm, 241-AY tank farm, design evaluations and lesson learned meetings occurred to remedy issues encountered during construction and were incorporated into the design and fabrication of the 241-AZ tank farm. Discussion of the resulting quality of construction and any issues noted are captured herein. 
Table 1-1. Double-Shell Tank Construction and Age as of 2013

\begin{tabular}{|c|c|c|c|c|c|c|}
\hline $\begin{array}{c}\text { Tank } \\
\text { Farm }\end{array}$ & $\begin{array}{c}\text { Number of } \\
\text { Tanks }\end{array}$ & $\begin{array}{c}\text { Construction } \\
\text { Period }\end{array}$ & $\begin{array}{c}\text { Construction } \\
\text { Project }\end{array}$ & $\begin{array}{c}\text { Initial } \\
\text { Operation }\end{array}$ & $\begin{array}{c}\text { Service } \\
\text { Life }\end{array}$ & $\begin{array}{c}\text { Current } \\
\text { Age }\end{array}$ \\
\hline 241-AY & 2 & $1968-1970$ & IAP-614 & 1971 & 40 & 42 \\
\hline 241-AZ & 2 & $1970-1974$ & HAP-647 & 1976 & 20 & 37 \\
\hline 241-SY & 3 & $1974-1976$ & B-101 & 1977 & 50 & 36 \\
\hline 241-AW & 6 & $1976-1979$ & B-120 & 1980 & 50 & 33 \\
\hline 241-AN & 7 & $1977-1980$ & B-130, B-170 & 1981 & 50 & 32 \\
\hline 241-AP & 8 & $1982-1986$ & B-340 & 1986 & 50 & 27 \\
\hline Total & 28 & & & & & \\
\hline
\end{tabular}

\subsection{DOUBLE-SHELL TANK DESCRIPTION}

Each DST consists of a primary carbon steel tank, $75 \mathrm{ft}$. in diameter, inside of a secondary carbon steel liner, which is surrounded by a reinforced-concrete shell. Both the primary tank and secondary liner are constructed in four courses. The primary steel tank rests atop an eight inch insulating concrete slab, separating it from the secondary steel liner, and providing for air circulation/leak detection channels under the primary tank bottom plate. An annular space of 2.5 $\mathrm{ft}$. exists in between the secondary liner and primary tank, allowing for visual examination of the tank wall and secondary liner annular surfaces and ultrasonic volumetric inspections of the primary tank walls and secondary liners, as well as other activities.

\section{Figure 1-1. Double-Shell Tank Design}

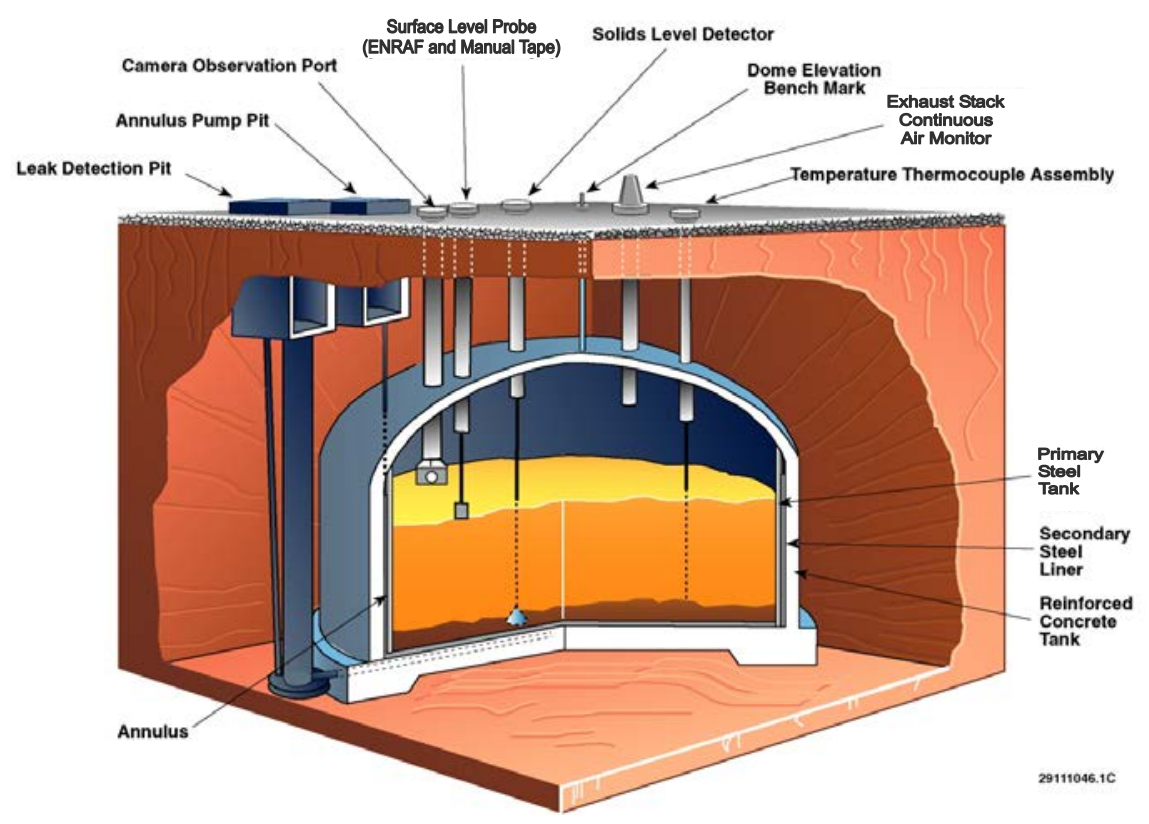


Each of the DSTs in the 241-AZ tank farm has 105 risers penetrating the dome, providing access for video cameras, ultrasonic inspection devices, waste sampling devices, mixer pumps, and other equipment which requires access to either the primary tank interior or annular space. Drawing H-14-010507, Sheet 1, Dome Penetration Schedules (WST/WSTA) Tank 241-AZ-101, and Sheet 2, Dome Penetration Schedules (WST/WSTA) Tank 241-AZ-102, provides a complete depiction of these tank penetrations. Above each 241-AZ DST are four pits, extending from grade to varying depths, which house valves and pumps, shown on drawing H-14-010507, Sheet 1 and 2. 


\section{$2.0 \quad$ 241-AZ TANK FARM CONSTRUCTION INFORMATION}

The 241-AZ tank farm was constructed between 1970 and 1974. It was designated as Project HAP-647, Tank Farm Expansion 241-AZ Tank Farm. The Atlantic Richfield Hanford Company (ARHCO) built the tank farm for the Atomic Energy Commission (AEC). The 241-AZ tank farm contained two tanks and ancillary equipment. The tanks were designed and designated as aging waste tanks for receipt of PUREX waste. Pittsburgh-Des Moines Steel Company (PDM), the contractor selected to build the tank farm, was also the contractor selected for the 241-AY tank farm, which was the first double-shell tank (DST) farm. Construction management was provided by Vitro Engineering.

The 241-AZ tank farm was built according to ARH-1437, Design Criteria Purex AZ Tank Farm, and the following construction specifications:

- HWS-8981, Specifications for Excavation and Tank Foundations

- HWS-8982, Specifications for Primary and Secondary Steel Tanks

- HWS-8867, Specification for Completion of Tank 102

To obtain information about the construction of 241-AZ tank farm, the Record Holding Area (RHA) and Integrated Data Management System (IDMS) were queried for boxes containing files from Project HAP-647, Tank Farm Expansion, 241-AZ.

This information includes:

1. Weld Radiography

2. Materials Certifications

3. Non-conformance reports

4. Quality Assurance construction log books

5. Project reports, correspondence, and meeting minutes

The following sections provide an aggregation of the information collected, highlighting important events and information relevant to leak integrity. From the information collected, the resulting quality of construction and any issues or difficulties noted are discussed in this document. 


\subsection{MATERIALS OF CONSTRUCTION}

The materials of construction evolved from the construction of the 241-AY tank farm to the construction of the 241-AZ tank farm. The primary change in material selection was to increase the thickness of the secondary liner and primary tank bottom plates. The refractory material and pour pattern were also modified.

Table 3-1. Material Comparison Between 241-AY and 241-AZ Tank Farms.

\begin{tabular}{|c|c|c|}
\hline \multirow[t]{2}{*}{ Material } & \multicolumn{2}{|c|}{ Tank Farm } \\
\hline & 241-AY & 241-AZ \\
\hline Concrete & $\begin{array}{l}3000 \text { psi } \\
\text { Type V for the walls; Type III for the } \\
\text { upper haunch and dome }\end{array}$ & $\begin{array}{l}3000 \text { psi } \\
\text { Type V for the walls; Type III for the } \\
\text { upper haunch and dome }\end{array}$ \\
\hline $\begin{array}{l}\text { Reinforcing } \\
\text { Bar }\end{array}$ & A432 & A615-60 \\
\hline Steel Plate & ASTM A515-65 & ASTM A515-69 \\
\hline Refractory & Kaolite $^{2}$ 2200LI & Kaolite 2000 \\
\hline
\end{tabular}

\subsection{CONCRETE}

All concrete used in the concrete shell vertical wall and dome required a 3,000 psi, 28-day compressive strength. The concrete samples were taken and tested at 7 days and 28 days to confirm the compressive strength. The cement for structural concrete conformed to Federal Specification SS-C-192 Type V, except what was used for the haunch and dome sections of the DSTs conformed to Type III, as described in HWS-8867. Type III cement is high early strength cement and Type $\mathrm{V}$ cement is high sulfate resistant cement.

\subsection{REINFORCING BAR}

The reinforcing bar was manufactured to American Society of Testing and Materials (ASTM ${ }^{3}$ ) TM A615, Grade 60 specifications with minimum yield strength of 60,000 psi. The tank foundation was reinforced with \#5, \#6, and \#7 rebar (see H-2-67243, Structural Concrete Tank Foundation Plan and Details, for details) while the concrete walls and dome sections were reinforced with \#4, \#6, \#8, and \#9 rebar (see H-2-67245, Concrete Tank Section and Haunch Reinforcement, for details).

\footnotetext{
${ }^{2}$ Kaolite is a registered trademark of Babcock \& Wilcox Company

${ }^{3}$ ASTM is a registered trademark of American Society for Testing and Materials
} 


\subsection{STEEL PLATE}

All sheet steel used in the 241-AZ tank farm primary tank and secondary liner construction was shipped from the United States Steel Corporation and was manufactured to ASTM A515, Carbon Steel, for Intermediate and High Temperature Service, Grade 60, standards. The tanks were erected using the 1968 Edition of the ASME ${ }^{4}$ Boiler and Pressure Vessel Code.

\subsubsection{Secondary Plate}

The secondary liner consists of 3/8 in. thick bottom plates and a 1/2 in. thick knuckle sections. The walls of the secondary liner are 3/8 in. thick. Drawing H-2-67317, Tanks 101 and 102 Section and Details 241-AZ Tank Farm, shows these details.

\subsubsection{Primary Plate}

The primary tank bottom primarily consists of $1 / 2$ in. carbon steel plates, except for the 4 foot diameter center which is composed of a 1 in. thick carbon steel plate, and a 7/8 in. carbon steel plate is used for the primary tank bottom knuckle.

The primary tank wall varies from $7 / 8$ in. thick carbon steel at the bottom knuckle to $3 / 8$ in. thick at the top transition plate. The first course is $3 / 4$ in. thick, and the next two courses are $1 / 2$ in. thick.

The top transition plate is welded to a 3/8 in. thick top knuckle. The top knuckle is then welded to the primary tank dome, which is constructed of mostly $3 / 8$ in. thick plates with the center portion of the dome having a thickness of 1/2 in. Drawing H-2-67317 shows these details.

\subsubsection{Material Certification}

Material certifications and chemical and physical test reports were required for each steel plate which was identified by a heat and slab number.

Material certifications contained yield and tensile strength information along with percent elongation for each specific heat and slab number.

The chemical and physical test reports identified the percent of each element (i.e., carbon, manganese, phosphorus, etc.) contained within a sample of the material as well as properties such as, yield point, tensile strength, percent elongation, and information gathered from bend test results.

\footnotetext{
${ }^{4}$ ASME is a registered trademark of American Society of Mechanical Engineers
} 
RPP-RPT-54818, Rev. 0

\subsection{REFRACTORY}

The castable refractory was required to limit the structural concrete base slab to a maximum temperature of $500^{\circ} \mathrm{F}$. The material had to have a minimum compressive strength of $130 \mathrm{psi}$ after heating either wet or dry. In addition, the material had to be compatible with the tank waste chemistry. Kaolite 2000 (Kaolite) was used as the insulating refractory in the 241-AZ tank farm.

\subsection{PIPING}

All pipe used for permanent risers was manufactured to ASTM A53, Grade B, Type E or S, or ASTM A106, Grade A or B specifications. Flanges conformed to ASTM A181, Grade I specifications. Coal tar enamel with bonded asbestos felt wrap and an outer wrapping of kraft paper was used for corrosion protection for un-insulated black steel pipelines (HWS-8867). 


\subsection{CONSTRUCTION SEQUENCE}

Construction of the two 241-AZ farm tanks was awarded to PDM. Excavation began in 1970 and the project was completed in 1974. The construction manager was Vitro Engineering. Following completion of the excavation work, the construction sequence of the 241-AZ tank farm tanks proceeded as follows:

1. Install concrete foundation on which the secondary liner bottom rests. The foundation has a tertiary leak detection system, which includes a waffle grid in the structural concrete, collection pipes, and a leak detection pit.

2. Fabricate and inspect the secondary liner bottom up to the top of the bottom knuckle plate, elevating it onto cribbing to facilitate access to the underside.

3. Inspect secondary liner bottom.

4. Lower the secondary liner bottom onto the concrete foundation using a truss assembly.

5. Fabricate and inspect the secondary liner wall up to the placement of the secondary top knuckle.

6. Install the air supply piping, and thermocouple conduits, to be embedded in the refractory as well as the retainer ring used as a form for the perimeter of the refractory.

7. Install refractory (during secondary liner wall erection).

8. Fabricate and inspect the primary tank bottom up to the top of the bottom knuckle plates, elevating it onto cribbing to facilitate access to the underside.

9. Inspect primary tank bottom.

10. Lower the primary tank bottom onto the refractory.

11. Place the concrete shell.

12. Start backfilling the tank farm area.

13. Fabricate and inspect the primary tank walls and wall penetrations.

14. Install temporary center support post to support dome sections.

15. Fabricate and inspect the primary tank dome and dome penetrations.

16. Install tank dome support superstructure (truss) to support the dome during concrete pour.

17. Insulate and provide stress relief of the primary tank.

18. Conduct hydrostatic test of the primary tank.

19. Complete fabrication of the secondary liner and penetrations.

20. Place concrete over the upper haunch area and tank dome.

21. Remove the tank superstructure after dome concrete cured.

22. Install appurtenances (thermocouple trees, airlift circulators, etc.).

23. Backfill to top of the dome.

24. Install the waste transfer system of piping, pump pits, and valve pits.

25. Complete backfill. 


\subsection{CONCRETE FOUNDATION}

The structural reinforced concrete foundation is $89 \mathrm{ft} .6 \mathrm{in}$. in diameter and is designed to distribute all weight loads uniformly. The circular center portion of the foundation is $6 \mathrm{ft}$. in diameter and $2 \mathrm{ft}$. thick. From the circular center portion, the foundation thickness decreases linearly out to about $1 \mathrm{ft}$. thickness at the $12 \mathrm{ft}$. $8 \mathrm{in}$. diameter and maintains that thickness out to the $47 \mathrm{ft} .9 \mathrm{in}$. diameter. The thickness then increases linear to a thickness of $2 \mathrm{ft}$. over the next 8 $\mathrm{ft}$., radially. The $2 \mathrm{ft}$. thickness is maintained to the perimeter of the tank at the $89 \mathrm{ft} .6 \mathrm{in}$. diameter. The structural foundation contains slots to direct any leakage to drain lines which empty to a leak detection pit (LDP). The foundation is composed of reinforced steel and concrete, requiring a 3000 psi, 28-day compressive strength (see drawing H-2-67243, Structural Concrete Tank Foundation Plan and Details, for details). Figure 4-1 shows the foundation prior to the placement of the concrete and the rebar and wood used to form the slots. Figure 4-2 shows the completed tank foundations, including the slots that direct any accumulation of liquid to the drain lines. Tank AZ-101 is in the foreground and tank AZ-102 can be seen in the background.

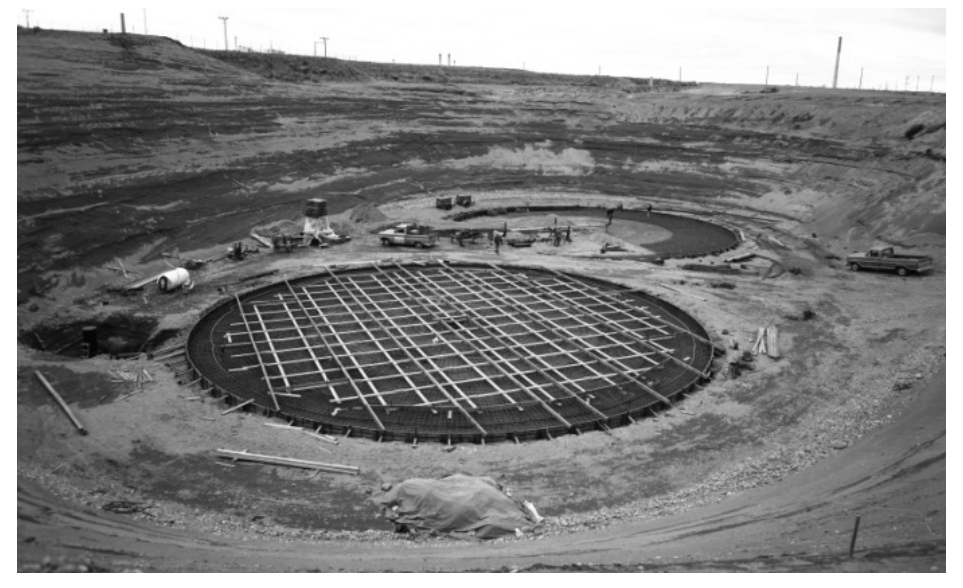

Figure 4-1. Progress on Tank Bases - Looking West (54511-15 Photo) (Taken 3/22/71)

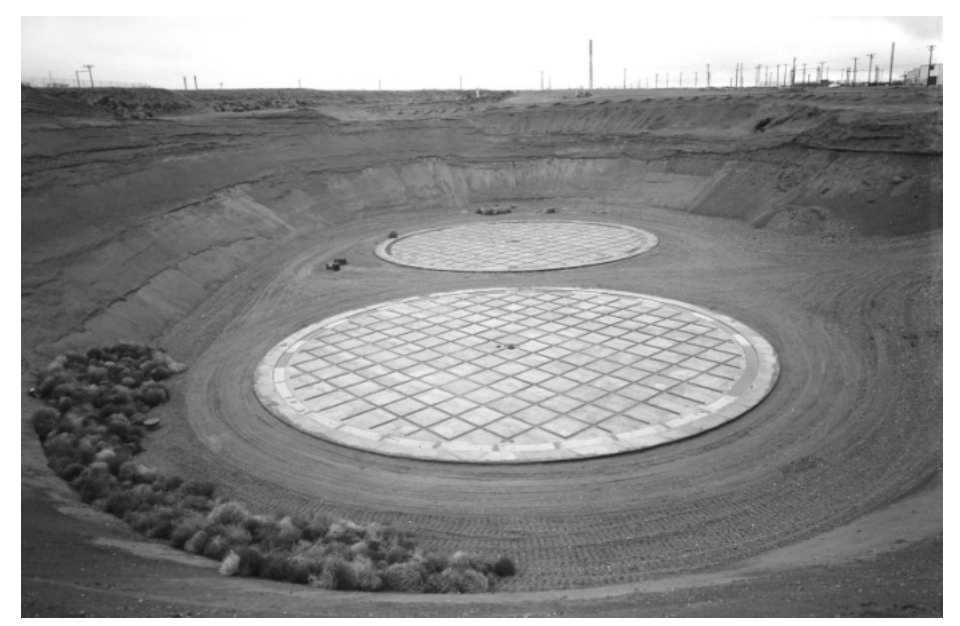

Figure 4-2. Overall View of Foundation Construction - Looking West (53930-1 Photo) (Taken 1/22/71) 


\subsection{SECONDARY LINER BOTTOM}

The secondary liner bottom was constructed onsite on top of the concrete foundation, with a protective cover installed to minimize damage to the concrete. The secondary liner bottom knuckles were fabricated offsite at a PDM fabrication facility in Provo, Utah, prior to being shipped to the worksite for welding to join the knuckles with the adjacent plates. The secondary liner bottom plates are 3/8 in. thick carbon steel, increased from the 1/4 in. thick plates in the 241-AY tank farm, and the bottom knuckles are made of $1 / 2$ in. thick carbon steel. The secondary liner is $80 \mathrm{ft}$. in diameter and is shown in Figure 4-3.

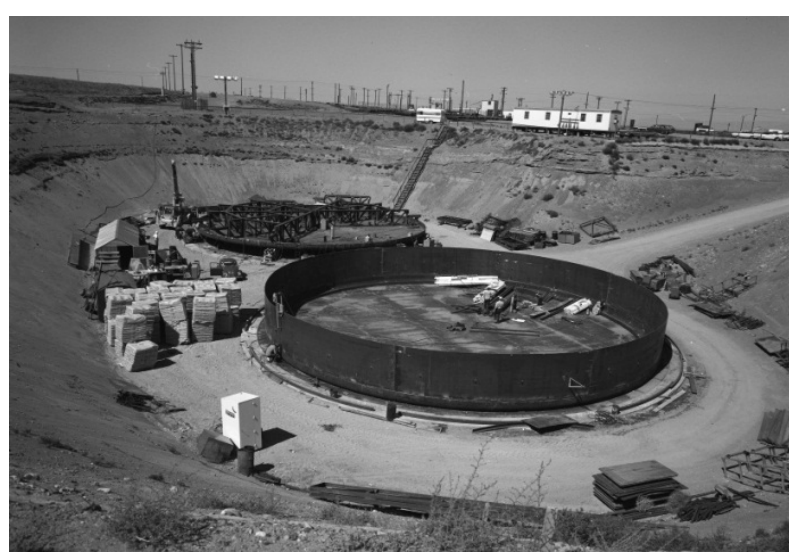

Figure 4-3. Viewing Erection of the Two Tanks' Secondary Liners (55748-6 Photo) (Taken 8/25/71)

Individual plates would be placed on the concrete foundation, and fabricators would use fit-up tools to secure the plates within the allowable tolerance to allow for proper welding. After completion of fabrication on the top side of the secondary plates, the fabricator raised the secondary liner bottom to gain access to the bottom side of the plates. The secondary liner bottom was raised with hydraulic jacks, and cribbing was installed under the secondary liner to allow workers to gain access to the underside.

After completion and inspection of the welds, as described in Table 5-3, in Section 5.1 the secondary liner bottom was lowered, using a superstructure that supported it from the top to limit deformation. Figure 4-4 and Figure 4-5 show the super structure and cribbing that was used

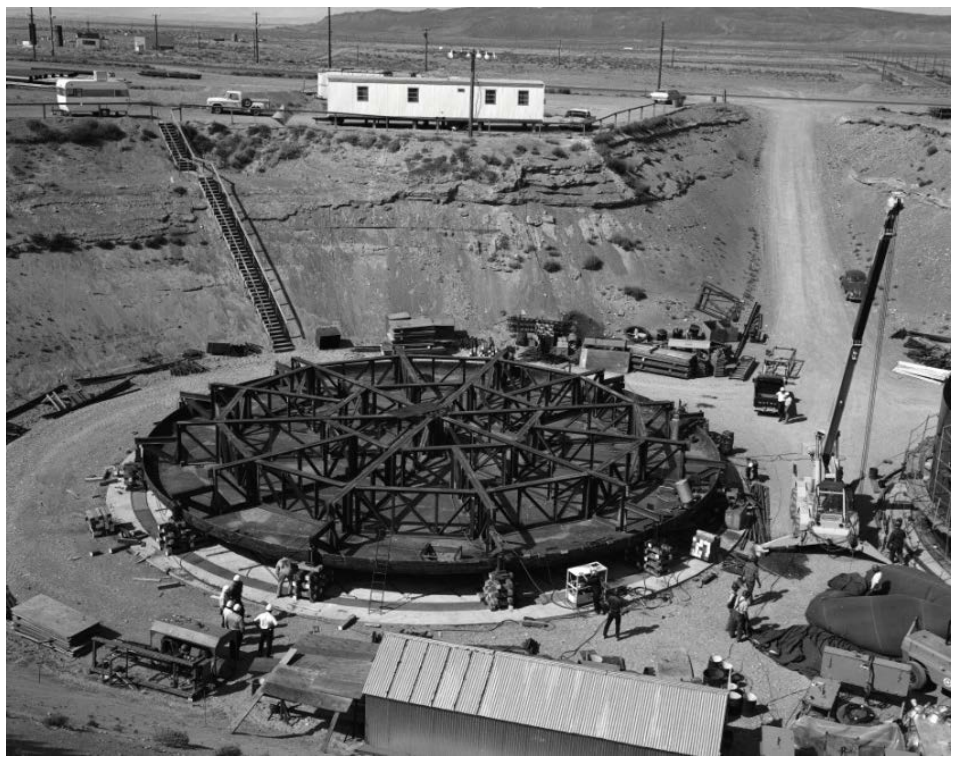

Figure 4-4. Constructing Secondary Liner - Looking North (55808-3 Photo) (Taken 8/30/71) to elevate the secondary liner, facilitating welding activities. Prior to lowering the secondary liner bottom down onto the concrete foundation, the slots and center sump region of the foundation were cleaned with the knowledge that further access into these locations would not be provided again. 


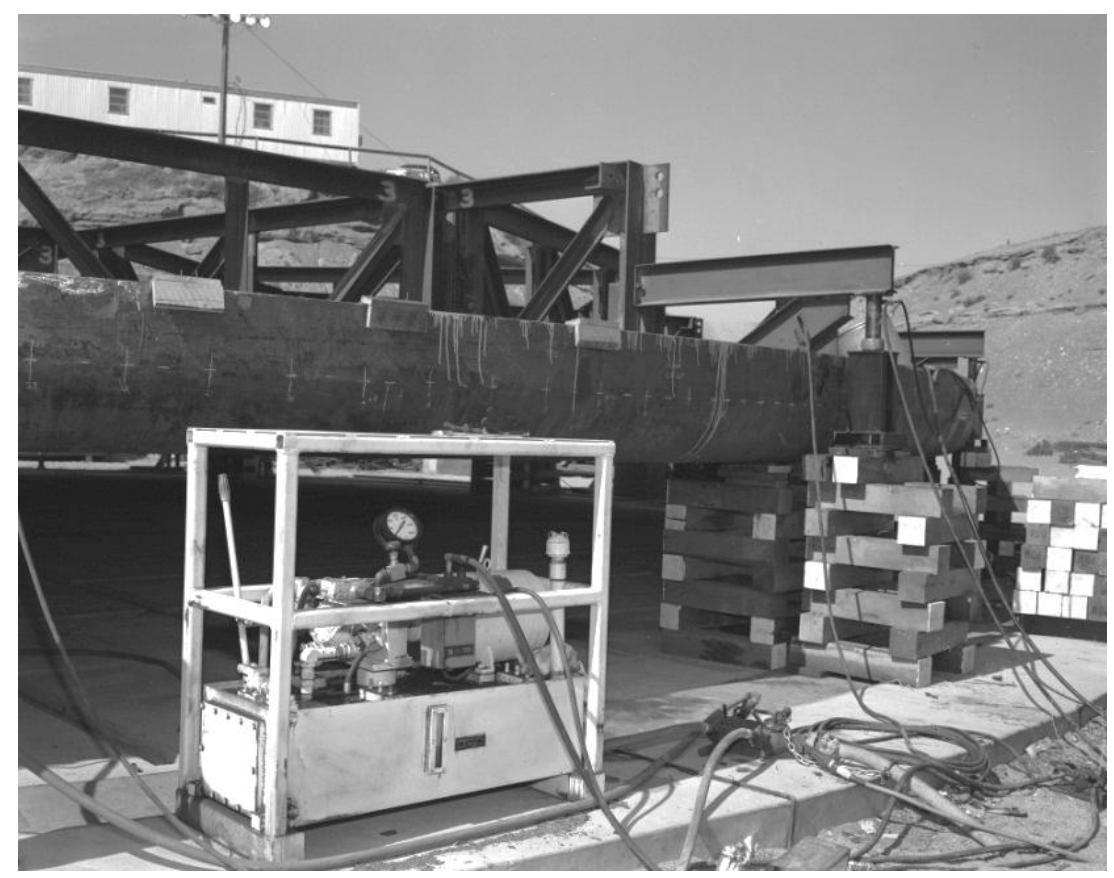

Figure 4-5. Secondary Liner Raised with Cribbing and Superstructure (55808-4 Photo) (Taken 8/30/71)

\subsection{REFRACTORY}

The primary purpose of the refractory was to act as an insulating barrier between the primary tank and the concrete foundation during the stress relieving process where temperatures could damage the concrete if not protected. The refractory design used for the two 241-AZ tank farm tanks specified a nominal 8 in. layer of Kaolite to be located between the primary tank and secondary liner bottom. The refractory pad also housed air ventilation piping, thermocouple conduit, and air distribution slots. The air distribution slots, patterned differently than those in the 241-AY tank farm, allowed airflow to cool the primary tank bottom and to direct potential leaks to the tank annulus where leak detection instrumentation is installed (see H-2-67317,

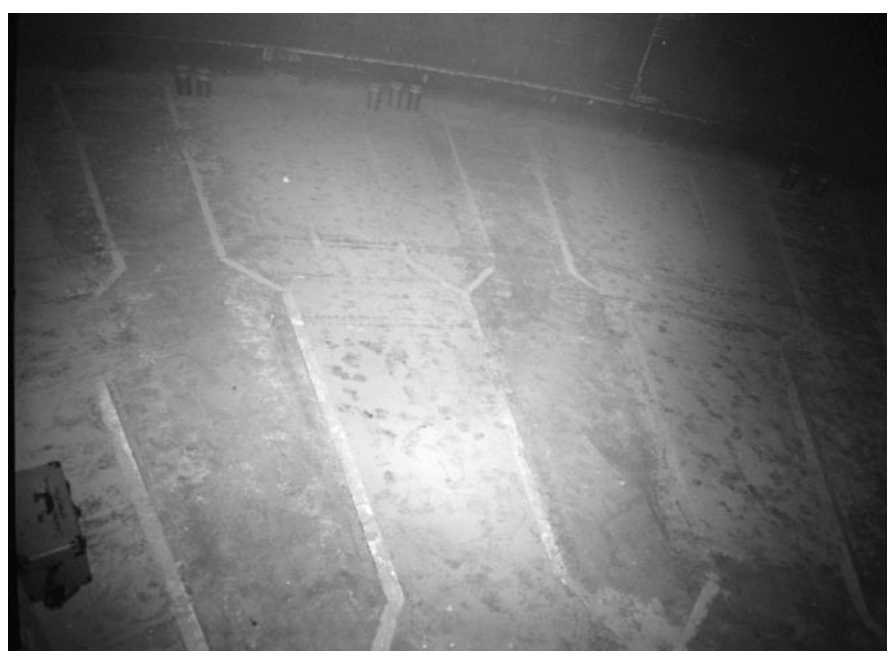

Figure 4-6. Tank AZ-101 Completed Castable Refractory Section Pour (55952-5 Photo) (Taken 9/17/71) Tanks 101 \& 102 Section \& Details 241-AZ Tank Farm). Figure 4-6 shows a completed section of refractory before the forms for the air circulation grooves were removed. 
Prior to installing the refractory, thermocouple conduit was installed and located as necessary to allow temperature monitoring of the primary tank bottom once placed into service. Four ventilation pipes were installed in the refractory, terminating at the center of the foundation with an air distribution ring. Figure 4-7 shows the interface between the four, 4 in. ventilation pipes and the air distribution ring. Air is drawn through this ventilation piping to the air distribution ring and out along the air distribution slots in the refractory. The structure above the air distribution ring is a screed used to smooth the refractory surface.

Following the installation of the ventilation piping, center air distribution ring, and thermocouple conduit, a 7 in. $x$ 3/4 in. retainer ring was installed along the perimeter of the yet to be installed refractory. The retainer ring was to act as a form and to contain any spalling material during installation of the refractory. The ventilation piping and the thermocouple conduit penetrate through the retainer ring. Figure 4-8 shows the ventilation piping penetration. Figure 4-9 shows the work practices utilized for refractory pouring and shows a hole that was cut into the side of the secondary liner to allow entry of workers and materials. These holes were cut into both tanks AZ-101 and AZ-102. They were later sealed in January 1972 as is discussed in the daily logbooks. The logbook entries are summarized

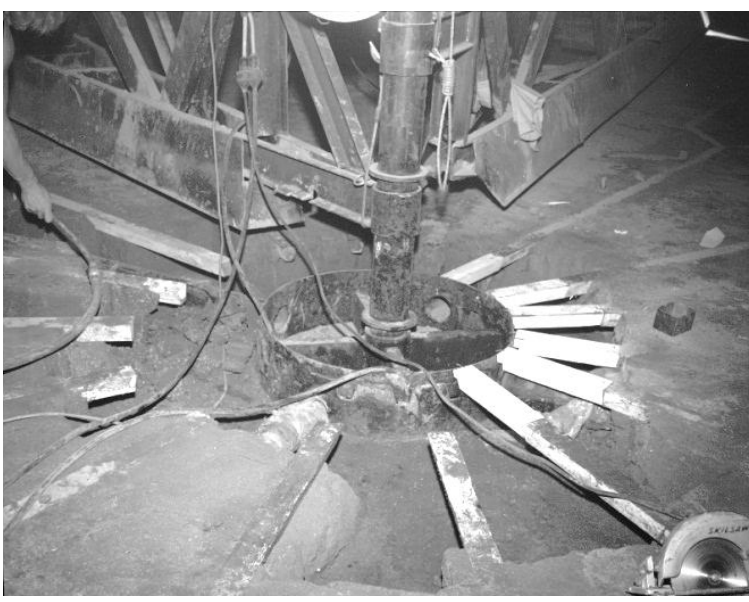

Figure 4-7. Tank AZ-101 Air Distribution Ring, 4 in. Air Supply Line, and Air Distribution Channels (55952-3 Photo) (Taken 9/17/71)

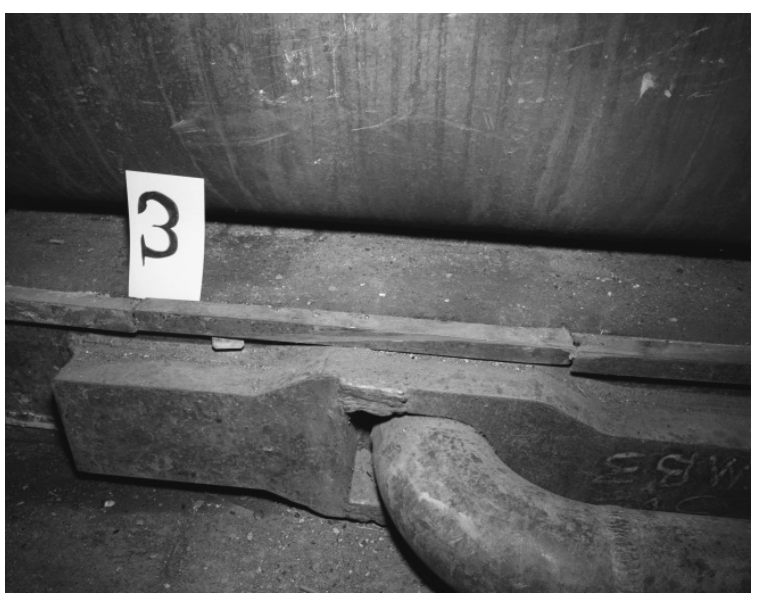

Figure 4-8. Refractory Retainer Ring and Ventilation Piping Interface (57482-17 Photo) (Taken 3/24/72)

in Appendix A and provide additional details of the sealing which occurred between January $13^{\text {th }}$ and $19^{\text {th }}$ of 1972. 


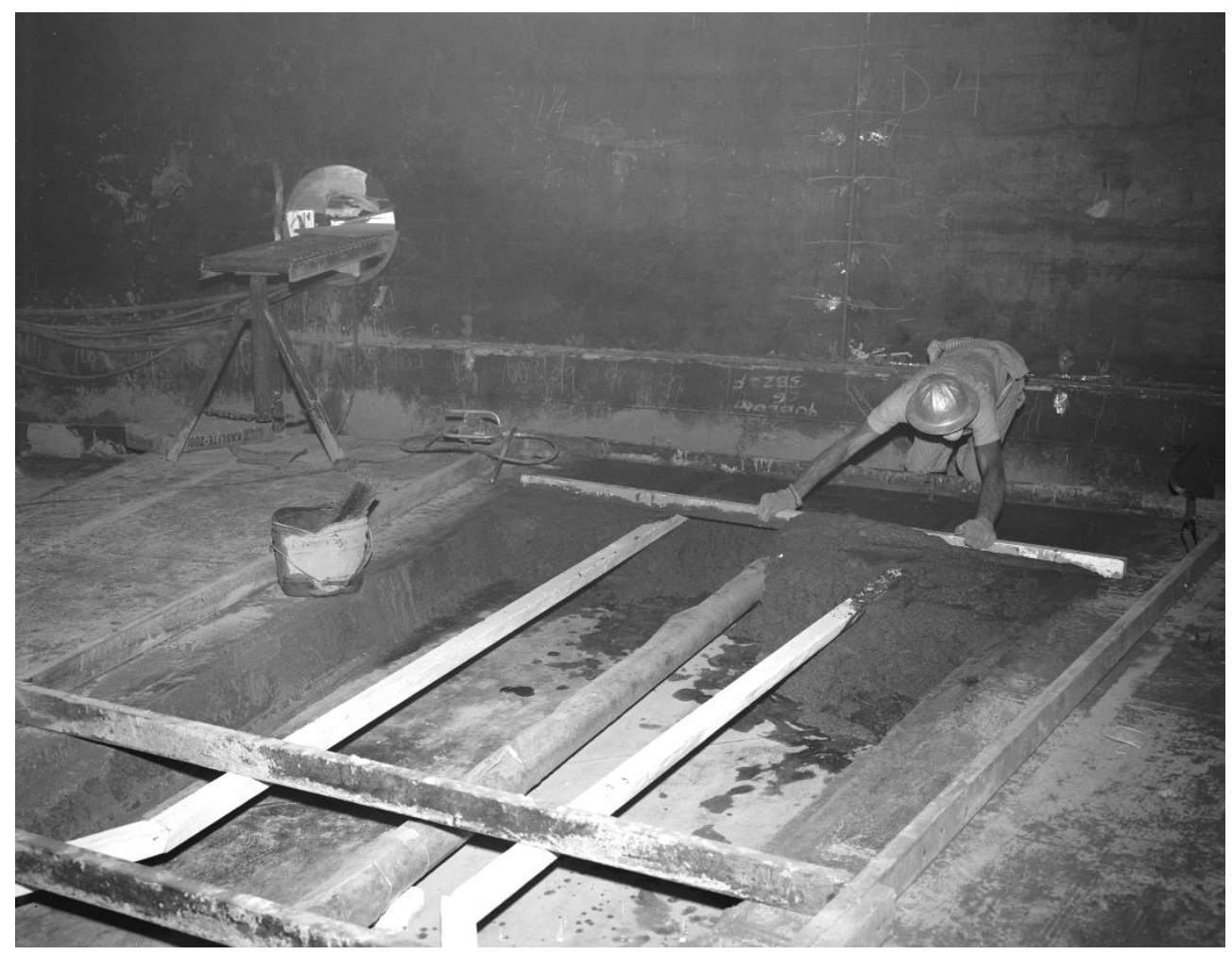

Figure 4-9. Tank AZ-101 Forms Placed and Refractory Being Poured (55952-6 Photo) (Taken 9/17/71)

\subsection{SECONDARY LINER WALL AND CONCRETE SHELL}

Following the secondary liner bottom fabrication, work began on the secondary liner wall. The secondary liner wall, shown in Figure 4-10 and Figure 4-11, is made up of a four plate course, including a bottom and top knuckle. The 3/8 in. thick secondary liner wall was welded up to the elevation just below the secondary top knuckle. Due to the curvature of the top knuckle and the requirement for access into the annulus during the primary tank construction, the top knuckle was installed after completion of all welding, inspection, stress relieving, and hydrostatic testing of the primary tank.

The concrete shell is $83 \mathrm{ft}$. outside

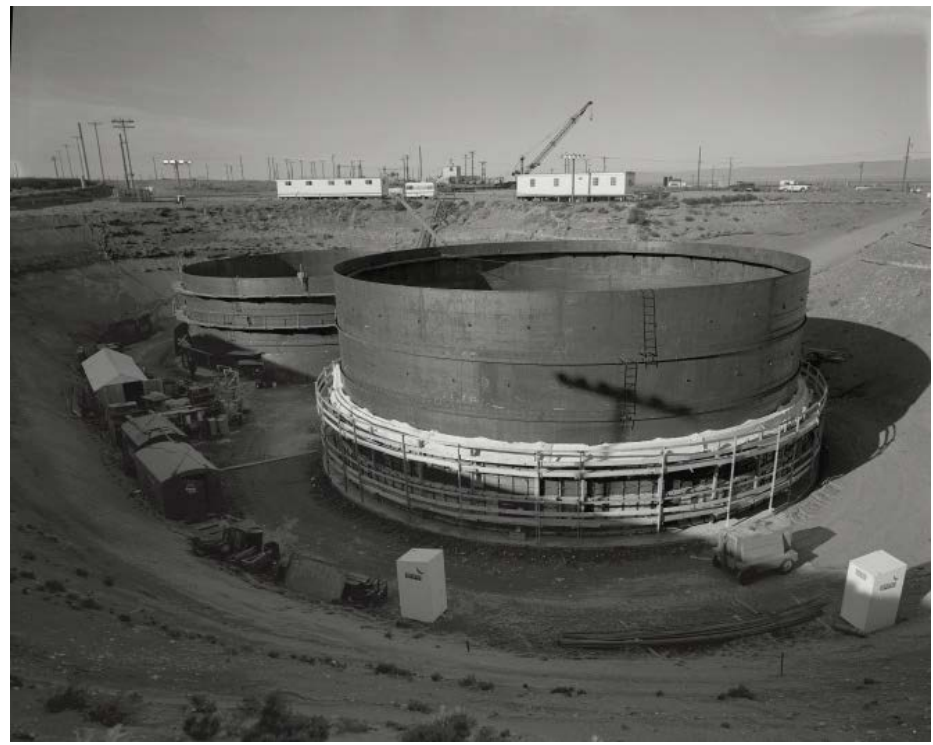

Figure 4-10. Overall View of Tank Construction - Looking West (56502-1 Photo) (Taken 11/22/71)

diameter, is $11 / 2 \mathrm{ft}$. thick, and rests on 
steel bearing plates supported by the tank foundation. The concrete shell was poured directly against the secondary liner (i.e., the secondary liner was used as a casting form for the concrete shell). The vertical portion of the reinforced concrete shell was poured in three courses. Each course was composed of concrete requiring a 28-day compressive strength of 3,000 psi. All three courses were completed prior to allowing backfill to begin. Figure 4-12 shows the site before backfilling occurred and Figure 4-13 shows it after partial backfilling.

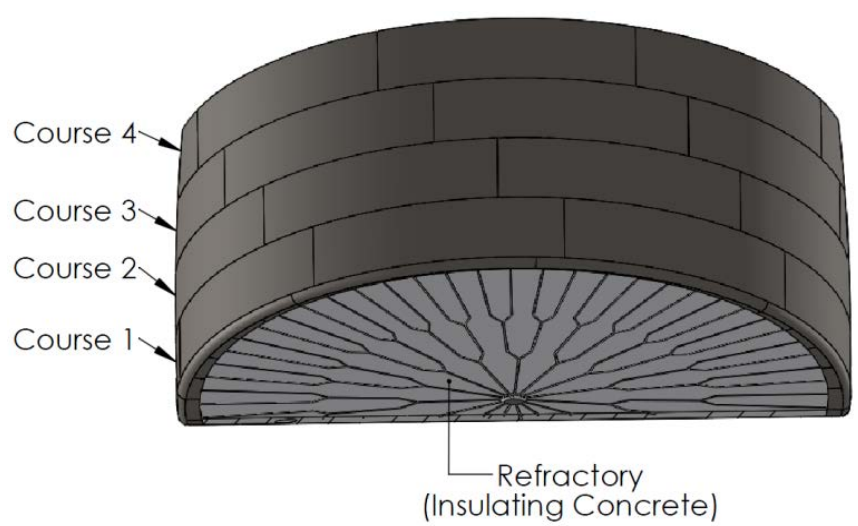

Figure 4-11. Cross-Section of Primary Tank and Refractory

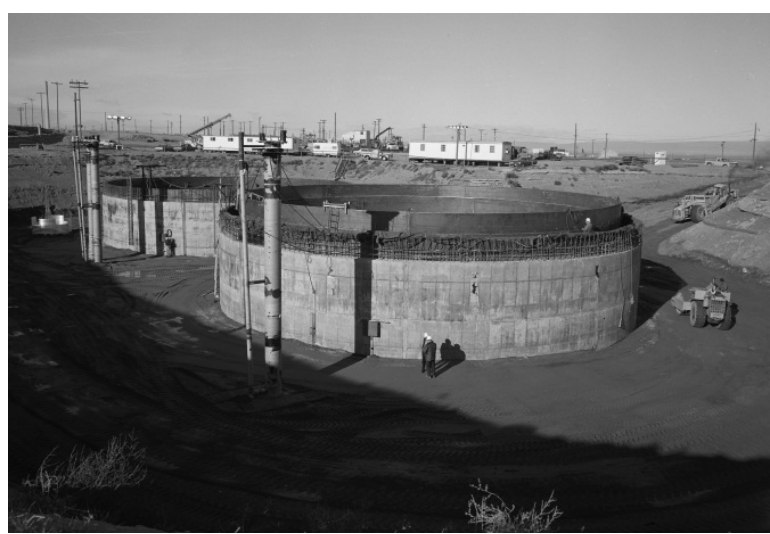

Figure 4-13. Backfilling Operations (56929-11 Photo) (Taken 1/21/72)

\subsection{PRIMARY TANK BOTTOM}

Following the pouring and curing of the refractory, work began on the primary tank bottom. The work to construct the primary tank bottoms of tanks AZ-101 and AZ-102 occurred between October 1971 and December 1971. In the case of tank AZ-102, some welds were inspected and repaired on the primary tank bottom through mid-January 1972 before they were considered acceptable.

The tank primary bottom is composed of primarily $1 / 2$ in. thick steel plates, increased from 3/8 in. used in the 241-AY tank farm, with the exceptions of the center $4 \mathrm{ft}$. diameter which is composed of

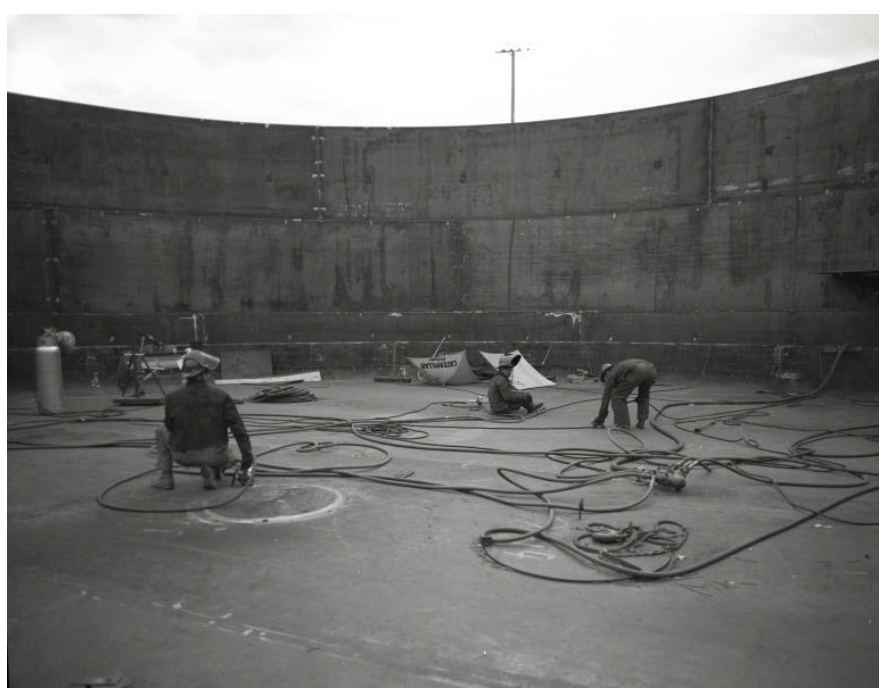

Figure 4-14. Welders Repairing Welds on the Primary Tank Bottom Sections Looking South, Tank AZ-101 (56272-6 Photo) (Taken 10/26/71) 
1 in. thick steel plate, and a 7/8 in. thick plate used for the bottom knuckle. A small vertical section of $7 / 8$ in. thick steel plate, referred to as the bottom transition plate, is also joined to the bottom knuckle. Similar to the secondary liner bottom, the welds on the top of the primary tank bottom were completed and the assembly was lifted up and placed on cribbing to allow workers to access the bottom of the plates. Figure 4-14 and Figure 4-15 show workers repairing welds on the primary tank bottom of tanks AZ-101 and AZ-102, respectively. For methods of inspection and acceptance of tank welds, see Table 5-3, in Section 5.1.

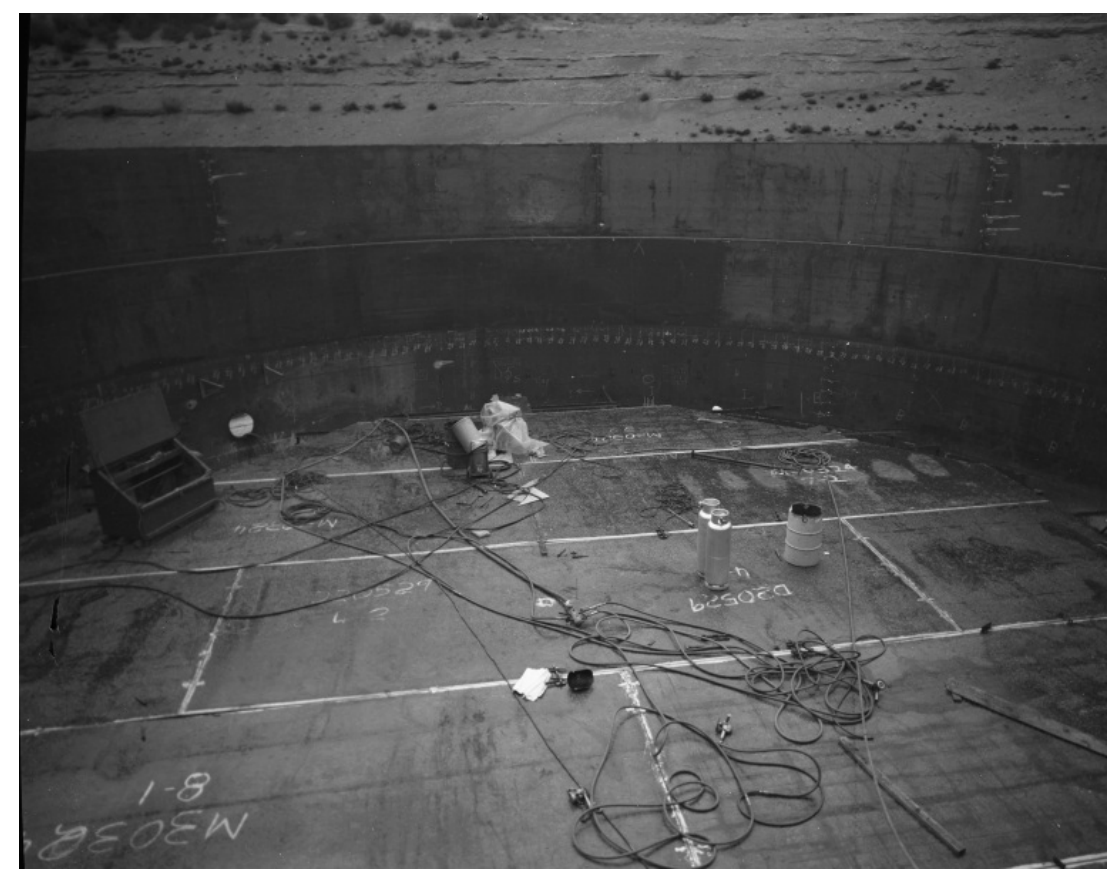

Figure 4-15 Weld Repairs in Progress on Tank AZ-102 - Looking South (56272-4 Photo) (Taken 10/26/71)

\subsection{PRIMARY TANK WALL AND TANK DOME}

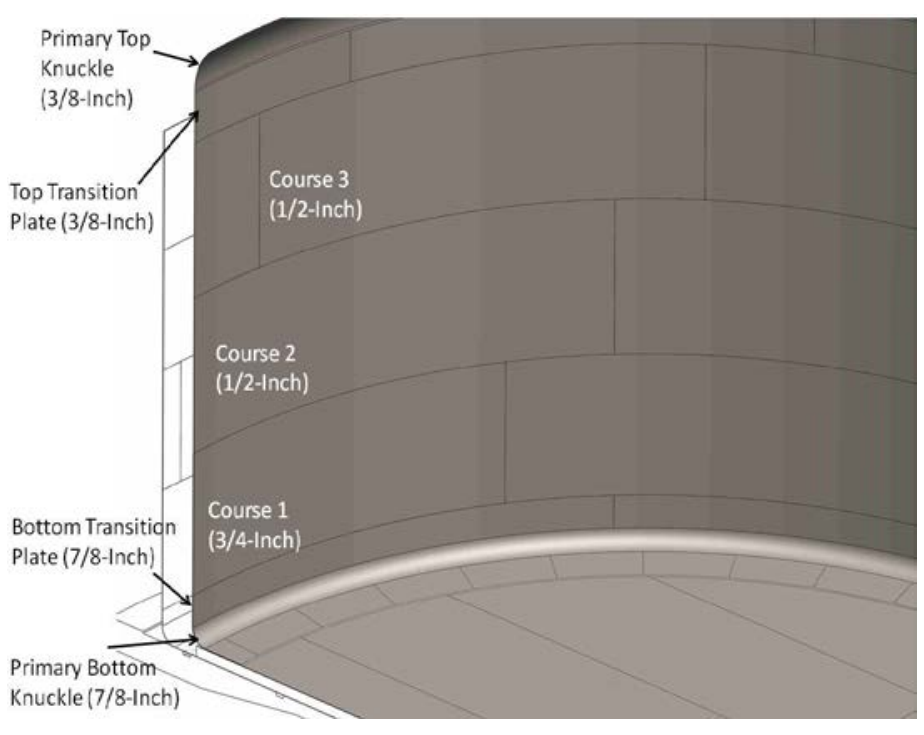

Figure 4-16. Cross-Section of Primary Tank
The primary tank measures $75 \mathrm{ft}$. in diameter (measured from the centerline of the steel plates composing the cylindrical section). While the vertical wall of the secondary liner is all 3/8 in. thick steel, the primary tank vertical wall plate thickness begins at a thickness of 7/8 in. and decreases as the elevation increases. Above the bottom knuckle and bottom transition plate, there are three main courses of plates as shown in Figure 4-16. Course 1 is 3/4 in. thick, the next two courses are $1 / 2 \mathrm{in}$. thick, and above the third course plate is a 3/8 in. thick plate referred to as the top transition plate. This 


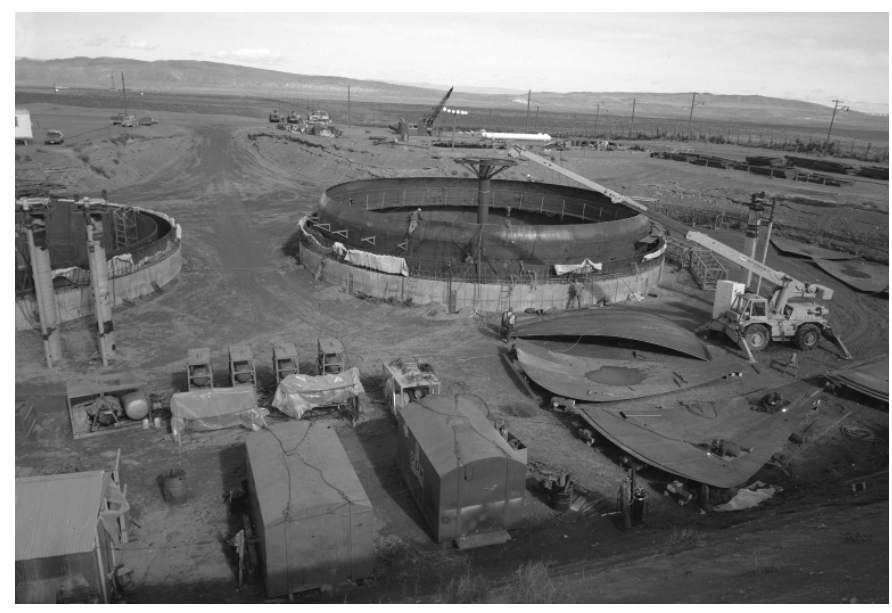

Figure 4-17. Construction Progress on Tank AZ-101 (57174-14 Photo) (Taken 2/22/72) top transition plate is butt welded to a $3 / 8$ in. thick primary top knuckle, which begins the elliptical shape of the steel tank dome.

To facilitate the installation of the tank dome plates, a temporary center support pole was installed. This pole provided a resting place for the tank dome plates for proper fit-up and welding. Several smaller dome sections were welded together on supports at grade level, before being lifted by a crane and welded in place. Figure 4-17 shows detail of the dome installation. After fabrication was complete, the center support pole was removed.

\subsection{PRIMARY TANK STRESS RELIEVING}

After installation of the risers, the tanks were prepped for post-weld stress relieving. Insulation was installed over the primary tank and in the annulus to protect the concrete foundation from high temperatures and to help regulate the heating of the primary tank. The refractory also protected the concrete foundation. The insulation used to retain heat and protect the concrete can be seen wrapped around the primary tank in 241AZ tank farm on May 25, 1972 (Figure 4-18, Figure 4-19, and Figure 4-20).

The requirements for stress relieving were in accordance with ASME Code, Section VIII (1971) which specified a holding temperature of $1100^{\circ} \mathrm{F}$ for 1 hour. In addition, the difference between maximum and minimum temperatures in the tank at any given time was required to be less than

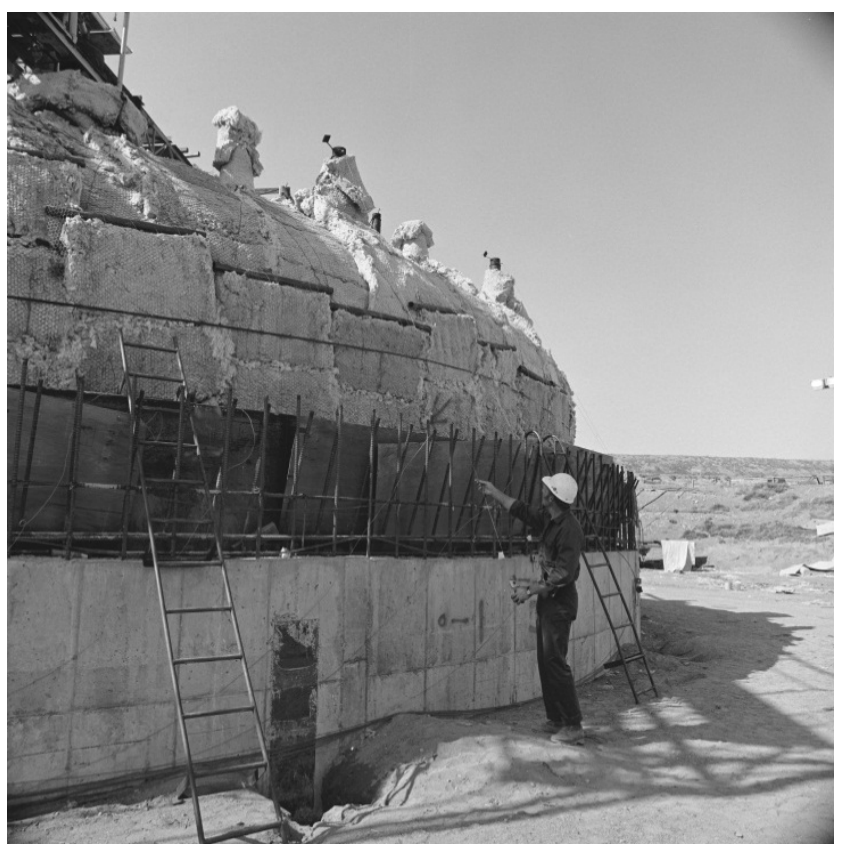

Figure 4-18. Insulation Installed and Held in Place with Wire Mesh on Tank AZ-102. (58073-4 Photo) (Taken 5/25/72) $200^{\circ} \mathrm{F}$. Thermocouples were installed throughout the tank to measure the temperature inside the tank. The thermocouples installed during the insulating refractory pour were used to monitor the progress of the tank post-weld stress relieving temperatures in the primary tank bottom. 
Section 16, "Stress Relieving," of HWS-8982, Specification for Primary and Secondary Steel Tanks Project HAP-647 Tank Farm Expansion 241-AZ Tank Farm, provided the following direction for stress relieving:

b. "Stress relieving shall be in accordance with Paragraph UCS-56, Section VIII, of the ASME Boiler and Pressure Vessel Code, except that:

1) With reference to Note 1, Table UCS-56 tabulation, the minimum allowable holding temperature shall be $1000^{\circ} \mathrm{F}$.

2) The rate of temperature rise and reduction between $600^{\circ} \mathrm{F}$ and $1000^{\circ} \mathrm{F}$ shall be no more than $100^{\circ} \mathrm{F}$, per hour.

3) The period of heating from $600^{\circ} \mathrm{F}$ to $1100^{\circ} \mathrm{F}$ shall consume no more than 12 hours.

4) During the heating-up period, above $600^{\circ} \mathrm{F}$, the temperature of all parts of the tank being heated shall be uniform with a maximum temperature differential at any time, between the highest and lowest temperature, of $200^{\circ} \mathrm{F}$."

Table 4-1. Post-Weld Stress Relieving in 241-AZ Tank Farm

\begin{tabular}{|c|c|c|}
\hline Event & AZ-101 & AZ-102 \\
\hline Burners Turned On & $\begin{array}{l}\text { 3:30 p.m. } \\
\text { April 19, } 1972\end{array}$ & $\begin{array}{c}\text { 5:08 p.m. } \\
\text { May 24, } 1972\end{array}$ \\
\hline $\begin{array}{l}\text { Completed Initial Hold } \\
\text { Time to Cure Refractory }\end{array}$ & Unknown & Unknown \\
\hline $\begin{array}{l}\text { Completed Final Hold } \\
\text { Time for Post-Weld Stress } \\
\text { Relief }\end{array}$ & $\begin{array}{c}\text { 1:40 p.m. } \\
\text { April 20,1972 } \\
\text { Two Hour Hold at } \\
1050^{\circ} \mathrm{F}\end{array}$ & $\begin{array}{c}\text { 12:10 a.m. } \\
\text { May 26, } 1972 \\
\text { Three Hour Hold at } \\
1000^{\circ} \mathrm{F}\end{array}$ \\
\hline $\begin{array}{l}\text { All Thermocouples } \\
\text { Reading Below } 600^{\circ} \mathrm{F} \\
\text { Recorders Turned Off. }\end{array}$ & Unknown & Unknown \\
\hline
\end{tabular}

The heating occurred in several stages and key events were captured in a stress relieving log. Important entries from this log have been included in Appendix A.

\subsubsection{Tank AZ-101}

Following a previously unsuccessful attempt, official startup of the successful stress relieving on tank AZ-101 was at 3:30 p.m. on 4/19/1972 (see Section 5.7). The contractor (PDM) had 12 hours to raise the temperature of the tank to $600^{\circ} \mathrm{F}$. When the first thermocouple reached $600^{\circ} \mathrm{F}$, the lowest thermocouple was required to be at least $400^{\circ} \mathrm{F}$ to maintain the differential below the maximum $200^{\circ} \mathrm{F}$. Another 12 hour stage would follow when the lowest thermocouple reached $600^{\circ} \mathrm{F}$ to then elevate the temperature to $1100^{\circ} \mathrm{F}$. At 7:30 p.m., the highest reading was $500^{\circ} \mathrm{F}$ and the lowest was $300^{\circ} \mathrm{F}$. PDM began trying to reduce the differential. At 11:00 a.m. on 
4/20/1972, PDM started the 3 hour hold with the lowest thermocouple at $1000^{\circ} \mathrm{F}$; however, the tank continued to heat and, at 11:40 a.m., the lowest thermocouple temperature reached $1050^{\circ} \mathrm{F}$. With the increased temperature of $1050^{\circ} \mathrm{F}$, a reduced hold time of 2 hours was allowed per Table UCS-56, Note 1, ASME Section VIII ASME Boiler and Pressure Vessel Code. A 2 hour hold time was initiated at 11:40 a.m. and then terminated at 1:40 p.m., which began the cooling phase. Cooling rate for the first two hours was 40$70^{\circ} \mathrm{F}$ per hour.

\subsubsection{Tank AZ-102}

Official startup of stress relieving on tank AZ-102 was at 5:08 p.m. on 5/24/1972. At 8:00 p.m., all thermocouple temperatures were reading below $600^{\circ} \mathrm{F}$ and the average temperature reading in the Kaolite was over $250^{\circ} \mathrm{F}$. On $5 / 25 / 1972$ at 3:45 p.m., the maximum temperature was $600^{\circ} \mathrm{F}$ and the minimum temperature was $400^{\circ} \mathrm{F}$. By 10:10 p.m. on that same day, the maximum temperature reached $715^{\circ} \mathrm{F}$ with the minimum temperature at $520^{\circ} \mathrm{F}$. At midnight that night, the minimum temperature reached $600^{\circ} \mathrm{F}$ and the temperature was increased by $50-60^{\circ} \mathrm{F}$ per hour. The last thermocouple reached $1000^{\circ} \mathrm{F}$ at 9:10 a.m. on 5/26/1972 when the maximum temperature recorded was $1160^{\circ} \mathrm{F}$. The 3 hour hold time initiated at this time. At 12:10 p.m., cooling began, concluding the post-weld stress relieving operation on tank AZ-102.

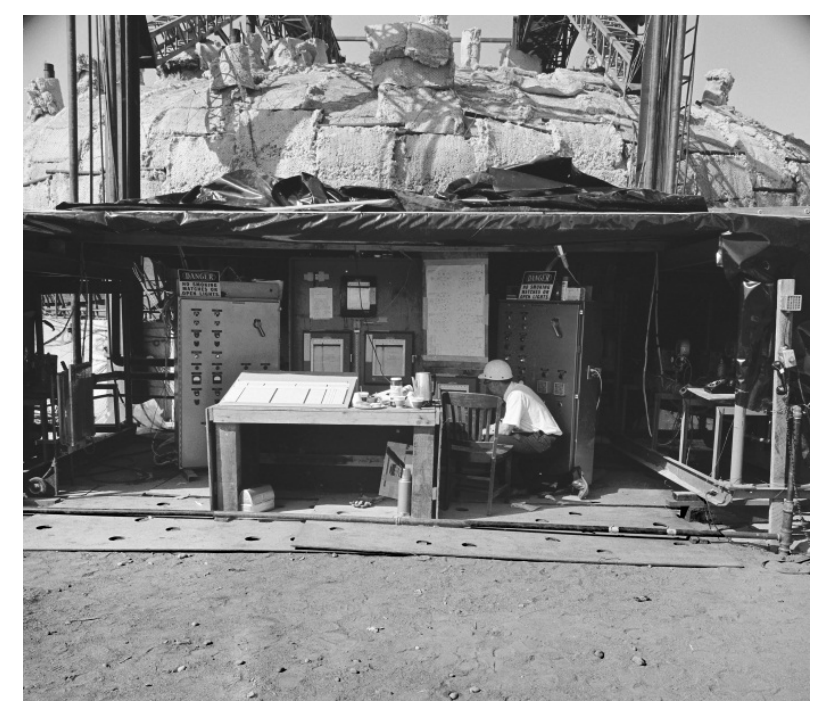

Figure 4-19. Worker Monitoring Chart

Recorders for PWHT of Tank AZ-102 (58073-1 Photo) (Taken 5/25/72)

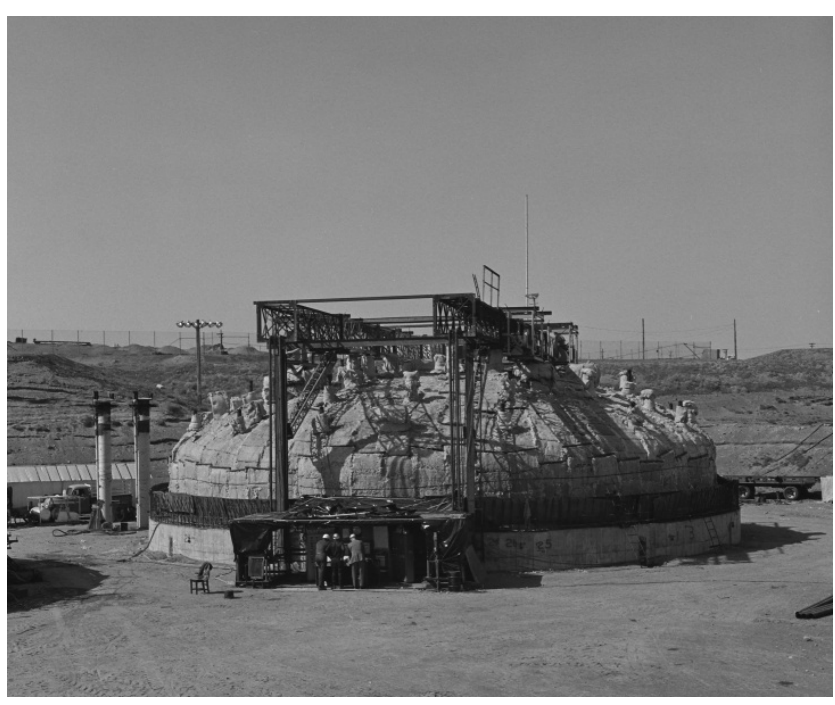

Figure 4-20. Overview of Tank AZ-102 PWHT Activities (58073-5 Photo) (Taken 5/25/72)

\subsection{PRIMARY TANK HYDROSTATIC TEST}

After completion of stress relieving, the heating equipment and temporary insulation were removed in preparation for hydrostatic testing to begin.

Section 18, "Hydrostatic Test," of HWS-8982, Specification for Primary and Secondary Steel Tanks Project HAP-647 Tank Farm Expansion 241-AZ Tank Farm, provided the following direction for hydrostatic testing: 
a. "After the tank has been stress relieved, a full hydrostatic test shall be applied to the primary tanks by filling with water to a depth of 39 feet from the bottom of the tank $( \pm 1$ inch). One of the vertical risers near the center of the tank dome shall be used for introduction of water. Air bleed ports shall be provided during the test. All accessible weld joints below the water level shall be coated with blue chalk. A preliminary hydrostatic test may be made, before stress relieving, at the Contractor's option.

b. The hydrostatic pressure shall be maintained for 24 hours.

c. Leak detection shall be by visual inspection of each welded joint previously coated with blue chalk."

Official startup of hydrostatic testing on tank AZ-101 was on 4/24/1972 with the start of tank filling. Prior to reaching the desired level for the hydrostatic test, the primary tank wall penetrations for product side fill lines were blanked. On 4/28/1972, the water level in the tank had reached 467 1/2 inches. The weld joints were chalked and then inspected on 5/1/1972 with leakage noted in five areas on a dome section. The water level was lowered and the areas were repaired.

Official startup of hydrostatic testing on tank AZ-102 was on 5/31/1972 with water being transferred from tank AZ-101 to tank AZ-102. No official fill height was noted in available documentation. Given that the water was transferred from tank AZ-101, the best assumption is that the fill height was also $4671 / 2$ inches. On 6/7/1972, chalking of the weld seams was started and they were inspected on 6/8/1972 and 6/9/1972. One minor repair was required on a penetration above the top knuckle.

\subsection{COMPLETE SECONDARY LINER AND TANK PENETRATIONS}

After completion of the hydrostatic test, the secondary liner top knuckle was installed and welded to the secondary liner vertical wall. The secondary liner is not welded to the primary tank. By design, a 1 in. maximum gap exists between the end of the secondary liner and the primary tank dome. To cover the existing gap, metal flashing was tack welded over it as shown in Figure 4-21 (H-2-67317, Tanks 101 \& 102 Section \& Details 241-AZ Tank Farm, Sheet 2, Detail 9). No photographs could be located for the period between May $25^{\text {th }}, 1972$ and June $20^{\text {th }}$, 1972, which is when the work referenced in this section occurred. The best available image of the completion of the secondary liner for tank AZ-101 is shown in Figure 4-22. 


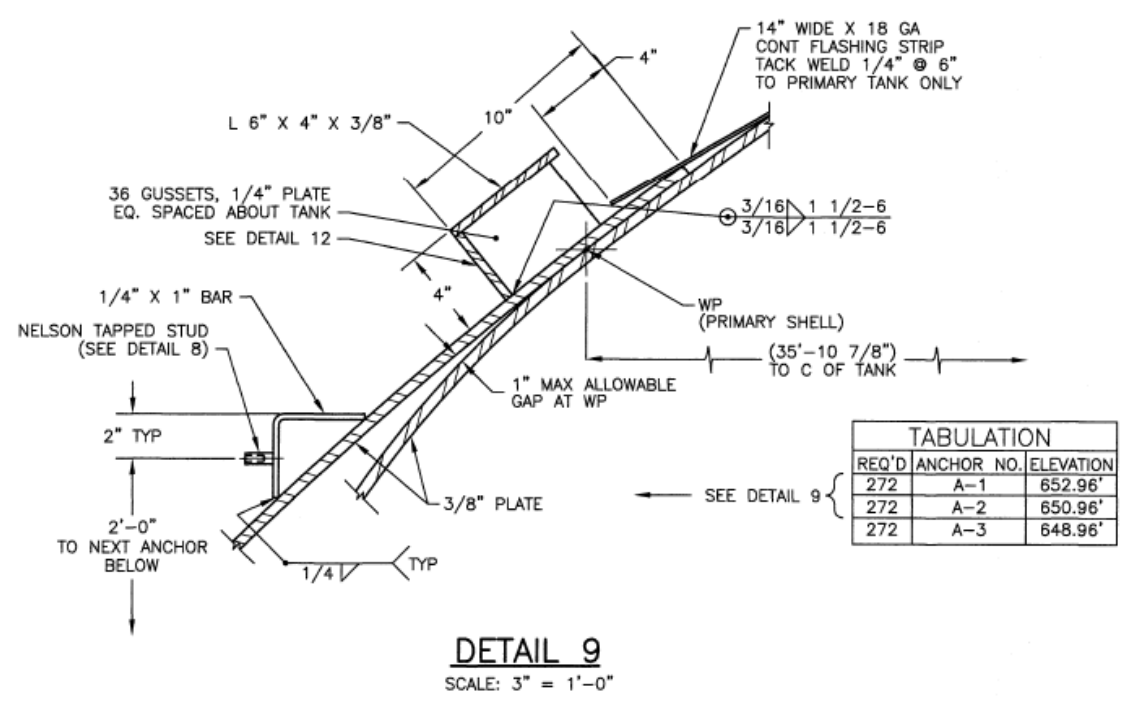

Figure 4-21. Detail 9 from Sheet 2 of Drawing H-2-67317 Showing the Intersection Between the Secondary Liner and Primary Tank Dome.

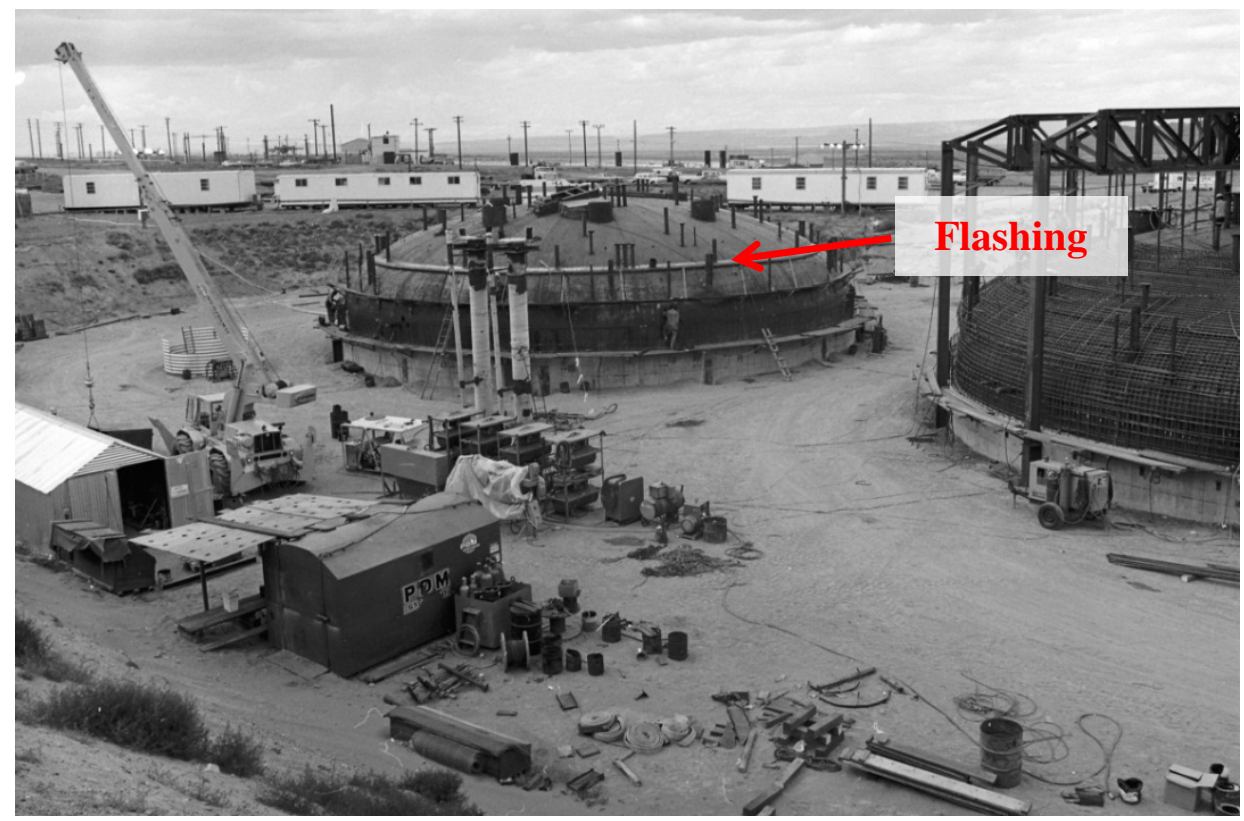

Figure 4-22. Overall View Looking Northwest at Tank AZ-102 in the Background (58288-34 Photo) (Taken 6/20/72)

During this time, penetrations into the secondary were made for the 4 inch diameter product side lines. Eight inch diameter pipe sleeves were installed in the secondary liner and an encasement bellows assembly was installed and bolted on to an 8 inch flanged sleeve penetration that previously installed on the primary tank sidewall during liner fabrication. Sealing between the primary product piping and encasement sleeves was provided by graphite impregnated asbestos packing. 
RPP-RPT-54818, Rev. 0

\subsection{CONCRETE DOME POUR}

Section 19, “Support of Tanks During Construction,” of HWS-8982, provided the following direction to support concrete pours:

a. "Tank supports shall be installed to maintain the tanks in the geometric shape shown on the drawings during the period while the wall and dome concrete is being placed. The secondary tanks will be used as the inside form for the concrete walls.

b. Concrete and concrete reinforcing steel will be furnished and placed by another contractor. Placement of concrete will be limited to a rate of not more than 2 feet in elevation per hour from the bottom or the wall to a point 2 feet above the tangent line of the done. Concrete in the haunch area, to the construction joint approximately 9 feet in from the outer wall form, will be placed at a rate not greater than one foot in elevation per hour. After concrete in the haunch area has cured a minimum of 3 days, concrete in the remainder of the dome will be placed in one continuous pour. The following are the wet concrete and live loads to be imposed on the tank:

Within Radius of Tank Center (ft) $\quad$ Load (lb. per sq. ft)

$\begin{array}{cc}0^{\prime}-25^{\prime} & 375 \\ 25^{\prime}-37^{\prime} & 450 \\ 37^{\prime}-40^{\prime} & 450 \text { at 37' radius to } 1,100 \text { at } 40^{\prime} \text { radius } \\ \text { Tank Wall } & 600\end{array}$

c. High-early-strength cement will be used in concrete above the tangent line of the tank domes to permit earlier access to tank interiors and completion of tank appurtenances. Concrete will have a slump of not more than 4 inches at the time of placement and a minimum compressive strength of 3000 psi in 28 days.

d. Shoring shall be of such design and construction that when the dome concrete is placed that no additional load will be placed on the shell of the primary tank.

e. Tank dome supports shall remain in place a minimum of 7 days after completion of the final placement of concrete in the tank dome, except that the center support shall remain in place 14 days.

f. The floor of the primary tank shall be covered with 5/8 inch plywood or one inch thick lumber to prevent the accidental re-concentration of stresses removed during stress relief. Dome support columns shall be designed to rest on blocks or heavy timbers which will aid in distributing the load."

After review of the logs and photographs, it was concluded that instead of using internal dome supports and shoring to support the dome, a large overhead truss system was utilized to support the tank dome from above during concrete pouring. This truss system was installed on tank AZ101 as hydrostatic testing was completed in early June 1972. A significant amount of structural rebar was installed around the tank prior to pouring the concrete. The rebar was used to reinforce the concrete and was being installed on both tanks AZ-101 and AZ-102 in late June 1972. In Figure 4-23, the crew is installing rebar in the dome region while concrete forms are in 
place on tank AZ-101 and the overhead truss system is visible. In addition to the truss support, during the concrete pour, air pressure was applied to the primary tank to provide additional support.

On 7/6/1972 at 8:20AM, dome pouring on tank AZ-101 began. The logbook entry of 7/17/1972 stated:

Confirmed with a telecon with D. Lien that the truss assembly could be removed if:

a. The Air Pressure was maintained.

b. A cylinder test would show 2000 psi minimum after 3 days.

Two test cylinders broke at 2100+ and 2300+ psi on 7/17/1972, meeting the 2000 psi requirement. With air pressure in the tank maintained, they then removed the truss system and it was then moved and installed on tank AZ-102.

On 7/31/1972, the haunch was poured for tank AZ-102. The dome is shown being prepared with reinforcing steel on $8 / 3 / 72$ in Figure $4-24$. The dome pour took place on 8/4/72. Two test cylinders broke at $2100+$ psi on $8 / 8 / 1972$, meeting the 2000 psi requirement. With air pressure in the tank maintained, the truss system was removed, concluding dome pouring in the 241-AZ tank farm. The completed concrete dome is shown in Figure 4-25, taken on 8/22/1972.

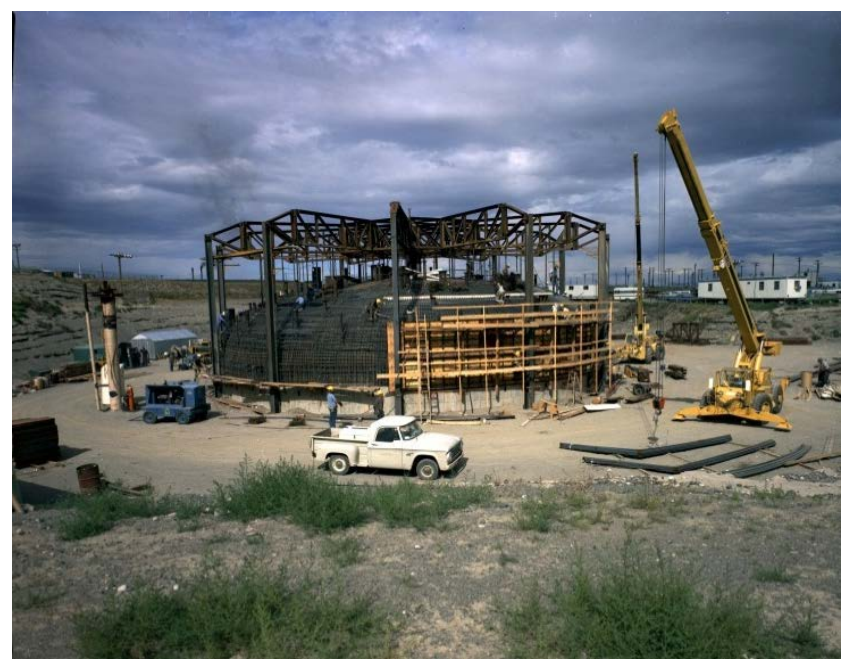

Figure 4-23. Tank AZ-101 Reinforcing Steel and Concrete Forms Being Placed on Tank AZ-101 (58324-2cn Photo) (Taken 6/23/72)

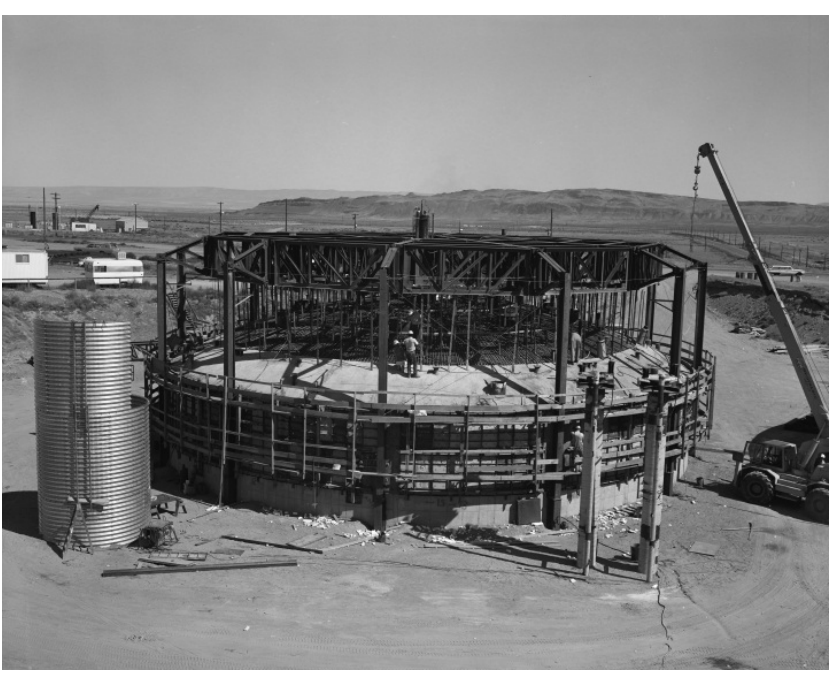

Figure 4-24. Tank AZ-102 Haunch and Dome Concrete Pour Progress, Showing Forms and Truss System (58580-2 Photo) (Taken 8/3/72) 


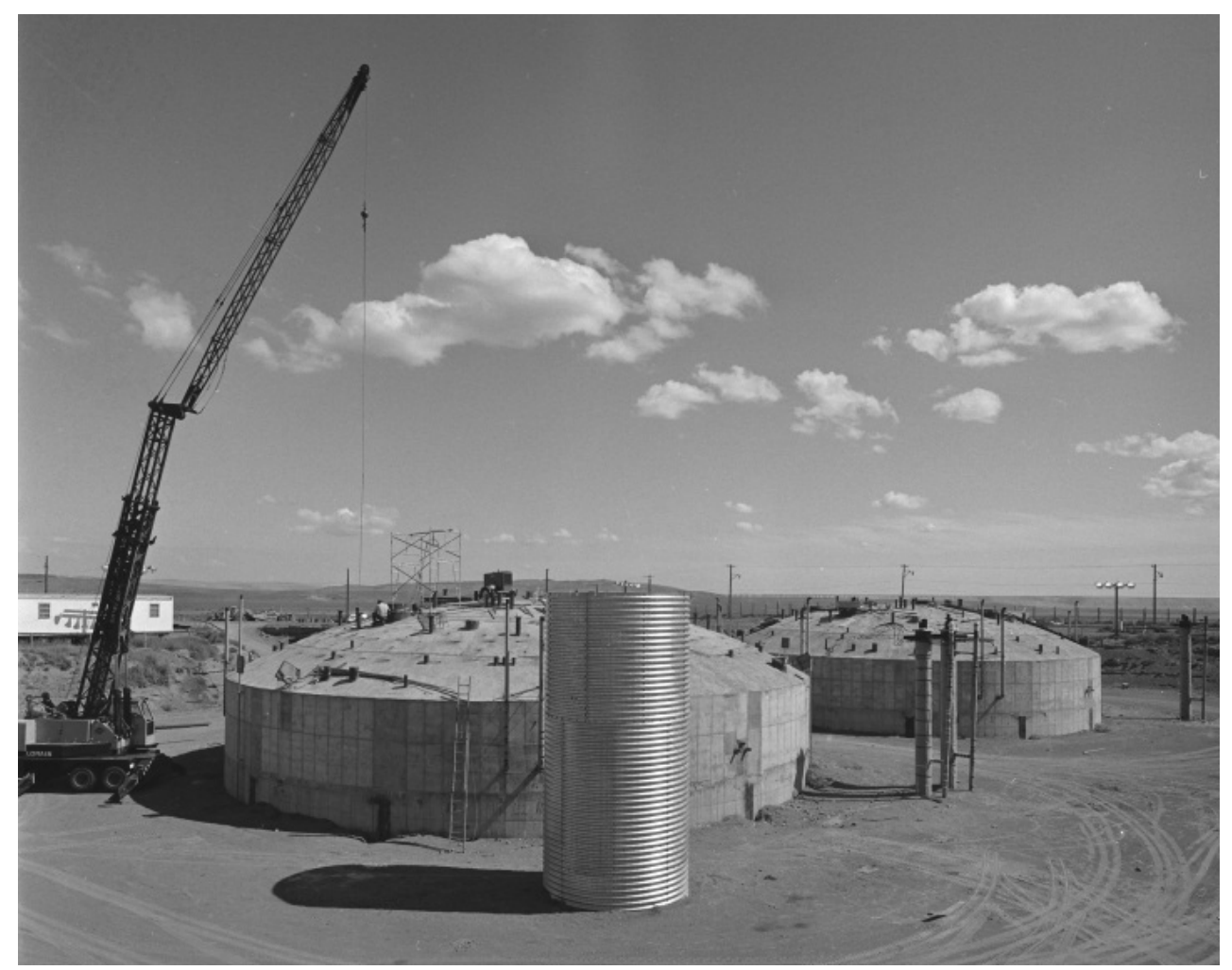

Figure 4-25. Overall View of 241-AZ Tank Farm Following Concrete Dome Completion (58744-40 Photo) (Taken 8/22/72)

\subsection{TANK APPURTENANCES}

After completing the concrete pours, the tank dome support truss system was removed. The equipment to be placed on the interior of the secondary liner and primary tank was then installed, including the tank air lift circulators, thermocouples, steam coil, and drop legs for the drain lines from the annulus pump pit and leak detection pump pit. These pieces of equipment were welded to the existing penetrations that had previously been installed on the tank dome prior to the tank stress relief. Figure 4-26 shows the in-tank equipment installed in tank AZ-102.

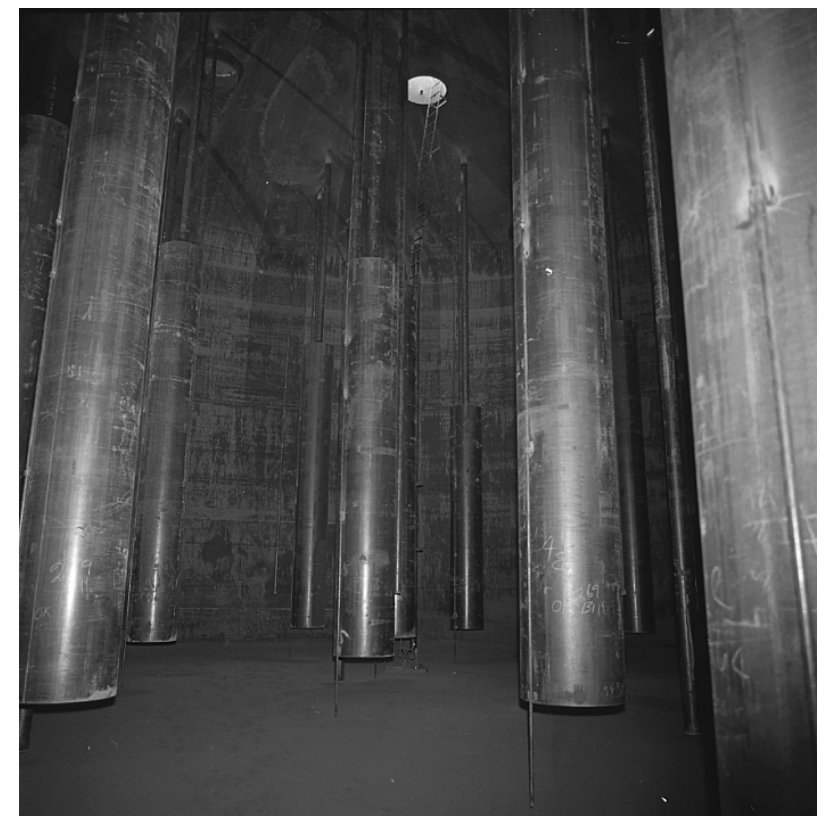

Figure 4-26. Looking at Completed Internals of Tank AZ-102 (58994-2 Photo) (Taken 9/20/72) 


\subsection{CONSTRUCTION ISSUES}

This section provides a detailed view of the construction issues identified during the fabrication of tanks AZ-101 and AZ-102. This information has been compiled from a review of the Quality Assurance (QA) daily logbooks, inspection sheets, memos, drawings, photos, construction records, and post-construction reports. The focus of this review was the secondary liner and primary tank bottom fabrication/testing, and the refractory.

\subsection{WELD REJECTION AND NON-DESTRUCTIVE EXAMINATION}

A quantitative comparison of weld acceptance on tanks AZ-101 and AZ-102 is shown in Table 5-1, "241-AZ Tank Farm Primary Tank Bottom Weld Comparison.” A similar comparison was completed and included within RPP-ASMT-53793, Tank 241-AY-102 Leak Assessment Report, for the 241-AY tank farm. Analysis of the tank AY-101 and AY-102 primary tank bottom radiography test diagrams (weld maps) was completed for a second time as a part of this extent of condition effort to ensure accuracy and consistency and is shown in Table 5-2. They are nearly identical to those previously tabulated except for the addition of the primary tank bottom center dollar plate in this report.

The overall weld rejection rates for the primary tank in tanks AZ-101 and AZ-102 were $14.5 \%$ and $6.3 \%$, respectively. The tank AY-102 overall weld rejection rate was $33.8 \%$. The maximum number of times a weld section was repaired in the 241-AY tank farm was four, with one weld section repaired four times in both tanks AY-101 and AY-102. In comparison, one weld section within tank AZ-101 was repaired five times and one weld section in tank AZ-102 was repaired three times before acceptance.

All welding was performed in accordance with approved procedures and by individuals qualified in accordance with Section IX, ASME Boiler and Pressure Vessel Code. All welds were examined and accepted using the methods described hereafter, and all welds were stress relieved during the post-weld stress relieving process.

See Appendix B for the weld maps for the complete primary tank and secondary liner of tanks AZ-101 and AZ-102. 
RPP-RPT-54818, Rev. 0

Table 5-1. 241-AZ Tank Farm Primary Tank Bottom Weld Comparison

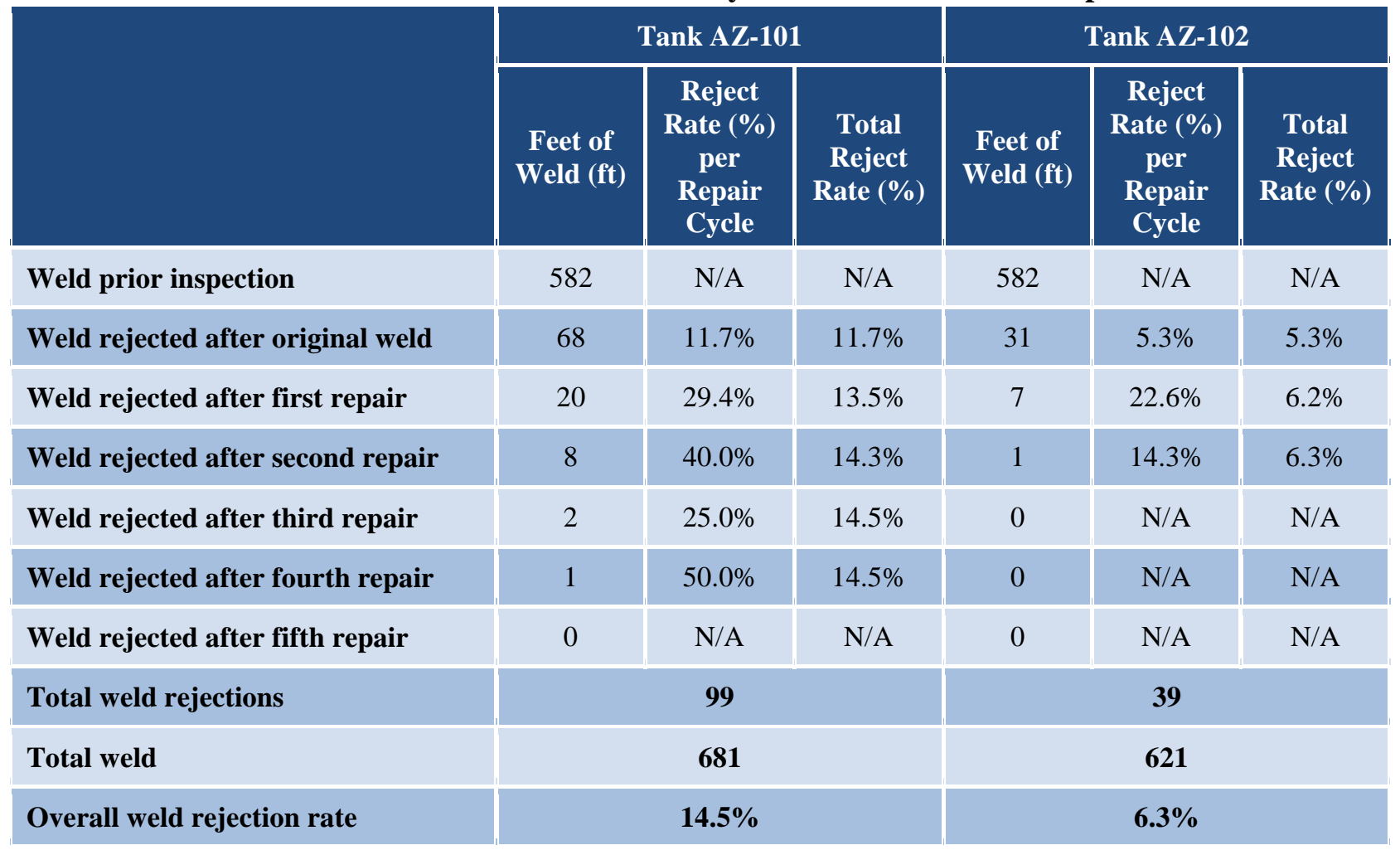

Table 5-2. 241-AY Tank Farm Primary Tank Bottom Weld Comparison
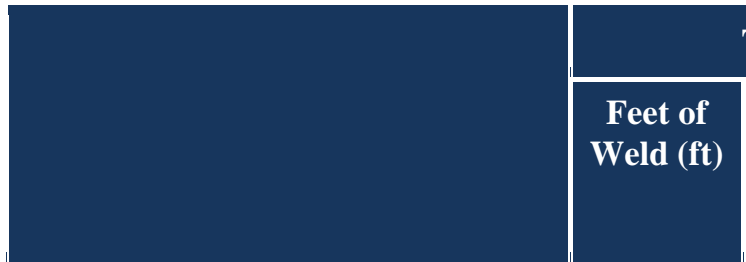

Tank AY-101

Tank AY-102

Weld prior inspection

672

Reject
Rate (\%)
per Repair
Cycle

Total
Reject
Rate (\%)

\begin{tabular}{|c|c|c|}
\hline \multicolumn{3}{|c|}{ Tank AY-102 } \\
\hline Feet of \\
Weld (ft) & $\begin{array}{c}\text { Reject } \\
\text { Rate (\%) } \\
\text { per Repair } \\
\text { Cycle }\end{array}$ & $\begin{array}{c}\text { Total } \\
\text { Reject } \\
\text { Rate (\%) }\end{array}$ \\
\hline
\end{tabular}

\section{Weld rejected after original weld}

N/A

N/A

673

N/A

N/A

Weld rejected after first repair

\section{Weld rejected after second repair}

Weld rejected after third repair

Weld rejected after fourth repair

Total weld rejections

67

$10.0 \%$

$10.0 \%$

229

$34.0 \%$

$34.0 \%$

7

\begin{tabular}{|c|c|}
\hline $10.4 \%$ & $10.0 \%$ \\
\hline $14.3 \%$ & $10.1 \%$ \\
\hline $100.0 \%$ & $10.2 \%$ \\
\hline N/A & N/A \\
\hline
\end{tabular}

Total weld

Overall weld rejection rate

76

86

$37.6 \%$

$34.9 \%$

\begin{tabular}{|l|l|}
\hline 1 \\
\hline 1
\end{tabular}

0

748

$10.2 \%$

\begin{tabular}{|c|c|}
\hline 27 & $31.4 \%$ \\
\hline 1 & $3.7 \%$ \\
\hline 0 & N/A \\
\hline & $\mathbf{3 4 3}$ \\
\hline & $\mathbf{1 0 1 6}$ \\
\hline & $\mathbf{3 3 . 8} \%$ \\
\hline
\end{tabular}


Throughout construction of the primary tank and the secondary liner, nondestructive examination (NDE) was required. The level of NDE varied between the primary tank and secondary liner and the elevation of the tank. The change in NDE relative to elevation was based on the planned use of the tank to contain waste up to a specific elevation. Table 5-3 provides a summary of the NDE used to ensure the pedigree of the primary tank and secondary liner. Further information on the NDE used can be found in the construction specification for the tank, HWS-8982, Specification for Primary and Secondary Steel Tanks Tank Farm Expansion 241-AZ Tank Farm.

Table 5-3. 241-AZ Tank Farm Nondestructive Examinations Used During Construction ${ }^{5}$

\begin{tabular}{|c|c|c|}
\hline & Primary Tank Inspections & Secondary Liner Inspections \\
\hline Tank Bottom & $\begin{array}{ll}\text { - } & 100 \% \text { radiography } \\
\text { - } & \text { Magnetic particle } \\
\text { - } & \text { Vacuum leak test } \\
\text { - } & 100 \% \text { visual } \\
\text { - } & \text { Hydrostatic leak test }\end{array}$ & $\begin{array}{l}\text { - } 100 \% \text { radiography } \\
\text { - } \text { Vacuum leak test } \\
\text { - } 100 \% \text { visual }\end{array}$ \\
\hline Bottom Knuckle & $\begin{array}{ll}\text { - } & 100 \% \text { radiography } \\
\text { - } & \text { Magnetic particle } \\
\text { - } & \text { Vacuum leak test } \\
\text { - } & \text { Hydrostatic leak test }\end{array}$ & $\begin{array}{l}\text { - } 100 \% \text { radiography } \\
\text { - } \quad \text { Vacuum leak test } \\
\text { - } 100 \% \text { visual }\end{array}$ \\
\hline Vertical Wall & $\begin{array}{l}\text { - } 100 \% \text { radiography up to } 422 \\
\text { in. } \\
\text { - } \text { Magnetic particle } \\
\text { - } 100 \% \text { visual } \\
\text { - } \text { Hydrostatic leak test to } 468 \text { in. } \\
\pm 1 \text { in. }\end{array}$ & $\begin{array}{l}\text { - } 100 \% \text { radiography up to } 381.5 \\
\text { in. } \\
\text { - } 100 \% \text { visual }\end{array}$ \\
\hline $\begin{array}{l}\text { Upper Knuckle } \\
\text { and Tank Dome }\end{array}$ & $\begin{array}{l}\text { - } 100 \% \text { Visual Inspection } \\
\text { Hydrostatic leak test of upper } \\
\text { knuckle and the horizontal } \\
\text { weld connecting the dome and } \\
\text { upper knuckle }\end{array}$ & - $100 \%$ Visual Inspection \\
\hline
\end{tabular}

\subsection{PLATE LAMINATIONS}

\subsubsection{Tank AZ-101}

Minor plate laminations found in the tank AZ-101 primary tank bottom by magnetic particle inspection were allowed to be removed by surface grinding provided that the depth did not exceed 1/16 in. A daily logbook recording from Tuesday, March 14, 1972 described the beginning of the issue and reads as follows:

\footnotetext{
${ }^{5}$ Tank NDE inspection reference documents: HWS-8982, H-2-67317, and Weld Maps (see Appendix B)
} 
“Weather: Sunny, $+60^{\circ} \mathrm{F}$, Wind at $3 \mathrm{mph}$

Indications revealed by Magnetic Particle Testing were being ground today, and some were determined to be relevant. Surface grinding resulted in discoloration of areas of the plate. These areas of varying widths could be literally "peeled off" the surface. Further grinding of those areas was discontinued at this time per my instructions to PDM, pending notification of other responsible personnel.

Subsequent evaluation of these areas revealed that the lamination type discontinuities could be removed by surface grinding to a depth not to exceed 1/16". The ground area was then re-tested and no indications noted. This information was revealed to E.F. Smith, who later informed me that if the discontinuities were of no more serious nature than those already detected, we would not be concerned with testing the shell rings. A. Short was also present during evaluation of these indications.

Preparations are now in progress to install the center plate of the 101 Tank Dome.

Welding continued on the pipe penetrations, and repair work on both primarys (sic).”

\subsubsection{Tank AZ-102}

Plate laminations were also seen in the primary tank AZ-102 upper shell ring plates in course four (SRP-4) during arc-gouging of welds and later detected by additional ultrasonic inspection. A total of six plates initially identified from two different heat and slab numbers (See WADCO Nondestructive test report 72-41, dated 3/17/1972, found in Appendix C, as App Figure C-1). The affected plates were four from heat 92B163, Slab 5-1 and two from heat 90B208, Slab 1-2. Plates from the same heats were used elsewhere in the tank, but not from the same slab.

Additional inspection of the six plates by WADCO was done again on 3/27/72 to more specific parameters, based on guidelines from ASME Boiler and Pressure Vessel Code Section V, SA435, (reference WADCO Nondestructive test report 72-41-1, dated 3/27/1972, copy in Appendix C as App Figure C-2). Based on these new criteria, laminations were now only reported in three of the plates from heat 92B163, Slab 5-1 and none in the two from heat 90B208, Slab 1-2.

The next day, on 3/28/1972, it was noted in the log:

"PDM was notified by John Slaughter that plate laminations should be repaired as indicated in PDM procedure RP-3. PDM responded by Arc-gouging a small section (3 inches long) adjacent the weld, which subsequently completely separated from the other half of the 3/8'plate. The lamination was still visible in the parent material (approx. 3/4 inch from the original weld edge...Additional areas were gouged, revealing similar conditions in the plate."

Pittsburgh-Des Moines was advised to not weld on laminated edges so work on the laminated plates was halted with recommendations made for replacement of four plates from heat 92B163, Slab 5-1. The plates from heat 90B208, slab 1-2 were not replaced and, although no documented 
RPP-RPT-54818, Rev. 0

basis was found, it is assumed that this decision was based on the fact that no laminations were found during the re-inspection. As the laminations were caused by spreading non-metallic contaminants in the slab rolling process or rolling the slab when too cold and allowing phase transformations during rolling, only the affected slab number would be suspect.

The four new plates for SRP-4 were delivered on 4/25/1972, and welded into place starting on 4/26/1972. A copy of the deficiency report is located in Appendix C as App Figure C-3.

\subsection{DEFECTS}

In the primary tank sidewall of tank AZ-101, a square groove from grinding was discovered after heat treatment and allowed to remain without repair. The groove is approximately 5-1/2 in. long by 3/16 in. wide by 3/32 in. deep (see Figure 5-1 and App Figure C-4). The groove is in the weld where the lower knuckle is joined to course one (seam E-1 between weld footage 127'-0 to 127'6 " with north assigned as zero). The following is a chronology of the events leading to the recommended disposition to leave as is.

On July 13, 1972, a letter was written by J. H. Slaughter, Field Engineer for the Construction Management Division of the United States Atomic Energy Commission to J.M. Frame, President of Vitro Engineering. The letter addressed several findings of a recent audit that had occurred. This letter is located within Appendix C as App Figure C-5. Item 2 of the findings stated the following:

"An area about six inches long was found on the $E 1$ weld seam of tank \#101 that appeared to be ground out, and not replaced with weld metal. The deepest indentation thereon was 3/32 inches."

Fifteen days later on July 28, 1972, Edgar F. Smith, Project Engineer for Vitro Engineering, responded to the above statement in a letter included in Appendix C as App Figure C-6. The response was the following:

"With respect to the apparent grinding of the E-1 seam without replacement by weld metal, we find that this condition exists in a 5-1/4" length of the E-1 weld seam which joins the $3 / 4$ " shell plate to the $7 / 8$ " plate forming the vertical extension of the bottom knuckle. In this length there is an aggregate of approximately 2-1/2" inches of gouging adjacent to the 7/8" plate this deeper than the extended surface of the $3 / 4$ " plate. The deepest penetration is .020". Inasmuch as the tank has been stress relieved, it would be inappropriate to fill this gouge with weld metal at this time. However, the following corrective action will maintain the integrity of the tank and be within the parameters of allowable sharp gouge defects permitted under the specification:

The weld crown existing vertically above the gouge area should be ground flush with the surface of the $3 / 4$ " plate that constitutes the inner surface of the tank. Removal of any part of the $3 / 4$ " plate should be specifically prohibited. The edge of the $7 / 8$ " plate adjacent to the gouge should be tapered by grinding on a 1 to 4 ratio in a vertically downward direction. Removal of metal beyond the plane surface of the $3 / 4$ " plate that constitutes the 
inner surface of the tank should be prohibited. The same method and parameters for metal removal horizontally at the ends of the gouge should be employed. Recognizing that the tank has been stress relieved, extreme caution should be taken in implementing these procedures to avoid impact forces on the tank and creating any local high heat zones."

A letter written on August 24, 1972 by W.C. Armstrong, addresses the structural effects of the groove at seam E-1 of the AZ-101 primary tank (see App Figure C-7). This letter overrides the recommendation in the July $28^{\text {th }}$ letter to grind and taper down the $7 / 8$ in. plate to meet the groove and instead recommends that no corrective action be taken.

"The structural effect of the unrepaired weld grindout in the E-1 seam inside the 101-AZ primary tank has been investigated by our structural engineer F.R. Vollert, using the data of the geometry survey by Mr. A. Short, Vitro Engineering. As a result, it is considered that the grindout as it exists does not present a structural threat to the tank. The geometry of the grindout presents no stress riser condition, and a liquid penetrant test revealed no crack emanates from the grindout base. It is, therefore, recommended that no corrective action be attempted lest overgrinding result or the benefits of stress relieving be impaired by filler welding."

A day later on August $25^{\text {th }}$, a report was written to summarize the issue and provide a recommended disposition. This document is included in Appendix C as App Figure C-4 and stated the following to describe the deficiency:

"Weld seam E-1 on the inside of the Primary Tank 101 between weld footage 127'-0 to 127'-6" has a grind out approximately 5 1/2” long by 3/16" wide by 3/32" deep (at deepest point). Which was overlooked and not noticed until after Stress Relieving had been completed (sic)."

The disposition to the report was consistent with the August $25^{\text {th }}$ letter, discussed above, and simply recommended the following which was approved:

"Leave as is the groove caused by the grind out."

The final decision to leave the unrepaired weld grind out was based upon review by the ARCHO structural expert with conclusion that no structural threat to the tank existed. Liquid penetrant testing revealed that there was no crack emanating from the base of the groove and, as a matter of practicality, any repair attempted could impart additional stresses that would not have been relieved since post-weld stress relieving had already occurred. No similar condition was recorded for tank AZ-102. 


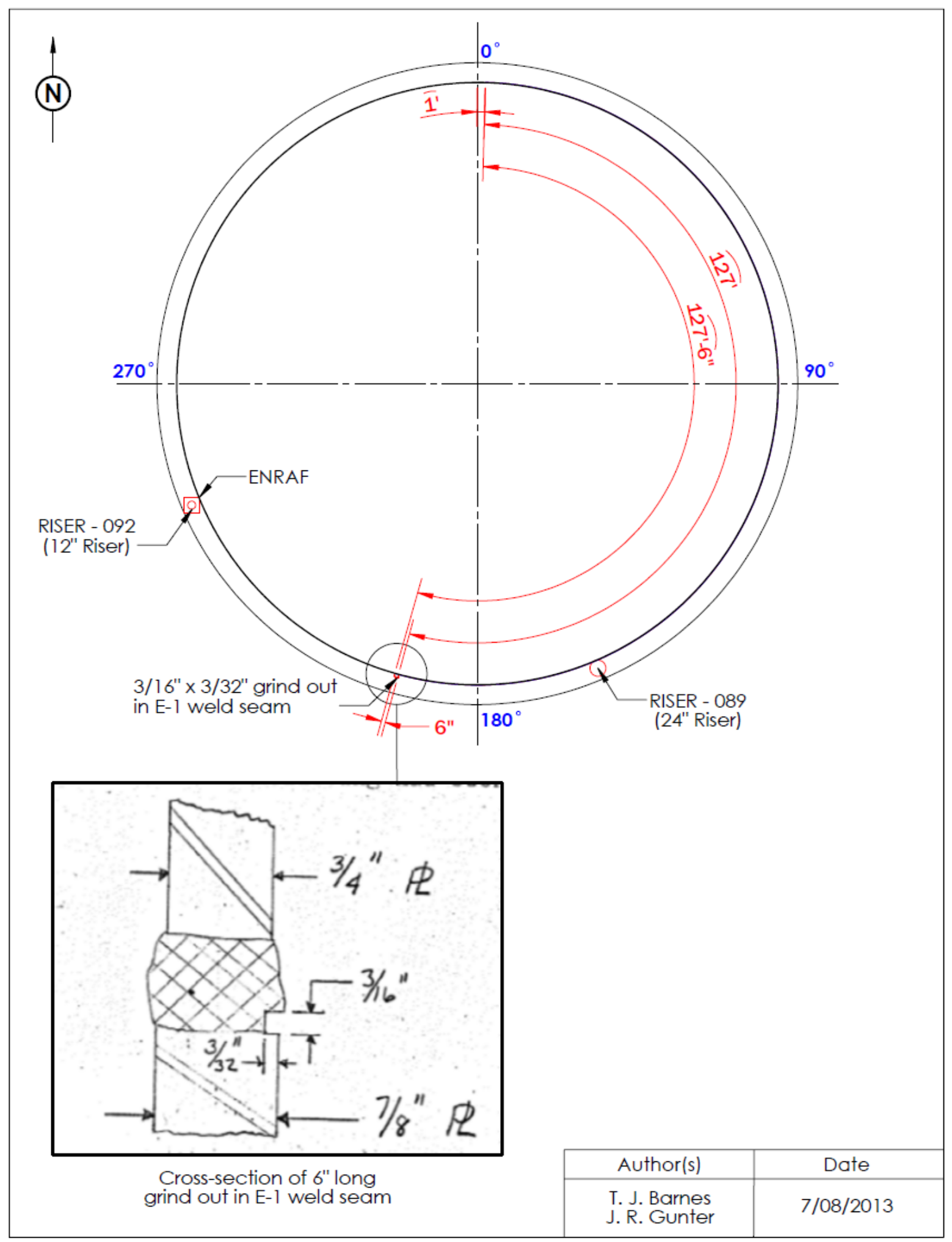

Figure 5-1. Tank AZ-101 Weld Grind Out in E-1 Seam 
RPP-RPT-54818, Rev. 0

\subsection{WELD REPAIRS FOLLOWING HEAT TREATMENT}

As stated within Section 4.8, there were five areas within tank AZ-101 and one area within tank AZ-102 where additional weld repair was required following hydrostatic testing. These repairs took place after hydrostatic testing and no additional stress relieving was done at these locations. It should be noted that these areas were all located above the maximum waste fill height of the tank.

\subsection{MINOR PITTING FROM HYDROSTATIC TEST WATER}

On July 13, 1972, a letter was written by J. H. Slaughter, Field Engineer for the Construction Management Division of the United States Atomic Energy Commission to J.M. Frame, President of Vitro Engineering. The letter addressed several findings of a recent audit that had occurred. This letter is located within Appendix C as App Figure C-5. Item 3 of the findings stated the following:

"The inside surfaces of the tanks have experienced pit corrosion."

Direction was provided in the letter to recommend a course of action to be taken to assure that the tanks maintain the desired degree of integrity.

Edgar F. Smith, Project Engineer for Vitro Engineering, responded to the above stated finding on July 28, 1972 in a letter included in Appendix C as App Figure C-6. The following was his response:

"As to pit corrosion on the inside surfaces of the tank, this, generally, is normal scaling rust action peculiar to the type of construction. In tank 101, however, a five foot depth of water was retained for a somewhat longer period than usual awaiting the time when it could be transferred to tank 102. In checking this area, it has been found that pitted areas generally have depths of .007" to .008"; the deepest pit being .010." Other rusted areas appear to have lesser pitting. It is opinioned that this scaling has not violated the desired degree of tank integrity and no further action is recommended."

On August 7, 1972, another letter was written from E.L. Moore to W.C. Armstrong, discussing the primary tank pitting (see App Figure C-8). The letter stated in part:

"Conditions in the tanks when filled with raw water during hydrostatic testing were ideal for promotion of pitting in carbon steel. This was quiescent water, undoubtedly containing chlorides, and breaks in the mill scale where rusting could occur. Pits can develop under this rust first as a result of differential aeration cells which then develop into passive-active cells. Hence, any crevice, such as under a rust deposit, is a place where the pit is likely to initiate. It is here that oxygen with respect to the immediate surrounding area creates an anodic area, and a differential aeration cell is formed. The loss of passivity in this region follows, creating a potential difference with respect to the large surrounding cathodic areas richer in oxygen. This is the passive-active cell. This condition promotes corrosion of the anodic areas. Through current flow, chloride ions in the water transfer into the pit, keeping the pit surface active. Pitting corrosion can be 
reduced and even eliminated by the addition of alkali to chloride containing water. This stifles pit growth because hydroxyl ions move into the pit more rapidly than chloride ions precipitating basis metal chlorides. Oxygen can again diffuse into the pit and restore passivity.

The removal of the mill scale from the inside surface of the primary tanks has been suggested as a means of reducing pitting corrosion. I feel that the benefit received would not be worth the expense of the sand blasting.

It is my understanding that the 102-AZ tank will be put in an emergency standby condition at some future date. This will mean filling with approximately five feet of water and maintaining a temperature of $180^{\circ} \mathrm{F}$. Rather than go to the expense of sand blasting, I would recommend that the water be adjusted to a $\mathrm{pH}$ of 10 or above by addition of $\mathrm{NaOH}$.

As a final note, some time ago I became interested in the extent of the passive-active cell set up between a carbon steel coupon covered with mill scale and one with the scale removed. Battelle ran a short test to measure the current generated when the two coupons were coupled in a $\mathrm{NaNO}_{3}$ solution adjusted to a $\mathrm{pH}$ of 9. It was found that within a few hours the current fell to zero, and the pitting corrosion ceased. This demonstrates the value of the hydroxyl ion in reducing pitting type corrosion."

Mr. Armstrong wrote a letter to Mr. J.H. Slaughter on August 24, 1972. It has been included in Appendix C as App Figure C-7. His comments on this subject matter were as follows:

"The very slight pits noted on the inside surfaces of the 101-AZ and 102-AZ primary tanks are considered by Mr. E.L. Moore, the Atlantic Richfield Hanford Company metallurgist, to have been caused by water during hydrostatic testing. The 101-AZ tank will be held in the empty condition which will not propagate pits. The 102-AZ tank will be held in a standby condition containing approximately five feet of water at a temperature of $180^{\circ} \mathrm{F}$. It is recommended that the water be maintained at a $\mathrm{pH} 10$ or above by the addition of $\mathrm{NaOH}$ which experience has shown to inhibit pitting."

The minor pitting that resulted from the extended storage of a raw water heel from hydrostatic testing was judged to present no threat to the tank integrity. Recommendations were made to prevent additional pitting by adding $\mathrm{NaOH}$ to a $\mathrm{pH}$ of 10 or greater if water was to be held in the tank before the addition of caustic tank waste. No detail of extended raw water contact during hydrostatic testing was discovered in tank AY-102 that would indicate the presence of pitting during construction. 
RPP-RPT-54818, Rev. 0

\subsection{REFRACTORY}

\subsubsection{Refractory Material Choice Concerns and Mitigation}

The refractory was specified to be either Kaolite 2000 or Kaolite 2200 LI, although the contractor was allowed to provide another material provided that it met all of the specification requirements found in HWS-8982, Specifications for Primary and Secondary Steel Tanks, Project HAP-647, Tank Farm Expansion, 241-AZ Farm. The specification also stipulated that the refractory meet a minimum compressive strength of 200 psi (relaxed to 130 psi during construction) and be certified compatible with the primary tank bottom and the simulated waste chemicals which was the same as specified for the 241-AY tank farm.

Kaolite 2000 was selected as the refractory material for 241-AZ tank farm. The best information available supporting the decision to use Kaolite 2000 is stated in a memo (Purex Tank Farm Expansion, 241-AZ Tanks Insulating Concrete-It's Purpose and Function, Smith (1971)):

"Samples of two castable refractories, Kaolite 2000 and Kaolite 2200 LI, furnished by Babcock and Wilcox were evaluated by Battelle Northwest Laboratories. The results of these tests (covered in separate reports) indicated that these materials met the functional, requirements and were compatible with the postulated chemical composition of waste liquids that might be conducted to the annulus in the grooves of the refractory. Accordingly, these two materials were listed in the specifications as being acceptable materials to meet the requirements."

A comprehensive review all DST refractories was performed in 2003 and documented in RPP19097, Evaluation of Insulating Concrete in Hanford Double-Shell Tanks. This reference included, as attachment 7, the test results for Kaolite 2000 (BNWL-B-56, Evaluation of Kaolite2000 Insulating Castable). The procedure for testing Kaolite 2000 was very similar to that used for testing Kaolite 2200-LI and Kaolite 20. For Kaolite 2000, however, the test results indicate that unfired samples immersed in simulated tank waste "decomposed" and were not subjected to compressive strength testing. No record has been found in the project records as to why the Kaolite 2000 was used in the 241-AZ tank farm despite this issue, but the rationale for the decision to use Kaolite 2000 seemed to rely on the top surface of the refractory being heated to $1100^{\circ} \mathrm{F}$ during primary tank heat treatment. BNWL-B-56 indicated that fired refractory would not decompose when exposed to waste.

\subsubsection{Installation Abnormalities}

During pouring of the refractory it was found that the irregular surface of the secondary liner bottom required the thickness to be increased above the design of 8 in. A report was written to address the deviation from design and is included in Appendix C as App Figure C-9. The deviation was described as follows:

"The depth of Kaolite 2000 will be increased due to the irregular surface of the secondary bottom. The depth will vary between 8 " and 10". The center elevation of the secondary bottom requires the depth of Kaolite to be approximately $91 \frac{1}{2 .}$." The increased depth will cause the primary tank to be higher in elevation than design calls for." 
The recommended disposition for this deviation was the following:

"The center sump will be welded to the secondary bottom with a temporary flat bar attached to the inside of the sump at the top to restrain the Kaolite during pouring (shown on sketch). The temporary flat bar will be removed after the Kaolite has been cured. Elevation readings on the surface of the Kaolite will be taken after pouring and the upper primary shell ring will be shortened accordingly (the difference between design thickness and actual)."

This increased thickness is apparent in Figure 4-9, which shows a worker pouring a section of refractory. On March 24, 1972, inspection photographs, such as Figure 5-2, were taken of the refractory and the over-thickness can be seen where several inches of material extend below the retainer ring. The primary tank bottom was installed at a higher elevation than originally planned as a result of this design variation, but does not create conditions for any potential failure mechanism.

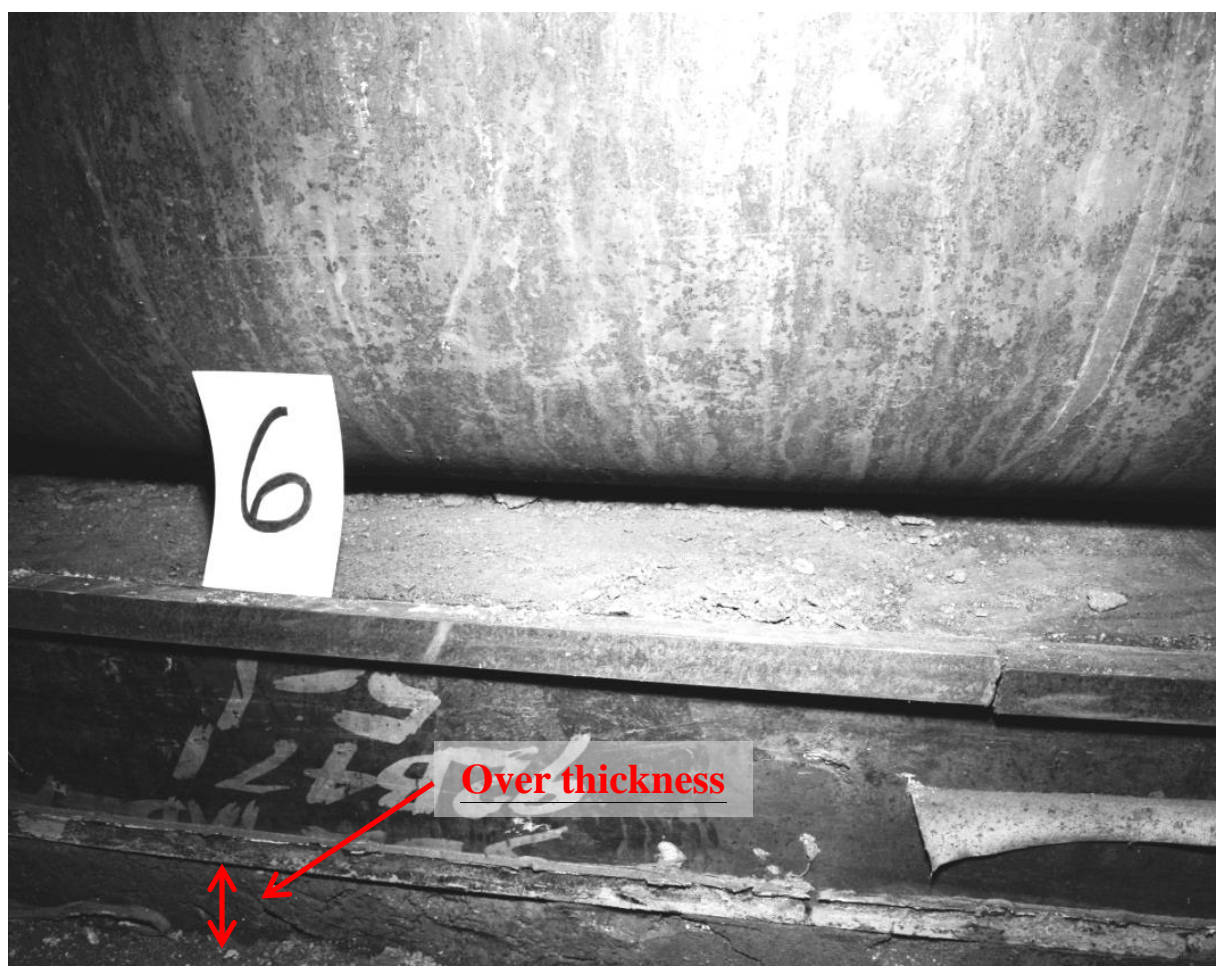

Figure 5-2. Refractory Over-Thickness (57482-20 Photo) (Taken 3/24/72)

During installation of the Kaolite retainer ring, shown in Figure 5-2 above, it was inadvertently installed upside down. A report was written and has been included in Appendix C as App Figure $\mathrm{C}-10$. This variation in design received a recommended disposition as follows:

"The holes in TK 101 for the air distributor piping were slotted out towards the secondary bottom plates to facilitate the maintaining of the proper relative elevation. $A$ 2" bar, per VITRO Engineering, will be welded to the back of the retainer band at the top 
to compensate for the removed steel below the band. (see below) The relative location of the pipe at the retaining band is as follows:"

\begin{tabular}{|c|c|c|}
\hline \multirow{2}{*}{ Location (TK 101) } & \multicolumn{2}{|c|}{ Distance to Centerline of Pipe } \\
\hline & From Secondary Floor & From Top of Kaolite \\
\hline$S E$ & 4” & $5 \%$ \\
\hline$N E$ & $43 / 4 ”$ & $4 \frac{1 / 4}{}$ \\
\hline$N W$ & $43 / 4 ”$ & $41 / 4 ”$ \\
\hline$S W$ & $41 / 2 ”$ & $4 ”$ \\
\hline
\end{tabular}

One of the four 2 in. bars that were installed to stabilize the air distribution piping through the retaining band in the modified configuration is shown in Figure 5-3.

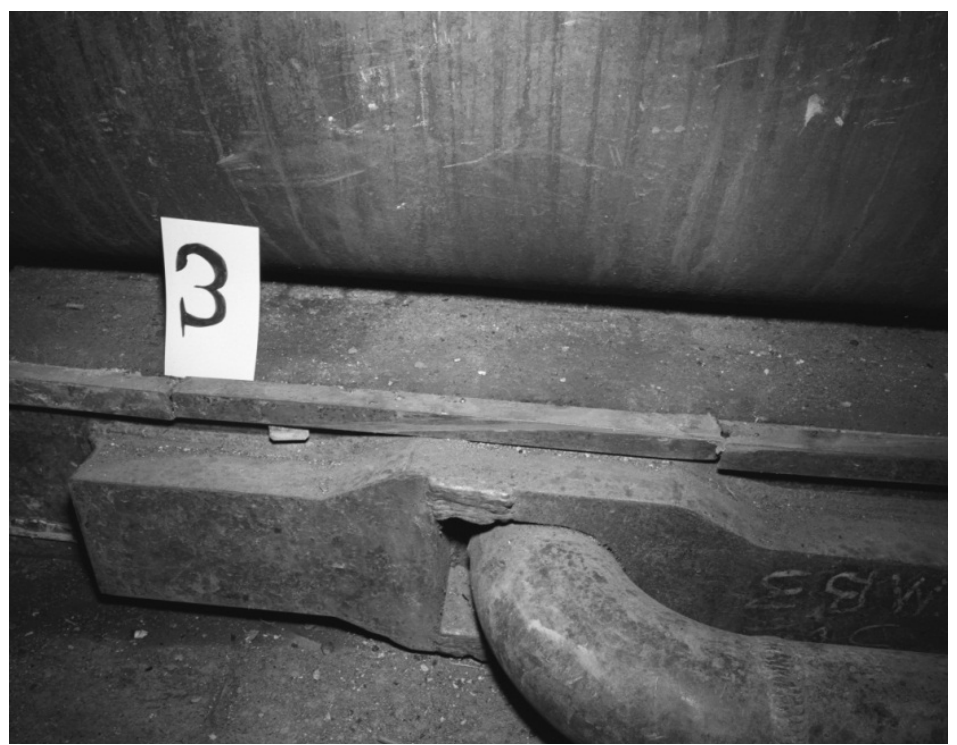

Figure 5-3. 2 in. Bar Welded to the Retainer Ring to Support Air Distribution Piping (57482-17 Photo) (Taken 3/24/72)

These modifications to the retainer ring and air distribution piping interface were deemed acceptable during construction and are not expected to have any impact on tank integrity.

Continuing with another abnormality of installation, the retaining ring was supposed to have slots cut into it where the thermocouple leads could run around the perimeter of the refractory and have adequate paths to allow for the air slots to drain into the annulus, given a leak event. The thermocouple slots were not cut as detailed during original installation and there were no unobstructed drainage pathways for the air slots. A report was written and has been included in Appendix C as App Figure C-11. This variation in design is described as follows:

“Per VITRO Drawing H-2-67295, Revision 0, a 1/4" wide by $21 \frac{1}{2}$ ” deep slot was to be cut where every thermocouple lead penetrates the Kaolite Retaining Band. These slots were not cut as detailed." 
As disposition to the variation, the following was recommended and later performed:

"A slot approximately 1/4" deep by 2" wide will be cut in the Kaolite Retaining Band to facilitate the thermocouple penetration. In order to provide drainage, a 1" diameter hole was cut in the Kaolite Retaining Band at the bottom of the air slots as shown on the attached sketch. The air slots selected for cutting of the holes will be at a different location than where the thermocouple leads penetrate the Kaolite Band, thus reducing the possibility of damaging the thermocouple lead."

These modifications to the retaining band served to provide adequate pathways to protect thermocouple wiring and for waste to drain to the annulus to reach leak detection equipment in a leak scenario. In Figure 5-4, shown below, one of the 1 in. diameter drainage holes is shown. Refer to Appendix C, App Figure C-11, for a diagram of the air slots where these holes were drilled. Regarding the thermocouple wiring penetrations, Figure 5-5 was the best available photo representing this variation, showing the thermocouple wiring coming out of the air slot in the refractory and entering into a protective metal channel along the top of the Kaolite retaining ring.

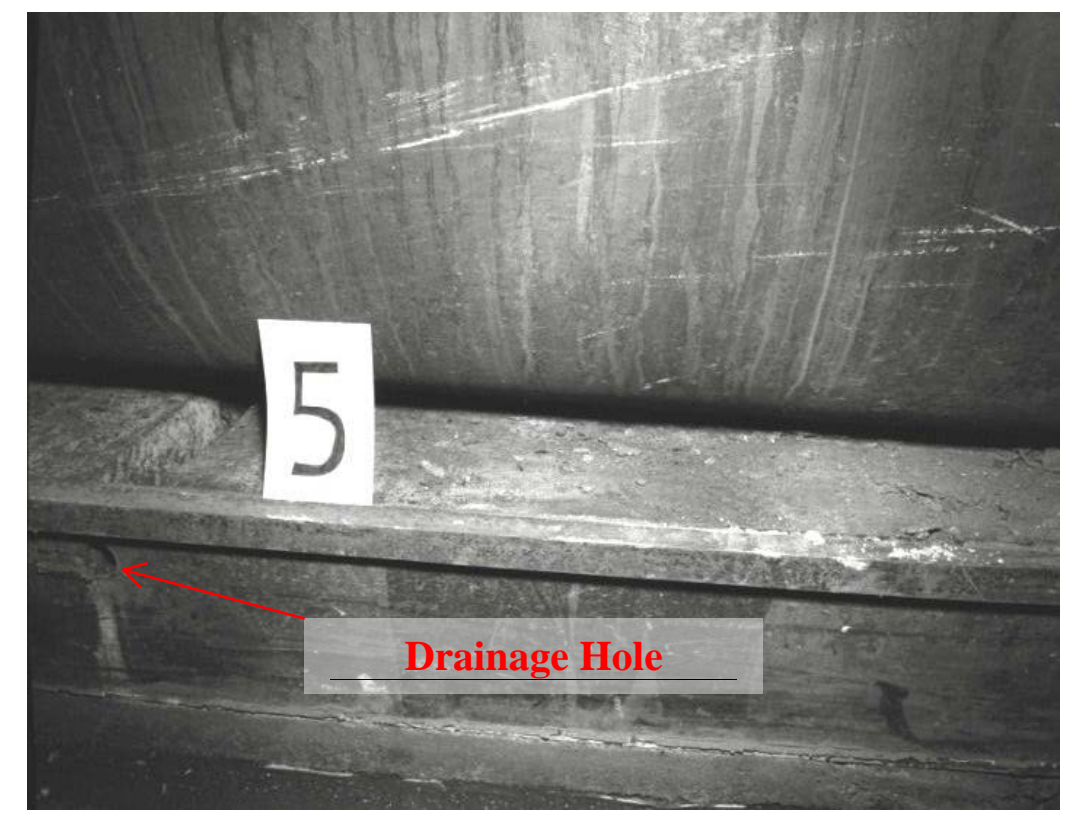

Figure 5-4. Kaolite Retaining Ring with 1 in. Drainage Hole Drilled at Air Channel 


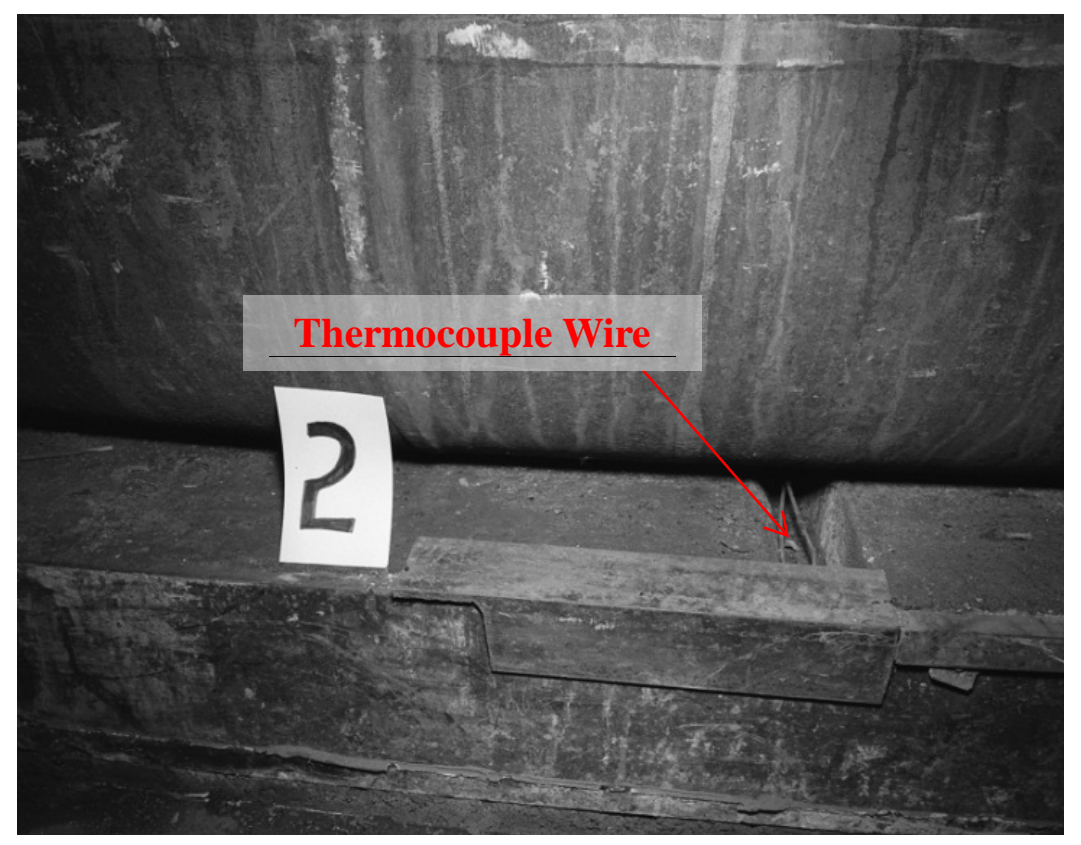

Figure 5-5. Thermocouple Wiring Protection. (57482-16 Photo) (Taken 3/24/72)

\subsubsection{Weather Protection}

On June 4, 1971, a letter was sent from Babcock \& Wilcox, the refractory supplier, to Willard Smith, containing written responses to several questions about refractory protection and quality. This document is included as App Figure C-12 in Appendix C. On the topic of freeze protection, the following detail is offered:

"There are two aspects to the question as to whether or not freezing and thawing conditions have any affect upon castable refractories. Generally speaking freezing and thawing of cured castables which contain only the water used in their placement will not be adversely affected. We will concede however that these same cured castables completely saturated by additional quantities of water are subject to deterioration as a result of freezing and thawing."

Appendix A contains daily accounts of construction activities. Those relevant to refractory weather protection have been repeated here in Table 5-4. 
Table 5-4. Significant Refractory Weather Events from Appendix A (2 Pages)

\begin{tabular}{|c|c|c|c|}
\hline Reference & Date & Tank & Comments \\
\hline 64 & 9/1/1971 & 101 & 0.54 inches of rain, a number of kaolite bags not protected and were wet. \\
\hline 77 & 9/15/1971 & 101 & $\begin{array}{l}\text { Temperature last night in tent was } 50^{\circ} \mathrm{F} \text {, discussion of using heaters. Air } \\
\text { pipe being placed. }\end{array}$ \\
\hline 80 & 9/16/1971 & 101 & $\begin{array}{l}\text { Wind gust tore canvas tent, pouring section 14, chipping kaolite from center } \\
\text { pan. }\end{array}$ \\
\hline 81 & 9/17/1971 & 101 & $\begin{array}{l}\text { TK } 101 \text { kaolite completed. Battelle photographer onsite. Some cracks 1" } \\
\text { deep being repaired. Heaters and temp recorder being setup. }\end{array}$ \\
\hline 84 & 9/20/1971 & 101 & $\begin{array}{l}\text { Recorded low Temp was } 62^{\circ} \mathrm{F} \text {, curing to be complete at } 4 \mathrm{pm} \text {. Core drilling } \\
\text { of kaolite on TK } 101 \text { completed. }\end{array}$ \\
\hline 94 & 9/27/1971 & 101 & $\begin{array}{l}\text { Curing protection removed from pourbacks and construction loads being } \\
\text { supported. }\end{array}$ \\
\hline 95 & 9/28/1971 & 102 & $\begin{array}{l}\text { Temp in } 102 \text { tent low of } 53 \mathrm{~F} \text {, limit is } 50 \mathrm{~F} \text { per procedure, more heaters to be } \\
\text { used. }\end{array}$ \\
\hline 97 & $9 / 28 / 1971$ & 102 & Rain squall, leak into tent on section 17. \\
\hline 98 & 9/29/1971 & 102 & Low temp in 102 tent was $52^{\circ} \mathrm{F}$, not enough kaolite is left to finish TK 102. \\
\hline 100 & 9/30/1971 & 102 & Low temp of $53^{\circ} \mathrm{F}$, will add heaters and additional kaolite located. \\
\hline 101 & 9/30/1971 & 102 & $\begin{array}{l}\text { Swing shift to be laid off due to lack of kaolite. Sections } 24 \text { and } 26 \\
\text { completed. Heating problems continue. }\end{array}$ \\
\hline 102 & $10 / 1 / 1971$ & 102 & Low temp was $79^{\circ} \mathrm{F}$, all heaters working. \\
\hline 103 & $10 / 4 / 1971$ & 102 & Semi with Kaolite 2000 arrived, requested it be protected. \\
\hline 104 & 10/5/1971 & 102 & $\begin{array}{l}\text { Section } 28 \text { badly cracked, to be chipped out and repaired, new kaolite not } \\
\text { protected, contractor problems noted. }\end{array}$ \\
\hline 107 & $10 / 8 / 1971$ & 102 & Curing of TK 102 kaolite completed, canvas tent removed. \\
\hline 120 & $11 / 1 / 1971$ & & $\begin{array}{l}\text { Water has collected in the annulus and soaked into the kaolite, responsibility } \\
\text { for kaolite protection not defined. }\end{array}$ \\
\hline 123 & $11 / 4 / 1971$ & 102 & Increasing width of air slots and cutting out areas for re-pouring. \\
\hline 125 & $11 / 5 / 1971$ & 102 & Kaolite cutouts keyed and repoured. Heat during cure is requested. \\
\hline 126 & $11 / 6 / 1971$ & 102 & All Kaolite repairs completed. \\
\hline 129 & $11 / 9 / 1971$ & 101 & Kaolite inspected and no problems noted in lowering of primary tank. \\
\hline 148 & $12 / 16 / 1971$ & & $\begin{array}{l}\text { Some damage may have occurred to kaolite due to freezing, ice formation in } \\
101 \text { primary bottom. }\end{array}$ \\
\hline 149 & $12 / 17 / 1971$ & 102 & Heaters placed under 102 bottom to avoid future freezing. \\
\hline 150 & $12 / 21 / 1971$ & 102 & Damaged kaolite being removed from TK 102 where necessary. \\
\hline 152 & $12 / 24 / 1971$ & & Kaolite temperature will be checked over holiday. \\
\hline
\end{tabular}


Table 5-4. Significant Refractory Weather Events from Appendix A (2 Pages)

\begin{tabular}{|c|c|c|c|}
\hline Reference & Date & Tank & Comments \\
\hline 154 & $12 / 29 / 1971$ & 102 & $\begin{array}{l}\text { Trusses being removed, requiring opening of tent, concern about maintaining } \\
\text { kaolite. }\end{array}$ \\
\hline 161 & $1 / 11 / 1972$ & & Winds to $60 \mathrm{mph}$. Many portions of canvas torn or missing. \\
\hline 165 & $1 / 14 / 1972$ & & Heat being maintained on both tanks and the caisson. \\
\hline 171 & $1 / 23 / 1972$ & 101 & $\begin{array}{l}\text { TK } 101 \text { was properly covered to prevent rain from entering the annulus, TK } \\
102 \text { was previously covered. }\end{array}$ \\
\hline 181 & $2 / 10 / 1972$ & 102 & $\begin{array}{l}\text { Fire discovered in TK } 102 \text {. Damage limited to canvas material used for } \\
\text { heating kaolite and wood scaffolding. Fire department thoroughly wetted } \\
\text { material. }\end{array}$ \\
\hline 183 & 2/13/1972 & 101 & Most of the tarps have blown off the 101 tank, but rain not expected. \\
\hline 184 & $2 / 14 / 1972$ & 101 & No longer required to cover TK 101 on routine basis. \\
\hline 186 & 2/18/1972 & & Heat being supplied to annulus to keep it dry as snow is falling. \\
\hline 196 & 3/1/1972 & & $\begin{array}{l}\text { Rain and snow. Notified G. Adolf to remove water from the annulus should } \\
\text { it become excessive. Heat should be turned on during rainy periods. }\end{array}$ \\
\hline 206 & 3/13/1972 & & $\begin{array}{l}\text { Heaters and plywood removed from the annulus, in view of the warm } \\
\text { temperatures and to facilitate removal of water from the annulus. }\end{array}$ \\
\hline
\end{tabular}

Referring to log entry reference number 148, dated 12/16/1971, it was believed that some of the discovered damage to the refractory in tank AZ-101 was due to freezing and ice formation. As a result of this discovery, and with the advice provided by Babcock and Wilcox to prevent saturation to avoid deterioration in mind, immediate efforts were undertaken to maintain the environment under the tent above $50^{\circ} \mathrm{F}$, prevent water intrusion, and dry it out should intrusion occur.

A memorandum was written on December 16, 1971 by E.F. Smith, confirming direction to protect the refractory with additional measures. This correspondence has been included in Appendix C as App Figure C-13 and states the following with reference to protection measures:

"Our telephone conversation at 3:30 pm, this date, is confirmed; you were directed to take immediate action (and implemented today) to protect Kaolite in Tank 102, as follows:

Kaolite is to be covered with "Visqueen", propped up by horses or by other suitable methods with space heaters placed above the Kaolite. The warm air should be circulated by fans or other means."

These steps are taken in the interest of removing excess moisture so that frost action will not damage the Kaolite. Upon removal of the excess moisture, protective measures should be taken to prevent additional moisture entering the Kaolite." 
Two additional pieces of correspondence discuss the discovered frost damage and resulting protection measures, both dated 12/20/1971. The first of the two was sent from E.S. Davis and is included as App Figure C-14 in Appendix C. It provides the following explanation of events:

"On 12/16/1971 while inspecting work being performed on kaolite in Tank 102, I noted that the outer edges of the kaolite contained frost crystals. Further investigation indicated that for a distance of approximately 10' from the outer edge toward the middle the surface of the kaolite was frozen. I picked up samples of the frosted material and placed them in a $72^{\circ}$ environment. After thawing, the samples appeared damp. Later I placed the samples in an oven and dried them out. There appeared to be no damage to the material.

I called John Slaughter, AEC, and advised him of these conditions. Mr. Slaughter came to the job site and arranged for sample cores to be made. I also advised Edgar Smith of the conditions and he arranged to get heat applied to the kaolite overnight.

At 8a.m., 12/17/1971, I inspected the kaolite again in Tank 102. There was no frost indication remaining along the outer edges of the kaolite. There were numerous areas where the kaolite, for depths varying from 1/16" to 1/4", was either mushy or brittle and flaky. This variation seemed to depend upon the amount of moisture in the material. In addition, there were areas along the outer edge that sounded hollow when tapped with a steel tool. The contractor was advised that these areas would have to be repaired."

E.S. Davis made note in the previous memorandum that he advised Edgar F. Smith (E.F. Smith) of the conditions and that he arranged overnight Kaolite heating. As evidence to this action, the second letter on 12/20/1971 was from E.F. Smith, confirmed the Kaolite protection measures. This letter has been added as App Figure C-15 in Appendix C. It states in part:

"Auxiliary heat has been provided in both tanks 101 and 102 to maintain temperatures above freezing and to drive out excess moisture from the Kaolite. Heat was applied in tank 102 on the evening of 12-16-71 (see reference memorandum); additional heaters were obtained off-site and were available for both tanks on 12-18-71. Satisfactory temperatures have been maintained since that time.

Preliminary information regarding freeze-thaw cycles of Kaolite containing excess moisture (see referenced memorandum) is confirmed. Several telephone conferences with Edward Dixon, who heads up Technical Research for Babcock \& Wilcox of Atlanta, Georgia, have pointed out that ice formation in fully saturated, light weight castables will break down the granular structure resulting in a loss of strength."

As the various log comments in Table 5-4 indicate, water retention within the tank and potential oversaturation of the Kaolite material presented several problems during construction. In general, the response to the deficiency was swift and effective. The application of heat and covering served to protect the refractory through the winter until post-weld stress relieving could take place in the spring of 1972. 
RPP-RPT-54818, Rev. 0

Some lessons learned from the 241-AY tank farm construction were incorporated into the design of the 241-AZ tank farm refractory slab and better efforts were made to keep the refractory dry after curing to protect from freeze damage. The 241-AZ tank farm refractory did not require major repair after stress relieving as occurred for tank AY-102.

\subsection{STRESS RELIEVING OF THE PRIMARY TANK}

The initial stress relief attempt of the tank AZ-101 primary tank began on April 7, 1972. On April 8, 1972, 4-12 shift workers experienced several difficulties, including large temperature differentials, inability to control heat spreading, and large overshoot of desired temperatures. Following those difficulties, the 12-8 shift of that same day attempted to increase the tank temperature above $600^{\circ} \mathrm{F}$, but could not do so in a controlled and even manner, violating specification requirement 16.0 b (4) of HWS-8982, "Specification for Primary and Secondary Steel Tanks Project HAP-647 Tank Farm Expansion 241-AZ Tank Farm,” which states:

"During the heating-up period, above $600^{\circ} \mathrm{F}$, the temperature of all parts of the tank being heated shall be uniform with a maximum temperature differential at any time between the highest and lowest temperature of $200^{\circ} \mathrm{F}$."

The process was stopped at this time and the temperature charts were taken for review. On April 12, 1972, a PDM Engineer provided modifications to the stress relieving procedure, which served as a recommended disposition to the related deficiency or variation report, shown in Appendix C as App Figure C-16. The description of the contract deviation/change/repair and recommended disposition are repeated here for clarity:

“Description of Contract Deviation/Change/Repair:

Stress Relieving attempt on April 7 thru 9 was not able to conform to specification requirements $\mathrm{HWS}$-8982 para $16.0 \mathrm{~b}$ (4).

Recommended Disposition:

Voluntarily stop Stress Relieving Operation and make the following modification or addition to Stress Relieving Equipment:

1. Stuff insulation in Kaolite slots and up tight against Lower Primary Knuckle.

2. Extend vent tubes down to within a foot of the bottom.

3. Extend burner tunnels down 15 feet approximately to the spring line of secondary tank.

4. Install a 10” OD (top) and 2'-0 OD (bottom) $60^{\circ}$ angle truncated cone, 12 inches below burner tunnels to deflect heat over to lower primary shell and knuckle.

5. Make Burner B operational.”

After these modifications were made, stress relieving was successfully performed as described in Section 4.7. 


\subsection{EVALUATION OF REFRACTORY AFTER HYDROSTATIC TEST}

No post-hydrostatic test refractory deficiencies were recorded. However, several photos of the refractory before heat treatment were found with captions indicating it being damp, soft, soggy, or mushy to a depth of 1/8 in., or having a crust that was 1/8 in. deep. Several of these photographs have been included within this section as Figure 5-6, Figure 5-7, and Figure 5-8. No records following heat treatment indicated that these conditions resulted in repair or replacement.

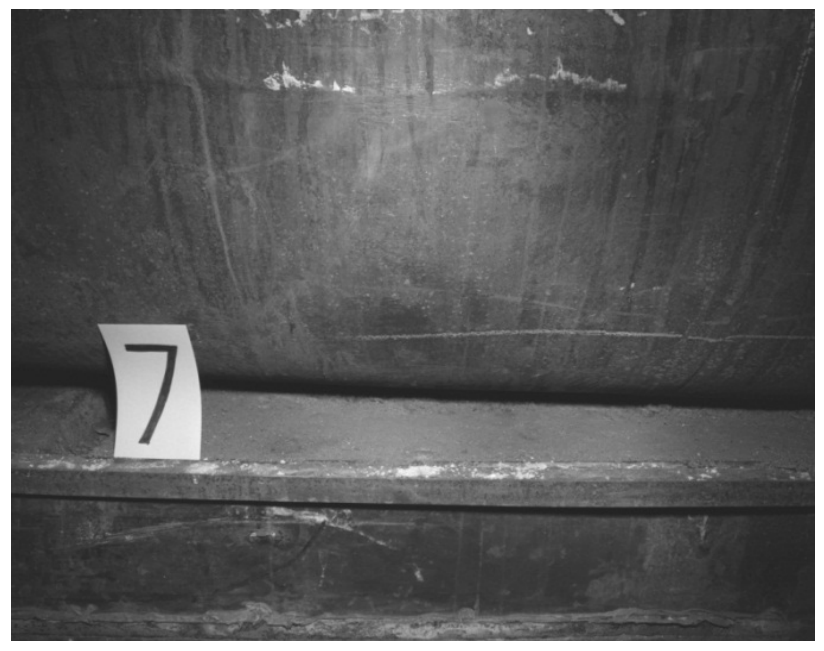

Figure 5-6. Kaolite Condition (Damp, Soft for 1/8 in. Depth) (57482-18 Photo) (Taken 3/24/72) 


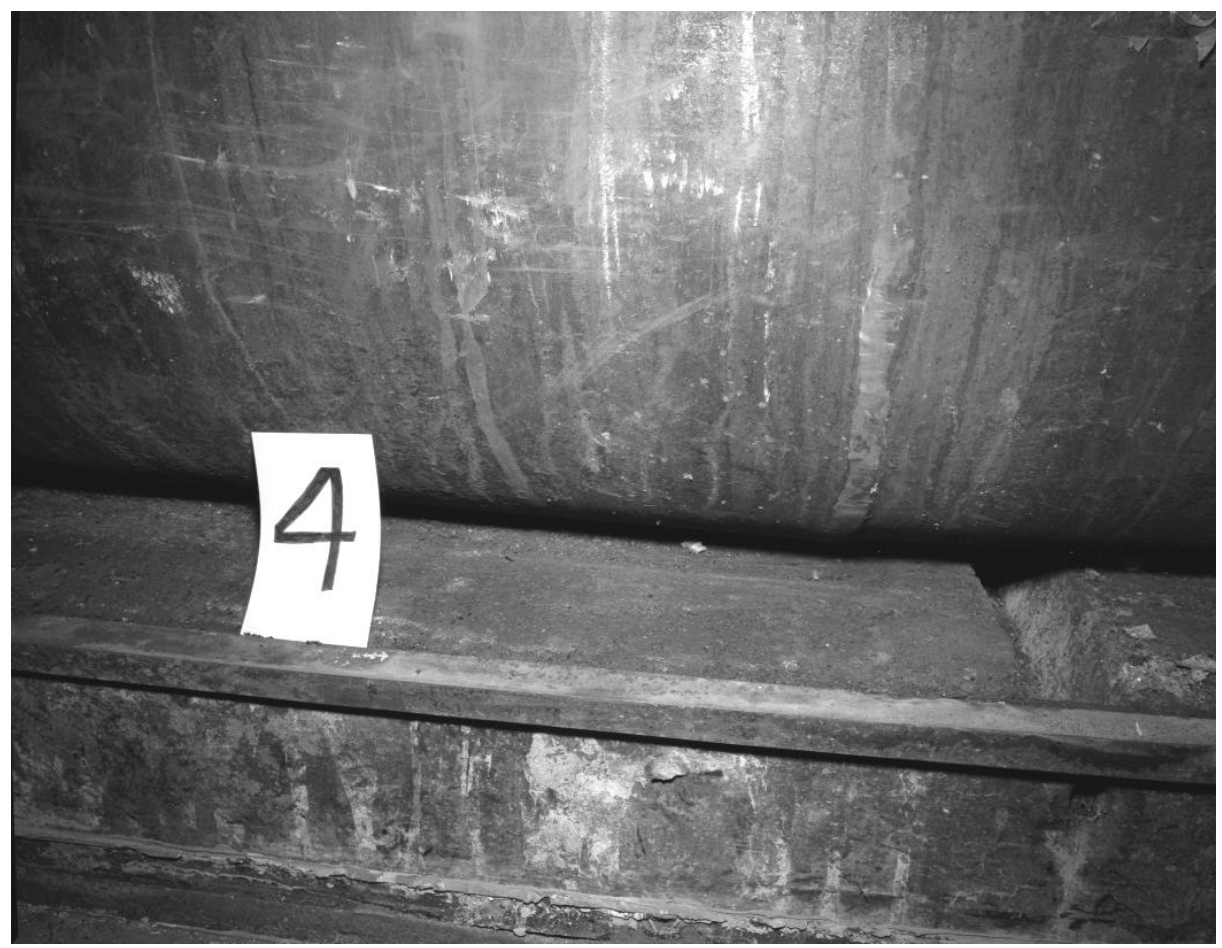

Figure 5-7. Kaolite Condition (Soggy and Mushy for 1/8 in. Depth) (57482-21 Photo) (Taken 3/24/72)

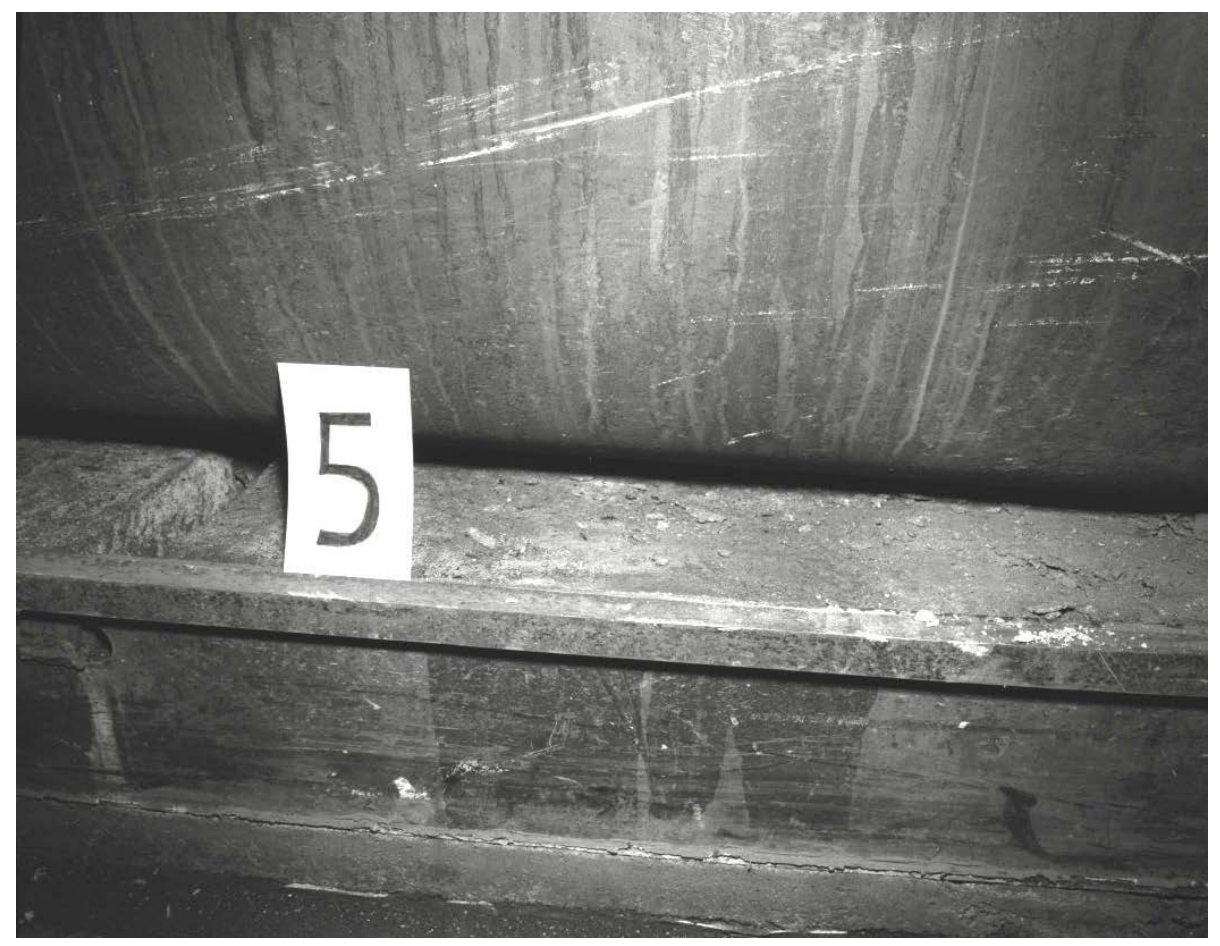

Figure 5-8. Kaolite Condition (1/8 in. Crust) (57482-19 Photo) (Taken 3/24/72) 
RPP-RPT-54818, Rev. 0

\subsection{TANK BOTTOM FLATNESS}

On August 9, 1971, it was noted in the log that a survey crew checked the tank AZ-101

secondary liner bottom to determine the amount of distortion and it was noted that the results "are on file." While, no specific survey report was located and no NCRs were found on out-offlatness relating to either tank bottom for either the primary tank or secondary liner, it was later noted in a deficiency report for tank AZ-101, regarding the increased kaolite thickness from 8 in. to 10 in., that the cause was "the irregular surface of the secondary bottom." A logbook entry on September 17, 1971 notes "some cracks 1 " deep being repaired," which could have been the result of secondary liner bulging. Based on the lack of documented deficiencies, it is assumed that all measurements of bottom flatness met specification.

Some minor rippling was noted in the logbook for tank AZ-102 during pouring of the kaolite. It was stated on September 24, 1971 that "the floor plate has dropped down under the weight of the kaolite in section 3 in TK 102. Their seams (sic) to be a blister in the tank floor plate sections 1 and 2 also." Later on the same day, it is noted that the "steel plate buckled down on section 2 about 3/8 inch, but occurred near center. No visible change from 15 feet toward outer ring." On October 5, 1971, chipping and repair of badly cracked Kaolite in section 28 is noted. These resulting cracks are seemingly similar to those discovered after the refractory pour in tank AY102, possibly caused by secondary liner bulging.

On November 22, 1971, it was noted that "the AZ-101 primary bottom was checked for deformation and found to be acceptable without flattening." No specific notation was found in the logs for a tank AZ-102 primary tank bottom survey and, as mentioned above, no deficiency reports on the subject were found for either tank. Based on the lack of specific negative reports, it is assumed both primary tank bottoms met specification.

\subsection{ISSUES UNIQUE TO 241-AZ TANK FARM}

\subsubsection{Radiograph Misrepresentation Discovery}

On August 6, 1971, a memorandum, located in Appendix C as App Figure C-17, was sent from D.S. Mager to A. Short regarding 241-AZ tank farm radiography. In this document, Mr. Mager discusses his review of available radiographs to update the status of weld acceptability and prevent possible delay of lowering the tank bottom as scheduled on 8/4/1971. Through review of several radiographs, it was apparent that four of the radiographs were not a match to the actual area they were referenced to, but were simply copies of radiographs from more easily accessible areas of the tank. The following comment was made within the document:

"It is significant to note that all four areas not radiographed correctly are under the temporary truss supports. This makes it necessary for the radiographer to move the equipment from the top side of the tank bottom to the underside of the tank bottom.

It is my conclusion, based on the evidence available, that the misrepresentation of weld areas was intentional, solely on the part of the radiographer and/or his assistant, and that his purpose for doing so was to save time and physical labor." 
Following this discovery, a letter written by J.H. Slaughter on July 13, 1972 discussed an audit finding related to this issue. See Appendix C, App Figure C-5, for the full document. The finding related to the misrepresented radiographs was as follows:

“The substitute radiographs from the radiographer's misrepresentation were not filed along with those accepted."

A response to the audit finding was produced by Edgar F. Smith on July $28^{\text {th }}$ in a letter, included as App Figure C-6 in Appendix C. His response was the following:

"Regarding falsified radiographs that were detected by our inspection personnel, we do not believe such radiographs should be inserted in the same filing system used for official project radiographs. However, they will be suitably identified so that they will not be misconstrued and filed so they are readily available."

It is important to note that the welds were properly radiographed and official accepted records were obtained to replace those that were misrepresented.

\subsubsection{Fires During Construction}

Two fires occurred in tank AZ-102 during construction. The first occurred on 2/10/1972 in the primary tank. The fire was discovered at noon and extinguished by the fire department after their arrival. The log states "damage was limited to the canvas material used for heating the kaolite and some of the wood used for scaffolding." Welding of the second course of shell ring plates was occurring on the primary tanks at that time.

The second fire occurred on 2/19/1972 in the tank AZ-102 annulus. The fire was extinguished before the fire department could arrive. It was reported to have been started by welding sparks igniting gas under the plywood scaffolding in the annulus. The job log did not describe the extent of the damage, which is assumed to be minimal given the short duration of the fire.

No similar fires were noted for tank AZ-101.

\subsubsection{Knuckles Swapped Between Tanks AZ-101 and AZ-102}

When installing the bottom knuckles on tanks AZ-101 and AZ-102, the plates used were reversed. The plates intended for tank AZ-102 were installed on tank AZ-101 and vice versa. Two reports were written to make note of this and they are included within Appendix C as App Figure C-18 and App Figure C-19 .

For the tank AZ-102 plates used on tank AZ-101 the following detail is provided:

“The primary knuckles, Piece Marks BKP-A, BKP-B, BKP-C, BKP-D, BKP-E, BKP-F, $B K P-G, B K P-H$, plus the corresponding $X$-rays made in Provo reflect Tank Number 102 on both the knuckles and the X-rays. These knuckles were used on Tank Number 101.” 
The recommended disposition for this reversal was the following:

"The knuckles will be documented on the as-built drawings with the piece mark number and orientation as shown on the attached drawing. The X-rays will be filed in the Tank Number 101 X-ray Report File.”

For the tank AZ-101 plates used on tank AZ-102 the following detail is provided:

“The primary knuckles, Piece Marks BKP-1A, BKP-1B, BKP-1C, BKP-1D, BKP-1E, $B K P-1 F, B K P-1 G, B K P-1 H$, plus the corresponding $X$-rays made in Provo reflect Tank Number 101 on both the knuckles and the X-rays. These knuckles were used on Tank Number 102."

The recommended disposition for this reversal was the following:

"The knuckles will be documented on the as-built drawings with the piece mark number and orientation as shown on the attached drawing. The X-rays will be filed in the Tank Number 102 X-ray Report File.” 


\subsection{CONCLUSIONS}

The leak assessment report for AY-102, RPP-ASMT-53793, identified first-of-a-kind construction difficulties and trial-and-error repairs as major contributing factors in the failure of that tank. To determine if improvements in DST construction continued, a review and evaluation of the construction records for the 241-AZ tank farm was completed to determine if similar or other difficulties were present.

After a review of the construction history of the 241-AZ tank farm, it is concluded that, during construction of the 241-AZ tank farm, there were fewer construction difficulties. Table 6-1 includes a summary of the issues seen in tank AY-102 and the 241-AZ tank farm, focusing on the critical difficulties that were identified in RPP-ASMT-53793.

There were fewer problems noted with welding of the secondary liner bottom and primary tank bottom than were seen in 241-AY tank farm. The thickness of the secondary liner bottom in 241AZ tank farm was increased to 3/8 in. (from 1/4 in 241-AY tank farm) and only a minor mention of bulges in the secondary liner was noted. The thickness of the primary bottom was increased to $1 / 2$ inch (from 3/8 in. in 241-AY tank farm). The primary liner weld rejection rate for tank AZ101 (14.5 percent) and tank AZ-102 (6.3 percent) was much less than that for tank AY-102 (33.8 percent).

Refractory installation for the project used a different pour pattern, but similar techniques to those used for the 241-AY tank farm. Greater effort was placed on preventing exposure of the unfired refractory to freezing weather and water saturation. Although some issues with this protection were noted, no significant refractory repairs were required after post-weld stress relieving. Refractory thickness in this farm remained difficult to control, with sections noted up to 10 in. This was primarily attributed to an irregular surface of the secondary liner bottom. The refractory selected for 241-AZ tank farm, Kaolite 2000, was tested and stated to meet specifications, although testing of unfired materials showed poor resistance to simulated caustic waste. The original specification for the refractory compressive strength of 200 psi was relaxed to 130 psi and remained at the lower value for future tank farms.

Initial attempts at stress relieving were unsuccessful because of large temperature differentials, inability to control heat spreading, and large overshoot of desired temperatures. Physical modifications to the stress relieving were made and the process was restarted. These changes allowed for more efficient and effective stress relief in tanks AZ-101 and AZ-102 than was seen in tank AY-102 due to protection of refractory from freezing and water saturation.

The most significant deficiency found was the presence of plate laminations and near-surface defects. Extensive magnetic particle testing was performed. Grinding of the primary tank bottom plate up to 1/16 in. was allowed to remove near-surface laminations. In tank AZ-102, six plates in the upper shell ring were found to have laminations, with four of them severe enough to require replacement prior to heat treatment and 2 additional ones accepted as-is. 
Other issues, unique to 241-AZ tank farm were noted. Both primary tanks had leaks found during the hydrostatic test, but these leaks were in the dome sections above the normal waste level. All leaks were repaired, with this re-weld occurring after stress relieving.

A square groove was discovered ground into one weld in the lower knuckle of primary wall plates in the tank AZ-101 primary sidewall after stress relief. This condition was evaluated and accepted as-is. Fires occurred during construction in the annulus of tank AZ-102 and in the bottom of the primary tank in AZ-102, but the daily logbooks did not indicate any significant damage was caused by these two fires.

Minor pitting, up to 0.010 in., was noted in tank AZ-101 as a result of extended storage of five ft. of untreated water from the hydrostatic test. There were repairs and modification made to the refractory retaining band as a result of installation errors. These minor issues are not expected to significantly affect the tank integrity.

In conclusion, in the 241-AZ tank farm, the second DST farm constructed, the prior contractor was used (PDM) and fewer construction issues were noted than with tank AY-102 construction. Secondary liner thickness was increased and, while fewer issues were noted with bulging, the thickness of the refractory was increased due to bottom irregularities. No evidence that these irregularities did not meet specification was found. Refractory weather protection was more evident and no major refractory repairs were required. The primary liner weld rework rate was low and the effectiveness of the post-weld stress relieving was judged to be greater.

Table 6-1. Summary Comparison 241-AZ Tank Farm Construction to Tank AY-102

\begin{tabular}{|c|c|c|c|}
\hline Tank & AY-102 & AZ-101 & AZ-102 \\
\hline $\begin{array}{l}\text { Evaluation } \\
\text { Document }\end{array}$ & $\begin{array}{l}\text { RPP-ASMT-53793, Tank } \\
\text { 241-AY-102 Leak } \\
\text { Assessment Report }\end{array}$ & \multicolumn{2}{|c|}{$\begin{array}{l}\text { RPP-RPT-54818, 241-AZ Tank Farm Construction } \\
\text { Extent of Condition Review for Tank Integrity }\end{array}$} \\
\hline $\begin{array}{l}\text { Construction } \\
\text { Order }\end{array}$ & $1^{\text {st }}$ DST constructed & $1^{\text {st }}$ DST in $2^{\text {nd }}$ Farm & $2^{\text {nd }}$ DST in $2^{\text {nd }}$ Farm \\
\hline $\begin{array}{l}\text { Construction } \\
\text { Contractor }\end{array}$ & \multicolumn{3}{|c|}{ Pittsburgh-Des Moines (PDM) Steel Company } \\
\hline $\begin{array}{l}\text { Secondary } \\
\text { Liner Bottom } \\
\text { Material }\end{array}$ & $\begin{array}{l}\text { 0.25-in. plate, ASTM A515, } \\
\text { Gr } 60\end{array}$ & \multicolumn{2}{|c|}{ 0.375-in. plate, ASTM A515, Gr 60} \\
\hline $\begin{array}{l}\text { Secondary } \\
\text { Liner Bottom } \\
\text { Bulges }\end{array}$ & $\begin{array}{l}\text { Excessive distortion and } \\
\text { bulges noted throughout. } \\
\text { Maximum slope noted as } \\
\text { much as } 1 \text { inch per foot. } 22 \\
\text { places exceed } 2 \text { inch peak- } \\
\text { to-valley tolerance. }\end{array}$ & $\begin{array}{l}\text { Only minor notation, no } \\
\text { deficiencies or NCRs } \\
\text { found. Noted that } \\
\text { Kaolite thickness was } \\
\text { increased due to } \\
\text { irregular bottom. }\end{array}$ & $\begin{array}{l}\text { Only minor notation, no } \\
\text { deficiencies or NCRs } \\
\text { found, Log noted that plate } \\
\text { dropped 0.375-in. when } \\
\text { Kaolite poured. }\end{array}$ \\
\hline $\begin{array}{l}\text { Primary Tank } \\
\text { Bottom } \\
\text { Material }\end{array}$ & $\begin{array}{l}0.375 \text {-in. plate, ASTM 515, } \\
\text { Gr } 60\end{array}$ & \multicolumn{2}{|c|}{ 0.5-in. plate, ASTM 515, Gr 60} \\
\hline
\end{tabular}


Table 6-1. Summary Comparison 241-AZ Tank Farm Construction to Tank AY-102

\begin{tabular}{|c|c|c|c|}
\hline Tank & AY-102 & AZ-101 & AZ-102 \\
\hline \multirow[b]{2}{*}{$\begin{array}{l}\text { Primary Tank } \\
\text { Bottom Weld } \\
\text { Rework }\end{array}$} & $33.8 \%$ & $14.5 \%$ & $6.3 \%$ \\
\hline & $\begin{array}{l}\text { Ultimately all welds were } \\
\text { accepted and stress relieved, } \\
\text { although problems with that } \\
\text { process were noted. }\end{array}$ & $\begin{array}{l}\text { Ultimately all welds } \\
\text { were accepted and stress } \\
\text { relieved. }\end{array}$ & $\begin{array}{l}\text { Ultimately all welds were } \\
\text { accepted and stress } \\
\text { relieved. }\end{array}$ \\
\hline $\begin{array}{l}\text { Primary Tank } \\
\text { Bottom Bulges }\end{array}$ & $\begin{array}{l}\text { Primary bottom flatness } \\
\text { described as “generally } \\
\text { good.” However, during } \\
\text { refractory repair, much of } \\
\text { the primary tank bottom } \\
\text { wasn't in contact with the } \\
\text { refractory. Voids were } \\
\text { filled with Styrofoam. }\end{array}$ & $\begin{array}{l}\text { Noted as “acceptable } \\
\text { without flattening” }\end{array}$ & $\begin{array}{l}\text { No specific notation } \\
\text { found. }\end{array}$ \\
\hline $\begin{array}{l}\text { Stress Relieving } \\
\text { Process }\end{array}$ & $\begin{array}{l}\text { Required } 2 \text { days to remove } \\
\text { all the water in the } \\
\text { refractory. Lowest } \\
\text { temperature recorder just } \\
\text { prior to initiating } 3 \text { hold } \\
\text { time was } 915^{\circ} \mathrm{F} \text { (accepted as } \\
\text { being } 1000^{\circ} \mathrm{F} \text { ). }\end{array}$ & $\begin{array}{l}\text { Initial attempt aborted, } \\
\text { modification made and } \\
2^{\text {nd }} \text { attempt successful } \\
\text { reached } 1050^{\circ} \mathrm{F} \text { for } 2 \\
\text { hour hold. No refractory } \\
\text { steaming noted. }\end{array}$ & $\begin{array}{l}\text { Modified procedure used, } \\
\text { minimum temperature was } \\
1000^{\circ} \mathrm{F} \text { for } 3 \text { hour hold. }\end{array}$ \\
\hline Refractory & Kaolite 2200LI & \multicolumn{2}{|c|}{ Kaolite 2000} \\
\hline $\begin{array}{l}\text { Refractory } \\
\text { Protection }\end{array}$ & $\begin{array}{l}\text { Allowed to saturate with } \\
\text { rain water, not protected } \\
\text { from freezing. }\end{array}$ & \multicolumn{2}{|c|}{$\begin{array}{l}\text { Measures taken to heat refractory and keep water out } \\
\text { (heaters, tarping). Some failures noted but generally } \\
\text { good. }\end{array}$} \\
\hline $\begin{array}{l}\text { Refractory } \\
\text { Condition }\end{array}$ & $\begin{array}{l}\text { After hydrostatic test, } \\
\text { refractory found to be very } \\
\text { degraded, extensively } \\
\text { cracked, and spalled. } \\
\text { Samples showed excessive } \\
\text { carbonation. }\end{array}$ & \multicolumn{2}{|c|}{$\begin{array}{l}\text { Logs indicate post-hydrostatic test inspection } \\
\text { performed, no reports on deficiencies could be found. }\end{array}$} \\
\hline $\begin{array}{l}\text { Refractory } \\
\text { Repair }\end{array}$ & $\begin{array}{l}\text { Major- } 21 \text { inches of } \\
\text { perimeter removed and } \\
\text { replaced with structural } \\
\text { concrete. }\end{array}$ & \multicolumn{2}{|c|}{$\begin{array}{l}\text { Minor repairs made during initial pour, none after } \\
\text { post-weld stress relieving. }\end{array}$} \\
\hline
\end{tabular}


Table 6-1. Summary Comparison 241-AZ Tank Farm Construction to Tank AY-102

\begin{tabular}{|c|c|c|c|}
\hline Tank & AY-102 & AZ-101 & AZ-102 \\
\hline Other Issues & $\begin{array}{l}\text { Unsupported areas of } \\
\text { primary bottom filled with } \\
\text { Styrofoam as backing for } \\
\text { perimeter refractory } \\
\text { replacement concrete pours. }\end{array}$ & $\begin{array}{l}\text { Plate laminations in } \\
\text { primary tank bottom } \\
\text { ground out as much as } \\
\text { 0.0625-in. depth. } \\
\text { Weld grind out in lower } \\
\text { knuckle weld seam } \\
\text { found after stress relief } \\
\text { and accepted based on } \\
\text { expert opinion. } \\
\text { Minor leaks above } \\
\text { normal waste level } \\
\text { found during hydrostatic } \\
\text { test, (and after stress } \\
\text { relief). Water level } \\
\text { lowered, welds repaired. }\end{array}$ & $\begin{array}{l}\text { Plate laminations, within } \\
\text { ASME Boiler and Pressure } \\
\text { Vessel Code allowance } \\
\text { found in two plates in } \\
\text { upper shell ring and } \\
\text { accepted. Four other } \\
\text { plates replaced. } \\
\text { Minor leaks above normal } \\
\text { waste level found during } \\
\text { hydro test, (and after stress } \\
\text { relief). Water level } \\
\text { lowered, welds repaired. }\end{array}$ \\
\hline $\begin{array}{l}\text { Overall } \\
\text { Conclusion on } \\
\text { Construction } \\
\text { Difficulties }\end{array}$ & $\begin{array}{l}\text { Difficultly with liner } \\
\text { fabrication and the castable } \\
\text { refractory left the tank with } \\
\text { unsupported areas in the } \\
\text { tank bottom and unexpected } \\
\text { residual stresses in the tank } \\
\text { bottom that probably } \\
\text { contributed to failure. }\end{array}$ & \multicolumn{2}{|c|}{$\begin{array}{l}\text { 241-AZ tank farm, the second DST farm constructed, } \\
\text { used the same contractor as in 241-AY tank farm } \\
\text { (PDM) and far fewer issues were noted. Secondary } \\
\text { liner bottom thickness was increased and fewer bulges } \\
\text { were seen. Refractory weather protection was } \\
\text { improved and no major refractory repairs were } \\
\text { required. The thickness of the primary tank bottom } \\
\text { was increased and the overall primary tank weld } \\
\text { rework rate was low. Post-weld stress relief process } \\
\text { was improved. Records of unsupported primary } \\
\text { bottom sections and other areas of high residual stress } \\
\text { were not found. Plate laminations were present in } \\
\text { both primary liners, minor areas were ground out, and } \\
\text { plates with major areas were replaced. Leaks found } \\
\text { after hydrostatic test were above the normal waste } \\
\text { level, repaired, and are not expected to negatively } \\
\text { impact tank integrity. }\end{array}$} \\
\hline
\end{tabular}


RPP-RPT-54818, Rev. 0

\subsection{REFERENCES}

ARH-1437, 1970, Design Criteria Purex AZ Tank Farm, Atlantic Richfield Hanford Company, Richland, Washington.

BNWL-B-56, 1971, Evaluation of Kaolite-2000 Insulating Castable, Battelle Pacific Northwest Laboratory, Richland Washington.

RPP-19097, 2003, Evaluation of Insulating Concrete in Hanford Double-Shell Tanks, CH2M Hill Hanford Group, Inc., Richland, Washington.

RPP-ASMT-53793, 2012, Tank 241-AY-102 Leak Assessment Report, Washington River Protection Solutions, Richland, Washington.

H-2-63796, 1970, 241-AY Tank Farm Annulus Pump Pit Arrangement, Vitro Hanford Engineering Services, Richland, Washington.

H-2-67243, 1973, Structural Concrete Tank Foundation Plan \& Details Tank 241-AZ-101 \&102, Vitro Hanford Engineering Services, Richland, Washington.

H-2-67245, 1973, Concrete Tank Section \& Hanch Reinforcement, Rev. 1, Vitro Hanford Engineering Services, Richland, Washington.

H-2-67295, 1974, Instrumentation Insulating Concrete Plan \& Details, Vitro Hanford Engineering Services, Richland, Washington.

H-2-67317, 1973, Tanks 101 \& 102 Sections and Details 241-AZ Tank Farm, Sheet 1, Rev. 1, Vitro Hanford Engineering Services, Richland, Washington.

H-14-010507, 2010, Dome Penetration Schedules (WST/WSTA) Tank 241-AZ-101, Sheet 1, Rev. 15, Washington River Protection Solutions LLC, Richland, Washington.

H-14-010507, 2012, Dome Penetration Schedules (WST/WSTA) Tank 241-AZ-102, Sheet 2, Rev. 12, Washington River Protection Solutions LLC, Richland, Washington.

HWS-8981, 1970, Specifications for Excavation and Tank Foundations Project HAP-647 Tank Farm Expansion 241-AZ Tank Farm, Vitro Hanford Engineering Services, Richland, Washington.

HWS-8982, 1970, Specifications for Primary and Secondary Steel Tanks Project HAP-647 Tank Farm Expansion 241-AZ Tank Farm, Vitro Hanford Engineering Services, Richland, Washington.

HWS-8867, 1972, Specifications for Completion of Tank 102 Project HAP-647 Tank Farm Expansion, 241-AZ Tank Farm, Automation Industries, Inc. Vitro Engineering Division, Richland, Washington. 
HNF-4957, 1999, 241-AZ Double-Shell Tanks Integrity Assessment, Rev. 0, Lockheed Martin Hanford Corporation, Richland, Washington.

WRPS-1204931, 2012, Double-Shell Tank 241-AY-102 Primary Tank Leak Extent of Condition Evaluation and Recommended Annulus Visual Inspection Intervals, Washington River Protection Solutions LLC, Richland, Washington. 
RPP-RPT-54818, Rev. 0

APPENDIX A 241-AZ Tank Farm Key Event Table 
RPP-RPT-54818, Rev. 0

\begin{tabular}{|c|c|c|c|c|c|}
\hline Reference & Date & Log & Tank & Comments & Event \\
\hline 1 & 10/9/1970 & Construction & & $\begin{array}{l}\text { Survey crew lays out tank } \\
\text { centerlines. }\end{array}$ & Construction \\
\hline 2 & $10 / 16 / 1970$ & Construction & & $\begin{array}{l}\text { JAJ moving existing cathodic } \\
\text { anode per H-2-67242. }\end{array}$ & \\
\hline 3 & $11 / 16 / 1970$ & Construction & & Excavation started & Construction \\
\hline 4 & $12 / 3 / 1970$ & Construction & & $\begin{array}{l}\text { Survey crew checking } \\
\text { elevation of excavation } \\
615.25 @ 10 \text { am. }\end{array}$ & \\
\hline 5 & $12 / 4 / 1970$ & Construction & & $\begin{array}{l}\text { Stabilizing material placed } \\
\text { and level per spec. Some } \\
\text { material larger than spec call } \\
\text { for. }\end{array}$ & \\
\hline 6 & $12 / 11 / 1970$ & Construction & & $\begin{array}{l}\text { Forms in place for leak } \\
\text { detection system. }\end{array}$ & \\
\hline 7 & $12 / 11 / 1970$ & Construction & & $\begin{array}{l}\text { Concrete placed on leak } \\
\text { detection well footings, Well } \\
\text { footings are } 5 / 8 \text { inch low, } \\
\text { will be corrected by having } 1 \\
\text { and } 5 / 8 \text { inch of grout rather } \\
\text { than } 1 \text { inch as shown on } \\
\text { drawing. }\end{array}$ & Construction \\
\hline 8 & $12 / 15 / 1970$ & Construction & & $\begin{array}{l}\text { Setting perimeter from for } \\
\text { tank foundation. }\end{array}$ & \\
\hline 9 & $12 / 22 / 1970$ & Construction & & $\begin{array}{l}\text { Mr. Pegram said to have } \\
\text { error in plates corrected } \\
\text { would require sending them } \\
\text { to Portland. Wants to install } \\
\text { as is. Slaughter is looking } \\
\text { into it. }\end{array}$ & \\
\hline 10 & $12 / 23 / 1970$ & Construction & & $\begin{array}{l}\text { Slaughter said to use plates as } \\
\text { is. Fitters welding drain pipe. }\end{array}$ & \\
\hline 11 & $12 / 31 / 1970$ & Construction & & $\begin{array}{l}\text { Soil compaction results, } \\
\text { density } 94 \% \text { with } 5.5 \% \\
\text { water at } 4 \text { vibrator passes, } \\
97 \% \text { with } 5.5 \% \text { water with } 6 \\
\text { vibrator passes. }\end{array}$ & \\
\hline 12 & $1 / 4 / 1971$ & Construction & & $\begin{array}{l}\text { More compaction tests, } 97 \% \\
\text { with } 9.5 \% \text { water, } 100 \% \\
\text { compaction with } 11.5 \% \\
\text { water. }\end{array}$ & \\
\hline
\end{tabular}


RPP-RPT-54818, Rev. 0

\begin{tabular}{|c|c|c|c|c|c|}
\hline Reference & Date & Log & Tank & Comments & Event \\
\hline 13 & 1/5/1971 & Construction & 101 & $\begin{array}{l}\text { Drain line tied into LDP } \\
\text { riser. }\end{array}$ & \\
\hline 14 & 1/6/1971 & Construction & 101 & $\begin{array}{l}\text { LDP riser and drain line leak } \\
\text { tested, } 12 \mathrm{ft} \text { of water for } 30 \\
\text { minutes, coating flaws found } \\
\text { and repaired. }\end{array}$ & Construction / Issue \\
\hline 15 & 1/8/1971 & Instrumentation & 101 & $\begin{array}{l}\text { Conduits for base TCs } \\
\text { installed. }\end{array}$ & \\
\hline 16 & $1 / 11 / 1971$ & Construction & & 1st rebar for base delivered. & \\
\hline 17 & $1 / 11 / 1971$ & Construction & 101 & $\begin{array}{l}\text { Re steel installation started } \\
\text { on TK 101, outside forming } \\
\text { completed. }\end{array}$ & Construction \\
\hline 18 & $1 / 27 / 1971$ & Construction & 102 & $\begin{array}{l}\text { LDP riser and drain line leak } \\
\text { tested, } 12 \mathrm{ft} \text { of water for } 30 \\
\text { minutes, coating flaws found } \\
\text { and repaired. }\end{array}$ & Construction / Issue \\
\hline 19 & $1 / 28 / 1971$ & Instrumentation & & $\begin{array}{l}\text { TC system for monitoring } \\
\text { pour temps installed. }\end{array}$ & \\
\hline 20 & 2/11/1971 & Construction & 101 & $\begin{array}{l}\text { Removal of drain slot } \\
\text { blockouts initiated. }\end{array}$ & \\
\hline 21 & 2/16/1971 & Construction & & $\begin{array}{l}\text { Cleanup on base on } 101 \text {, } \\
\text { drain line blockout installed } \\
\text { on } 102 \text { in prep for base pour. }\end{array}$ & \\
\hline 22 & 2/24/1971 & Construction & 101 & $\begin{array}{l}\text { 1/4 inch thick CS plate } \\
\text { installed on TK } 101 \text { and leak } \\
\text { detection risers backfilled. }\end{array}$ & \\
\hline 23 & 3/1/1971 & Construction & & $\begin{array}{l}\text { Cleanup work completed on } \\
\text { concrete bases, final } \\
\text { inspection bv F. Ardnt and A. } \\
\text { Short. }\end{array}$ & Construction \\
\hline 24 & $5 / 5 / 1971$ & Construction & & $\begin{array}{l}\text { Received Mill Certs of } \\
\text { material purchased for tank } \\
\text { fabrication. }\end{array}$ & \\
\hline 25 & $5 / 11 / 1971$ & Construction & & $\begin{array}{l}\text { Discussion on automatic } \\
\text { weld procedure and } \\
\text { undercutting. }\end{array}$ & \\
\hline 26 & $5 / 25 / 1971$ & Construction & & $\begin{array}{l}\text { Request to use Ir192 on } \\
\text { primary knuckles. }\end{array}$ & \\
\hline 27 & $6 / 14 / 1971$ & Construction & & $\begin{array}{l}\text { Weld test radiograph too dark } \\
\text { and to be repeated. }\end{array}$ & \\
\hline
\end{tabular}


RPP-RPT-54818, Rev. 0

\begin{tabular}{|c|c|c|c|c|c|}
\hline Reference & Date & Log & Tank & Comments & Event \\
\hline 28 & $6 / 18 / 1971$ & Construction & & $\begin{array}{l}\text { 1st steel for plates arrived, } \\
\text { appears satisfactory. }\end{array}$ & \\
\hline 29 & $6 / 22 / 1971$ & Construction & 101 & $\begin{array}{l}\text { Plywood placed on slab, } \\
\text { temporary supports erected, } \\
\text { 1st secondary plate placed. }\end{array}$ & Construction \\
\hline 30 & $6 / 23 / 1971$ & Construction & 101 & $\begin{array}{l}\text { Began tacking bottom sketch } \\
\text { plates - } 101 \text { secondary. }\end{array}$ & \\
\hline 31 & $6 / 25 / 1971$ & Construction & & $\begin{array}{l}\text { Test plate welded using } \\
\text { automatic welder. }\end{array}$ & \\
\hline 32 & 6/28/1971 & Construction & 101 & $\begin{array}{l}\text { Welding on bottom plates } \\
\text { initiated using automatic } \\
\text { welder. }\end{array}$ & Construction \\
\hline 33 & 6/29/1971 & Construction & 101 & $\begin{array}{l}\text { Welding on bottom plates } \\
\text { continues. }\end{array}$ & \\
\hline 34 & $7 / 2 / 1971$ & Construction & 101 & $\begin{array}{l}\text { Welding on bottom plates } \\
\text { continues. }\end{array}$ & \\
\hline 35 & 7/9/1971 & Construction & 101 & Knuckle sections placed. & Construction \\
\hline 36 & $7 / 12 / 1971$ & Construction & 101 & $\begin{array}{l}\text { New weld procedure (71-19) } \\
\text { implemented. }\end{array}$ & \\
\hline 37 & $7 / 14 / 1971$ & Construction & & $\begin{array}{l}\text { Welding knuckles on } 101 \text { and } \\
\text { tacking bottom plates for } \\
102 .\end{array}$ & \\
\hline 38 & 7/20/1971 & Construction & 101 & $\begin{array}{l}\text { Welding knuckles on } 101 \text { and } \\
\text { welding knuckles to bottom } \\
\text { plate. }\end{array}$ & \\
\hline 39 & $7 / 22 / 1971$ & Construction & 101 & $\begin{array}{l}\text { All bottom plate weld } \\
\text { radiographed once, } 3 \text { seams } \\
\text { accepted entire length, } \\
\text { identification on } 101 \\
\text { knuckles clarified. }\end{array}$ & \\
\hline 40 & 7/27/1971 & Construction & 101 & $\begin{array}{l}\text { Final closure seam on } \\
\text { secondary bottom completed. }\end{array}$ & Construction \\
\hline 41 & $7 / 28 / 1971$ & Construction & 101 & $\begin{array}{l}\text { Repair work on welds } \\
\text { continues, installing trusses } \\
\text { to allow lowering. }\end{array}$ & \\
\hline 42 & 8/4/1971 & Construction & 101 & $\begin{array}{l}\text { Water found filling drain line } \\
\text { and LDP riser, must be } \\
\text { removed prior to placing } \\
\text { sump insulation. }\end{array}$ & Issue \\
\hline
\end{tabular}




\begin{tabular}{|c|c|c|c|c|c|}
\hline Reference & Date & $\log$ & Tank & Comments & Event \\
\hline 43 & 8/5/1971 & Construction & 101 & $\begin{array}{l}\text { Final inspection and cleaning } \\
\text { of slab, secondary lowered, } \\
\text { minor problem noted with } \\
\text { center ring insertion into } \\
\text { sump, bottom shifted slightly. }\end{array}$ & Construction / Issue \\
\hline 44 & 8/5/1971 & Construction & 102 & $\begin{array}{l}\text { Bottom plate welding done } \\
\text { and fitting knuckle sections. }\end{array}$ & Construction \\
\hline 45 & 8/9/1971 & Construction & 101 & $\begin{array}{l}\text { Survey crew shot } 101 \\
\text { secondary tank bottom to } \\
\text { determine amount of } \\
\text { distortion, "results on file." }\end{array}$ & Issue \\
\hline 46 & 8/9/1971 & Construction & 102 & $\begin{array}{l}\text { WADCO contacted about } \\
\text { weld soundness issues on } 102 \\
\text { knuckle sections. }\end{array}$ & \\
\hline 47 & $8 / 10 / 1971$ & Construction & 102 & $\begin{array}{l}\text { Some radiographs are of sub- } \\
\text { standard quality. Long } \\
\text { discussion of weld undercut } \\
\text { on horizontal welds. }\end{array}$ & \\
\hline 48 & $8 / 10 / 1971$ & Construction & 102 & $\begin{array}{l}\text { Radiographs of two knuckle } \\
\text { sections on } 102 \text { have less } \\
\text { dense section, possible un- } \\
\text { fused weld layer. WADCO } \\
\text { did UT test and determined } \\
\text { weld is acceptable, no cause } \\
\text { found for bad indication. }\end{array}$ & Issue \\
\hline 49 & $8 / 11 / 1971$ & Construction & 101 & $\begin{array}{l}101 \text { secondary bottom } \\
\text { vacuum box tested and no } \\
\text { defects found. Welding of } \\
\text { first shell ring begins. }\end{array}$ & \\
\hline 50 & $8 / 11 / 1971$ & Construction & 102 & $\begin{array}{l}\text { Welding of knuckle } \\
\text { continues noting the weld } \\
\text { reject rate has decreased from } \\
\text { TK } 101 \text {. Reject rate on TK } \\
101 \text { secondary bottom given } \\
\text { as } 3.5 \% \text {, based on an average } \\
\text { of } 3 \text { inches per rejected } \\
\text { radiograph. }\end{array}$ & \\
\hline 51 & $8 / 12 / 1971$ & Construction & 101 & $\begin{array}{l}\text { Installation of kaolite retainer } \\
\text { ring. }\end{array}$ & Construction \\
\hline 52 & $8 / 16 / 1971$ & Construction & 102 & $\begin{array}{l}\text { Noted significant } \\
\text { improvement on welds on Tk } \\
102 .\end{array}$ & \\
\hline
\end{tabular}




\begin{tabular}{|c|c|c|c|c|c|}
\hline Reference & Date & Log & Tank & Comments & Event \\
\hline 53 & 8/16/1971 & Construction & 101 & $\begin{array}{l}\text { Kaolite retainer ring installed } \\
\text { upside down and in wrong } \\
\text { position. Will be lifted and } \\
\text { air supply pipe penetrations } \\
\text { modified. }\end{array}$ & Issue \\
\hline 54 & 8/17/1971 & Construction & 101 & $\begin{array}{l}\text { New weld procedure, } 45-3 \\
\text { approved for use. }\end{array}$ & \\
\hline 55 & 8/18/1971 & Construction & 101 & $\begin{array}{l}\text { Kaolite retainer ring will be } \\
\text { raised one inch above highest } \\
\text { point, requiring more kaolite } \\
\text { to fill lower areas, estimated } \\
\text { to be equal to } 1 \text { and } 5 / 8 \text { inch } \\
\text { for entire surface. }\end{array}$ & Issue \\
\hline 56 & 8/18/1971 & Construction & 101 & $\begin{array}{l}\text { Welder not using } 45-3 \\
\text { procedure as instructed. }\end{array}$ & \\
\hline 57 & 8/20/1971 & Construction & 102 & $\begin{array}{l}\text { Center air chamber ring will } \\
\text { be welded to secondary } \\
\text { bottom without raising it. Air } \\
\text { supply pipes will slope to } \\
\text { center. }\end{array}$ & Issue \\
\hline 58 & 8/23/1971 & Construction & 102 & $\begin{array}{l}\text { Began installing trusses on } \\
102 \text { bottom. }\end{array}$ & \\
\hline 59 & 8/25/1971 & Construction & & $\begin{array}{l}\text { Both LDP risers pumped out } \\
\text { by JAJ. } 4 \text { inch air supply } \\
\text { pipe identified as API } 25 \text { not } \\
\text { A53 as per spec. }\end{array}$ & \\
\hline 60 & 8/27/1971 & Construction & 101 & $\begin{array}{l}\text { Began tacking second shell } \\
\text { ring. }\end{array}$ & Construction \\
\hline 61 & 8/30/1971 & Construction & 102 & $\begin{array}{l}\text { Weld repair is ongoing on } 6 \\
\text { areas on } 102 \text { secondary } \\
\text { bottom. }\end{array}$ & \\
\hline 62 & 8/30/1971 & Construction & 101 & $\begin{array}{l}\text { Unqualified welder attached } \\
\text { unistrut to liner and shows } \\
\text { areas of undercut. }\end{array}$ & Issue \\
\hline 63 & 8/31/1971 & Construction & 102 & $\begin{array}{l}\text { Final radiographs on } 102 \\
\text { secondary bottom and bottom } \\
\text { lowered to slab. Center ring } \\
\text { misaligned with sump - fit up } \\
\text { of horizontal seams not per } \\
\text { procedure. }\end{array}$ & Construction / Issue \\
\hline
\end{tabular}




\begin{tabular}{|c|c|c|c|c|c|}
\hline Reference & Date & Log & Tank & Comments & Event \\
\hline 64 & 9/1/1971 & Kaolite & 101 & $\begin{array}{l}0.54 \text { inches of rain, a number } \\
\text { of kaolite bags not protected } \\
\text { and were wet. }\end{array}$ & \\
\hline 65 & 9/7/1971 & Kaolite & 101 & $\begin{array}{l}\text { Trial batches mixed, } 3 \text { bags } \\
\text { with } 8.5 \text { gal water, wet } \\
\text { density of } 16.5 \text { and } 16.7 \text { lbs } \\
\text { for } 1 / 5 \mathrm{cu} \mathrm{ft} \text {, coated with horn } \\
\text { cure } 30 \mathrm{D} \text {. }\end{array}$ & \\
\hline 66 & 9/8/1971 & Kaolite & 101 & Water meters calibrated. & \\
\hline 67 & 9/9/1971 & Kaolite & 101 & $\begin{array}{l}\text { Pour for section } 13 \text { initiated } \\
\text { at } 1: 25 \text { pm completed at } 4: 10 \\
\text { pm, temp measured and one } \\
\text { batch rejected. }\end{array}$ & Construction \\
\hline 68 & 9/9/1971 & Kaolite & 101 & $\begin{array}{l}\text { Pour for section } 11 \text { at } 8: 50 \\
\text { pm, completed at } 12: 45 \text {. }\end{array}$ & \\
\hline 69 & 9/10/1971 & Kaolite & 101 & $\begin{array}{l}\text { Air temp high } 102 \mathrm{~F} \text {, section } \\
15 \text { poured. }\end{array}$ & \\
\hline 70 & 9/10/1971 & Kaolite & 101 & Section 7 poured. & \\
\hline 71 & 9/11/1971 & Kaolite & 101 & Section 16 and 3 poured. & \\
\hline 72 & 9/12/1971 & Kaolite & 101 & Section 5 and 6 completed. & \\
\hline 73 & 9/12/1971 & Kaolite & 101 & $\begin{array}{l}\text { Section } 1 \text { completed, } \\
\text { occasional issues with } \\
\text { mixers, water meters, extra } \\
\text { bags noted throughout. }\end{array}$ & \\
\hline 74 & 9/13/1971 & Kaolite & 101 & $\begin{array}{l}\text { Completed section } 12 \text { and } \\
\text { section } 8 \text {. Will change to } 12 \\
\text { degree } 30 \mathrm{ft} \text { sections. }\end{array}$ & \\
\hline 75 & 9/14/1971 & Kaolite & 101 & $\begin{array}{l}\text { Pouring } 12^{\circ} 30 \mathrm{ft} \text { sections, } \\
\text { minimum cutout section to be } \\
3 \text { inches, section edges to be } \\
\text { prepared by spudding or } \\
\text { power wire brushing. } \\
\text { Method of vibration } \\
\text { questioned and changed. }\end{array}$ & Issue \\
\hline 76 & 9/14/1971 & Kaolite & 101 & $\begin{array}{l}\text { Mixer power broke and pour } \\
\text { blocked and suspended pour } \\
\text { in section } 23 \text {. }\end{array}$ & \\
\hline
\end{tabular}




\begin{tabular}{|c|c|c|c|c|c|}
\hline Reference & Date & Log & Tank & Comments & Event \\
\hline 77 & 9/15/1971 & Kaolite & 101 & $\begin{array}{l}\text { Temperature last night in tent } \\
\text { was } 50 \mathrm{~F} \text {, discussion of using } \\
\text { heaters. Air pipe being } \\
\text { placed. }\end{array}$ & Issue \\
\hline 78 & 9/15/1971 & Kaolite & 101 & $\begin{array}{l}\text { Poured three sections, test } \\
\text { cubes noted as fragile. }\end{array}$ & Issue \\
\hline 79 & 9/16/1971 & Kaolite & 101 & 4 batches rejected, bad mixer. & \\
\hline 80 & $9 / 16 / 1971$ & Kaolite & 101 & $\begin{array}{l}\text { Wind gust tore canvas tent, } \\
\text { pouring section } 14 \text {, chipping } \\
\text { kaolite from center pan. }\end{array}$ & \\
\hline 81 & 9/17/1971 & Kaolite & 101 & $\begin{array}{l}\text { TK } 101 \text { kaolite completed. } \\
\text { Battelle photographer onsite. } \\
\text { Some cracks 1" deep being } \\
\text { repaired. Heaters and temp } \\
\text { recorder being setup. }\end{array}$ & Construction / Issue \\
\hline 82 & 9/17/1971 & Instrumentation & 101 & $\begin{array}{l}\text { All TC conduit in kaolite in } \\
\text { correct position. }\end{array}$ & \\
\hline 83 & 9/18/1971 & Instrumentation & & $\begin{array}{l}\text { Instrument logs not reviewed } \\
\text { in details, problems noted } \\
\text { with TCs and strain gages for } \\
\text { several months. }\end{array}$ & \\
\hline 84 & 9/20/1971 & Kaolite & 101 & $\begin{array}{l}\text { Recorded low Temp was } \\
62 \mathrm{~F} \text {, curing to be complete at } \\
4 \mathrm{pm} \text {. Core drilling of kaolite } \\
\text { on TK } 101 \text { completed. }\end{array}$ & \\
\hline 85 & 9/21/1971 & Kaolite & 101 & $\begin{array}{l}\text { Took F\&G cores and filled } \\
\text { core holes. }\end{array}$ & \\
\hline 86 & 9/21/1971 & Kaolite & 101 & $\begin{array}{l}\text { Test on cores, low } 74 \text { psi, } \\
\text { high } 205,17 \text { below } 130 \text { psi } \\
\text { and } 148 \text { psi average. } \\
\text { Additional cores taken near } \\
\text { failed locations. }\end{array}$ & Issue \\
\hline 87 & $9 / 22 / 1971$ & Kaolite & 101 & $\begin{array}{l}\text { Surveying surface of kaolite, } \\
\text { lowering high spots and } \\
\text { filling low spots, taking } \\
\text { additional cores. }\end{array}$ & Construction \\
\hline 88 & $9 / 22 / 1971$ & Kaolite & 102 & $\begin{array}{l}\text { Pouring of Kaolite to begin } \\
\text { on swings. }\end{array}$ & Construction \\
\hline 89 & 9/23/1971 & Kaolite & 101 & $\begin{array}{l}3 \text { inch pour made on } 101 \text {, } \\
\text { numerous cracks noted. }\end{array}$ & Issue \\
\hline
\end{tabular}




\begin{tabular}{|c|c|c|c|c|c|}
\hline Reference & Date & Log & Tank & Comments & Event \\
\hline 90 & 9/23/1971 & Kaolite & 102 & Completed section 11 . & \\
\hline 91 & 9/23/1971 & Kaolite & 101 & $\begin{array}{l}\text { Leveling } 101 \text {. Moving } \\
\text { bottom steel into place. B\&W } \\
\text { rep onsite and not in favor of } \\
\text { vibrating kaolite. }\end{array}$ & \\
\hline 92 & 9/24/1971 & Kaolite & 102 & $\begin{array}{l}\text { Photographer in TK } 102 \text {. } \\
\text { Floor plate dropped under the } \\
\text { weight of Kaolite in section } \\
\text { 3. Blister in the floor plate in } \\
\text { sections } 1 \text { and } 2 \text { noted also. }\end{array}$ & Issue \\
\hline 93 & 9/24/1971 & Kaolite & 102 & $\begin{array}{l}\text { Steel plates buckled down } \\
3 / 8 \text { inch on section } 2 \text { near } \\
\text { tank center. }\end{array}$ & Issue \\
\hline 94 & 9/27/1971 & Kaolite & 101 & $\begin{array}{l}\text { Curing protection removed } \\
\text { from pourbacks and } \\
\text { construction loads being } \\
\text { supported. }\end{array}$ & \\
\hline 95 & 9/28/1971 & Kaolite & 102 & $\begin{array}{l}\text { Temp in } 102 \text { tent low of } 53 \mathrm{~F} \text {, } \\
\text { limit is } 50 \mathrm{~F} \text { per procedure, } \\
\text { more heaters to be used. }\end{array}$ & \\
\hline 96 & 9/28/1971 & Kaolite & 101 & $\begin{array}{l}\text { Taking core from section } 28 \\
\text { on TK } 101 .\end{array}$ & \\
\hline 97 & 9/28/1971 & Kaolite & 102 & $\begin{array}{l}\text { Rain squall, leak into tent on } \\
\text { section } 17 \text {. }\end{array}$ & Issue \\
\hline 98 & 9/29/1971 & Kaolite & 102 & $\begin{array}{l}\text { Low temp in } 102 \text { tent was } \\
52 F \text {, not enough kaolite is } \\
\text { left to finish tk } 102 \text {. }\end{array}$ & Issue \\
\hline 99 & 9/29/1971 & Construction & 101 & $\begin{array}{l}\text { Welding on } 101 \text { primary } \\
\text { bottom, general note that an } \\
\text { effort must be made to } \\
\text { improve radiography quality. }\end{array}$ & Construction / Issue \\
\hline 100 & 9/30/1971 & Kaolite & 102 & $\begin{array}{l}\text { Low temp of } 53 \mathrm{~F} \text {, will add } \\
\text { heaters and additional kaolite } \\
\text { located. }\end{array}$ & \\
\hline 101 & 9/30/1971 & Kaolite & 102 & $\begin{array}{l}\text { Swing shift to be laid off due } \\
\text { to lack of kaolite. Sections } 24 \\
\text { and } 26 \text { completed. Heating } \\
\text { problems continue. }\end{array}$ & \\
\hline 102 & $10 / 1 / 1971$ & Kaolite & 102 & $\begin{array}{l}\text { Low temp was } 79 \mathrm{~F} \text {, all } \\
\text { heaters working. }\end{array}$ & \\
\hline
\end{tabular}




\begin{tabular}{|c|c|c|c|c|c|}
\hline Reference & Date & Log & Tank & Comments & Event \\
\hline 103 & $10 / 4 / 1971$ & Kaolite & 102 & $\begin{array}{l}\text { Semi with Kaolite } 2000 \\
\text { arrived, requested it be } \\
\text { protected. }\end{array}$ & \\
\hline 104 & 10/5/1971 & Kaolite & 102 & $\begin{array}{l}\text { Section } 28 \text { badly cracked, to } \\
\text { be chipped out and repaired, } \\
\text { new kaolite not protected, } \\
\text { contractor problems noted. }\end{array}$ & Issue \\
\hline 105 & $10 / 6 / 1971$ & Kaolite & 102 & $\begin{array}{l}\text { Last section completed and } \\
28 \text { sections core drilled. }\end{array}$ & Construction \\
\hline 106 & 10/7/1971 & Kaolite & 102 & Repair core drill holes. & \\
\hline 107 & 10/8/1971 & Kaolite & 102 & $\begin{array}{l}\text { Curing of TK } 102 \text { kaolite } \\
\text { completed, canvas tent } \\
\text { removed. }\end{array}$ & \\
\hline 108 & 10/8/1971 & Construction & 101 & $\begin{array}{l}\text { Welding primary knuckle } \\
\text { sections. }\end{array}$ & Construction \\
\hline 109 & 10/11/1971 & Kaolite & 101 & $\begin{array}{l}\text { Located equipment that can } \\
\text { be used to core drill under the } \\
\text { raised bottom of TK } 101 \text {. }\end{array}$ & Issue \\
\hline 110 & $10 / 12 / 1971$ & Kaolite & 102 & $\begin{array}{l}\text { Survey crew establishing } \\
\text { elevation on 102, TBM is } \\
618.93 \text {. }\end{array}$ & Construction \\
\hline 111 & $10 / 12 / 1971$ & Construction & 102 & $\begin{array}{l}\text { Placing primary plates into } \\
\text { 102, new radiograph machine } \\
\text { onsite, } 700-800 \mathrm{ft} \text { behind } \\
\text { schedule. }\end{array}$ & Construction \\
\hline 112 & $10 / 13 / 1971$ & Kaolite & 102 & Filling records. & \\
\hline 113 & 10/13/1971 & Construction & & $\begin{array}{l}\text { Repair rate (based 3"per } \\
\text { reject radiograph) for } 101 \\
\text { secondary bottom } 3.4 \%, 102 \\
\text { secondary bottom } 1.9 \% \text {. }\end{array}$ & Construction \\
\hline 114 & 10/18/1971 & Construction & 101 & $\begin{array}{l}\text { Welding primary bottom and } \\
\text { repairing secondary. }\end{array}$ & \\
\hline 115 & 10/18/1971 & Construction & 102 & $\begin{array}{l}\text { Welding 3rd ring on } \\
\text { secondary. }\end{array}$ & Construction \\
\hline 116 & 10/20/1971 & Construction & 101 & $\begin{array}{l}1 \text { inch thick plate being } \\
\text { welded. }\end{array}$ & Construction \\
\hline 117 & 10/26/1971 & Construction & 101 & $\begin{array}{l}\text { Primary bottom radiography } \\
\text { completed. }\end{array}$ & \\
\hline
\end{tabular}




\begin{tabular}{|c|c|c|c|c|c|}
\hline Reference & Date & Log & Tank & Comments & Event \\
\hline 118 & $10 / 27 / 1971$ & Construction & 101 & $\begin{array}{l}\text { Installation trusses on } \\
\text { primary bottom. }\end{array}$ & \\
\hline 119 & 11/1/1971 & Kaolite & 101 & $\begin{array}{l}\text { Core drilling section in } \\
\text { TK101 that were less than } \\
130 \text { psi , 1-B, 3-B, 11-B, 12- } \\
\text { A\&B, 15-B, 16 -A\&B, 18- } \\
\text { A\&B, 22-B, 24-B, 28-B, 31- } \\
\text { A, 32-A, 8-B, Total } 16 \text { cores. }\end{array}$ & Issue \\
\hline 120 & 11/1/1971 & Construction & & $\begin{array}{l}\text { Water has collected in the } \\
\text { annulus and soaked into the } \\
\text { kaolite, responsibility for } \\
\text { kaolite protection not } \\
\text { defined. }\end{array}$ & Issue \\
\hline 121 & $11 / 2 / 1971$ & Kaolite & 102 & $\begin{array}{l}33 \text { pours made on TK } 102 \\
\text { and } 32 \text { pours made on TK } \\
\text { 101, additional pour made at } \\
\text { center of tank per no. CS- } \\
\text { 370-1. }\end{array}$ & \\
\hline 122 & $11 / 2 / 1971$ & Kaolite & 101 & $\begin{array}{l}\text { Elevation at Tank } 101 \text { was } \\
\text { 618.96. }\end{array}$ & Construction \\
\hline 123 & $11 / 4 / 1971$ & Kaolite & 102 & $\begin{array}{l}\text { Increasing width of air slots } \\
\text { and cutting out areas for re- } \\
\text { pouring. }\end{array}$ & Issue \\
\hline 124 & 11/4/1971 & Kaolite & 101 & $\begin{array}{l}\text { Will lower primary on Tk101 } \\
\text { on } 11 / 7 \text {. }\end{array}$ & \\
\hline 125 & 11/5/1971 & Kaolite & 102 & $\begin{array}{l}\text { Kaolite cutouts keyed and } \\
\text { repoured. Heat during cure is } \\
\text { requested. }\end{array}$ & \\
\hline 126 & $11 / 6 / 1971$ & Kaolite & 102 & $\begin{array}{l}\text { All Kaolite repairs } \\
\text { completed. }\end{array}$ & Construction \\
\hline 127 & 11/8/1971 & Kaolite & 101 & $\begin{array}{l}\text { Some areas in TK } 101 \text { under } \\
\text { cribbing may need repair, } \\
\text { gouged out areas noted in at } \\
\text { the center of the secondary } \\
\text { tanks bottom where center } \\
\text { post was. Repairs requested. }\end{array}$ & Issue \\
\hline 128 & $11 / 8 / 1971$ & Construction & 101 & $\begin{array}{l}\text { Mag particles tests on } \\
\text { primary and secondary sump } \\
\text { area, all acceptable. }\end{array}$ & \\
\hline 129 & 11/9/1971 & Kaolite & 101 & $\begin{array}{l}\text { Kaolite inspected and no } \\
\text { problems noted in lowering } \\
\text { of primary tank. }\end{array}$ & \\
\hline
\end{tabular}


RPP-RPT-54818, Rev. 0

\begin{tabular}{|c|c|c|c|c|c|}
\hline Reference & Date & Log & Tank & Comments & Event \\
\hline 130 & 11/9/1971 & Construction & 101 & $\begin{array}{l}\text { Primary bottom lowered, no } \\
\text { problems. }\end{array}$ & Construction \\
\hline 131 & $11 / 10 / 1971$ & Construction & 101 & $\begin{array}{l}\text { Welding on } 4 \text { th ring of } \\
\text { secondary. }\end{array}$ & \\
\hline 132 & $11 / 10 / 1971$ & Construction & 102 & Welding on primary bottom. & \\
\hline 133 & $11 / 12 / 1971$ & Construction & 101 & $\begin{array}{l}\text { Work to correct plumbness } \\
\text { initiated. }\end{array}$ & \\
\hline 134 & $11 / 15 / 1971$ & Construction & 101 & $\begin{array}{l}\text { JAJ began concrete work on } \\
101 .\end{array}$ & Construction \\
\hline 135 & $11 / 18 / 1971$ & Construction & 102 & $\begin{array}{l}\text { Area 6-7 (seam C-1) } \\
\text { determined to be a cold lap. }\end{array}$ & Issue \\
\hline 136 & 11/19/1971 & Construction & & $\begin{array}{l}\text { Extensive mag particle } \\
\text { testing is becoming apparent } \\
\text { for the AZ tanks. }\end{array}$ & Issue \\
\hline 137 & $11 / 22 / 1971$ & Construction & 101 & $\begin{array}{l}\text { Primary bottom checked for } \\
\text { deformation and found to be } \\
\text { acceptable without flattening. }\end{array}$ & Issue \\
\hline 138 & $11 / 22 / 1971$ & Construction & 102 & $\begin{array}{l}\text { Area previously determined } \\
\text { to be a cold lap ( } 6-7 \text { (seam } \\
\text { C-1))verified by mag particle } \\
\text { inspection. }\end{array}$ & Issue \\
\hline 139 & $11 / 23 / 1971$ & Construction & 101 & $\begin{array}{l}\text { 1st lift of concrete being } \\
\text { placed, vitro to inspect. }\end{array}$ & Construction \\
\hline 140 & $11 / 23 / 1971$ & Construction & 101 & $\begin{array}{l}101 \text { secondary weld reject } \\
\text { rate is } 1.9 \% \text {, as girth weld } \\
1.3 \% \text {, vertical welds } 4.8 \% \text {. }\end{array}$ & \\
\hline 141 & $11 / 29 / 1971$ & Construction & 102 & $\begin{array}{l}\text { Cold lap noted examined by } \\
\text { ARCHO, suspect to be mill } \\
\text { scale. Area sandblasted and } \\
\text { re-examined and determined } \\
\text { to be relevant. Area to be } \\
\text { repaired and reexamined. }\end{array}$ & Issue \\
\hline 142 & $12 / 5 / 1971$ & Construction & 101 & $\begin{array}{l}\text { Second lift of concrete } \\
\text { placed. }\end{array}$ & Construction \\
\hline 143 & 12/6/1971 & Construction & 102 & $\begin{array}{l}\text { Installing trusses on } 102 \\
\text { primary to lower bottom. }\end{array}$ & \\
\hline 144 & 12/7/1971 & Construction & 102 & $\begin{array}{l}\text { Cold lap area ground down } \\
\text { and re-inspected. }\end{array}$ & \\
\hline 145 & 12/9/1971 & Construction & 101 & Third lift of concrete placed. & Construction \\
\hline
\end{tabular}




\begin{tabular}{|c|c|c|c|c|c|}
\hline Reference & Date & Log & Tank & Comments & Event \\
\hline 146 & $12 / 15 / 1971$ & Construction & & $\begin{array}{l}\text { Noted that water in annulus } \\
\text { must be kept pumped out. }\end{array}$ & Issue \\
\hline 147 & $12 / 15 / 1971$ & Construction & & $\begin{array}{l}\text { Weld reject rate is given TK } \\
101 \text { secondary girth } 1.3 \% \text {, } \\
\text { vertical } 4.8 \% \text {, TK } 102 \\
\text { secondary girth } 1.4 \% \text {, } \\
\text { vertical } 1.8 \% \text {. }\end{array}$ & \\
\hline 148 & $12 / 16 / 1971$ & Construction & & $\begin{array}{l}\text { Some damage may have } \\
\text { occurred to kaolite due to } \\
\text { freezing, ice formation in } 101 \\
\text { primary bottom. }\end{array}$ & Issue \\
\hline 149 & $12 / 17 / 1971$ & Construction & 102 & $\begin{array}{l}\text { Heaters placed under } 102 \\
\text { bottom to avoid future } \\
\text { freezing. }\end{array}$ & \\
\hline 150 & $12 / 21 / 1971$ & Construction & 102 & $\begin{array}{l}\text { Damaged kaolite being } \\
\text { removed from TK } 102 \text { where } \\
\text { necessary. }\end{array}$ & Issue \\
\hline 151 & $12 / 22 / 1971$ & Construction & 102 & $\begin{array}{l}\text { Magnetic particle testing in } \\
\text { secondary sump area shows } \\
\text { no damage from center post. }\end{array}$ & Issue \\
\hline 152 & $12 / 24 / 1971$ & Construction & & $\begin{array}{l}\text { Kaolite temperature will be } \\
\text { checked over holiday. }\end{array}$ & \\
\hline 153 & $12 / 28 / 1971$ & Construction & 102 & $\begin{array}{l}\text { Second lift of concrete } \\
\text { placed, } 102 \text { primary tank } \\
\text { bottom lowered. }\end{array}$ & Construction \\
\hline 154 & $12 / 29 / 1971$ & Construction & 102 & $\begin{array}{l}\text { Trusses being removed, } \\
\text { requiring opening of tent, } \\
\text { concern about maintaining } \\
\text { kaolite. }\end{array}$ & \\
\hline 155 & 1/4/1972 & Construction & 101 & $\begin{array}{l}\text { Placing the 3rd shell ring on } \\
101 \text { primary tank, magnetic } \\
\text { particle testing on exterior of } \\
101 \text { Primary tank. }\end{array}$ & \\
\hline 156 & 1/4/1972 & Construction & 102 & $\begin{array}{l}\text { Weld repair in progress on } \\
102 \text { primary bottom. }\end{array}$ & \\
\hline 157 & 1/5/1972 & Construction & 101 & $\begin{array}{l}\text { Leak detection riser, } \\
\text { fabricated to unapproved } \\
\text { specification readied for } \\
\text { installation. NCR initiated. } \\
\text { Sump needs to be cleaned } \\
\text { out. }\end{array}$ & Issue \\
\hline
\end{tabular}




\begin{tabular}{|c|c|c|c|c|c|}
\hline Reference & Date & $\log$ & Tank & Comments & Event \\
\hline 158 & 1/5/1972 & Construction & & $\begin{array}{l}\text { PDM to designate footage to } \\
\text { be left uncovered daily buy } \\
\text { JAJ to permit radiography. } \\
\text { PDM will work inside tank } \\
\text { during backfill operation by } \\
\text { using portable welding } \\
\text { machines. }\end{array}$ & \\
\hline 159 & 1/7/1972 & Construction & 102 & $\begin{array}{l}\text { Pouring 3rd lift on } 102 \\
\text { concrete. }\end{array}$ & Construction \\
\hline 160 & 1/10/1972 & Construction & 102 & $\begin{array}{l}\text { Remainder of } 1 \text { st ring placed } \\
\text { on } 102 \text { primary. }\end{array}$ & Construction \\
\hline 161 & 1/11/1972 & Construction & & $\begin{array}{l}\text { Winds to } 60 \text { mph. Many } \\
\text { portions of canvas torn or } \\
\text { missing. }\end{array}$ & \\
\hline 162 & $1 / 13 / 1972$ & Construction & & $\begin{array}{l}\text { Insert plates for the access } \\
\text { holes on tanks } 101 \text { and } 102 \\
\text { were welded in place. }\end{array}$ & \\
\hline 163 & $1 / 13 / 1972$ & Construction & & $\begin{array}{l}\text { Concluded that time spent by } \\
\text { PDM on magnetic particle } \\
\text { testing of primary bottom } \\
\text { must be monitored. }\end{array}$ & \\
\hline 164 & 1/14/1972 & Construction & & $\begin{array}{l}\text { Radiographs of insert plates } \\
\text { show welds are unacceptable, } \\
\text { not done per DVR and } \\
\text { increased chance of cracking } \\
\text { and will require magnetic } \\
\text { particle testing as a second } \\
\text { test. Repair completed by } \\
\text { noon and radiographed and } \\
\text { still not acceptable. Jones not } \\
\text { able to pour concrete in these } \\
\text { openings. }\end{array}$ & Issue \\
\hline 165 & $1 / 14 / 1972$ & Construction & & $\begin{array}{l}\text { Heat being maintained on } \\
\text { both tanks and the caisson. }\end{array}$ & \\
\hline 166 & 1/14/1972 & Construction & 102 & $\begin{array}{l}\text { TK } 102 \text { leak detection Riser } \\
\text { installed. }\end{array}$ & Construction \\
\hline 167 & 1/17/1972 & Construction & 102 & $\begin{array}{l}\text { Weld repairs on TK } 102 \\
\text { again rejected, weld repairs } \\
\text { on TK } 101 \text { accepted. } \\
\text { Magnetic particle testing also } \\
\text { acceptable. }\end{array}$ & Issue \\
\hline
\end{tabular}




\begin{tabular}{|c|c|c|c|c|c|}
\hline Reference & Date & Log & Tank & Comments & Event \\
\hline 168 & 1/18/1972 & Construction & 102 & $\begin{array}{l}\text { Final repair of TK } 102 \\
\text { secondary insert was } \\
\text { acceptable. Also magnetic } \\
\text { particle tested. }\end{array}$ & Issue \\
\hline 169 & 1/19/1972 & Construction & & $\begin{array}{l}\text { Placed concrete in } 101 \text { and } \\
102 \text { access holes, concrete } \\
\text { will be protected from } \\
\text { backfill by } 1 / 4 \text { inch plate and } \\
\text { angle iron re-enforcement. }\end{array}$ & \\
\hline 170 & 1/19/1972 & Construction & & $\begin{array}{l}\text { Began backfilling. } \\
\text { Cautioned contractor not to } \\
\text { approach the tanks ( } 8 \mathrm{ft} \\
\text { limit) with rigs over } 5 \text { ton. }\end{array}$ & \\
\hline 171 & $1 / 23 / 1972$ & Construction & 101 & $\begin{array}{l}\text { TK } 101 \text { was properly covered } \\
\text { to prevent rain from entering } \\
\text { the annulus, TK } 102 \text { was } \\
\text { previously covered. }\end{array}$ & Issue \\
\hline 172 & $1 / 24 / 1972$ & Construction & & $\begin{array}{l}\text { Numerous amount of cracks } \\
\text { were noted in the concrete } \\
\text { cylinder walls. }\end{array}$ & \\
\hline 173 & $1 / 25 / 1972$ & Construction & & $\begin{array}{l}\text { Weld repairs on TK } 101 \text { and } \\
\text { welding } 102 \text { verticals. Heat } \\
\text { be maintained and monitored. }\end{array}$ & \\
\hline 174 & $1 / 26 / 1972$ & Construction & & $\begin{array}{l}9^{\circ} \mathrm{F} \text {, work stopped at } 9 \text { am (- } \\
2^{\circ} \mathrm{F} \text { two days later and no } \\
\text { stoppage). }\end{array}$ & Issue \\
\hline 175 & 2/1/1972 & Construction & 101 & $\begin{array}{l}\text { Magnetic particle testing } \\
\text { initiated on } 101 \text { primary } \\
\text { bottom, determined to be not } \\
\text { effective and efficient, } \\
\text { decided not to continue. }\end{array}$ & \\
\hline 176 & 2/2/1972 & Construction & 102 & $\begin{array}{l}\text { PDM to begin magnetic } \\
\text { particle testing on } 102 \\
\text { primary skirt. }\end{array}$ & \\
\hline 177 & 2/4/1972 & Construction & 102 & $\begin{array}{l}\text { 2nd ring placed on TK } 102 \\
\text { primary, heat being } \\
\text { maintained for protection of } \\
\text { kaolite. }\end{array}$ & Construction \\
\hline 178 & 2/7/1972 & Construction & & $\begin{array}{l}\text { Stress relieving equipment } \\
\text { delivered, magnetic particle } \\
\text { testing of } 102 \text { primary skirt. }\end{array}$ & \\
\hline
\end{tabular}




\begin{tabular}{|c|c|c|c|c|c|}
\hline Reference & Date & Log & Tank & Comments & Event \\
\hline 179 & 2/8/1972 & Construction & & $\begin{array}{l}\text { Upper knuckle sections } \\
\text { placed on } 101 \text { primary. }\end{array}$ & \\
\hline 180 & 2/8/1972 & Construction & & $\begin{array}{l}\text { Told to cover re-stl with } \\
\text { heavy blankets for safety. } \\
\text { Suggested it may provide a } \\
\text { fire hazard, blankets placed. }\end{array}$ & \\
\hline 181 & 2/10/1972 & Construction & 102 & $\begin{array}{l}\text { Fire discovered in TK } 102 . \\
\text { Damage limited to canvas } \\
\text { material used for heating } \\
\text { kaolite and wood scaffolding. } \\
\text { Fire department thoroughly } \\
\text { wetted material. }\end{array}$ & Issue \\
\hline 182 & 2/11/1972 & Construction & 101 & $\begin{array}{l}\text { Center insert plate of } 101 \\
\text { primary magnetic particle } \\
\text { tested to allow placement of } \\
\text { center support column. }\end{array}$ & \\
\hline 183 & 2/13/1972 & Construction & 101 & $\begin{array}{l}\text { Most of the tarps have blown } \\
\text { off the } 101 \text { tank, but rain not } \\
\text { expected. }\end{array}$ & Issue \\
\hline 184 & 2/14/1972 & Construction & 101 & $\begin{array}{l}\text { No longer required to cover } \\
\text { TK } 101 \text { on routine basis. }\end{array}$ & \\
\hline 185 & 2/16/1972 & Construction & & $\begin{array}{l}\text { Long account is provided } \\
\text { regarding the magnetic } \\
\text { particle testing, primary } \\
\text { dealing with proper surface } \\
\text { preparation prior to testing, } \\
\text { decided not to power brush, } \\
\text { but remove loose rust and } \\
\text { scale. }\end{array}$ & \\
\hline 186 & 2/18/1972 & Construction & & $\begin{array}{l}\text { Heat being supplied to } \\
\text { annulus to keep it dry as } \\
\text { snow is falling. }\end{array}$ & \\
\hline 187 & 2/19/1972 & Construction & 102 & $\begin{array}{l}\text { Fire in TK } 102 \text { annulus, } \\
\text { welding sparks ignited gas } \\
\text { under plywood scaffolding in } \\
\text { annulus bottom. The fire } \\
\text { department was summoned } \\
\text { immediately; however, the } \\
\text { fire was extinguished by the } \\
\text { time of their arrival. }\end{array}$ & Issue \\
\hline
\end{tabular}




\begin{tabular}{|c|c|c|c|c|c|}
\hline Reference & Date & Log & Tank & Comments & Event \\
\hline 188 & 2/21/1972 & Construction & & $\begin{array}{l}\text { Received letter on cleaning in } \\
\text { preparation for Mag particle } \\
\text { testing, where cleaning is } \\
\text { only to be done in areas } \\
\text { directed by commission. }\end{array}$ & \\
\hline 189 & 2/22/1972 & Construction & & $\begin{array}{l}\text { J Slaughter and Bob } \\
\text { Wendleant (PDM-Seattle) } \\
\text { discussed magnetic particle } \\
\text { testing, work to begin as soon } \\
\text { as possible. }\end{array}$ & \\
\hline 190 & 2/23/1972 & Construction & 101 & $\begin{array}{l}\text { First section of dome plate } \\
\text { placed on } 101 \text { primary. }\end{array}$ & Construction \\
\hline 191 & 2/23/1972 & Construction & & $\begin{array}{l}\text { Discussion with PDM on } \\
\text { how to clean and prep the } \\
\text { steel for magnetic particle } \\
\text { testing to resolve concerns. }\end{array}$ & Issue \\
\hline 192 & 2/23/1972 & Construction & & $\begin{array}{l}\text { Long QA program change } \\
\text { discussion. }\end{array}$ & \\
\hline 193 & 2/24/1972 & Construction & & $\begin{array}{l}\text { Cleaning of primary bottom } \\
\text { plate }(1 / 2 \text { of center plate } \\
\text { completed) as first area for } \\
\text { magnetic particle testing. }\end{array}$ & \\
\hline 194 & 2/28/1972 & Construction & & $\begin{array}{l}\text { PDM man permanently } \\
\text { assigned to magnetic particle } \\
\text { testing until completion. } \\
\text { Installation of reinforcement } \\
\text { for kaolite retainer ring } \\
\text { initiated. 3rd horizontal } \\
\text { being welded on } 102 \\
\text { primary. }\end{array}$ & \\
\hline 195 & 2/29/1972 & Construction & 101 & $\begin{array}{l}\text { Magnetic particle testing } \\
\text { resumed in } 101 \text { primary tank. } \\
\text { All scaffolding removed from } \\
101 \text { primary. }\end{array}$ & \\
\hline 196 & 3/1/1972 & Construction & & $\begin{array}{l}\text { Rain and snow. Notified G. } \\
\text { adolf to remove water from } \\
\text { the annulus should it become } \\
\text { excessive. Heat should be } \\
\text { turned on during rainy } \\
\text { periods. }\end{array}$ & Issue \\
\hline 197 & 3/2/1972 & Construction & & $\begin{array}{l}\text { Discussed modification of the } \\
\text { re-enforcement pads for } \\
\text { retainer ring. }\end{array}$ & \\
\hline
\end{tabular}




\begin{tabular}{|c|c|c|c|c|c|}
\hline Reference & Date & Log & Tank & Comments & Event \\
\hline 198 & 3/3/1972 & Construction & & $\begin{array}{l}\text { Magnetic particle testing } \\
\text { resumed in } 101 \text { primary tank. } \\
\text { Installed 4th primary ring on } \\
102 \text { tank. }\end{array}$ & Construction \\
\hline 199 & 3/6/1972 & Construction & & $\begin{array}{l}\text { 2nd man assigned to } \\
\text { magnetic particle testing. }\end{array}$ & \\
\hline 200 & 3/7/1972 & Construction & 101 & $\begin{array}{l}\text { Laying out dome penetrations } \\
\text { on } 101 \text { tank. Welding on } \\
\text { repair and final dome section } \\
\text { which was placed today. }\end{array}$ & \\
\hline 201 & 3/8/1972 & Construction & & $\begin{array}{l}\text { Survey crew checking } \\
\text { coordinates for } 101 \text { dome } \\
\text { penetrations. Discussed } \\
\text { removing sections of the } \\
\text { backing strip on the dome } \\
\text { sections to allow the flashing } \\
\text { to closely joined to the } \\
\text { primary tank. }\end{array}$ & \\
\hline 202 & 3/9/1972 & Construction & & $\begin{array}{l}\text { Additional welding needed } \\
\text { on retainer ring as specified } \\
\text { in design change (ES-647- } \\
\text { H1). Backing strip to be } \\
\text { removed where flashing strip } \\
\text { was to be installed. }\end{array}$ & \\
\hline 203 & 3/10/1972 & Construction & 101 & $\begin{array}{l}\text { Magnetic particle testing } \\
\text { continues in } 101 \text { primary } \\
\text { along with weld repairs. }\end{array}$ & \\
\hline 204 & 3/11/1972 & Construction & 101 & $\begin{array}{l}\text { PDM now has } 3 \text { magnetic } \\
\text { particle men present doing } \\
\text { inspection in } 101 \text { primary. }\end{array}$ & \\
\hline 205 & 3/12/1972 & Construction & 101 & $\begin{array}{l}\text { Magnetic particle testing in } \\
101 \text { primary continues with } 3 \\
\text { men present. Some small } \\
\text { areas of bottom are wet. }\end{array}$ & \\
\hline 206 & 3/13/1972 & Construction & & $\begin{array}{l}\text { Heaters and plywood } \\
\text { removed from the annulus, in } \\
\text { view of the warm } \\
\text { temperatures and to facilitate } \\
\text { removal of water from the } \\
\text { annulus. }\end{array}$ & Issue \\
\hline
\end{tabular}




\begin{tabular}{|c|c|c|c|c|c|}
\hline Reference & Date & Log & Tank & Comments & Event \\
\hline 207 & 3/13/1972 & Construction & & $\begin{array}{l}\text { A boilermaker was assigned } \\
\text { to grind magnetic particle } \\
\text { indications to determine if } \\
\text { they are relevant. Indications } \\
\text { not removed by grinding are } \\
\text { set aside for further } \\
\text { evaluation. }\end{array}$ & \\
\hline 208 & 3/14/1972 & Construction & 102 & $\begin{array}{l}\text { Indications from mag particle } \\
\text { testing were ground some } \\
\text { and found to be relevant. } \\
\text { Areas of varying widths } \\
\text { could be peeled off the } \\
\text { surface. Later found that } \\
\text { these lamination type } \\
\text { discontinuities could be } \\
\text { removed by surface grinding } \\
\text { to a depth not to exceed } 1 / 16 \\
\text { inch. Ground area retested } \\
\text { and no indications found. If } \\
\text { the discontinuities are no } \\
\text { more serious, there should be } \\
\text { no concern testing the shell } \\
\text { rings. }\end{array}$ & Issue \\
\hline 209 & $3 / 15 / 1972$ & Construction & & $\begin{array}{l}\text { Meeting to resolve time } \\
\text { differences for mag particle } \\
\text { testing and erection delay. } \\
\text { All issues resolved. }\end{array}$ & \\
\hline 210 & 3/16/1972 & Construction & 102 & $\begin{array}{l}\text { Back-gouging the L- } 1 \text { seam } \\
\text { of the } 102 \text { primary, severe } \\
\text { plate lamination revealed. } \\
\text { Present in two plates in top } \\
\text { rings, suggestion made to UT } \\
\text { these are using Westinghouse } \\
\text { personnel. }\end{array}$ & Issue \\
\hline 211 & 3/17/1972 & Construction & 102 & $\begin{array}{l}\text { Met with Westinghouse, } \\
\text { ARCHO, AEC, and PDM } \\
\text { personnel to discuss UT. } \\
\text { Magnetic particle testing on } \\
\text { TK } 102 \text { primary bottom. }\end{array}$ & \\
\hline 212 & 3/20/1972 & Construction & 101 & $\begin{array}{l}\text { Provided PDM with a list of } \\
\text { radiographs required to } \\
\text { complete the } 101 \text { primary } \\
\text { shell. }\end{array}$ & \\
\hline
\end{tabular}




\begin{tabular}{|c|c|c|c|c|c|}
\hline Reference & Date & Log & Tank & Comments & Event \\
\hline 213 & 3/21/1972 & Construction & 102 & $\begin{array}{l}\text { Asked to have Westinghouse } \\
\text { perform ultrasonic testing on } \\
\text { the TK } 102 \text { primary plates } \\
\text { known to contain } \\
\text { laminations. Upper knuckles } \\
\text { placed on } 102 \text { primary } \\
\text { plates with lamination will } \\
\text { not be welded. }\end{array}$ & Issue \\
\hline 214 & 3/21/1972 & Construction & 101 & $\begin{array}{l}\text { All radiographs have been } \\
\text { received on the } 101 \text { primary } \\
\text { tank and one repair remains. } \\
\text { Will start insulating Tk } 101 \\
\text { tomorrow. }\end{array}$ & Construction \\
\hline 215 & 3/21/1972 & Construction & & $\begin{array}{l}\text { Notified PDM that } 1 / 4 \text { inch } \\
\text { space must exist between the } \\
\text { kaolite stop and the } \\
\text { secondary tank. }\end{array}$ & \\
\hline 216 & 3/21/1972 & Construction & & $\begin{array}{l}\text { Obvious confusion and } \\
\text { misinterpretation of the } \\
\text { ultrasonic test performed last } \\
\text { Friday. Intend to clarify when } \\
\text { subsequent testing is } \\
\text { performed. }\end{array}$ & \\
\hline 217 & $3 / 22 / 1972$ & Construction & 101 & $\begin{array}{l}\text { PDM removed kaolite "stop" } \\
\text { at bottom of the retainer } \\
\text { band. Requested E.S. Davis } \\
\text { assign inspector to make } \\
\text { evaluation of Kaolite at this } \\
\text { time. Accepted primary } \\
\text { radiographs on } 101 \text { primary } \\
\text { today, all work and } \\
\text { documentation complete. }\end{array}$ & \\
\hline 218 & 3/23/1972 & Construction & 101 & $\begin{array}{l}\text { E.S Davis personally } \\
\text { examined the condition of the } \\
\text { kaolite (report on file). First } \\
\text { insulation placed in annulus. }\end{array}$ & Construction \\
\hline 219 & 3/23/1972 & Construction & 102 & $\begin{array}{l}\text { Bill Armstrong requested that } \\
\text { UT on the shell plates (4th } \\
\text { Ring) be IAW ASTM A435. } \\
\text { This will require additional } \\
\text { UT and cost. J. Slaughter } \\
\text { notified and accepted } \\
\text { additional cost. }\end{array}$ & Issue \\
\hline
\end{tabular}




\begin{tabular}{|c|c|c|c|c|c|}
\hline Reference & Date & Log & Tank & Comments & Event \\
\hline 220 & 3/24/1972 & Construction & 102 & $\begin{array}{l}\text { Air-arc gouging on the 4th } \\
\text { Shell ring in TK102 primary } \\
\text { disclosed a 3rd plate with } \\
\text { lamination at the edge. Work } \\
\text { halted on this plate. } \\
\text { Westinghouse personnel on } \\
\text { site to UT plates. }\end{array}$ & Issue \\
\hline 221 & 3/27/1972 & Construction & 102 & $\begin{array}{l}\text { Now } 4 \text { plates of the } 102 \\
\text { primary } 4 \text { th shell ring are } \\
\text { found to contain laminations } \\
\text { after air-arc gouging. }\end{array}$ & Issue \\
\hline 222 & 3/28/1972 & Construction & 102 & $\begin{array}{l}\text { PDM attempted repair of } \\
\text { plate edge lamination using } \\
\text { PDM procedure RP-3. Arc- } \\
\text { gouged a small section (3 } \\
\text { inches long) adjacent the } \\
\text { weld which completely } \\
\text { separated from the other half } \\
\text { of the } 3 / 8 \text { " plate. Lamination } \\
\text { still visible in the parent } \\
\text { material } 3 / 4 \text { " from weld. } \\
\text { Similar conditions found in } \\
\text { other areas of plate. PDM } \\
\text { advised to not weld on } \\
\text { laminated edges. }\end{array}$ & Issue \\
\hline 223 & 3/29/1972 & Construction & 102 & $\begin{array}{l}\text { Work on laminated plates } \\
\text { halted by PDM, subject to } \\
\text { expert examination. } \\
\text { Recommendations given to } \\
\text { replace plates. Ready to } \\
\text { place primary plates on } 102 \\
\text { dome. }\end{array}$ & \\
\hline 224 & 3/30/1972 & Construction & 102 & $\begin{array}{l}\text { ARCHO conducted UT on } \\
\text { one of the laminated plates. } \\
\text { PDM in favor of replacing } \\
\text { entire plates. Letter to be } \\
\text { forwarded to commission } \\
\text { with alternatives. }\end{array}$ & Issue \\
\hline 225 & 3/30/1972 & Construction & 101 & $\begin{array}{l}\text { Begin final inspection of } 101 \\
\text { primary bottom plates. }\end{array}$ & \\
\hline 226 & 3/31/1972 & Construction & 102 & $\begin{array}{l}\text { John Slaughter said } \\
\text { laminated plates must be } \\
\text { replaced and informed PDM. } \\
\text { Mr. Kligfiled request more } \\
\text { information. }\end{array}$ & Issue \\
\hline
\end{tabular}




\begin{tabular}{|c|c|c|c|c|c|}
\hline Reference & Date & Log & Tank & Comments & Event \\
\hline 227 & 3/31/1972 & Construction & 101 & $\begin{array}{l}\text { Final inspection of TK } 101 \\
\text { primary before stress relief, } \\
\text { areas of attention marked for } \\
\text { PDM. }\end{array}$ & Construction \\
\hline 228 & 4/4/1972 & Construction & 102 & $\begin{array}{l}\text { PDM says } 4 \text { plates ordered } \\
\text { from mill (A-55-60) and } \\
\text { should arrive near April } 16^{\text {th }} \text {. }\end{array}$ & \\
\hline 229 & 4/5/1972 & Construction & 102 & $\begin{array}{l}\text { Magnetic particle testing still } \\
\text { In progress in TK } 102 \\
\text { primary. }\end{array}$ & \\
\hline 230 & 4/6/1972 & Construction & 101 & $\begin{array}{l}\text { Jay Varvel and D Koreis } \\
\text { assigned as 2nd and 3rd shift } \\
\text { inspectors for stress relief. }\end{array}$ & \\
\hline 231 & 4/7/1972 & Construction & 101 & $\begin{array}{l}\text { Main Burners started as 7:25 } \\
\text { pm. A separate stress } \\
\text { relieving log book will be } \\
\text { used for coverage. }\end{array}$ & Construction \\
\hline 232 & 4/7/1972 & Stress Relief & 101 & $\begin{array}{l}\text { Main Burners started as } 7: 25 \\
\text { pm. Only burner D remained } \\
\text { on, burner C restarted at } \\
\text { lower gas flow rate. }\end{array}$ & \\
\hline 233 & 4/7/1972 & Stress Relief & & $\begin{array}{l}\text { All burners on at } 11 \text { pm, } \\
\text { Problems with \#3 recorder, } \\
\text { TC } 65 \text { over burner D is } 590^{\circ} \\
\text { @ } 1155 \text { pm, } 3 \text { burners on. }\end{array}$ & \\
\hline 234 & 4/8/1972 & Stress Relief & & $\begin{array}{l}\text { Bill Armstrong indicated } 8 \\
\text { hour heat up of kaolite could } \\
\text { start at } 12: 00 \text { am. All } \\
\text { thermocouples on the tank } \\
\text { read above } 250 \mathrm{~F} \text { except for } \\
\text { three on the outside tank } \\
\text { bottom ( } 230 \mathrm{~F}) \text {. } \\
\text { Thermocouples near burners } \\
\text { B\&D read } 20 \mathrm{~F} \text { above the } \\
600 \text { F required. }\end{array}$ & \\
\hline 235 & 4/8/1972 & Stress Relief & & $\begin{array}{l}\text { Two burners Ran most of the } \\
\text { night. }\end{array}$ & \\
\hline 236 & 4/8/1972 & Stress Relief & & $\begin{array}{l}\text { 4-12 shift notes numerous } \\
\text { problems, large differentials, } \\
\text { inability to control spread, } \\
\text { large overshoots above } \\
600^{\circ} \mathrm{F} \text {. }\end{array}$ & \\
\hline
\end{tabular}


RPP-RPT-54818, Rev. 0

\begin{tabular}{|c|c|c|c|c|c|}
\hline Reference & Date & Log & Tank & Comments & Event \\
\hline 237 & 4/8/1972 & Stress Relief & & $\begin{array}{l}12-8 \text { shift tries to increase } \\
\text { above } 600^{\circ} \mathrm{F} \text {, cannot evenly } \\
\text { and stops process. }\end{array}$ & Construction / Issue \\
\hline 238 & 4/10/1972 & Construction & 101 & $\begin{array}{l}\text { Cover plates removed to } \\
\text { allow entry, charts taken to } \\
\text { PGH. }\end{array}$ & \\
\hline 239 & 4/11/1972 & Construction & 101 & $\begin{array}{l}\text { Stress relieving system to be } \\
\text { modified by John Adams } \\
\text { (PDM engineer). }\end{array}$ & \\
\hline 240 & 4/12/1972 & Construction & 101 & $\begin{array}{l}\text { Modifications described to } \\
\text { stress relieving process, } \\
\text { including insulating primary } \\
\text { knuckle. }\end{array}$ & Construction \\
\hline 241 & 4/13/1972 & Construction & 101 & $\begin{array}{l}\text { Insulators placing material } \\
\text { against bottom primary } \\
\text { knuckle and in the air slots. }\end{array}$ & \\
\hline 242 & 4/13/1972 & Construction & & $\begin{array}{l}\text { PDM requested confirmation } \\
\text { of modification from } 1 \text { and } \\
1 / 2 \text { "H20 Minimum pressure } \\
\text { to a } 2 " \text { H20 pressure. }\end{array}$ & \\
\hline 243 & 4/18/1972 & Construction & 101 & $\begin{array}{l}\text { Vent tubes longer than } \\
\text { proposed and had to be cut } \\
\text { back, asked R. Nederhood to } \\
\text { examine thermocouple } \\
\text { location and possible } \\
\text { damage. }\end{array}$ & \\
\hline 244 & 4/19/1972 & Construction & 101 & $\begin{array}{l}\text { Nederhood informs that } \\
\text { location and conditions of } \\
\text { inside 'couples" appears } \\
\text { satisfactory. }\end{array}$ & \\
\hline 245 & 4/19/1972 & Construction & 101 & $\begin{array}{l}\text { 2nd Stress relieving started at } \\
\text { 3:30 pm, refer to SR logbook. }\end{array}$ & Construction \\
\hline 246 & 4/19/1972 & Stress Relief & 101 & $\begin{array}{l}\text { Official startup of stress } \\
\text { relieving (2nd occurrence) } \\
\text { was } 3: 30 \text { pm. PDM has } 12 \\
\text { hrs to reach } 600 \mathrm{~F}, 12 \mathrm{hr} \\
\text { period starts when lowest } \\
\text { couple reaches } 600 \mathrm{~F} \text {, when } \\
\text { 1st couple reaches } 600 \mathrm{~F} \\
\text { lowest must be } 400 \mathrm{~F} \text { ( } 200 \mathrm{~F} \\
\text { diff), At } 700 \mathrm{~F}, 1.5 \text { inches of } \\
\text { H20 required. }\end{array}$ & \\
\hline
\end{tabular}




\begin{tabular}{|c|c|c|c|c|c|}
\hline Reference & Date & Log & Tank & Comments & Event \\
\hline 247 & 4/19/1972 & Stress Relief & 101 & $\begin{array}{l}\text { At } 7: 30 \text { pm highest reading } \\
\text { was } 500 \mathrm{~F} \text { and lowest } 300 \mathrm{~F} \text {. } \\
\text { PDM attempting to decrease } \\
\text { differential. }\end{array}$ & \\
\hline 248 & 4/20/1972 & Stress Relief & 101 & $\begin{array}{l}\text { Stress relieving operation } \\
\text { going well, at } 11 \text { am PDM } \\
\text { started the } 3 \text { hr hold with } \\
\text { lowest thermocouple at } \\
\text { 1000F. TE-25, } 27 \text { and } 28 \\
\text { considered malfunctioning. }\end{array}$ & \\
\hline 249 & 4/20/1972 & Stress Relief & 101 & $\begin{array}{l}\text { At 11:40, lowest TC reading } \\
1050 F \text {, initiating a } 2 \text { hrs hold. } \\
\text { Soak period terminated at } \\
140 \text { pm and cooling started. } \\
\text { Cooling rate for } 1 \text { st two hrs } \\
\text { 40-70F/hr. }\end{array}$ & Construction \\
\hline 250 & 4/24/1972 & Construction & 101 & $\begin{array}{l}\text { Vacuum leak testing of } 101 \\
\text { primary and no indications } \\
\text { noted, Visual examination of } \\
\text { interior revealed no } \\
\text { abnormalities or damage. }\end{array}$ & Construction \\
\hline 251 & 4/24/1972 & Construction & & $\begin{array}{l}\text { Progress on M.P.T. is not } \\
\text { satisfactory and the } \\
\text { commission will be notified. }\end{array}$ & \\
\hline 252 & 4/24/1972 & Construction & 101 & $\begin{array}{l}\text { Began filling } 101 \text { tank for } \\
\text { hydrostatic test. }\end{array}$ & Construction \\
\hline 253 & 4/25/1972 & Construction & 102 & $\begin{array}{l}\text { Four shell ring plates arrived } \\
\text { to replace the laminated } \\
\text { plates found in the } 102 \\
\text { primary. }\end{array}$ & \\
\hline 254 & 4/26/1972 & Construction & 102 & $\begin{array}{l}\text { Welding and fit up of the } \\
\text { SRP-4 plates. Noted more } \\
\text { time should be allowed } 102 \\
\text { tank stress relieving for cool } \\
\text { down. }\end{array}$ & Issue \\
\hline 255 & 4/26/1972 & Construction & 102 & $\begin{array}{l}\text { Monitoring of the } 102 \text { tank } \\
\text { for prevention of kaolite } \\
\text { freezing was ended } \\
\text { yesterday. }\end{array}$ & \\
\hline 256 & 4/28/1972 & Construction & 101 & $\begin{array}{l}\text { Water level in } 101 \text { is at } 38 \mathrm{ft} \\
-11.5 \text { inches. Chalking of } \\
\text { seams to take place Monday. }\end{array}$ & Construction \\
\hline
\end{tabular}


RPP-RPT-54818, Rev. 0

\begin{tabular}{|c|c|c|c|c|c|}
\hline Reference & Date & Log & Tank & Comments & Event \\
\hline 257 & 5/1/1972 & Construction & 101 & $\begin{array}{l}\text { Installation of strain gages on } \\
101 \text { tank started today. }\end{array}$ & \\
\hline 258 & 5/1/1972 & Construction & 101 & $\begin{array}{l}\text { Examined chalked areas, } \\
\text { leakage noted in } 5 \text { areas on } \\
\text { dome section. }\end{array}$ & Construction / Issue \\
\hline 259 & 5/2/1972 & Construction & 101 & $\begin{array}{l}\text { Water level lowered to } \\
\text { facilitate repair of leaks } \\
\text { detected yesterday. }\end{array}$ & Issue \\
\hline 260 & 5/2/1972 & Construction & 102 & $\begin{array}{l}\text { Examined "new" plates that } \\
\text { has been arc-gouged for } \\
\text { welding and did not detect } \\
\text { any laminations. }\end{array}$ & \\
\hline 261 & 5/3/1972 & Construction & 101 & $\begin{array}{l}\text { Haunch sections being } \\
\text { installed on } 101 \text { secondary. }\end{array}$ & Construction \\
\hline 262 & 5/5/1972 & Construction & 102 & $\begin{array}{l}\text { Magnetic particle testing } \\
\text { completed on } 102 \text { primary } \\
\text { bottom. Welding on TK } 102 \\
\text { 4th primary shell ring. }\end{array}$ & \\
\hline 263 & $5 / 11 / 1972$ & Construction & 102 & $\begin{array}{l}\text { Final section of TK } 102 \\
\text { primary dome placed today. }\end{array}$ & Construction \\
\hline 264 & $5 / 12 / 1972$ & Construction & 102 & $\begin{array}{l}\text { Final radiography will be } \\
\text { completed this weekend as } \\
\text { final repairs are in progress. }\end{array}$ & \\
\hline 265 & 5/15/1972 & Construction & 102 & $\begin{array}{l}\text { Radiography of } 102 \text { Primary } \\
\text { tank complete and accepted } \\
\text { today. }\end{array}$ & Construction \\
\hline 266 & $5 / 15 / 1972$ & Construction & & $\begin{array}{l}\text { Omitted from log of } 5 / 11 \text {, } \\
\text { Examined stainless steel } \\
\text { dome penetration when } \\
\text { welding complete and found } \\
\text { acceptable. }\end{array}$ & \\
\hline 267 & $5 / 16 / 1972$ & Construction & 102 & $\begin{array}{l}\text { Visual examination of } 102 \\
\text { primary tank exterior. }\end{array}$ & \\
\hline 268 & 5/18/1972 & Construction & 102 & $\begin{array}{l}\text { Burner tubes and installation } \\
\text { of insulation continue on TK } \\
102 . \text { Vacuum box testing of } \\
102 \text { primary tank bottom } \\
\text { began. }\end{array}$ & \\
\hline
\end{tabular}




\begin{tabular}{|c|c|c|c|c|c|}
\hline Reference & Date & Log & Tank & Comments & Event \\
\hline 269 & 5/19/1972 & Construction & 102 & $\begin{array}{l}\text { Vacuum box testing } \\
\text { completed and all areas } \\
\text { accepted in } 102 \text { primary } \\
\text { bottom. }\end{array}$ & \\
\hline 270 & 5/23/1972 & Construction & 102 & $\begin{array}{l}\text { Final inspection made on } 102 \\
\text { primary interior, found } \\
\text { acceptable and ready for } \\
\text { stress relief, thermocouples } \\
\text { checked by R. Nederhood. }\end{array}$ & Construction \\
\hline 271 & 5/24/1972 & Construction & 102 & $\begin{array}{l}\text { Final preparations for stress } \\
\text { relieving completed today, } \\
\text { refer to stress relieving log } \\
\text { for Wed } 5 / 24 / 72 \text { to Fri } \\
5 / 26 / 72 \text {. }\end{array}$ & \\
\hline 272 & 5/24/1972 & Stress Relief & 102 & $\begin{array}{l}\text { Stress relieving of } 102 \\
\text { primary tank started at 5:08 } \\
\text { pm. }\end{array}$ & Construction \\
\hline 273 & 5/24/1972 & Stress Relief & 102 & $\begin{array}{l}\text { As of } 8 \mathrm{pm} \text { all temperature } \\
\text { below } 600 \mathrm{~F} \text {, average reading } \\
\text { in kaolite was over } 250 \mathrm{~F} \text {. }\end{array}$ & \\
\hline 274 & 5/25/1972 & Stress Relief & 102 & $\begin{array}{l}\text { At } 3: 45 \text { pm max temp was } \\
600 \mathrm{~F} \text { and min temp was } \\
\text { 400F. }\end{array}$ & \\
\hline 275 & 5/25/1972 & Stress Relief & 102 & $\begin{array}{l}\text { At } 10: 10 \text { pm max temp was } \\
715 \mathrm{~F} \text { and min temp was } \\
520 \mathrm{~F} \text {. }\end{array}$ & \\
\hline 276 & 5/25/1972 & Stress Relief & 102 & $\begin{array}{l}\text { Lowest temp reached } 600 \mathrm{~F} \text { at } \\
\text { midnight. The began } \\
\text { increasing temps increased } \\
50-60 \mathrm{~F} \text { per hour. }\end{array}$ & \\
\hline 277 & $5 / 26 / 1972$ & Stress Relief & 102 & $\begin{array}{l}\text { Soak time started at } 9: 10 \text { am } \\
\text { when last TC reached } 1000 \mathrm{~F} \text {. } \\
\text { Max TC was } 1160 \mathrm{~F} \text {. Cooling } \\
\text { started at } 12: 10 \text { pm. TC \# } 12 \\
\text { considered erroneous. }\end{array}$ & Construction \\
\hline 278 & 5/30/1972 & Construction & 102 & $\begin{array}{l}\text { Examined } 102 \text { tank interior } \\
\text { and found post stress } \\
\text { condition normal and ready } \\
\text { for hydrostatic test. }\end{array}$ & \\
\hline 279 & $5 / 31 / 1972$ & Construction & 101 & $\begin{array}{l}\text { Work began on bellows and } \\
\text { penetrations on north south } \\
\text { centerline of } 101 \text { tank. }\end{array}$ & \\
\hline
\end{tabular}




\begin{tabular}{|c|c|c|c|c|c|}
\hline Reference & Date & $\log$ & Tank & Comments & Event \\
\hline 280 & 5/31/1972 & Construction & 102 & $\begin{array}{l}\text { Water being transfer from } \\
\text { TK } 101 \text { to TK } 102 \text {. }\end{array}$ & Construction \\
\hline 281 & 6/2/1972 & Construction & & $\begin{array}{l}\text { Pipe delivered for process fill } \\
\text { lines was not type 304L and } \\
\text { cannot be used. }\end{array}$ & \\
\hline 282 & 6/6/1972 & Construction & 101 & $\begin{array}{l}\text { Erection of truss system for } \\
\text { dome support during } \\
\text { concreting still in progress. }\end{array}$ & Construction \\
\hline 283 & 6/7/1972 & Construction & 102 & $\begin{array}{l}\text { Coating of the weld seams } \\
\text { with blue chalk for the } \\
\text { hydrostatic test was started. }\end{array}$ & \\
\hline 284 & 6/8/1972 & Construction & 102 & $\begin{array}{l}\text { Examined welds on the } 102 \\
\text { primary for leaks and found } \\
\text { none. }\end{array}$ & \\
\hline 285 & 6/8/1972 & Construction & 101 & $\begin{array}{l}\text { Air supply pipe being welded } \\
\text { into position on TK } 101 \\
\text { annulus. }\end{array}$ & \\
\hline 286 & 6/9/1972 & Construction & 102 & $\begin{array}{l}\text { Completed examination of } \\
102 \text { primary tank for leakage, } \\
\text { one minor repair was } \\
\text { required on penetration above } \\
\text { knuckle. Secondary haunch is } \\
\text { now being placed on } 102 \\
\text { tank. }\end{array}$ & Construction / Issue \\
\hline 287 & 6/12/1972 & Construction & 101 & $\begin{array}{l}\text { JAJ began placing re-stl on } \\
101 \text { tank for dome concrete. }\end{array}$ & \\
\hline 288 & 6/13/1972 & Construction & 102 & $\begin{array}{l}\text { Preparing to drain the } 102 \\
\text { primary tank. }\end{array}$ & \\
\hline 289 & 6/14/1972 & Construction & & $\begin{array}{l}\text { John Slaughter pickup up all } \\
\text { the AZ tank radiographs and } \\
\text { magnetic particle testing } \\
\text { reports, no further auditing } \\
\text { pending return of the } \\
\text { "books." }\end{array}$ & \\
\hline
\end{tabular}




\begin{tabular}{|c|c|c|c|c|c|}
\hline Reference & Date & Log & Tank & Comments & Event \\
\hline 290 & 6/22/1972 & Construction & & $\begin{array}{l}\text { Discovered that the welder } \\
\text { employed by Thompson } \\
\text { Mechanical on the fill lines } \\
\text { was not qualified on the } \\
\text { SMA process. One pass } \\
\text { remaining and weld } \\
\text { completed. PDM to } \\
\text { investigate prior qualification } \\
\text { and send weld to test ship for } \\
\text { immediate qualification. }\end{array}$ & Issue \\
\hline 291 & 6/23/1972 & Construction & & $\begin{array}{l}\text { Site visited by J. Slaughter } \\
\text { and J. Hendron and two } \\
\text { Westinghouse NDT } \\
\text { personnel. Visual inspection } \\
\text { and spot magnetic particle } \\
\text { testing conducted throughout } \\
\text { the day. }\end{array}$ & \\
\hline 292 & 6/26/1972 & Construction & & $\begin{array}{l}\text { Determined that welder had } \\
\text { prior qualification and } \\
\text { inspection showed welds are } \\
\text { acceptable, but that situation } \\
\text { should not re-occur. }\end{array}$ & Issue \\
\hline 293 & 6/27/1972 & Construction & & $\begin{array}{l}\text { Reinforced steel installation } \\
\text { taking place on both tanks }\end{array}$ & \\
\hline 294 & 7/5/1972 & Construction & 101 & $\begin{array}{l}\text { All items for dome pour on } \\
\text { TK } 101 \text { appear to be in order. }\end{array}$ & \\
\hline 295 & 7/6/1972 & Construction & 101 & $\begin{array}{l}\text { Dome pour to start at } 8: 20 \\
\text { am. Details logged by J. } \\
\text { Diehl, Vitro inspector on } \\
\text { concrete. Air introduced for } \\
\text { additional support, Vitro will } \\
\text { monitor internal pressure. }\end{array}$ & Construction \\
\hline 296 & 7/7/1972 & Construction & 101 & $\begin{array}{l}\text { Air pressure being } \\
\text { maintained while concrete is } \\
\text { curing. }\end{array}$ & \\
\hline 297 & 7/12/1972 & Construction & & $\begin{array}{l}\text { Strain gage installation and } \\
\text { re-stl work covered in log by } \\
\text { Nederhood and Diehl. }\end{array}$ & \\
\hline 298 & 7/13/1972 & Construction & 101 & Concrete pour today. & \\
\hline
\end{tabular}




\begin{tabular}{|c|c|c|c|c|c|}
\hline Reference & Date & Log & Tank & Comments & Event \\
\hline 299 & 7/17/1972 & Construction & 101 & $\begin{array}{l}\text { Truss can be removed if a 1) } \\
\text { air pressure maintained, 2) } \\
\text { cylinder test shows } 2000 \text { psi } \\
\text { minimum after } 3 \text { days (test } \\
\text { on } 2 \text { cylinders were } 2100+ \\
\text { and } 2300^{+} \text {). }\end{array}$ & Construction \\
\hline 300 & 7/24/1972 & Construction & 101 & $\begin{array}{l}\text { Entry into tank } 101 \text { today to } \\
\text { check unwelded gouge in E-1 } \\
\text { seam and "pitting" detected } \\
\text { in recent audit. Many } \\
\text { dimensions taken to aid in } \\
\text { disposition. }\end{array}$ & Issue \\
\hline 301 & 7/25/1972 & Construction & 101 & $\begin{array}{l}\text { Visited tank } 101 \text { for } \\
\text { additional data. }\end{array}$ & \\
\hline 302 & 7/28/1972 & Construction & 101 & $\begin{array}{l}\text { Preformed dye penetrant } \\
\text { examination of the gouge in } \\
\text { E-1 seam, tank } 101 \text {. No } \\
\text { rejectable discontinuities } \\
\text { found. }\end{array}$ & Issue \\
\hline 303 & 7/31/1972 & Construction & 102 & Haunch Pour today. & Construction \\
\hline 304 & 8/4/1972 & Construction & 102 & $\begin{array}{l}\text { Dome pour today, air } \\
\text { pressure being maintained. }\end{array}$ & \\
\hline 305 & 8/8/1972 & Construction & 102 & $\begin{array}{l}\text { Two test cylinders broken } \\
\text { today, results were } 2100+\text {, } \\
\text { truss can be removed. }\end{array}$ & Construction \\
\hline 306 & 8/11/1972 & Construction & & $\begin{array}{l}\text { Due other commitments } \\
\text { removed from AZ farm, for } \\
\text { progress and daily coverage } \\
\text { refer to log of J. Parrish. }\end{array}$ & \\
\hline 307 & 8/21/1972 & Construction & & $\begin{array}{l}\text { Thru 9/5/71, Backfilling AZ } \\
\text { excavation. }\end{array}$ & Construction \\
\hline 308 & 9/6/1972 & Construction & & $\begin{array}{l}\text { Official acceptance of } \\
\text { construction inspection today } \\
\text { by J.Slaughter (AEC), J. } \\
\text { Kemp (ARHCO for W.C. } \\
\text { Armstrong), and this author. } \\
\text { Accepted with two minor } \\
\text { exceptions. }\end{array}$ & Construction \\
\hline
\end{tabular}


RPP-RPT-54818, Rev. 0

\begin{tabular}{|c|c|c|c|c|}
\hline Reference & Date & \multicolumn{1}{|c|}{ Log } & Tank & \multicolumn{1}{|c|}{ Comments } \\
\hline $\mathbf{3 0 9}$ & $9 / 6 / 1972$ & Construction & $\begin{array}{l}\text { Event } \\
\text { Repeated request to JAJ that } \\
\text { information necessary } \\
\text { (material certs, welder } \\
\text { qualification, and weld } \\
\text { procedures) regard Phase III } \\
\text { work was not submitted. }\end{array}$ \\
\hline $\mathbf{3 1 0}$ & $9 / 7 / 1972$ & Construction & $\begin{array}{l}\text { Initiated NCR-V-NC-4 for } \\
\text { lack of submittals mentioned } \\
\text { in 9/6. }\end{array}$ \\
\hline $\mathbf{3 1 1}$ & $10 / 2 / 1972$ & Construction & $\begin{array}{l}\text { AZ farm work shutdown by } \\
\text { JAJ, lack of approved } \\
\text { specifications. }\end{array}$ \\
\hline $\mathbf{3 1 2}$ & $10 / 6 / 1972$ & Construction & $\begin{array}{l}\text { Last entry says work still on } \\
\text { hold, expected to resume next } \\
\text { week. }\end{array}$ \\
\hline
\end{tabular}


RPP-RPT-54818, Rev. 0

APPENDIX B 241-AZ Tank Farm Weld Maps

\begin{tabular}{lc}
\hline \multicolumn{1}{c}{ Figure } & Page \\
\hline App Figure B-1. Tank AZ-101 Secondary Bottom Weld Map & B-2 \\
\hline App Figure B-2. Tank AZ-102 Secondary Bottom Weld Map & B-3 \\
\hline App Figure B-3. Tank AZ-101 Secondary Shell Weld Map (1 of 4) & B-4 \\
\hline App Figure B-4. Tank AZ-101 Secondary Shell Weld Map (2 of 4) & B-4 \\
\hline App Figure B-5. Tank AZ-101 Secondary Shell Weld Map (3 of 4) & B-5 \\
\hline App Figure B-6. Tank AZ-101 Secondary Shell Weld Map (4 of 4) & B-5 \\
\hline App Figure B-7. Tank AZ-102 Secondary Shell Weld Map (1 of 4) & B-6 \\
\hline App Figure B-8. Tank AZ-102 Secondary Shell Weld Map (2 of 4) & B-6 \\
\hline App Figure B-9. Tank AZ-102 Secondary Shell Weld Map (3 of 4) & B-7 \\
\hline App Figure B-10. Tank AZ-102 Secondary Shell Weld Map (4 of 4) & B-7 \\
\hline App Figure B-11. Tank AZ-101 Primary Bottom Weld Map & B-8 \\
\hline App Figure B-12. Tank AZ-102 Primary Bottom Weld Map & B-9 \\
\hline App Figure B-13. Tank AZ-101 Primary Shell Weld Map (1 of 4) & B-10 \\
\hline App Figure B-14. Tank AZ-101 Primary Shell Weld Map (2 of 4) & B-10 \\
\hline App Figure B-15. Tank AZ-101 Primary Shell Weld Map (3 of 4) & B-11 \\
\hline App Figure B-16. Tank AZ-101 Primary Shell Weld Map (4 of 4) & B-11 \\
\hline App Figure B-17. Tank AZ-102 Primary Shell Weld Map (1 of 4) & B-12 \\
\hline App Figure B-18. Tank AZ-102 Primary Shell Weld Map (2 of 4) & B-12 \\
\hline App Figure B-19. Tank AZ-102 Primary Shell Weld Map (3 of 4) & B-13 \\
\hline App Figure B-20. Tank AZ-102 Primary Shell Weld Map (4 of 4) & B-13 \\
\hline
\end{tabular}


RPP-RPT-54818, Rev. 0

\section{App Figure B-1. Tank AZ-101 Secondary Bottom Weld Map}

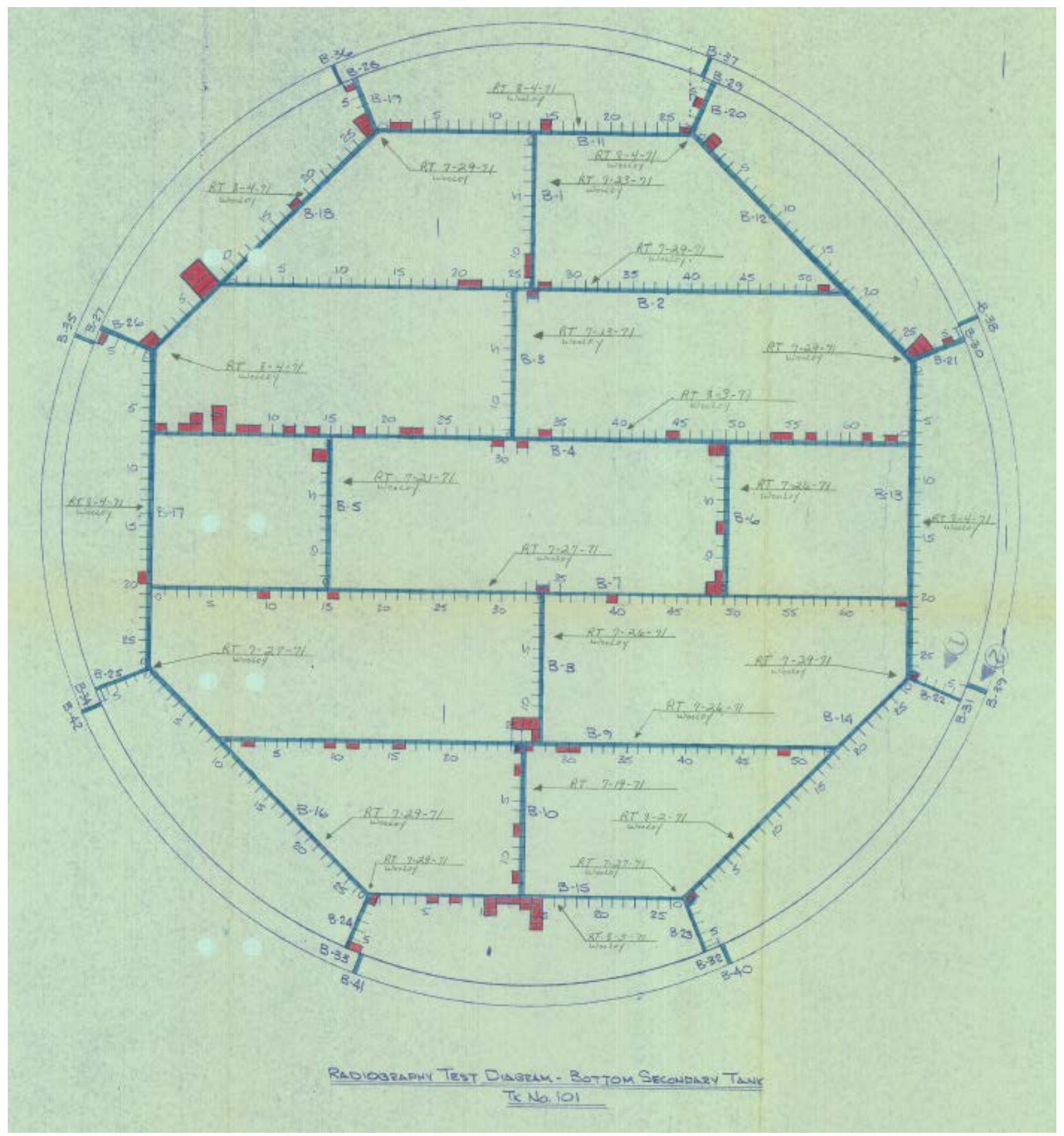


RPP-RPT-54818, Rev. 0

App Figure B-2. Tank AZ-102 Secondary Bottom Weld Map

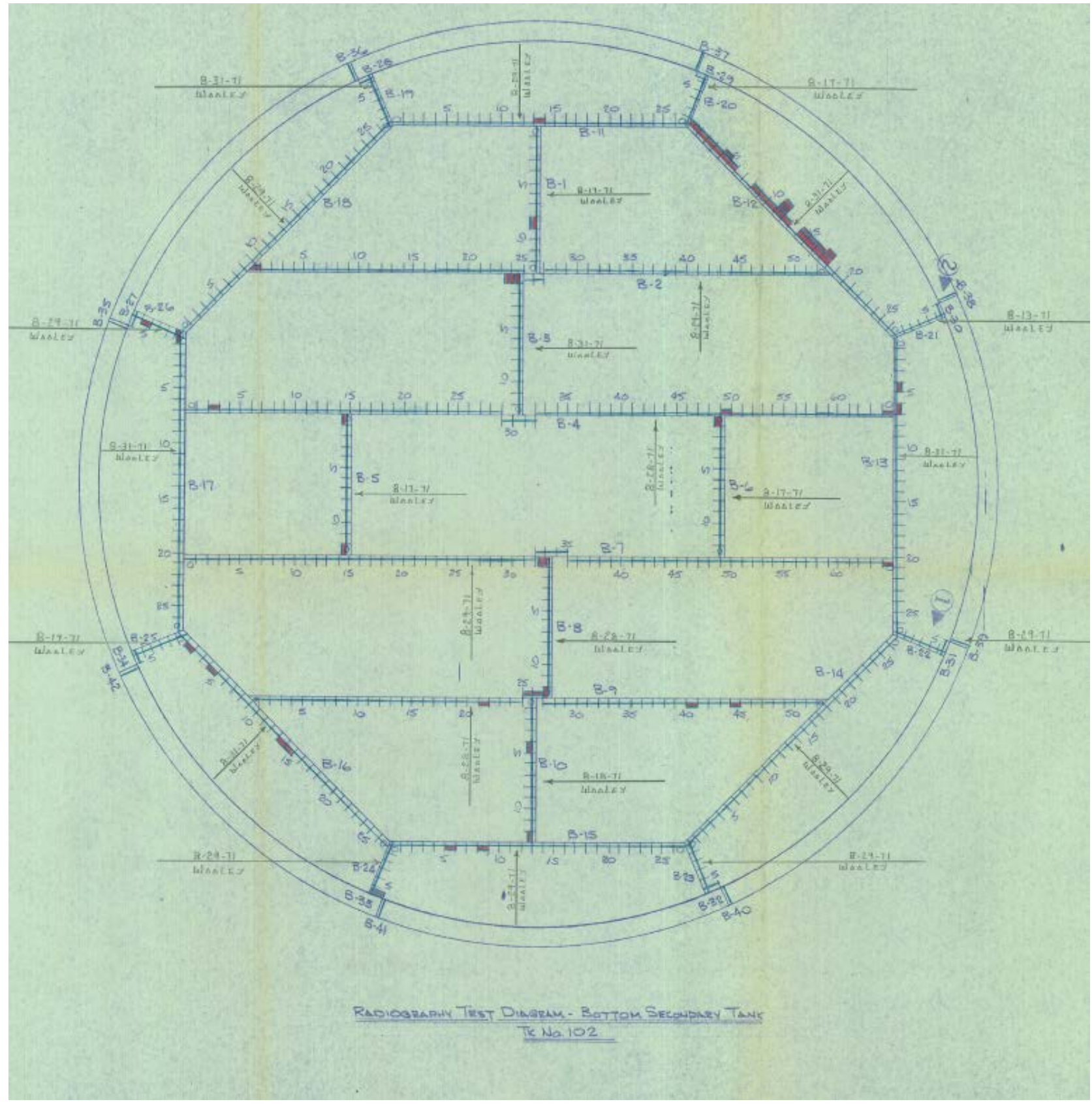


RPP-RPT-54818, Rev. 0

App Figure B-3. Tank AZ-101 Secondary Shell Weld Map (1 of 4)

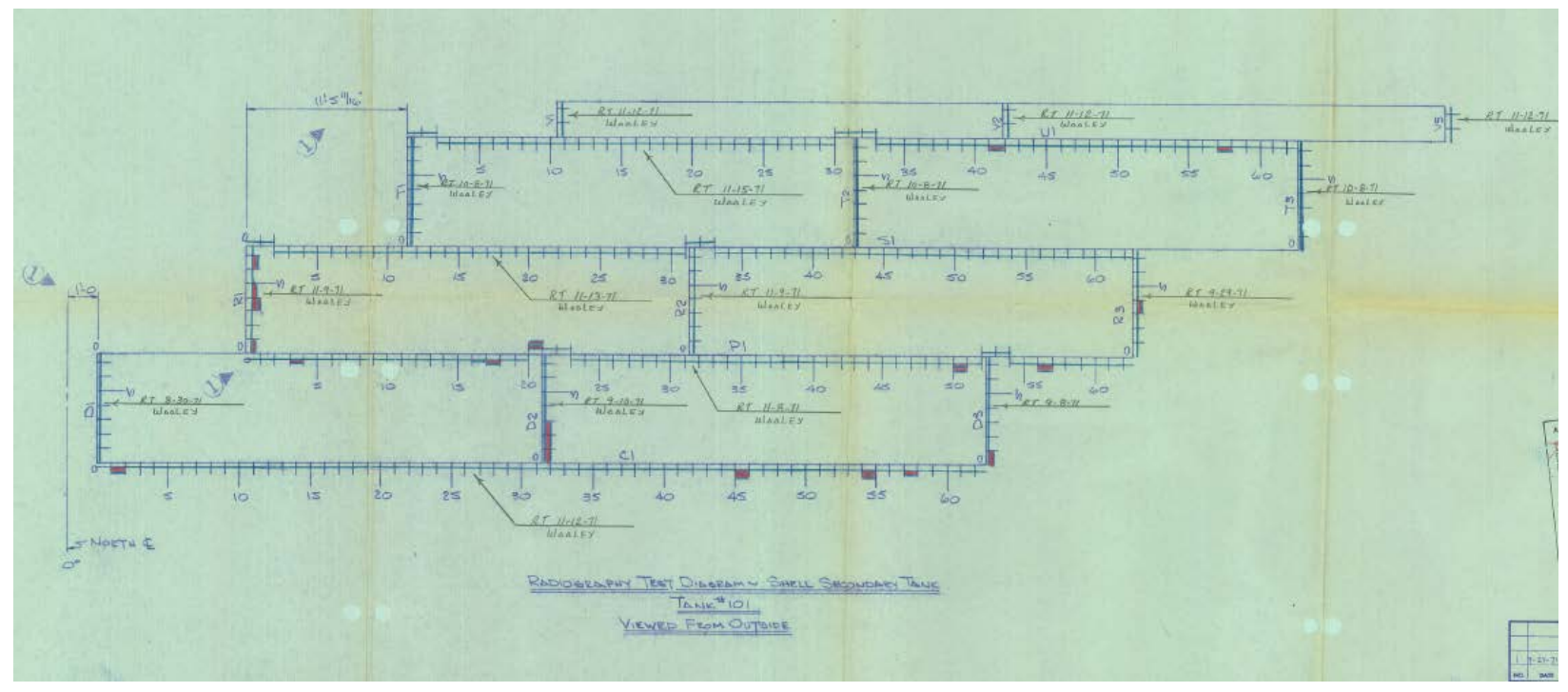

App Figure B-4. Tank AZ-101 Secondary Shell Weld Map (2 of 4)

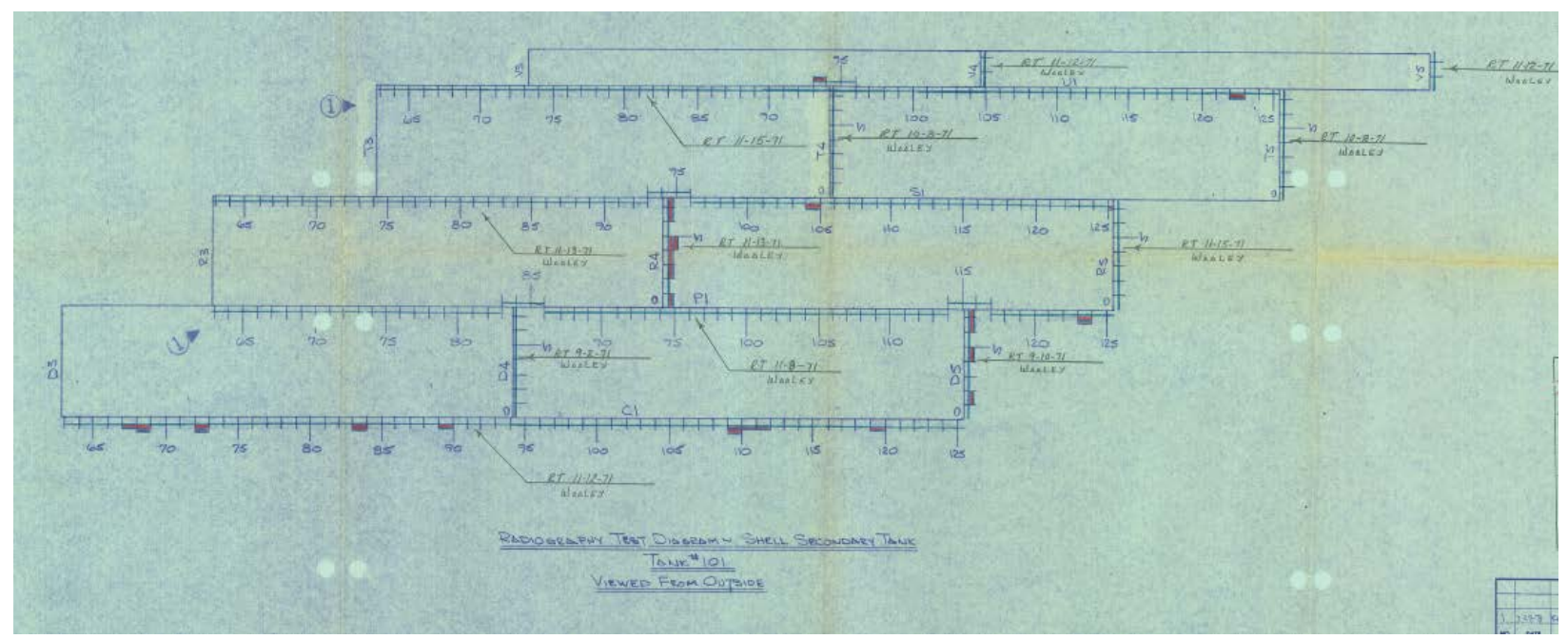


RPP-RPT-54818, Rev. 0

App Figure B-5. Tank AZ-101 Secondary Shell Weld Map (3 of 4)

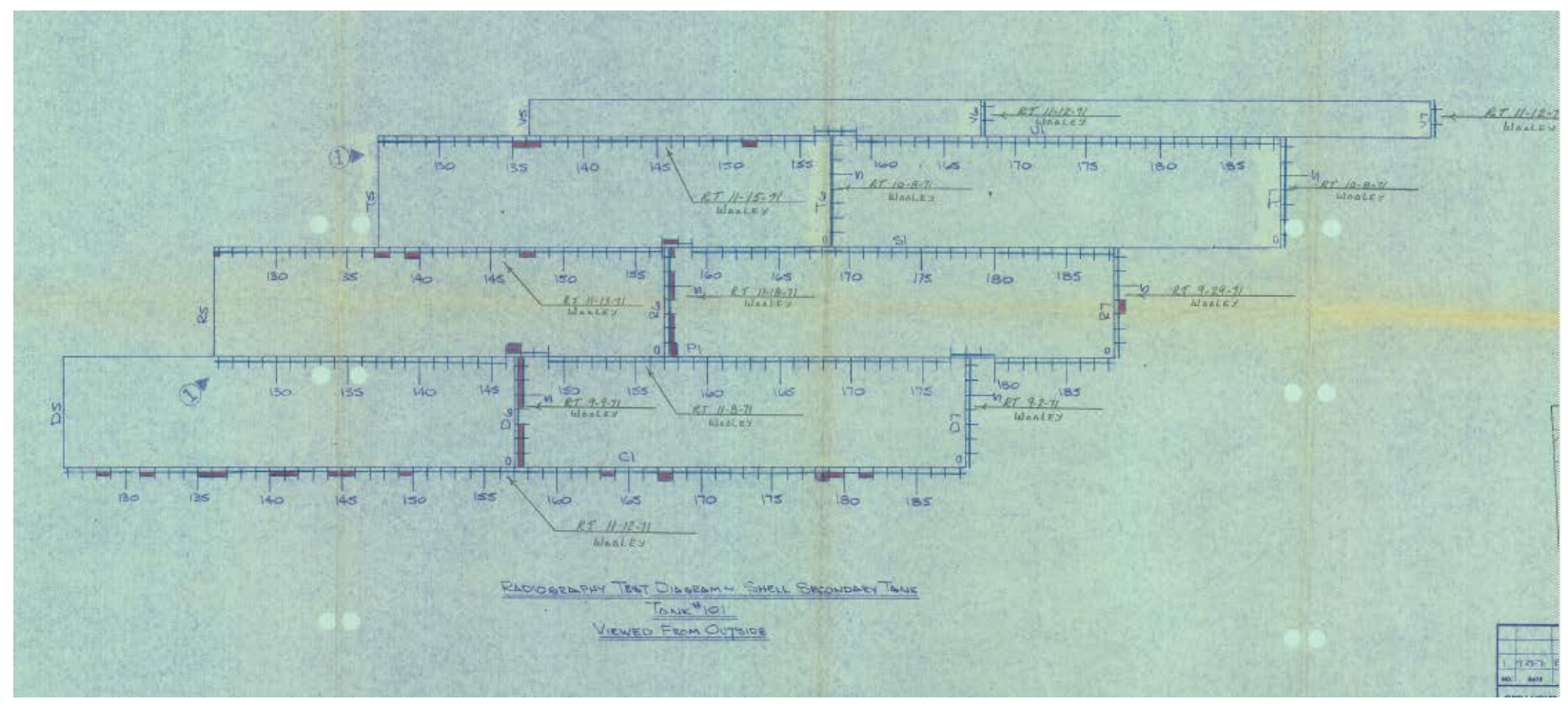

App Figure B-6. Tank AZ-101 Secondary Shell Weld Map (4 of 4)

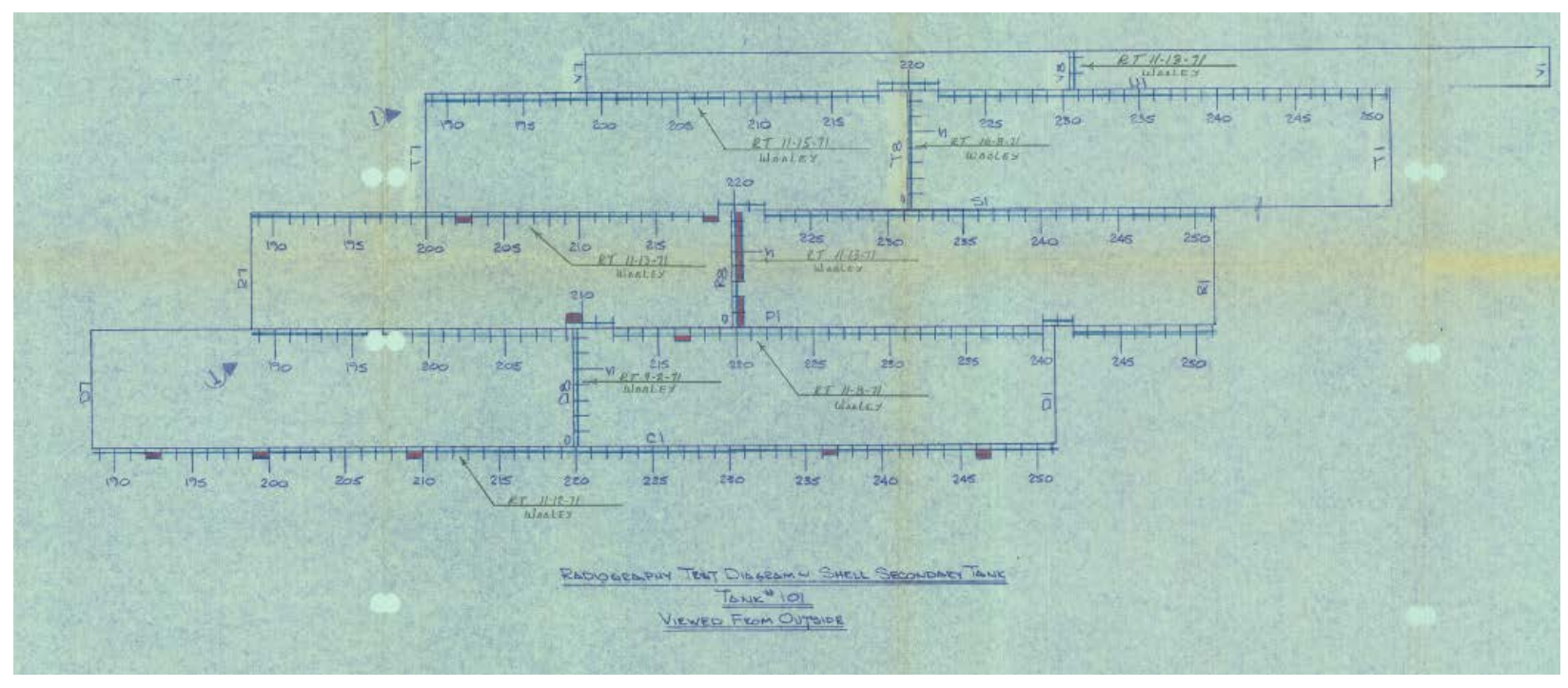


RPP-RPT-54818, Rev. 0

\section{App Figure B-7. Tank AZ-102 Secondary Shell Weld Map (1 of 4)}

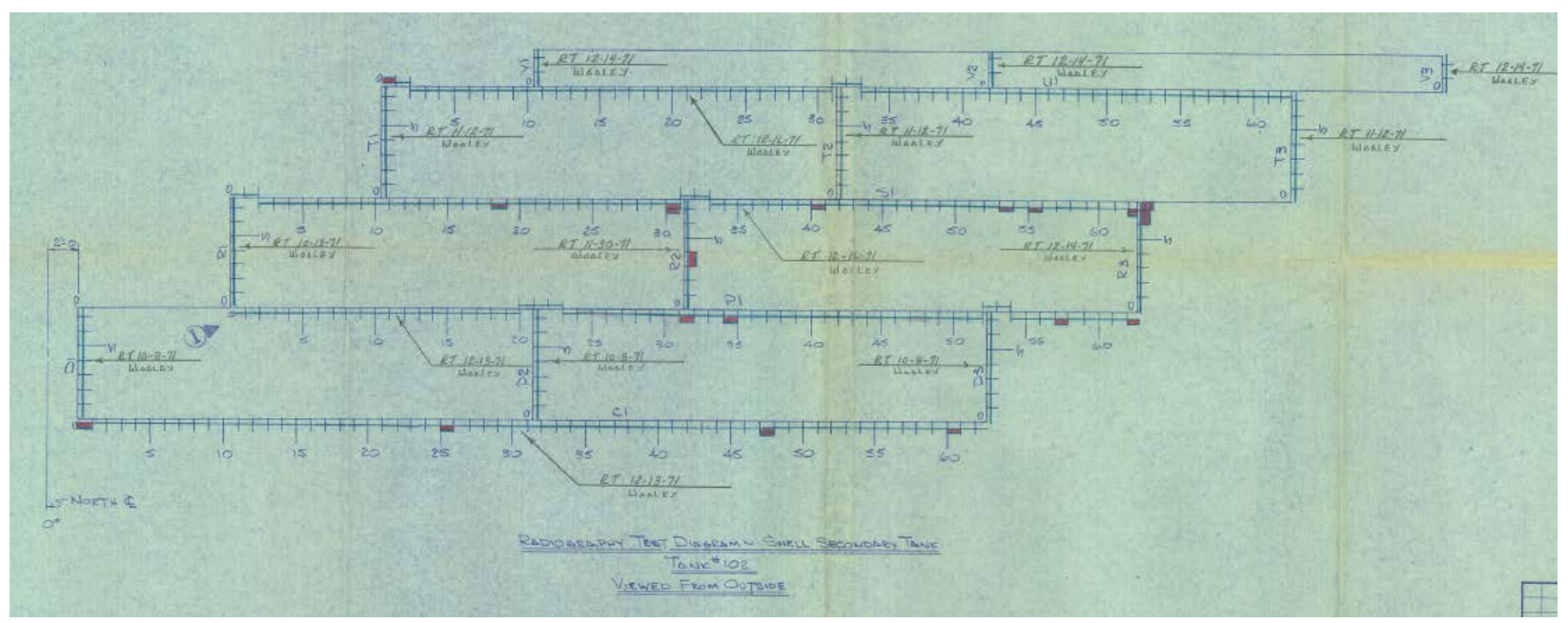

App Figure B-8. Tank AZ-102 Secondary Shell Weld Map (2 of 4)

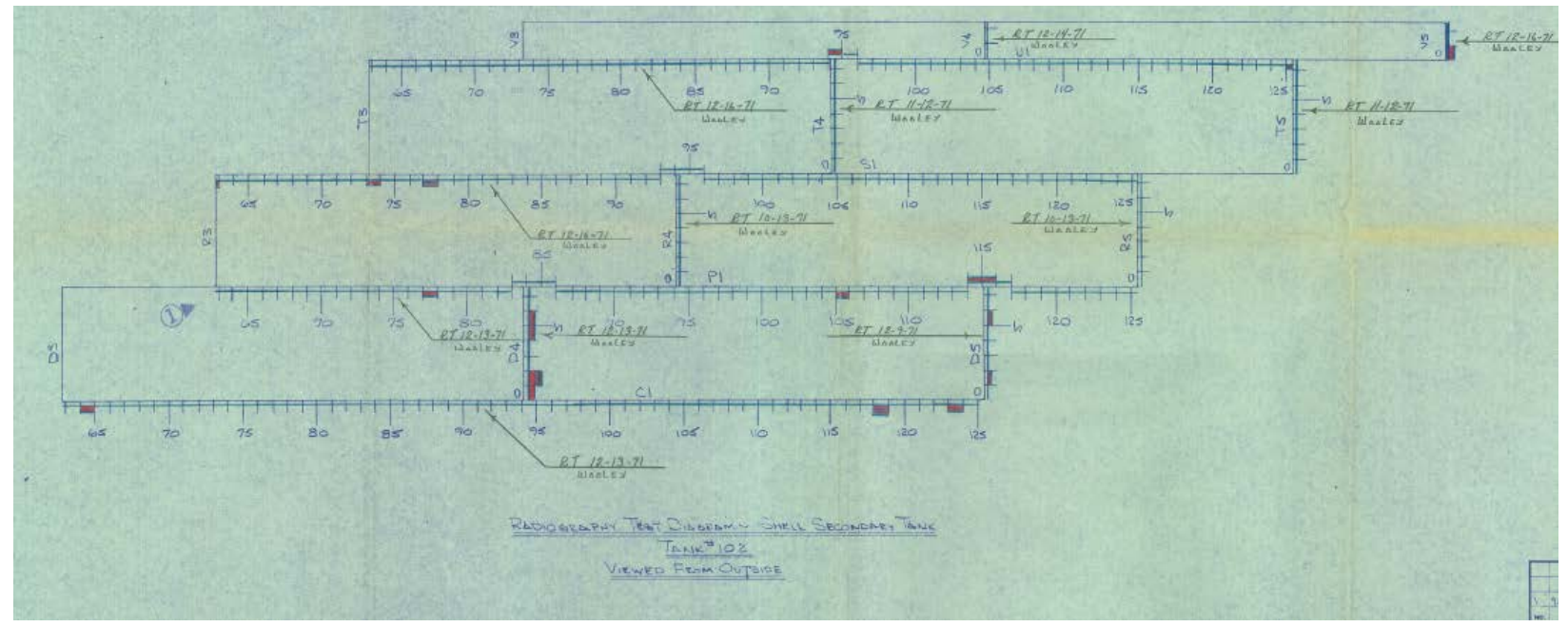


RPP-RPT-54818, Rev. 0

\section{App Figure B-9. Tank AZ-102 Secondary Shell Weld Map (3 of 4)}

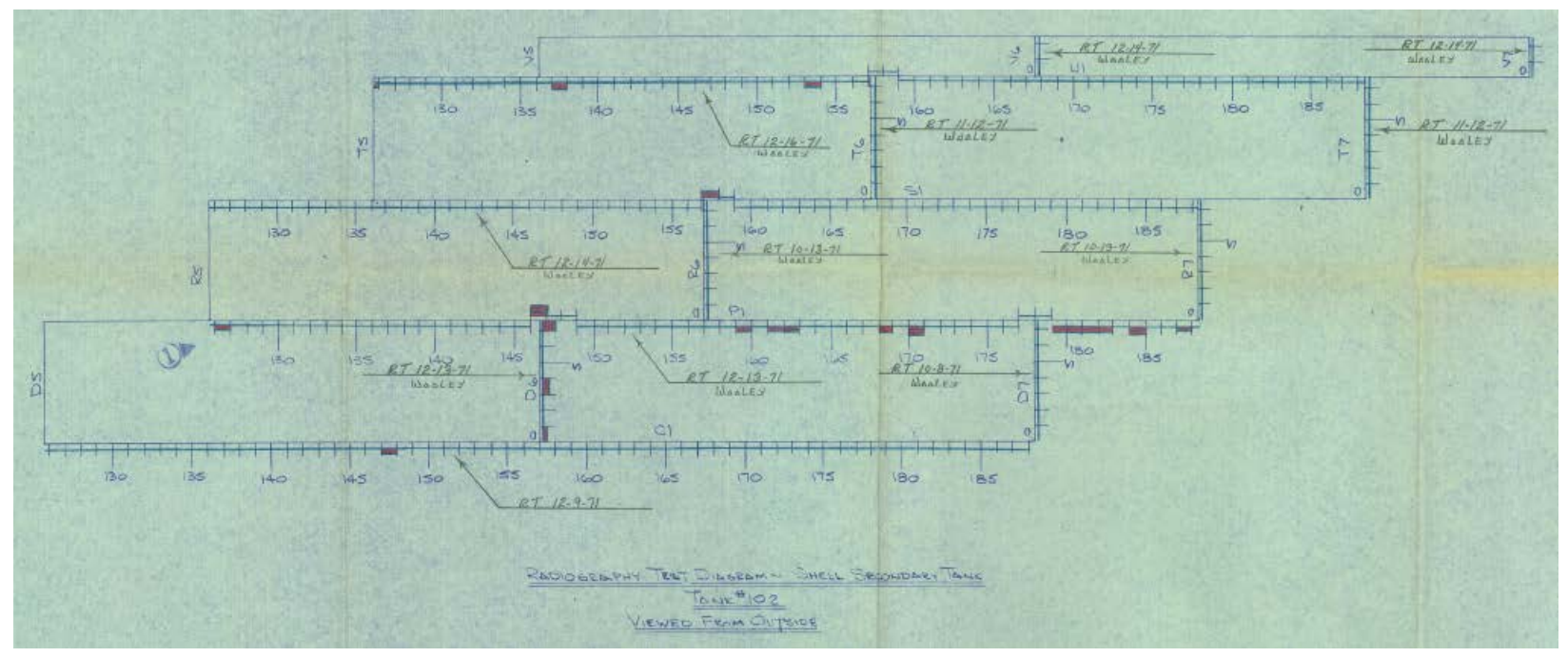

App Figure B-10. Tank AZ-102 Secondary Shell Weld Map (4 of 4)

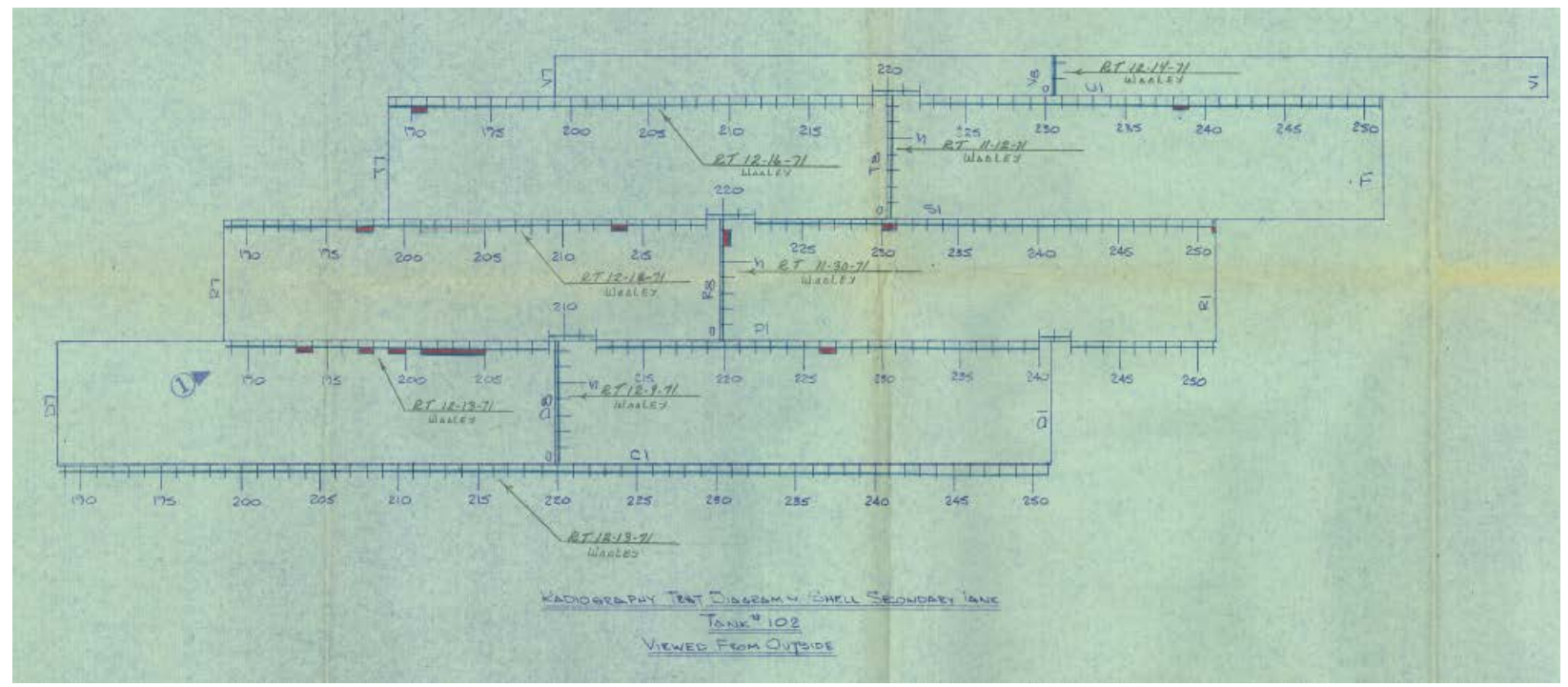


RPP-RPT-54818, Rev. 0

App Figure B-11. Tank AZ-101 Primary Bottom Weld Map

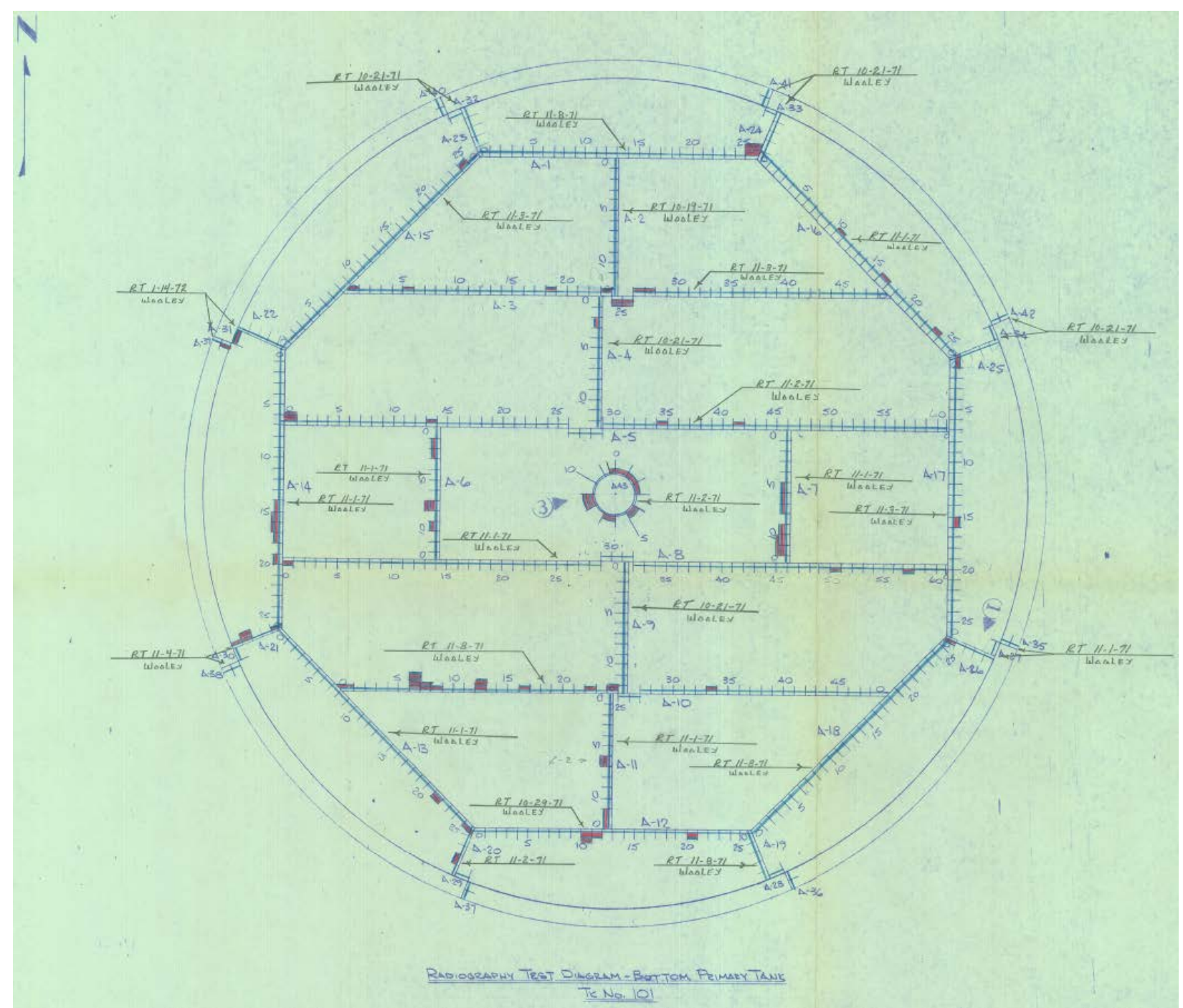


RPP-RPT-54818, Rev. 0

App Figure B-12. Tank AZ-102 Primary Bottom Weld Map

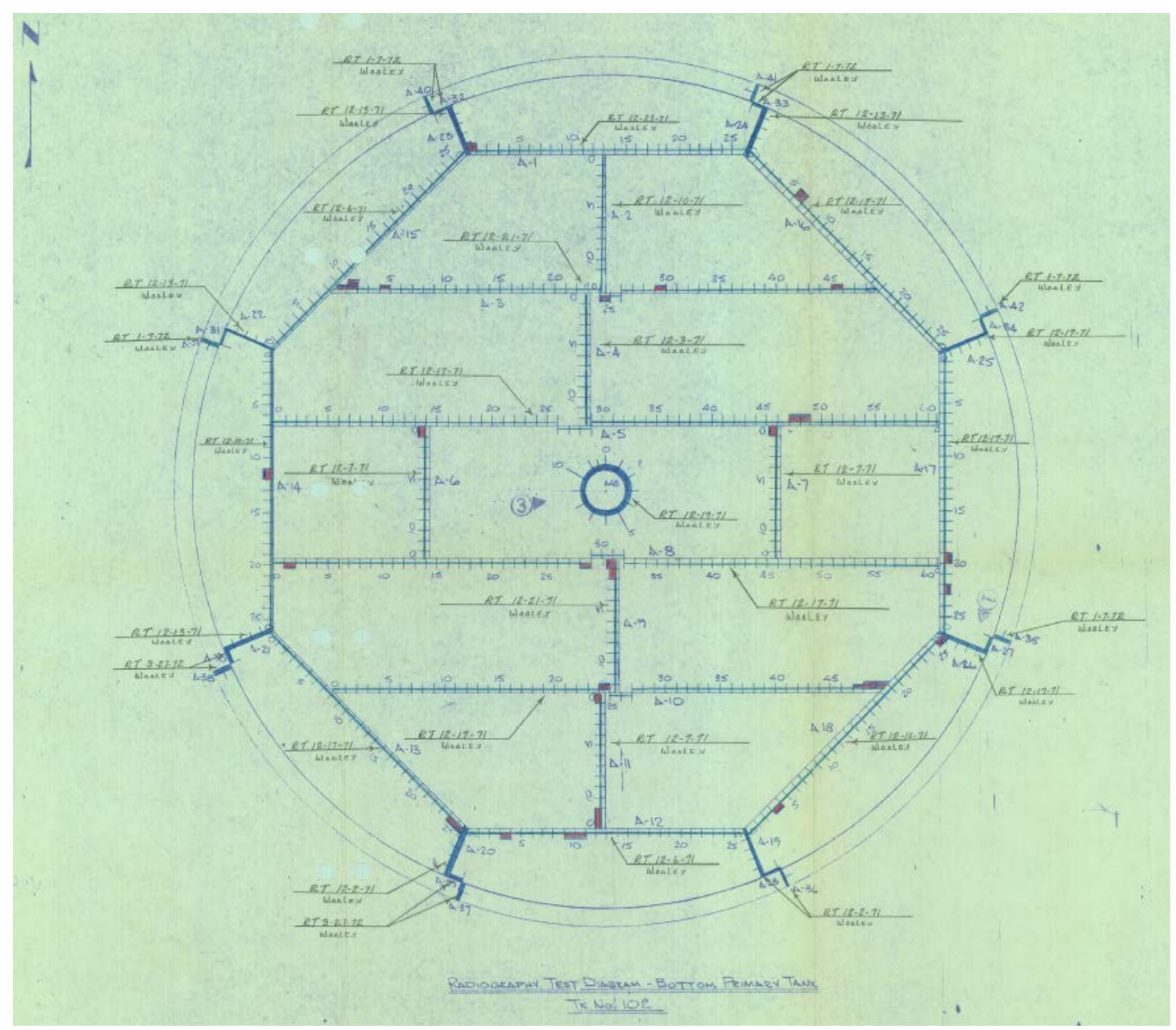


RPP-RPT-54818, Rev. 0

App Figure B-13. Tank AZ-101 Primary Shell Weld Map (1 of 4)

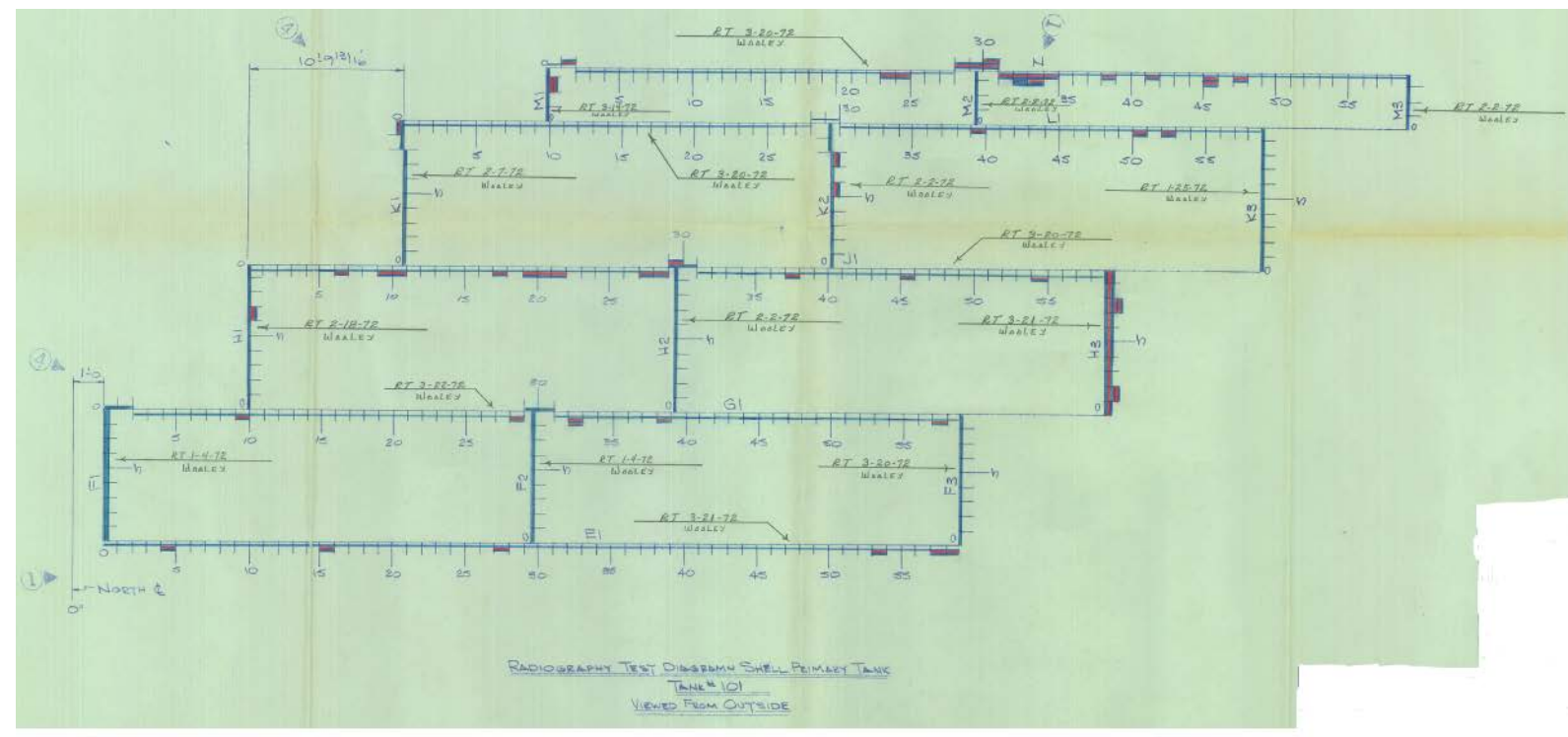

App Figure B-14. Tank AZ-101 Primary Shell Weld Map (2 of 4)

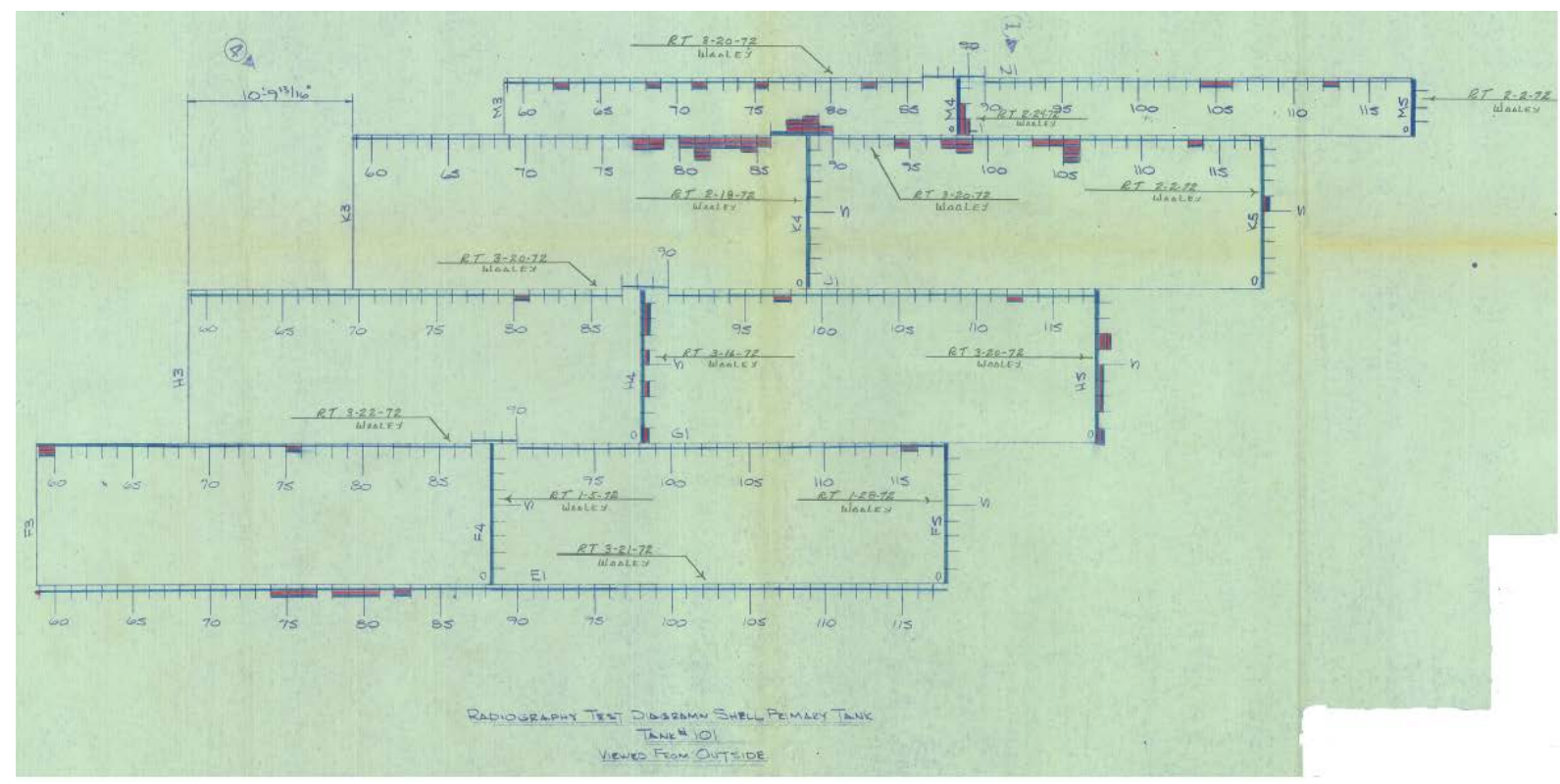


RPP-RPT-54818, Rev. 0

App Figure B-15. Tank AZ-101 Primary Shell Weld Map (3 of 4)

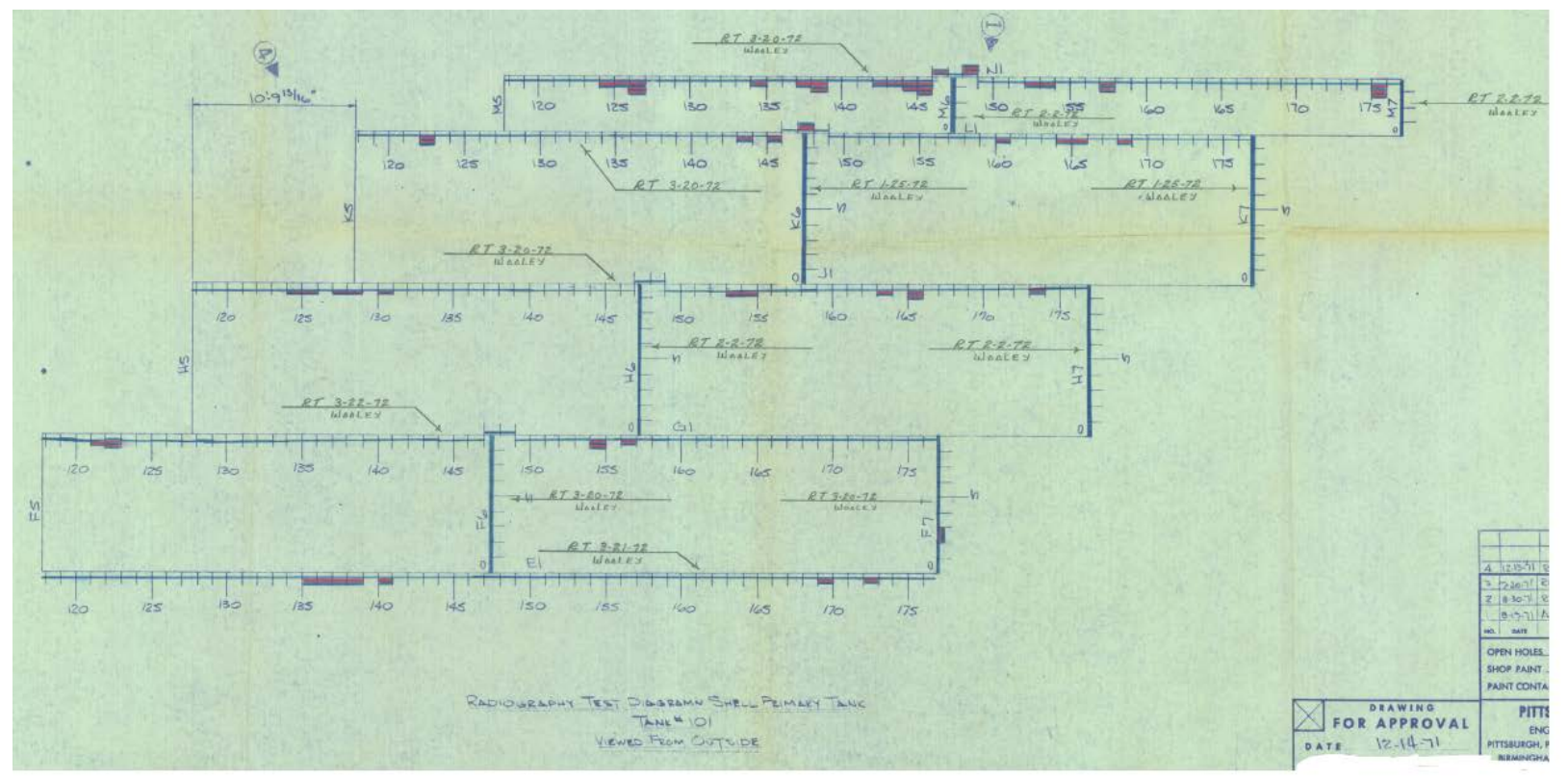

App Figure B-16. Tank AZ-101 Primary Shell Weld Map (4 of 4)

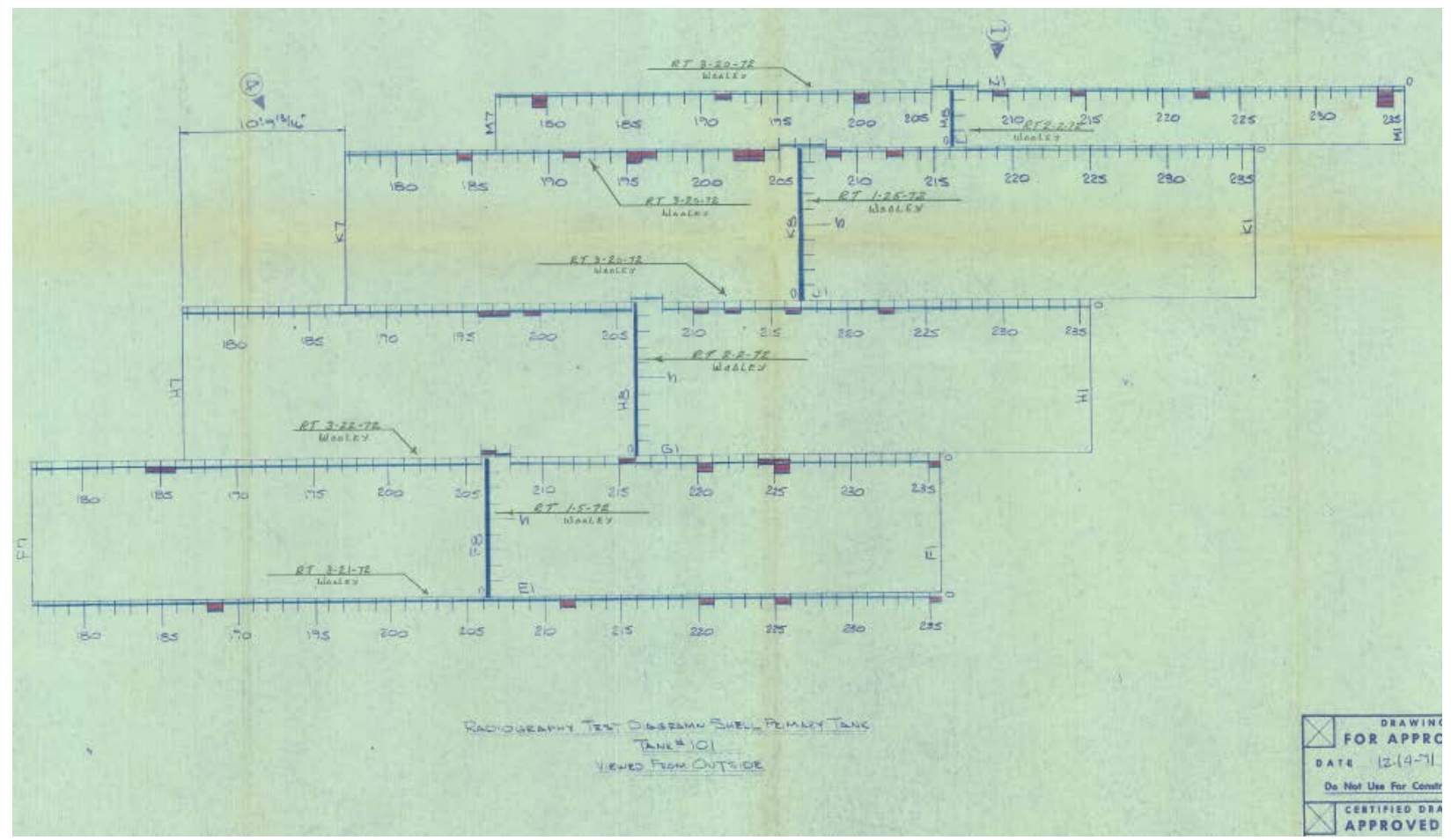


RPP-RPT-54818, Rev. 0

\section{App Figure B-17. Tank AZ-102 Primary Shell Weld Map (1 of 4)}

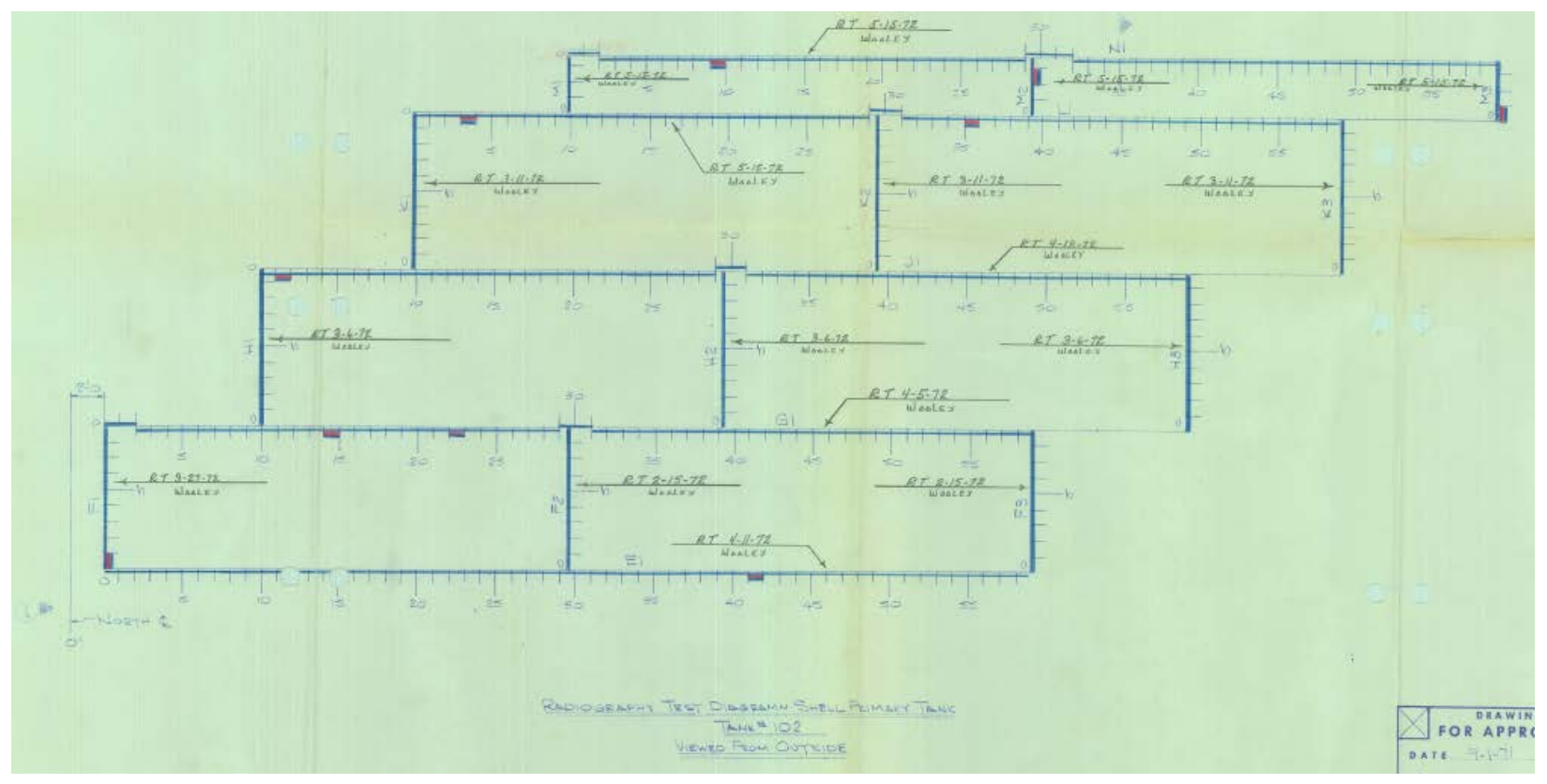

App Figure B-18. Tank AZ-102 Primary Shell Weld Map (2 of 4)

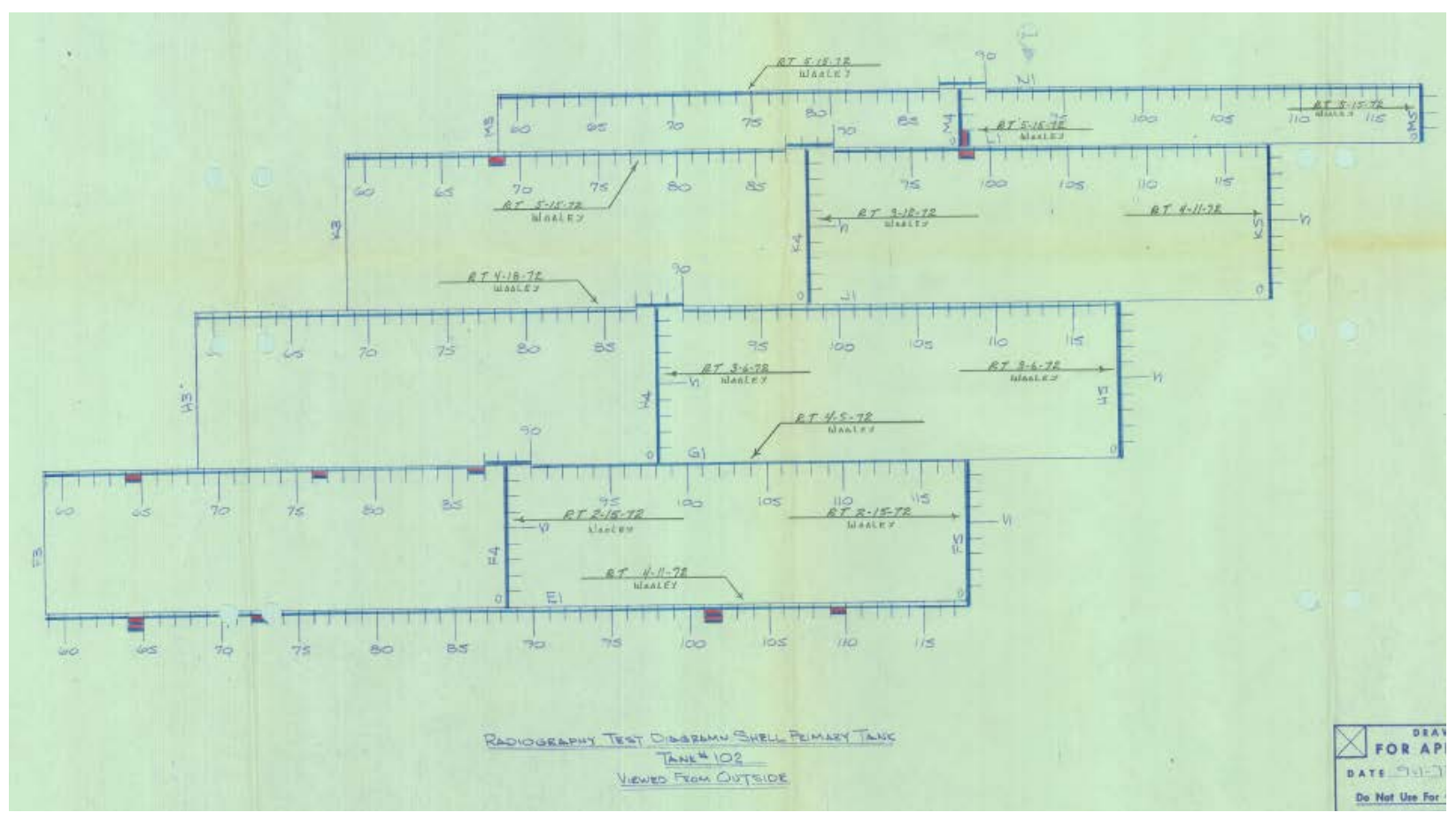


RPP-RPT-54818, Rev. 0

\section{App Figure B-19. Tank AZ-102 Primary Shell Weld Map (3 of 4)}

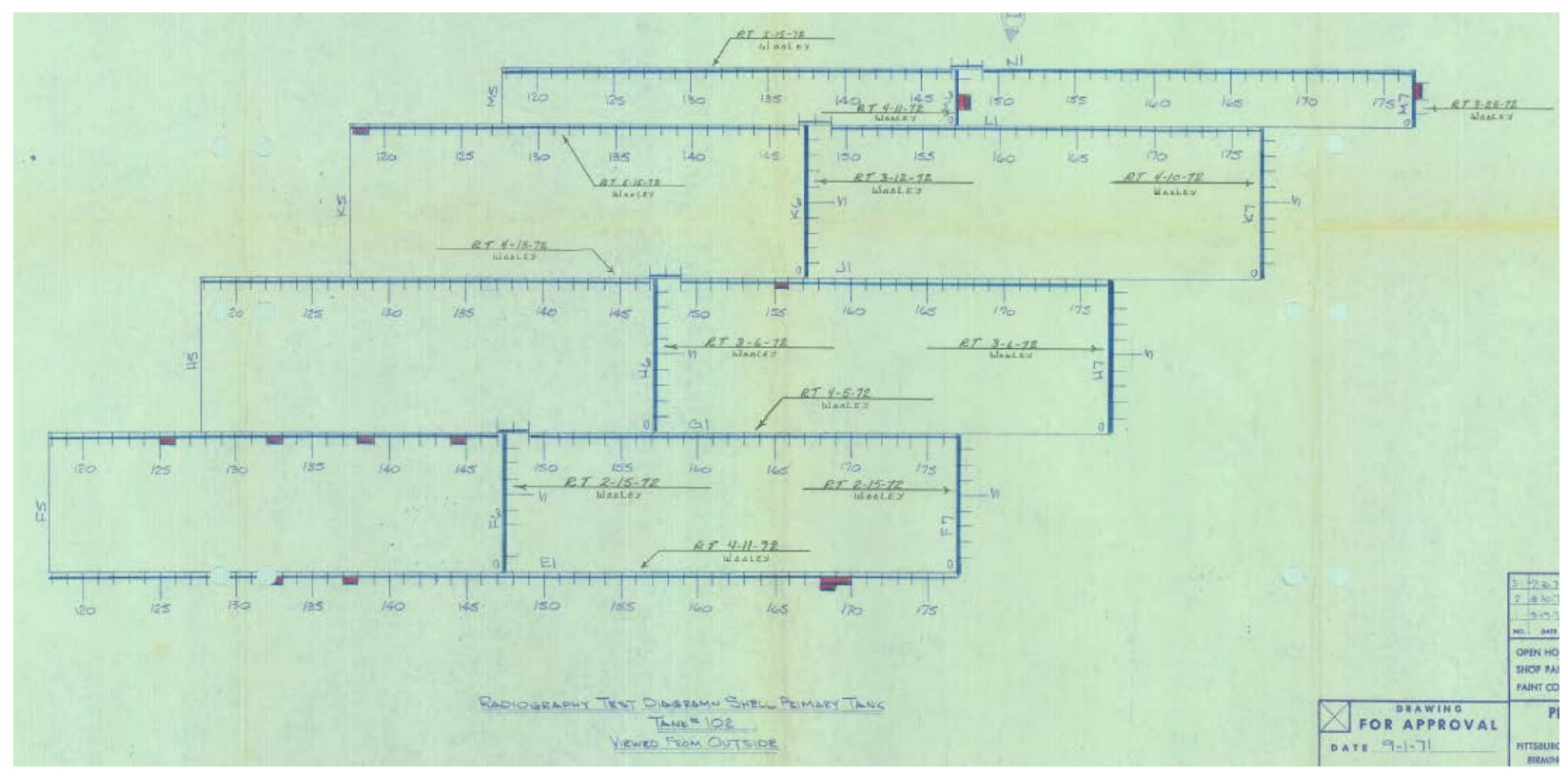

App Figure B-20. Tank AZ-102 Primary Shell Weld Map (4 of 4)

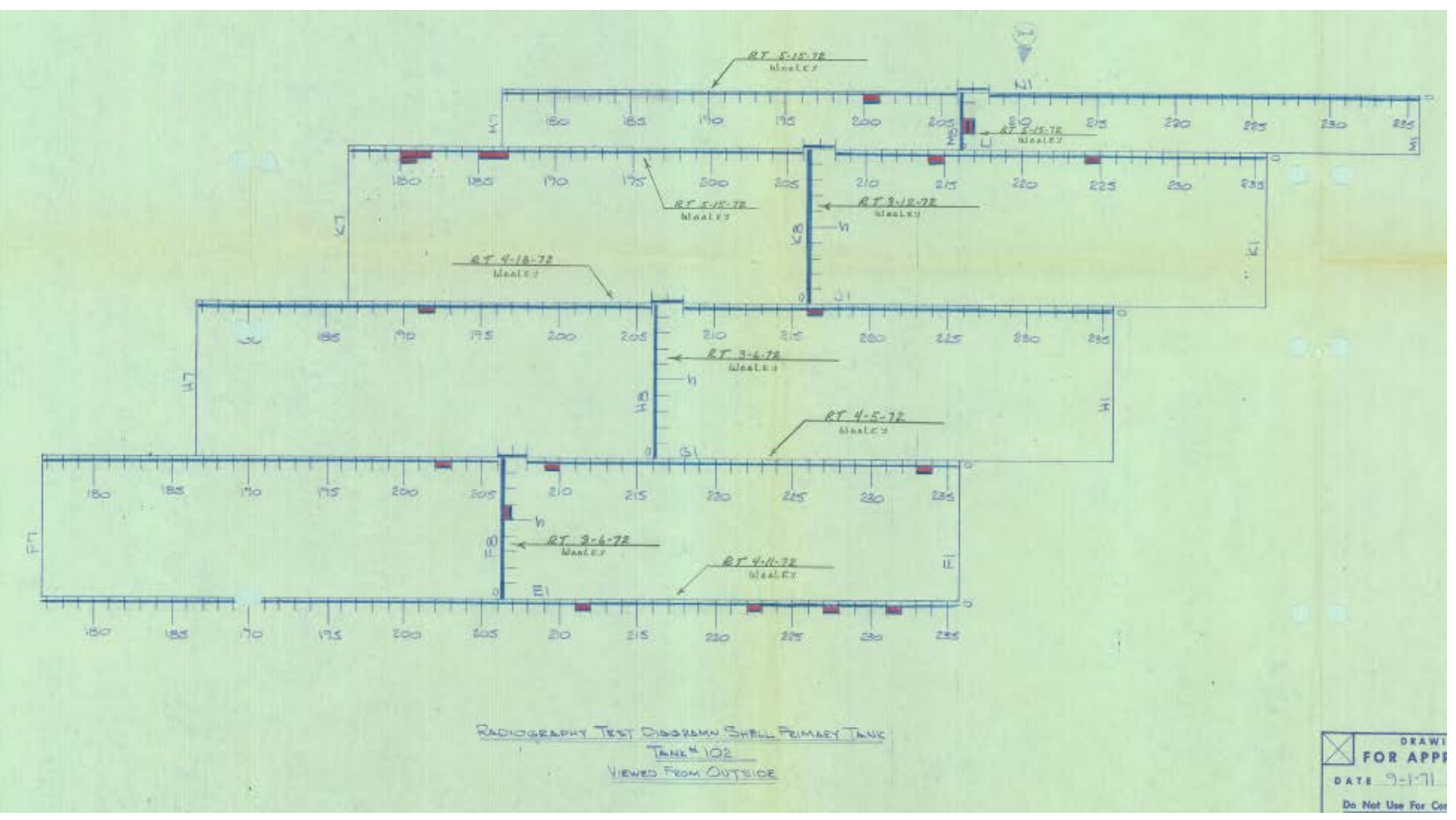


RPP-RPT-54818, Rev. 0

\section{APPENDIX C Tank Deficiency Documentation}

\begin{tabular}{|c|c|}
\hline Figure & Page \\
\hline $\begin{array}{l}\text { App Figure C-1. Plate Laminations Nondestructive Test Report 72-41 (Dated 3/17/72) } \\
\text { (2 Pages) }\end{array}$ & C-2 \\
\hline $\begin{array}{l}\text { App Figure C-2. Plate Laminations Nondestructive Test Report 72-41-1 (Dated 3/27/72) } \\
\text { (3 Pages) }\end{array}$ & $\mathrm{C}-4$ \\
\hline App Figure C-3. Plate Laminations Deficiency or Variation Report (Dated 4/27/72) & C-7 \\
\hline $\begin{array}{l}\text { App Figure C-4. Weld Seam E-1 Grind Out Deficiency or Variation Report (Dated } \\
\text { 8/25/72) }\end{array}$ & C-8 \\
\hline $\begin{array}{l}\text { App Figure C-5. Letter from J.H. Slaughter to J.M. Frame Regarding Audit Findings } \\
\text { (Dated 7/13/72) }\end{array}$ & C-9 \\
\hline $\begin{array}{l}\text { App Figure C-6. Letter from E.F. Smith to J.H. Slaughter Regarding Audit Findings } \\
\text { (Dated 7/28/72) (2 Pages) }\end{array}$ & C-10 \\
\hline $\begin{array}{l}\text { App Figure C-7. Letter from W.C. Armstrong to J.H Slaughter Regarding Weld Seam E- } \\
1 \text { Grind Out (Dated 8/24/72) }\end{array}$ & C-12 \\
\hline $\begin{array}{l}\text { App Figure C-8. Letter from E.L Moore to W.C. Armstrong Regarding Pitting (Dated } \\
\text { 8/7/72) (2 pages) }\end{array}$ & C-13 \\
\hline App Figure C-9. Refractory Thickness Deficiency or Variation Report (Dated 8/23/71) & C-15 \\
\hline $\begin{array}{l}\text { App Figure C-10. Refractory Retaining Band Installed Upside Down Deficiency or } \\
\text { Variation Report (Dated 10/6/71) }\end{array}$ & C-16 \\
\hline $\begin{array}{l}\text { App Figure C-11. Retaining Band Slots and Drainage Holes Deficiency or Variation } \\
\text { Report (Dated 11/12/71) (2 Pages) }\end{array}$ & C-17 \\
\hline $\begin{array}{l}\text { App Figure C-12. Refractory Guidance by Babcock and Wilcox (Dated 6/4/71) (4 } \\
\text { Pages) }\end{array}$ & C-19 \\
\hline App Figure C-13. Protection of Kaolite - Action Taken (Dated 12/16/71) & C-23 \\
\hline App Figure C-14. Explanation of Frost Discovery and Actions Taken (Dated 12/20/1) & $\mathrm{C}-24$ \\
\hline $\begin{array}{l}\text { App Figure C-15. Application of Auxiliary Heat to Tanks AZ-101 and AZ-102 (Dated } \\
\text { 12/20/71) }\end{array}$ & $\mathrm{C}-25$ \\
\hline App Figure C-16. Stress Relieving Deficiency or Variation Report (Dated 5/4/72) & $\mathrm{C}-26$ \\
\hline $\begin{array}{l}\text { App Figure C-17. Radiography Misrepresentation Memorandum (Dated 8/6/71) (2 } \\
\text { Pages) }\end{array}$ & $\mathrm{C}-27$ \\
\hline $\begin{array}{l}\text { App Figure C-18. AZ } 102 \text { Knuckle Plates Deficiency or Variation Report (Dated } \\
\text { 10/15/71) (2 Pages) }\end{array}$ & C-29 \\
\hline $\begin{array}{l}\text { App Figure C-19. AZ } 101 \text { Knuckle Plates Deficiency or Variation Report (Dated } \\
\text { 11/2/71) (2 Pages) }\end{array}$ & C-31 \\
\hline
\end{tabular}


App Figure C-1. Plate Laminations Nondestructive Test Report 72-41 (Dated 3/17/72) (2 Pages)

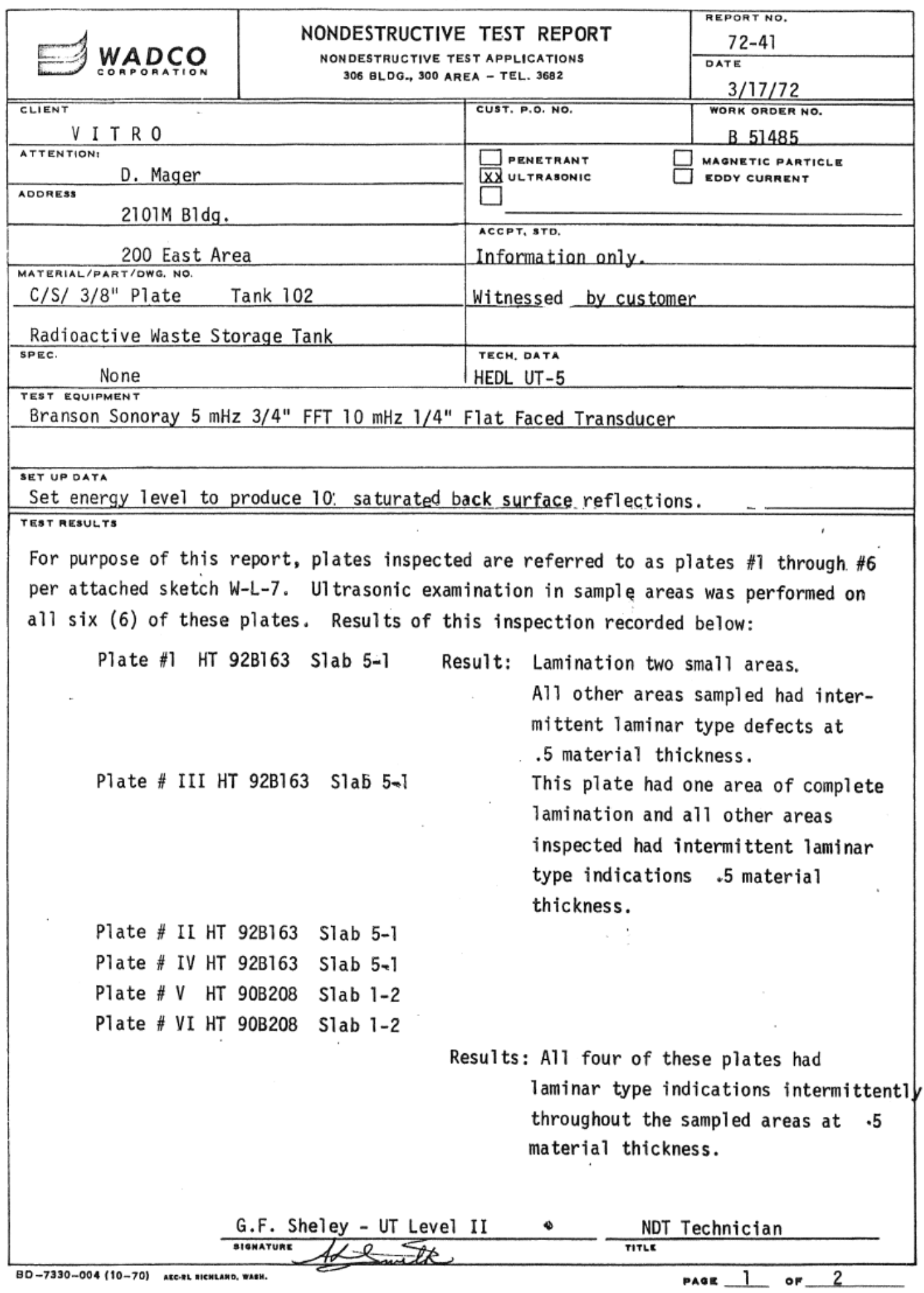


RPP-RPT-54818, Rev. 0

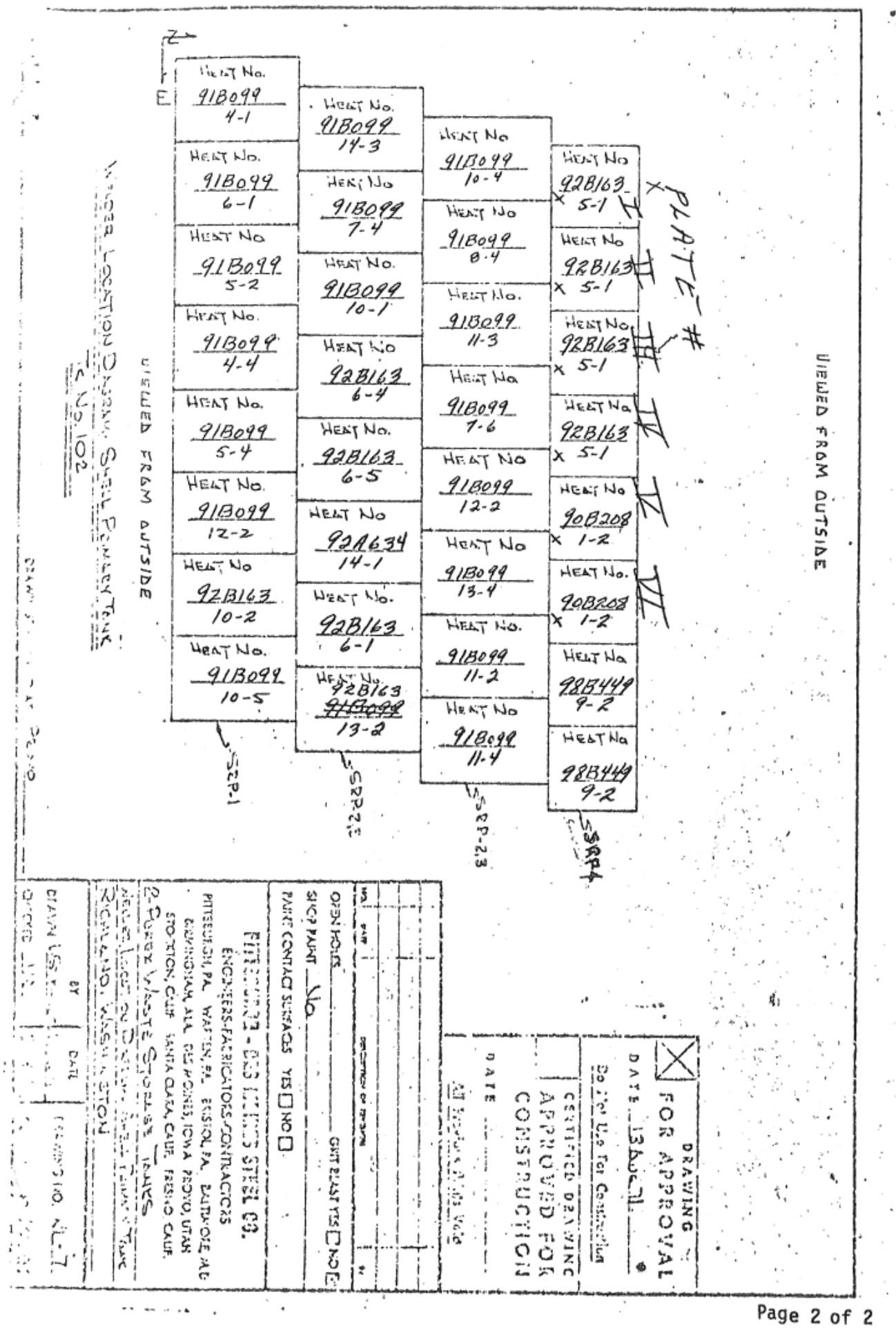


RPP-RPT-54818, Rev. 0

App Figure C-2. Plate Laminations Nondestructive Test Report 72-41-1 (Dated 3/27/72) (3 Pages)

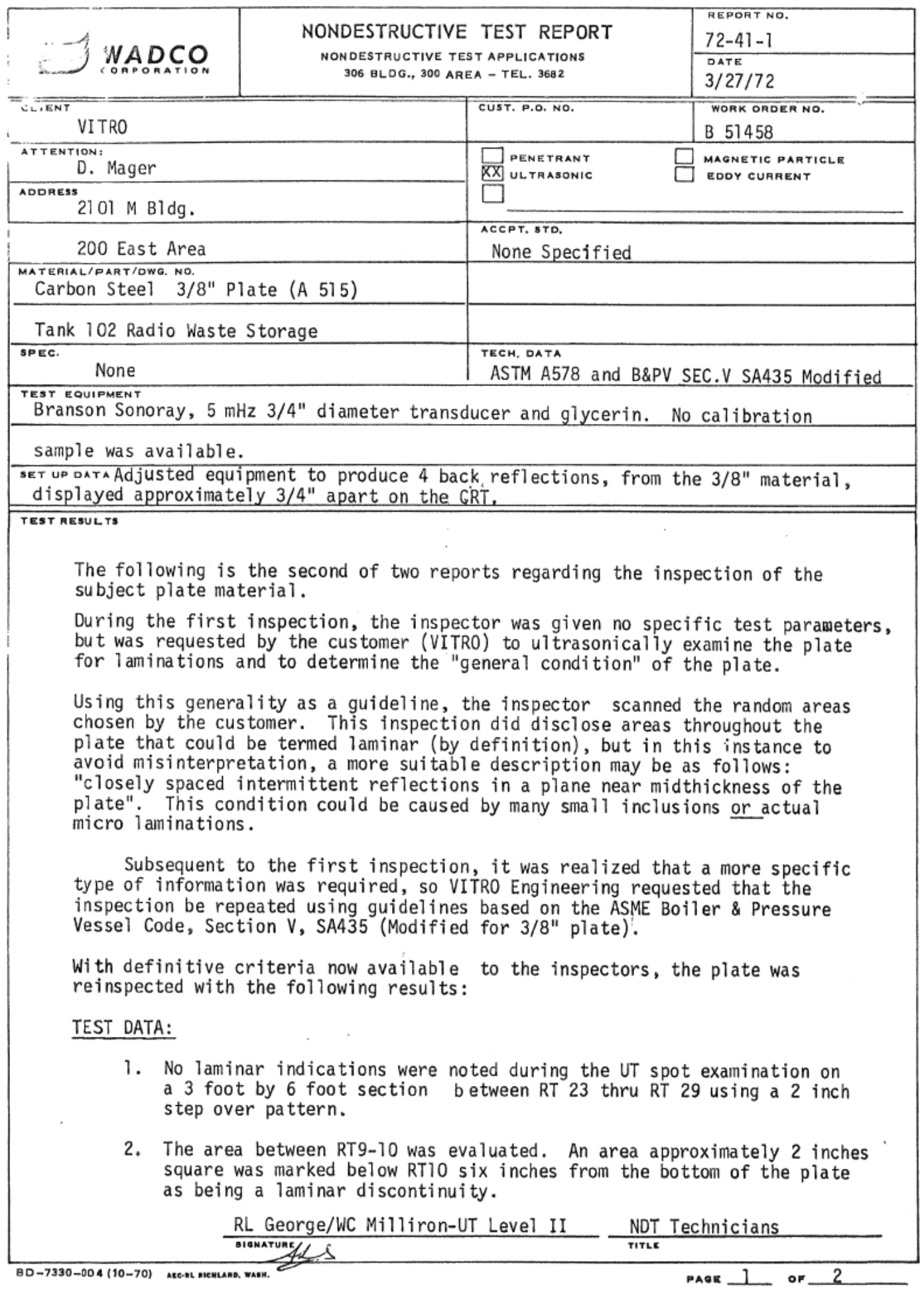


RPP-RPT-54818, Rev. 0

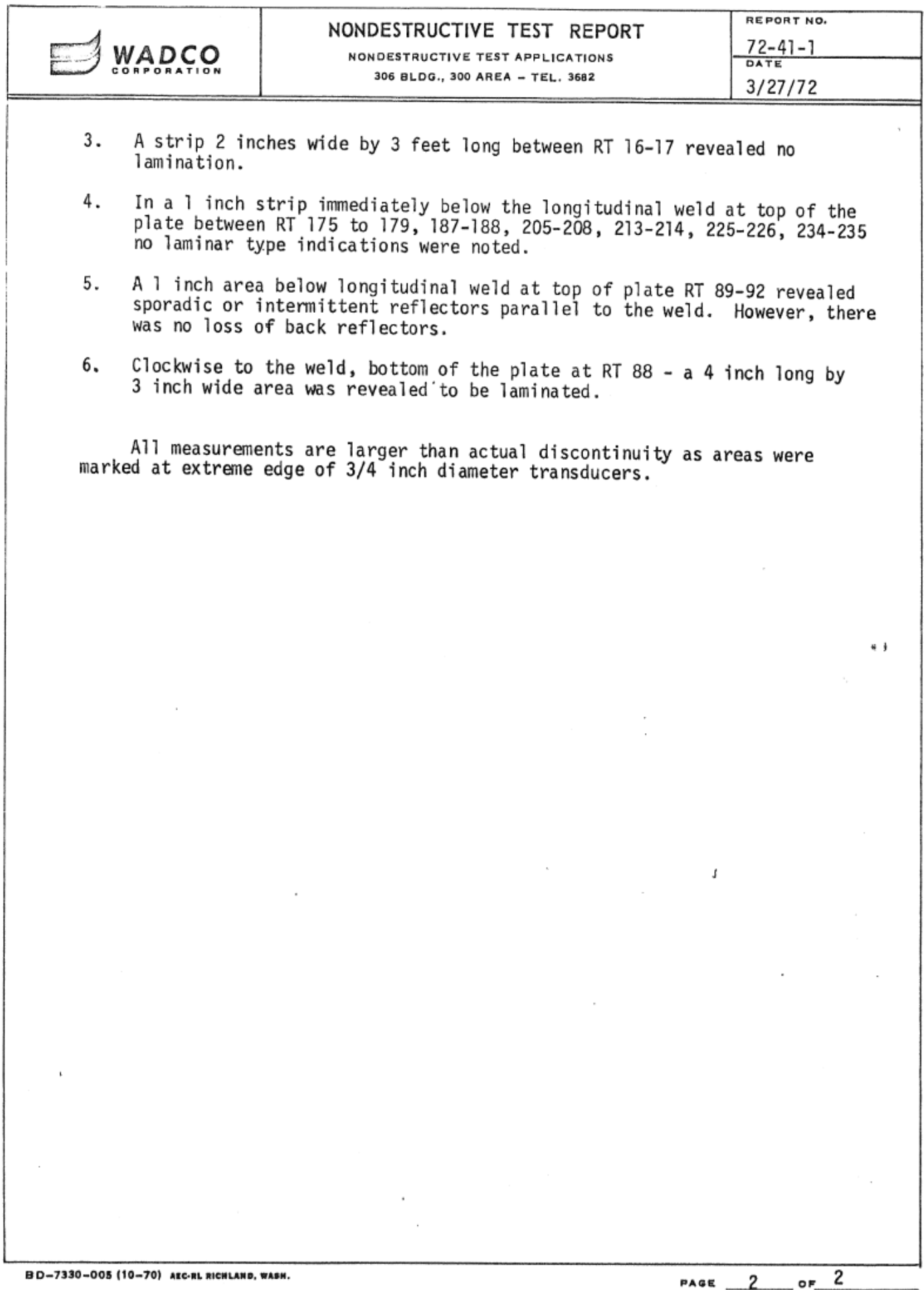




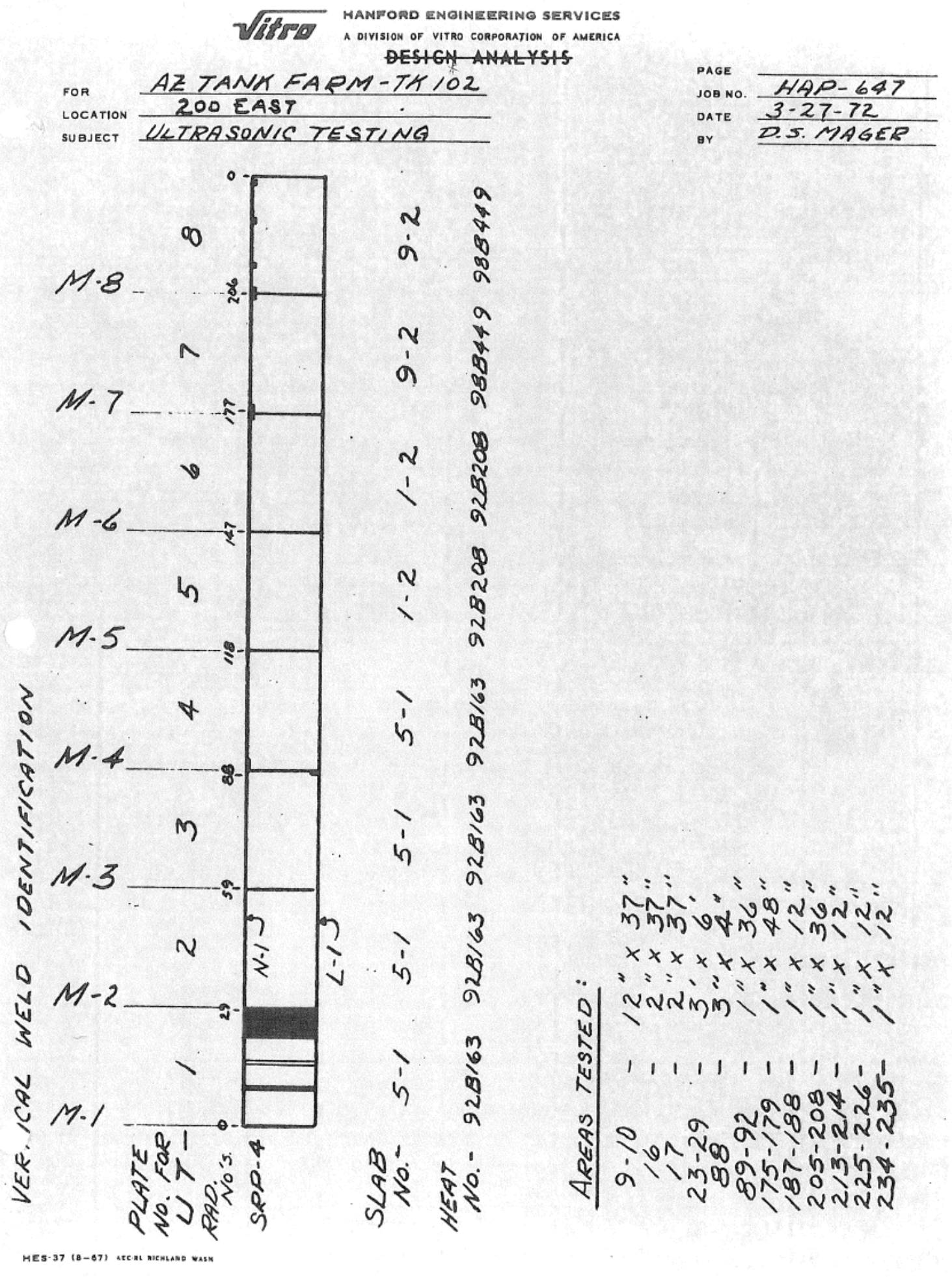


RPP-RPT-54818, Rev. 0

App Figure C-3. Plate Laminations Deficiency or Variation Report (Dated 4/27/72)

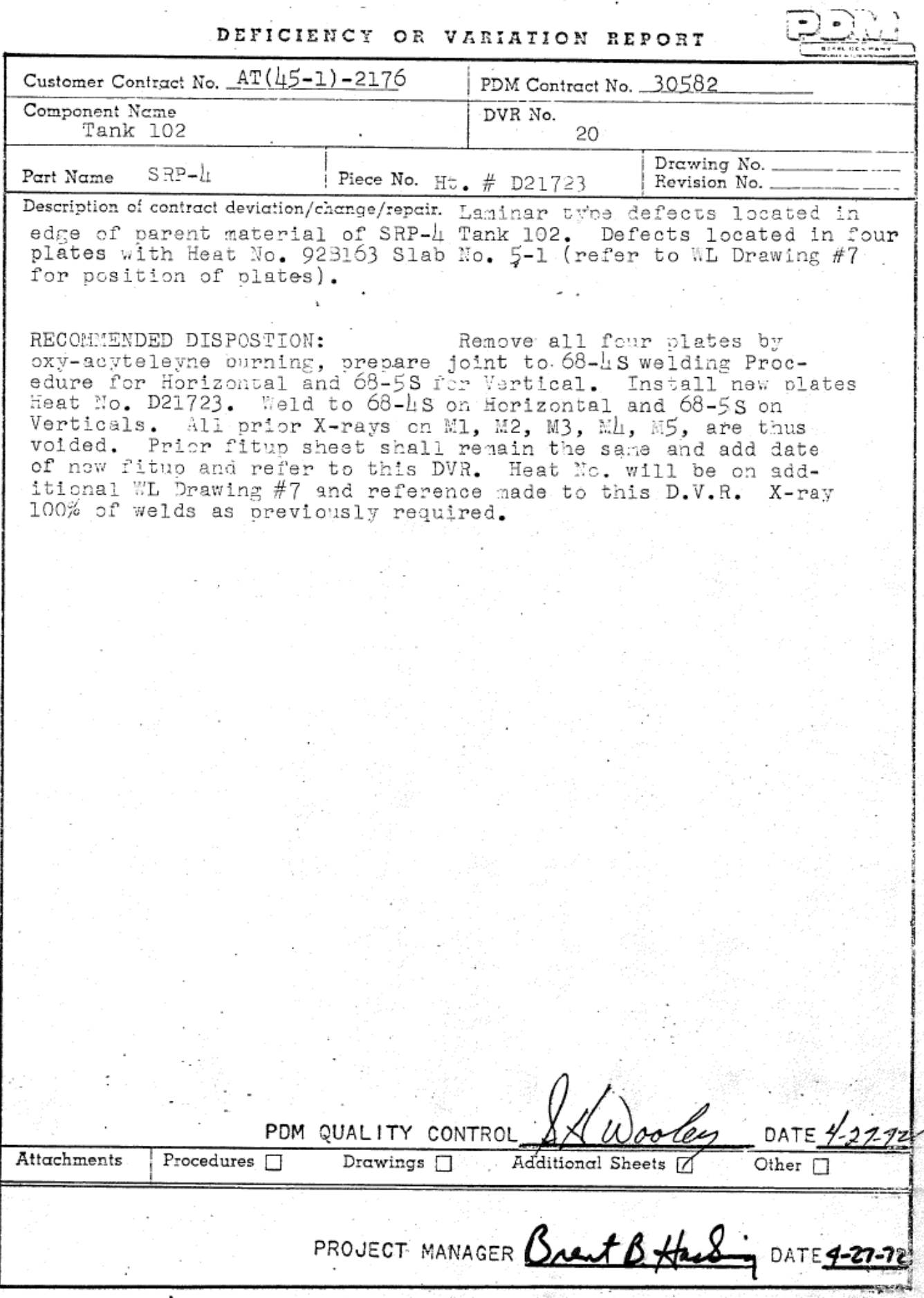


RPP-RPT-54818, Rev. 0

App Figure C-4. Weld Seam E-1 Grind Out Deficiency or Variation Report (Dated 8/25/72)

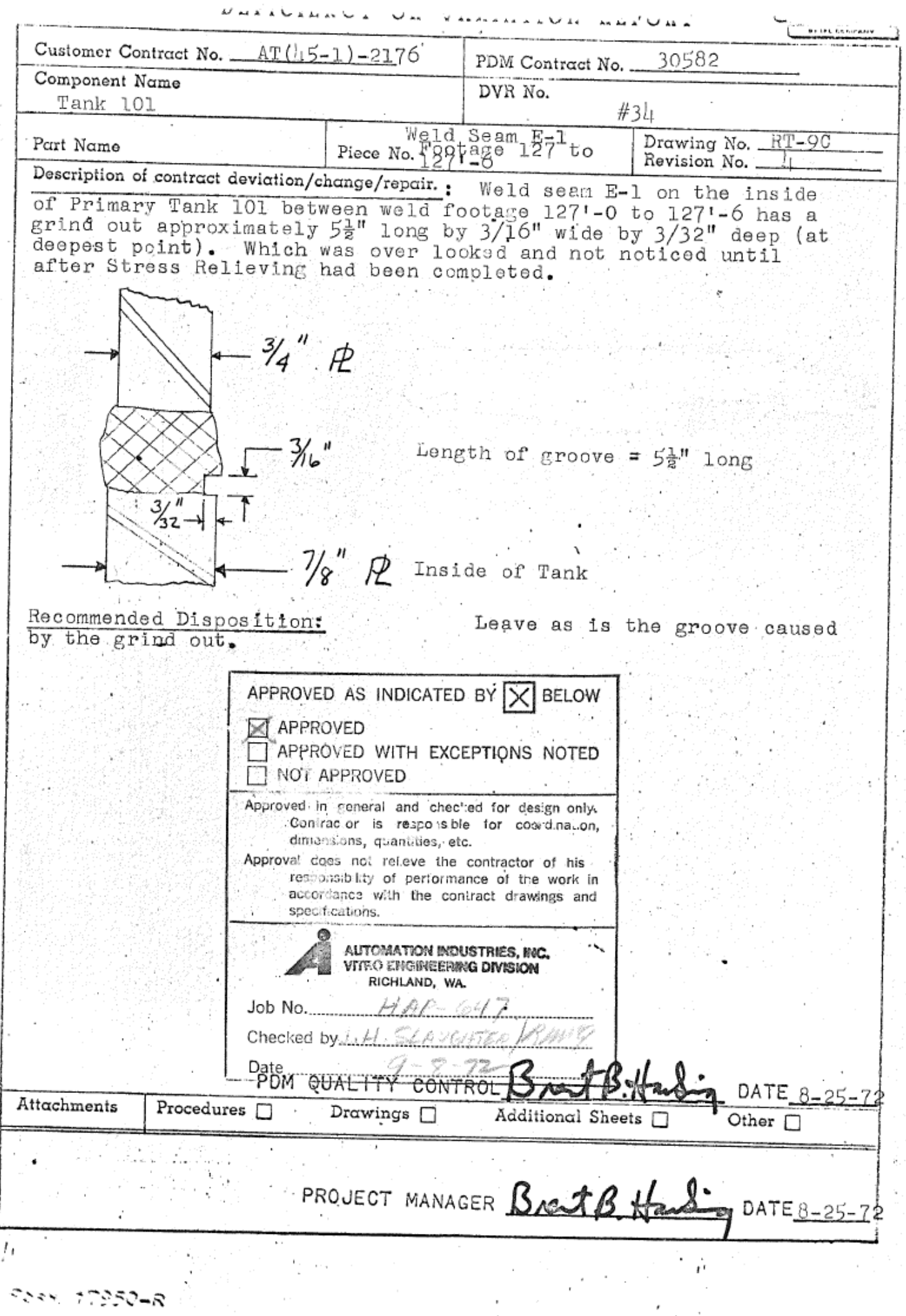




\section{App Figure C-5. Letter from J.H. Slaughter to J.M. Frame Regarding Audit Findings (Dated} 7/13/72)

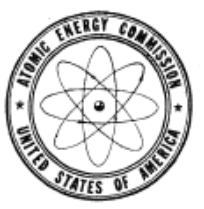

\section{UNITED STATES \\ ATOMIC ENERGY COMMISSION \\ RICHLAND OPERATIONS OFFICE \\ P. O. BOX 550 \\ RICHLAND, WASHINGTON 99352}

July 13,1972

Vitro Engineering

ATTN: J. M. Frame, President

Richland, Washington

Gentlemen:

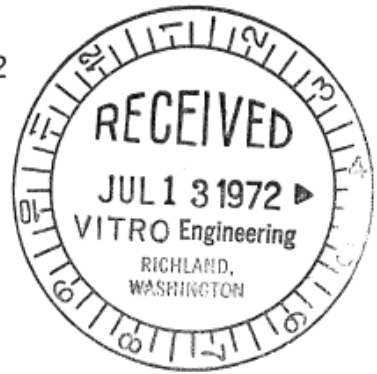

CONTRACT AT(45-1)-2176, STEEL TANKS AND RELATED WORK FOR WASTE STORAGE FACILITY NO. 241-AZ, 200-E AREA. HAP- 647

The subject work was recently audited and a list of findings was compiled. Among those findings are the following:

1. The substitute radiographs from the radiographer's misrepresentation were not filed along with those accepted.

2. An area about six inches long was found on the $E 1$ weld seam of tank \#101 that appeared to be ground out, and not replaced with weld metal. The deepest indentation thereon was $3 / 32$ inches.

3. The inside surfaces of the tanks have experienced pit corrosion.

Please file the missing radiographs in their appropriate places and proceed with a thorough study of items 2 and 3 above and recommend a course of action to be taken to assure that the tanks maintain the desired degree of integrity.

CC: WC Armstrong-ARHCO

CAS Redistribution 7-14-72

B. $\operatorname{Kirz}$

(JMF/GK Already Had Copy)

E. F. Smith
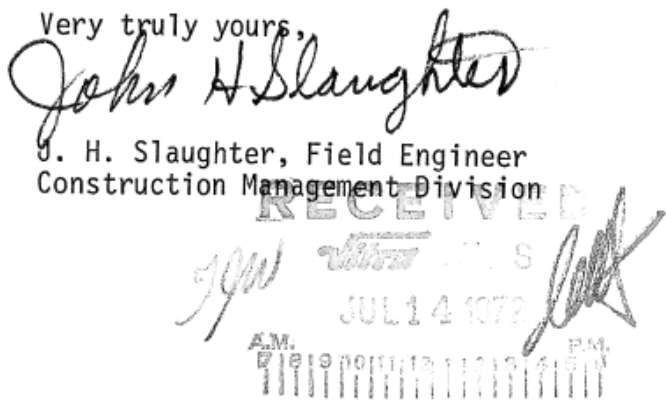


\section{App Figure C-6. Letter from E.F. Smith to J.H. Slaughter Regarding Audit Findings (Dated 7/28/72) (2 Pages)}

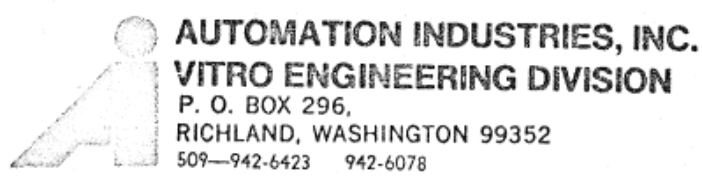

United States Atomic Energy Commission Richland Operations Office Richland, WA 99352

ATTN: JH Slaughter

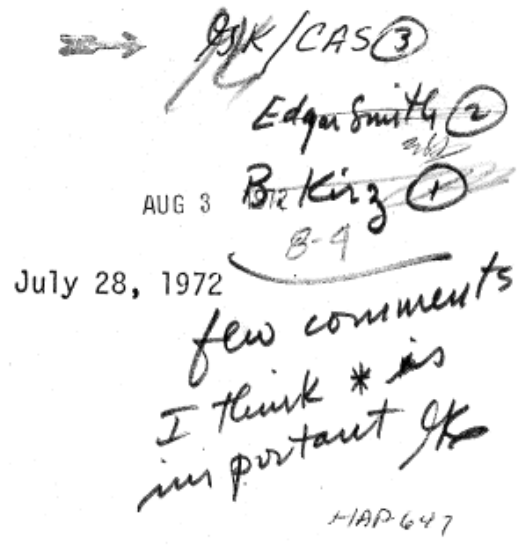

Gentlemen:

CONTRACT AT(45-1)-2176, STEEL TANKS AND RELATED WORK TO PUREX WASTE STORAGE FACILITY NO. 241-AZ

REF: Letter, JH Slaughter to JM Frame, July 13, 1972

The referenced letter referred to an otherwise unidentified compilation of a "list of findings" resulting from a recent audit of the subject work and referred three of these findings to this office. The following comments are numbered in the same order as in the referenced letter.

1. Regarding the falsified radiographs that were detected by our inspection personnel, we do not believe such radiographs should be inserted in the same filing system used forkradiographs, ofsapted. However, they will be suitably identified so that they will not be misconstrued and filed so they are more readily available, and associated with other radiographs.

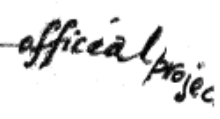

2. With respect to the apparent grinding of the E-1 seam without replacement by weld metal, we find that this condition exists in a 5-1/4" length of the E-l weld seam which joins the $3 / 4^{\prime \prime}$ shell plate to the $7 / 8^{\prime \prime}$ plate forming the vertical extension of the bottom knuckle. In this length there is an aggregate of approximately $2-1 / 2$ inches of

- gouging adjacent to the 7/8" plate that is deeper than the extended surface of the $3 / 4^{\prime \prime}$ plate. The deepest penetration is .020". Inasmuch as the tank has been stress relieved it would be inappropriate to fill this gouge with weld metal at this time. However, the following corrective action will maintain the integrity of the tank and be within the parameters of allowable sharp gouge defects permitted under the specification:

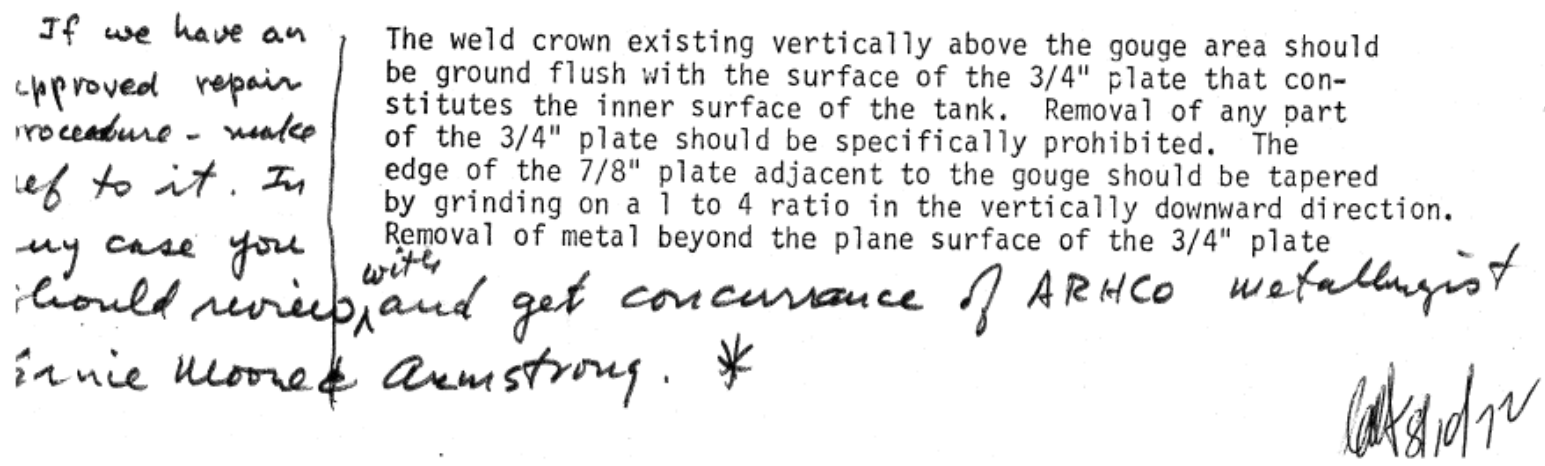


RPP-RPT-54818, Rev. 0

AUTOMATION INDUSTRIES, INC. VITRO ENGINEERING DNISION

U.S.Atomic Energy Commission -2- July 28, 1972

that constitutes the inner surface of the tank should be prohibited. The same method and parameters for metal removal horizontally at the ends of the gouge should be employed. Recognizing that the tank has been stress relieved, extreme caution should be taken in implementing these procedures to avoig impact forces on the tank.and cuenting

3. As to pit corrosion on the inside surfaces of the tank, this, generally, is normal scaling rust action peculiar to the type of construction. In tank 101, however, a five foot depth of water was retained for a somewhat longer period than usual awaiting the time when it could be transferred to tank 102. In checking this area it has been found that pitted areas generally have depths of .007" to .008"; the deepest pit being .010". Other rusted areas appear to have lesser pitting. It is opined that this scaling has not violated the desired degree of tank integrity and no further action is recommended.

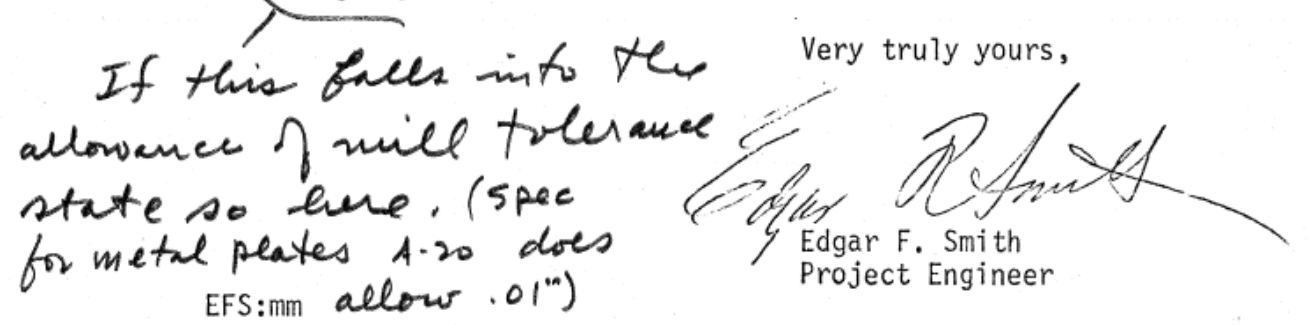

bcc: WC Amistrong

B. Kirz

2as $\Rightarrow$ GKJCAS

A. Short

- EFS/files 
App Figure C-7. Letter from W.C. Armstrong to J.H Slaughter Regarding Weld Seam E-1 Grind Out (Dated 8/24/72)

Atlantic Richfield Hanford Company

Federal Building

Richland, Washington 99352

Telephone 5099427411

August 24,1972

U. S. Atomic Energy Commission

Richland Operations offlce

Richland, washington 99352

Attention: Mr. J* H, Slaughter

Engineering and

Construction Division

Subject: PROJECT HAP-647 - TANK FARM

EXPANSION 241-AZ TANK FARM

Contract AT $(45-1)-2130$

Gentlemen:

The structural effect of the unrepaired weld grindout in the $\mathrm{E}-1$ seam inside the 101-Az primary tank has been investigated by our structural engineer, F. R. Vollert, using the data of the geometry survey by Mr. A. Short, Vitro Englneering. As a result, it is considered that the grindout as it exists does not present a struatural threst to the tank. The geowetry of the grindout presents no stress riser condition, and a liquid penetrant test revealed no crack emanates from the grindout base. It is, therefore, reconmended that no corrective action be attempted lest overgrinding result or the benefits of stress relleving be impaired by fillex welding.

The very slight pits noted on the insfde surfaces of the 101- $\mathrm{AB}$ and 102-Az primary tanks are considered by $M x . \mathbb{B}$. I. Moore, the Atlantic Richifield Hanford Cropany metallurgist, to have been caused by water durlng hydrostatie testing. The $101-\mathrm{Az}$ tank will be held in the empty condition which wi11 not propagate pits. Fhe 102-Az tank will be held in a standby condition containing approximately five feet of water at a temperature of $180^{\circ} \mathrm{F}$. It is recommended that the water be maintalned at a pli of 10 or above by the addition of NaOH which experience has shown to inhibit pitting.

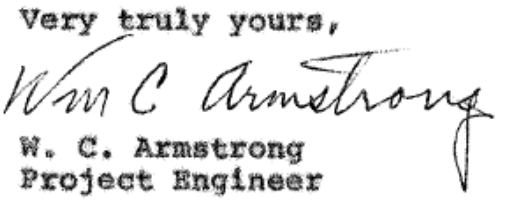

WCA : mwe 
RPP-RPT-54818, Rev. 0

\title{
App Figure C-8. Letter from E.L Moore to W.C. Armstrong Regarding Pitting (Dated 8/7/72) (2
} pages)

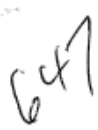

\author{
$x 50 x \# 77868$
}

\author{
Date: August 7, 1972 \\ To: W. C. Armstrong \\ Frow: E. L. Noore OACHAL SIGACD BY \\ Subject: INSPECTION OF THE 101- AND 102-AZ WASTE \\ TANKS
}

Recently, a ąulity assurance audit sas made on tie two new AZ waste tanks. At the conclusion of the audit, the auditor reported the presence of what apgeared to be the slight pitting wider patches of rust foraed on the jrimary tank surface during hydrostatic testing. Subsequentiy, 1 was asked to exanine the tanks and also found very slight pitting on sone areas of welds on the floor and under rust spots on the walls. The pitting on the walls was found under rust patches formed at breaks in the till scale oxide. No observed pit appeared visually to be nore than 0.005 inch in depth.

Conditions in the canks when filled with raw water during hycrotesting were ideal for promotion of pitting in carbon steel. This was quiescent vater, undoubtedly containing chlorides, ard breaks in the will scale where rusting could occur. Pits can develop under this rust first as a rosult of differential acration celis which then develop into passiveactive cells. hence, any crovice, such as under a rust deposit, is a place where the pit is 1ikely to initiate. It is here that oxygen is first used up and the deficiency of oxy gn with respect to the imodiate surrounding area creates an anodic area, arto a differential aeration cell is formed. The loss of passivity in this region follows, croating a potential difference with respect to the large surrounding cathodic areas richer in oxygen. This is the passive-active cell. This condition pronotes corrosion of the anodic areas. Through current flow, chloride, lons in the water transfer into the pit seeping the pit surface active. Pitting corrosion can be reduced and even eliminated by the addition of alkali to chioride containing water. This spiflos

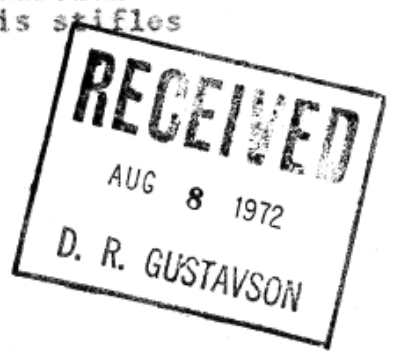


RPP-RPT-54818, Rev. 0

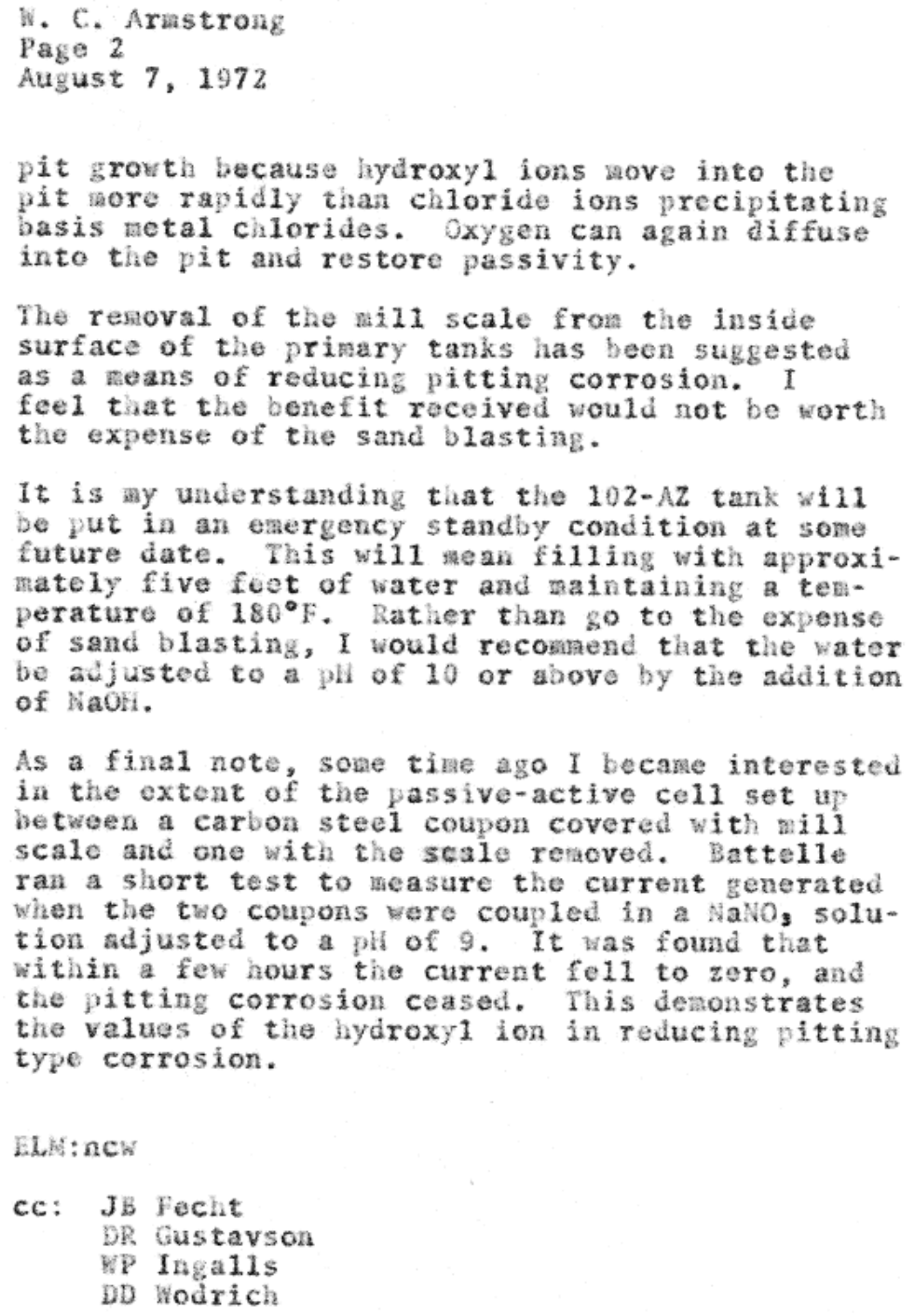

The removal of the aili scale from the inside surface of the primary tanks has been suggested as a neans of reducing pitting corrosion. I feel that the benefit received would not be worth the expense of the sand blasting.

It is $3 y$ understanding that the $102-A z$ tank will be put in an emergency standby condition at some future date. This will wean filling with approximately five foet of water and maintaining a teiperature of $180^{\circ} \mathrm{F}$. Rather than go to the expense of sand blasting, I would recomend that the water be adjusted to a phl of 10 or above by tise addition of haOH.

As a final note, sone time ago I becane interested in the extent of the passive-active cell set ur between a carbon steel coupon covered with mill scalo and one with the stale reaoved. Battelle ran a short test to measure the current renerated when the two coupons bere coupled in a NaNo, solution adjusted to a ph of 9 . It was found that within a few hours the current fell to zero, and the pitting corrosion ceased. This demonstrates the values of the hydroxyl ion in reducing pitting type corrosion.

ELLE: $: \mathrm{nc}$

cc: JB Fecht

DR Gustavson

WP Ingalls

DD Wodrich 


\section{App Figure C-9. Refractory Thickness Deficiency or Variation Report (Dated 8/23/71)}

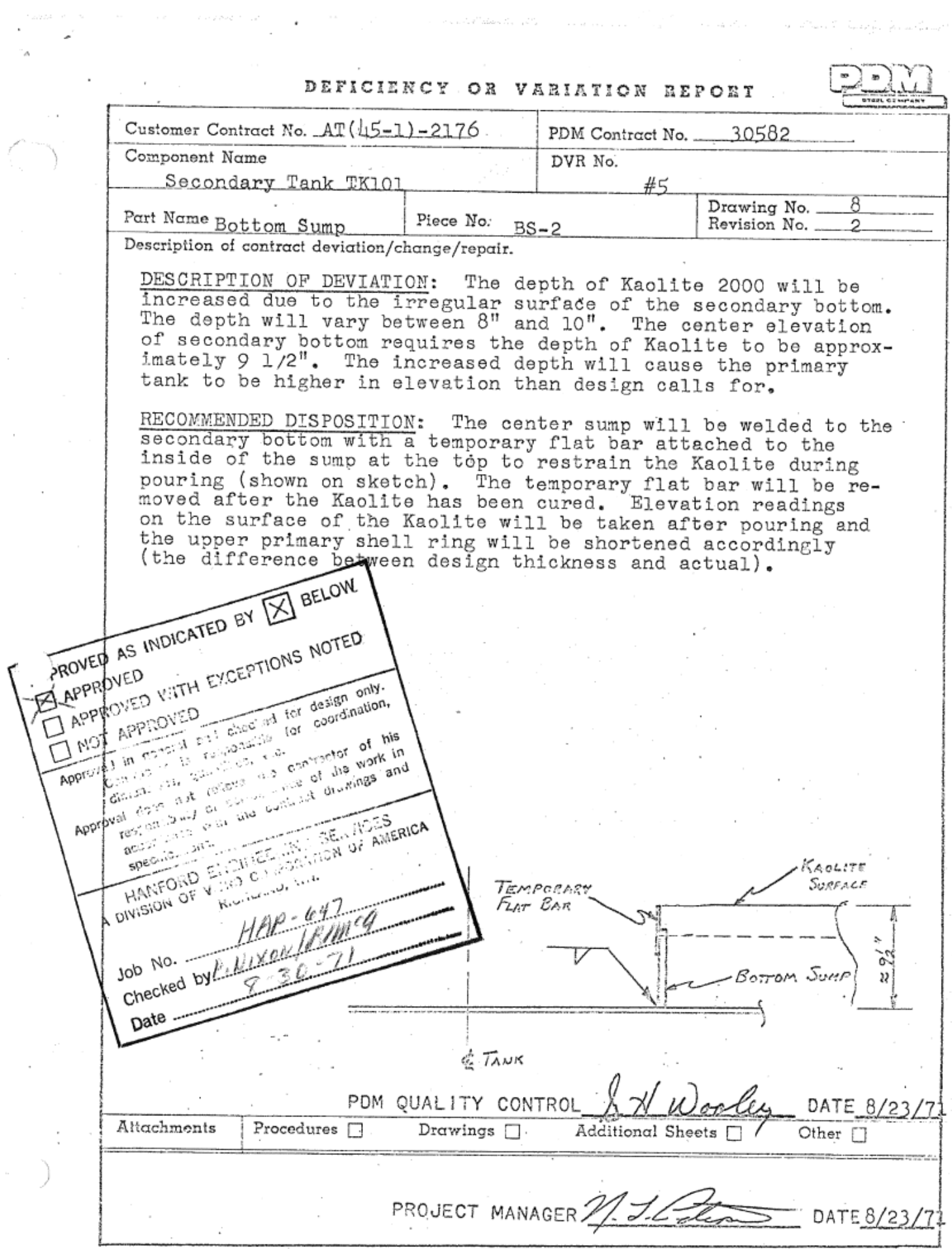




\section{App Figure C-10. Refractory Retaining Band Installed Upside Down Deficiency or Variation Report (Dated 10/6/71)}

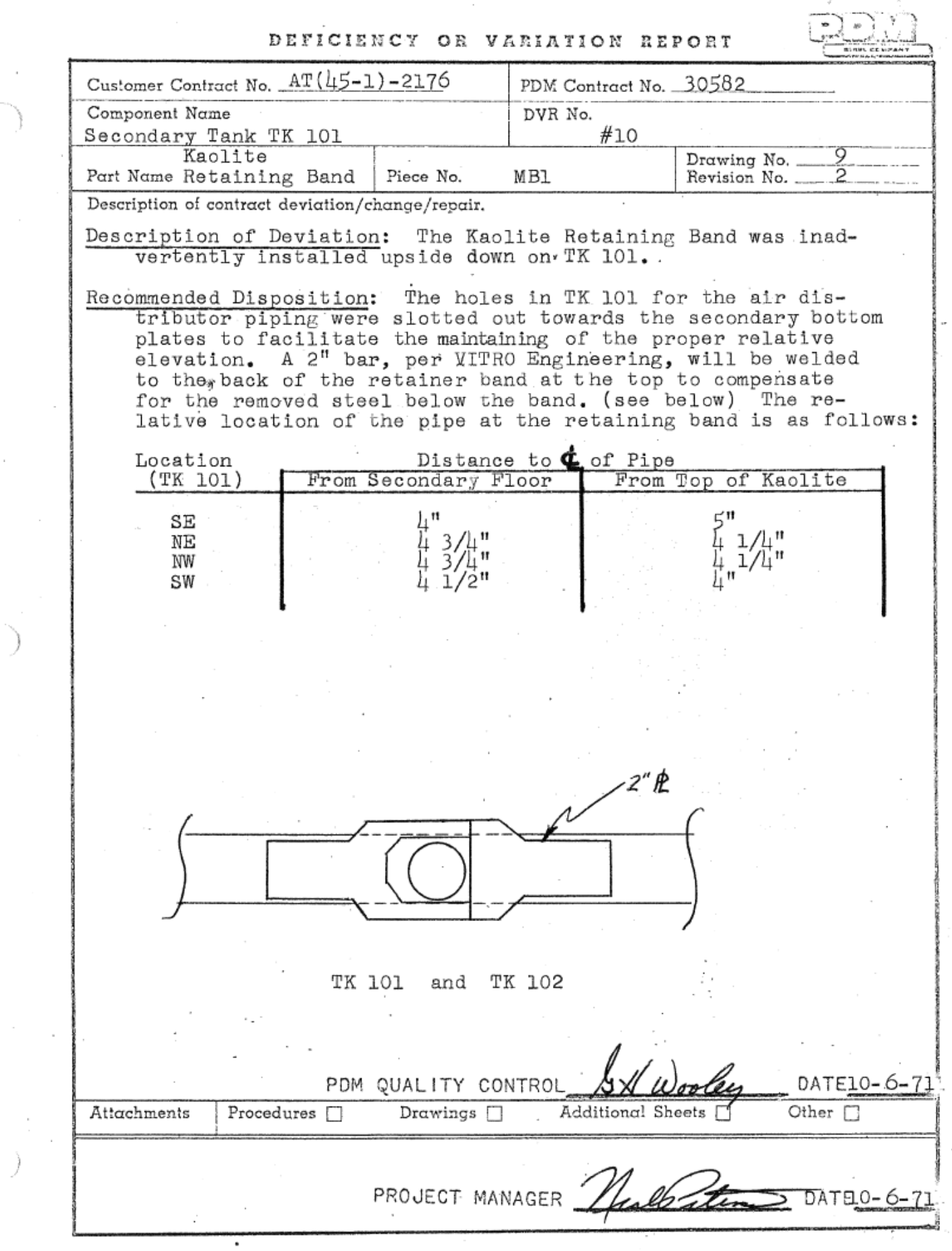


RPP-RPT-54818, Rev. 0

\section{App Figure C-11. Retaining Band Slots and Drainage Holes Deficiency or Variation Report (Dated 11/12/71) (2 Pages)}

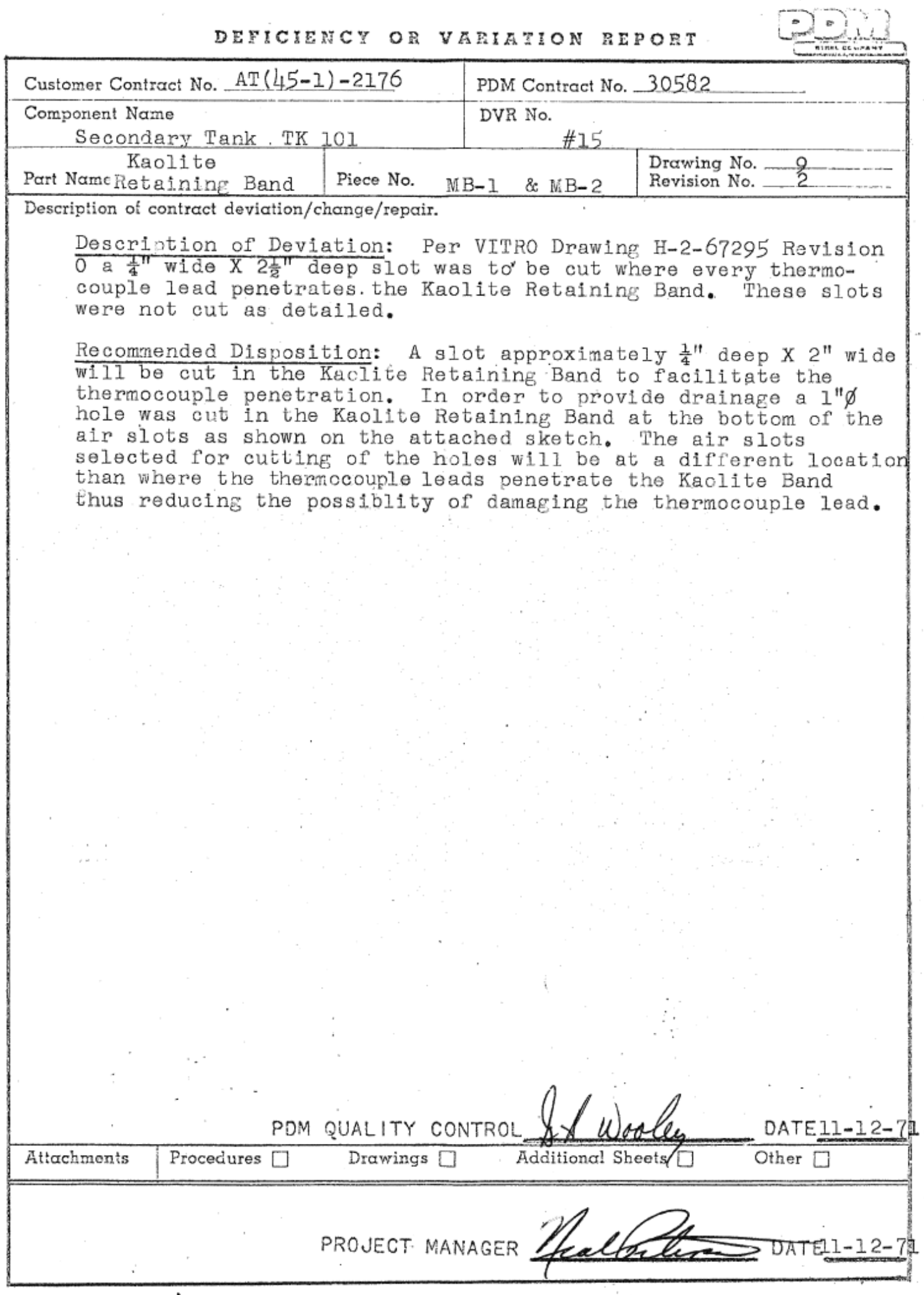


RPP-RPT-54818, Rev. 0

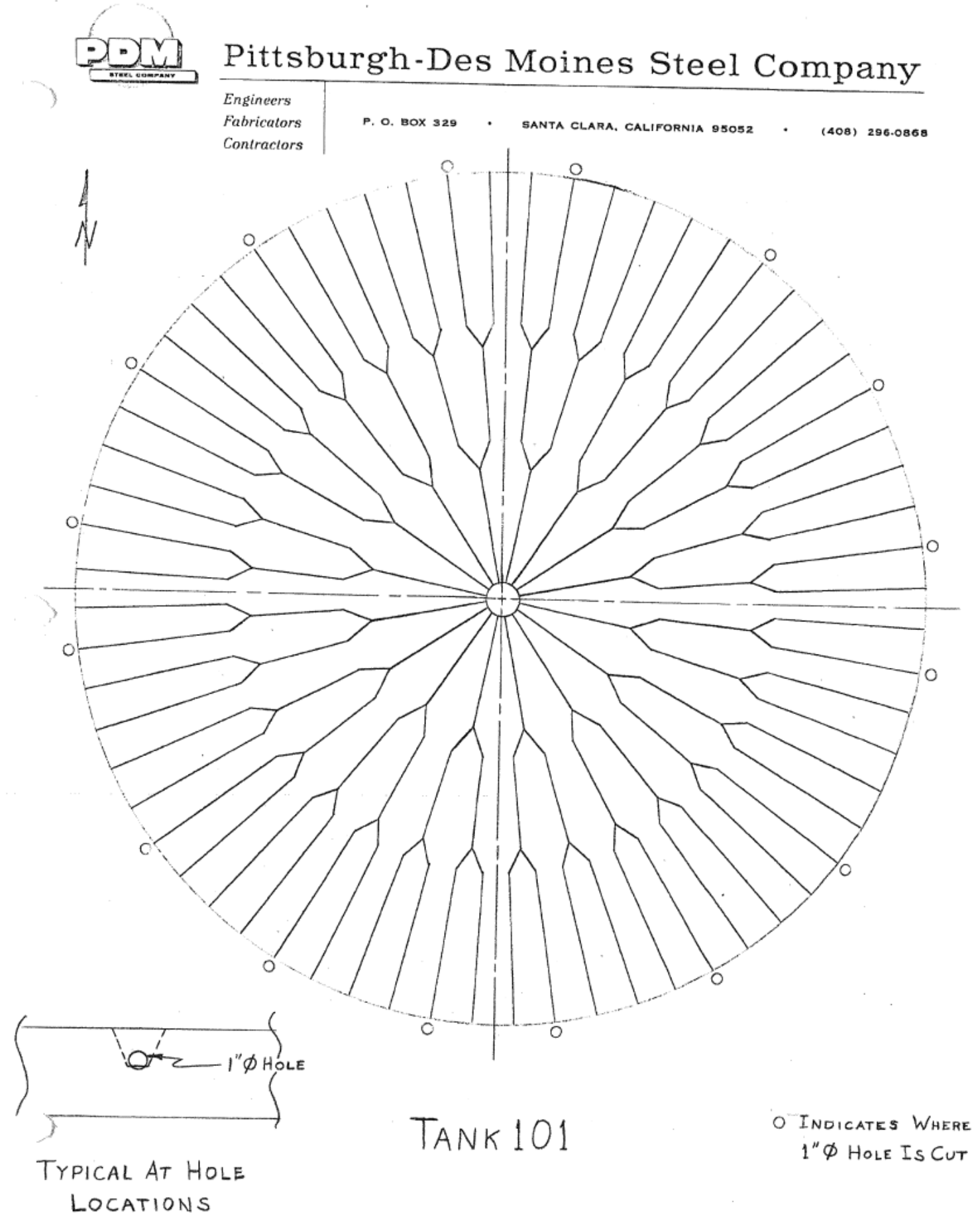


RPP-RPT-54818, Rev. 0

\section{App Figure C-12. Refractory Guidance by Babcock and Wilcox (Dated 6/4/71) (4 Pages)}

\section{Babcock \& Wilcox}

Willard Smith, Inc.
3155 Elliott Avenue
Seattle, Washington

Attention: Willard Smith

Dear Willard:

Refractories Division

305 Norton Building. Seattle, Wash. 98104

Telephone: (206) 622.1496

June 4,1971

98121

office and will letter will confirm our recent

pending Nuclear Waste as our basic recorecent conversation in

Hanford. By copies of Tank Bottoms to be indations regarding your

attempt to out-line of this letter to be installed this sumg the handling and place Babcock \& Wilcox those listed below summer at questions the first Kaolite 2000 and Kaolite $2200 \mathrm{LI}$. that you put place I will attempt to answer we will acknowledge that co me during our conver answer some of the extremly un have detrimental affecontrations of gase Although kerosene spacely that these gases on castable gases such as co2 adversely affecting could produce in the amount created it is the personnel workingental affects with a

leading up have reviewed with

following to the initial tank E.J. Dickson the

originally discuts on this matter.tom project and course of events

Mr. J.D. McCoucussed the use of de. As you may recall have the he recommended lough, at that of detergent for fluill when you your insistence initially against thanager of Engidity with we had no knowled ultimately yielded use of any detergent services, detergent and ledge of the affects his objections problems related would not be held created by addition stating that the use of this additie in any way of

tanks that You asked several questions

The original he been installed ations regarding the two series

20 Special whil project at Savannah Savannah River Projo series of

Special which was speciannah River in 1968 project in Georgi specially formulated for this project. 
RPP-RPT-54818, Rev. 0

Babcock \& Wilcox

Willard Smith, Inc. June 4,1971

Page two

The service rendered by the castable was said to ge good with a possible exception of large sections near the perimeter which were pushed out by the pressure of the knuckle during stress relieving. None of the surface affects noted at Hanford were observed at Savannah River. The more recent tanks installed at Savannah River in 1970 were constructed of Kaolite 2000 . These tanks have now been stressed relieved and I understand that everyone is happy with the results. None of the large cracks occured this time probably as a result of a solid steel band around the perimeter of the Kaolite pad.

You asked about the method of placement in both Savannah River projects. To the best of my knowledge the first project was accomplished by direct placement of material as discharged from a paddle type plaster mixer adjacent to the section being poured. The latter project was mixed in the same paddle type mixer and pumped to the appropriate pad site by a standard concrete pump. No lubricant materials such as detergent were utilized by the contractor, however on the first tank as a result of excessive water additions the strength of the placed castables became dangerously low. Subsequent to the discovery of this condition by Babcock \& Wilcox the water additions were corrected to those recommendations and the strength of the second tank bottom was satisfactory.

You questioned me regarding the possibility of over mixing and finishing on the original job at Hanford. My observations which of course were for a relatively short time during the project were that your personnel were mixing and finishing the Kaolite in a manner acceptable to Babcock and Wilcox.

There are two aspects to the question as to whether or not freezing and thawing conditions have any affect upon castable refractories. Generally speaking freezing and thawing of cured castables which contain only the water used in their placement will not be adversely affected. We will concede however that these same cured castables completely saturated by additional quantities of water are subject to deterioration as a result of freezing and thawing. You have asked several times regarding the desirability of placing a dense castable 12 to 16 inches wide around the curcumference of the Kaolite pad. From a structural stand point this would seem desirable, however we are not in a position to run a heat flow study on the affects of temperature in this area upon the sub structural concrete foundation. The customer in this case would have to run a computor study on the heat flow. 
RPP-RPT-54818, Rev. 0

Babcock \& Wilcox

Willard Smith, Inc. June 4, 1971

Page three

The following will be our general recommendations for installation of Kaolite 2000 or Kaolite $2200 \mathrm{LI}$.

WATER ADDITION

For vibrating placement 11.5 to 12 US quarts per 40 lbs. bag. Over additions of water can be detrimental to the strength
of the castable.

MIXING TIME

Before water addition, short duration of mixing is helpful but not mandatory this will help re-mix materials which may have segregated in the bag. After water addition mixing time should be long enough to achieve complete mixing of the water and materials but not to exceed five minutes.

\section{MIXING}

The most commonly used mixer is a paddle type plaster mixer, however other mixes can be used to achieve similar results. PLACEMENT

There are three commonly accepted methods of curing castable refractories including commercial curing compounds, polyethylene cover and surface wetting. The length of curing time is dependent upon the ambient temperatures. At $60^{\circ} \mathrm{F}$ the minimum desireable curing time (that time during which the castable should be kept wet) is twenty four hours. At lower temperatures hydration is slowed, therefore curing time should be extended. At no time during hydration period should the castable be permitted to go below freezing. If a castable is to be cured by external wetting burlap is usually placed on the surface and periodically dampenen with a hose, this method is least desireable as it requires round the clock surveillance. Curing with polyethylene is more practical and it would be permissable to remove the polyethylene from the castable for a short duration not to exceed forty five minutes for the purpose of form removal. It should subsequently be replaced over the castable for the balance of the minimum period dependent on the ambient temperature. The use of commercially available compounds if properly placed should be the most desireable curing means for and installation of this type. After the compound has been applied no additional concern is necessary about the desireable length of curing time as the curing compound will remain on the castable surface until it burns off during stress relieving by this latter means the only concern temperature wise, therefore will be that the ambient temperature does not go below the freezing point. 
RPP-RPT-54818, Rev. 0

Babcock \& Wilcox

Willard Smith, Inc. June 4, 1971

Page four

DETERGENT ADDITIONS

avoided. It is our recommendation that the use of detergents be shows a significant reduction in a copy of which is attached relatively small additions of in strength resulting from these tests is Tergex 400 of detergent. The detergent used in done with a Hobart type lo testing was addition proportioned to laboratory mixer with a detergent castable which was the to 1 cup of detergent per 200 lbs. of tank installation. I think used during the original Hanford that no direct correl hink it only fair, however to point out techniques and the actual fielween this laboratory testing pumping equipment can be field condition created by your understand why our laboratory in both density and strength whent shows significant reduction first set of tanks at Richland wh test samples taken from the strength significally higher than show increased density and

does not officially I would like to say and Babcock and Wilcox or Kaolite 2200 LI are which of the two materials Kaolite 2000 Kaolite 2000 because of its hed, however we would tend to favor recent successful project higher compressive strength and the River. On this matter I woulding this material at Savannah materials are to 1971 as you have indicated an site by approximately July 22, insure a place in our allow sufficient time for rail-shipmente and at the same time questions regarding for rail-shipment. Should there be any receiving copies of this letter plations by yourself or others and I will attempt to clarify it.

Very truly yours,

BABCOCK AND WILCOX

JLT $: m t k$

JAMES L. TRUMBULL District Sales Manager

$\mathrm{CC}:$

Mr. Bob Wendlandt

Mr. E.E. Smith

Mr. Neil Peterson

Mr. E.J. Dickson

Mr. J.H. Slaughter

Mr. W.C. Armstrong 
RPP-RPT-54818, Rev. 0

\section{App Figure C-13. Protection of Kaolite - Action Taken (Dated 12/16/71)}

TO $\frac{\text { Al Short/Vitro }}{2101-M \text { BldG. }}$
FROM LF Smith
SUBJECT Tank Farm Expansion, 241-AZ Tank Farm

Protection of Kaolite

Our telephone conversation at 3:30 pm, this date, is confirmed; you were directed to take immediate action (and implemented today) to protect Kaolite in Tank 102, as follows:

Kaolite is to be covered with "Visqueen", propped up by horses or by other suitable methods with space heaters placed above the Kaolite. The warm air should be circulated by fans or other means.

These steps are taken in the interest of removing excess moisture so that frost action will not damage the Kaolite. Upon removal of the excess moisture, protective measures should be taken to prevent additional moisture entering the Kaolite.

It is understood that core samples are being taken and will be tested early tomorrow morning to determine potential damage from frost action. Preliminary information from Babcock \& Wilcox's Seattle representative, Jim Trumbull, who was contacted this date as soon as the frost problem became known, indicates that excess moisture (that moisture in excess of the normal water for the cured mix) can reduce the strength of the Kaolite when it is subjected to freezing-thawing cycles. Further confirming data relating to frost problems will be sought from Babcock \& Wilcox's technical personnel by telephone on December 17 at 10:30 am.

EFS:mm
cc: B Kirz/GW Knoeber
JH Slaughter
WC Armstrong
G. Kligfield
ES Davis
MH Piskadlo/DG Lien
WD Byrd
CA Sursaw
EFS/files
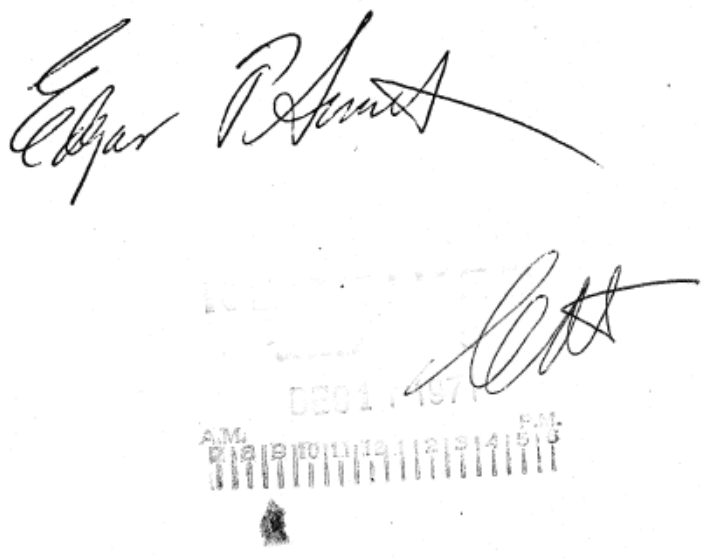

VE-8 $(7-71)$ 
RPP-RPT-54818, Rev. 0

App Figure C-14. Explanation of Frost Discovery and Actions Taken (Dated 12/20/1)

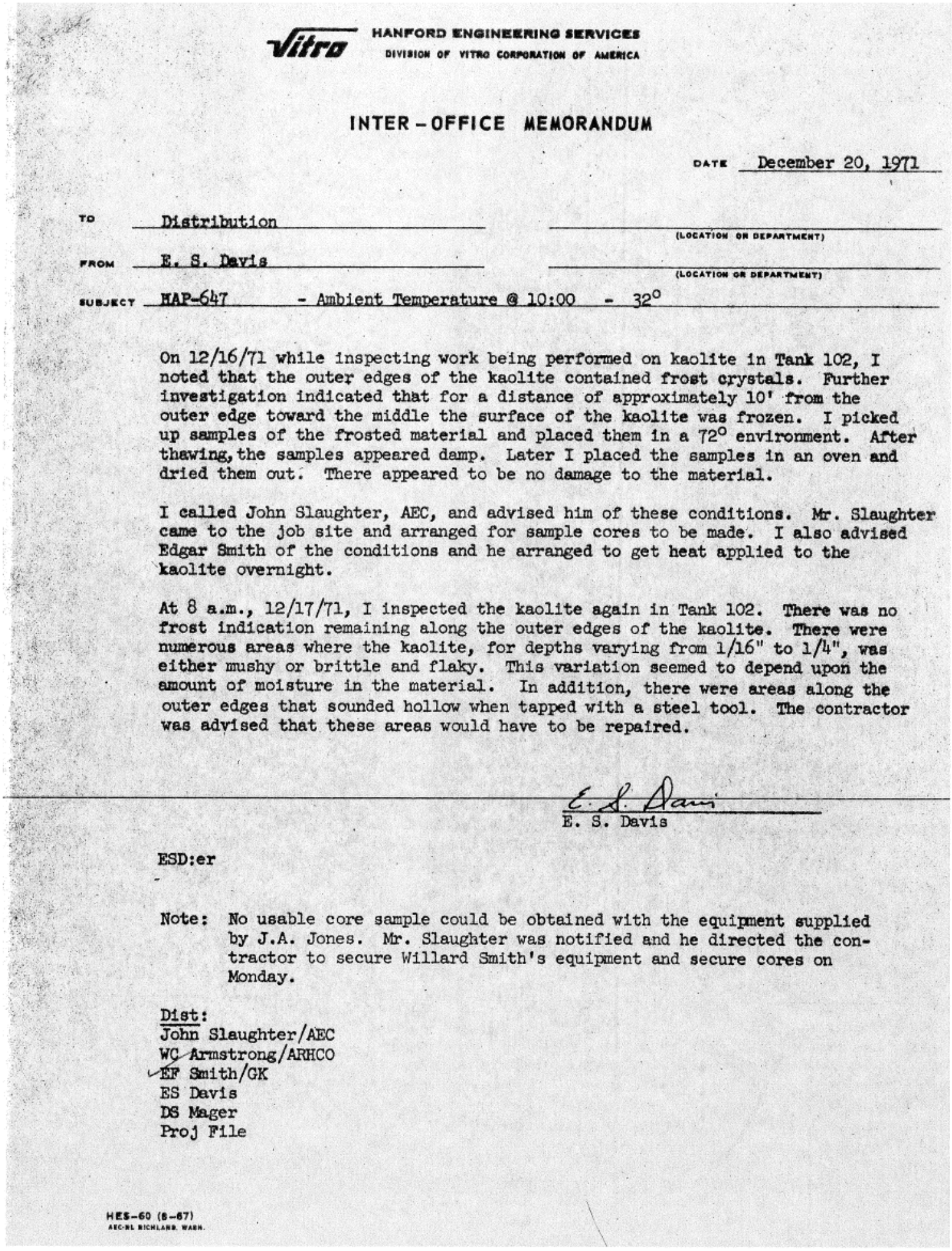




\section{App Figure C-15. Application of Auxiliary Heat to Tanks AZ-101 and AZ-102 (Dated 12/20/71)}

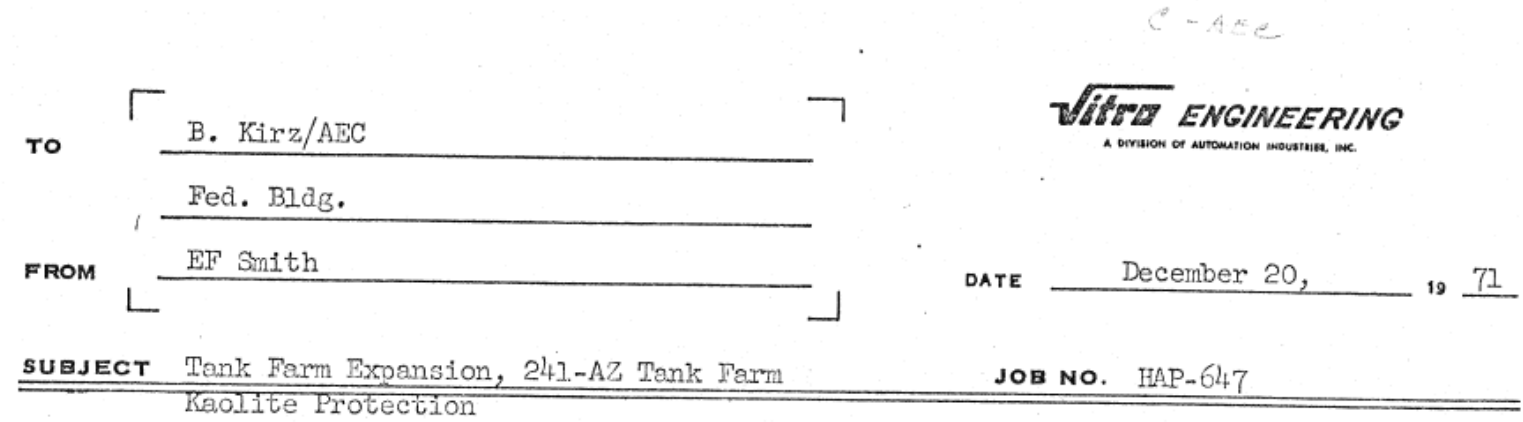

REF: Memo, EF Smith to A. Short, dated 12-16-71.

Auxiliary heat has been provided in both tanks 101 and 102 to maintain temper-

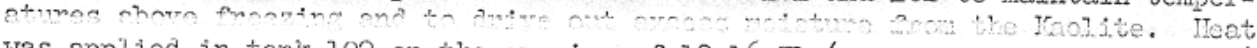
Was applied in tanik 102 on the evening of 12-16-71. (see referenced memorendum); additional heaters vere obtained off-site and were available for both tanks on 12-18-71. Satisfactory temperatures have been maintained since that time.

Preliminary information regarding freeze--thaw cycles of Kaolite containing excess moisture (see referenced nemorandun) is confirmed. Several telephone conferences with Edward Dixon, who heads up Technical Research for Babcock \& Wilcox of Atlanta, Georgia, have pointed out that ice formation in fully saturated, light weight castables vill break down the granular structure resulting in a loss of strength. A more detailed transcript of the telephone conference on 12-17-71 is in preparation. Mr. Dixon has been most cooperative and stands ready to assist us in every vay possible with recommendations for repair of Kaolite that has been damaged by frost action. His contribution will be most valuable when the extent of damage has been determined by testing can core samples and the Kaolite has been dried sufficiently so that repairs
can be

It was not possible to obtain core samples on 12-17-71 with available on-site equipment because of the restricted working height under the elevated bottom plate of tank 102. Willard Sinith, the subcontractor who pleced the Kaolite, is on-site today and has obtained four core samples (one from each quadrant). These core samples are now in the test laboratory and it is anticipated that strength tests will be condivted tomorrow after appropriate oven-dryins to eliminate excess moisture.

Mr. James Trumbull, the Seattle representative of Babcock and Wilcox and who has been designated as Mr. Dixon's perscial representative, will arrive in Richland tonight. He will visit the job site early tomorrow morning and will keep $\mathrm{V}$. Dixon informed of entual conjtions. It is antictpated that the strength test results will be available during his visitation at which time nore detailed recomendations can be made. With the technical guidance and consultation with representaives of Babcock \& Wilcox who furnished the Kaolite, satisfactory repair of the refractory damaged by frost action will be effected.

We will continue to keep you appraised of future developments.

EFS: $: m$

cc: GW Knoeber/JH Slaughter WC Armstrong JM Frame/G Kigfield ES Davis/A Short MH Piskadlo/DG Lien

WD Byrd $\rightarrow$ CA Sursaw EFS/files

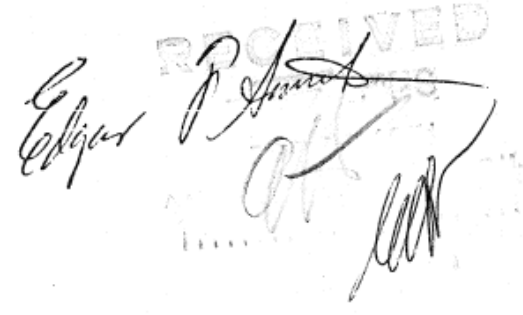

VE-8 (7-71) 


\section{App Figure C-16. Stress Relieving Deficiency or Variation Report (Dated 5/4/72)}

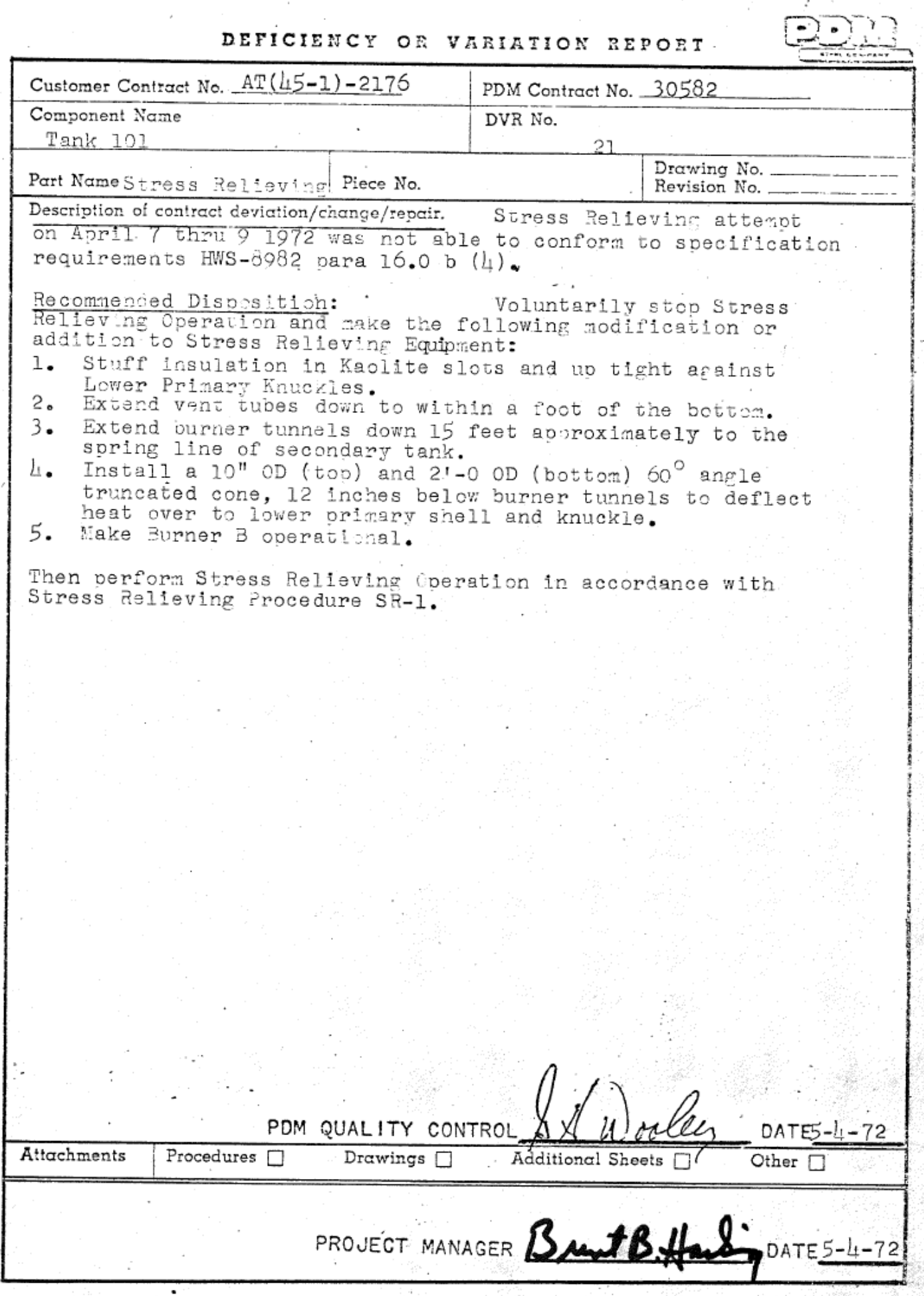


RPP-RPT-54818, Rev. 0

\title{
App Figure C-17. Radiography Misrepresentation Memorandum (Dated 8/6/71) (2 Pages)
}

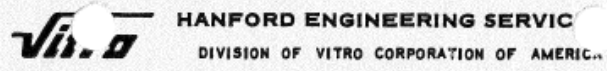 \\ INTER - OFFICE MEMORANDUM
}

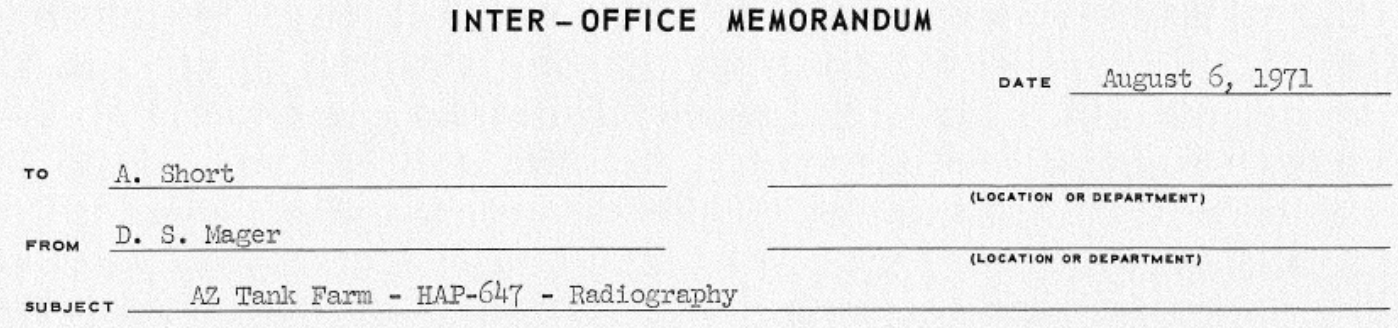

I visited the $A Z$ tank site on the morning of $8 / 3 / 71$ and requested the opportunity to review the radiographs that were available at that time. The reason for this request was to allow me to update the status of weld acceptability and prevent possible delay of lowering the tank bottom as scheduled for $8 / 4 / 71$. Gary Wooley, PDM Quality Assurance Manager, presented me with a.lJ of the radiographs requested, and indicated that eleven repairs were necessary prior to final weld acceptance and tank lowering.

Upon subsequent review of the radiographs received, it became evident on one weld, $B-17$, that the areas $12-13$ and $13-14$ did not match the adjacent areas, 11-12 and 14-15. I inmediately notified G. Wooley (Neil Peterson, PDM Project Ingineer present) of the weld misrepresentation, however, no explanation could be provided for the error. I further stated that I could recall the surface indication shown on the radiograph in question as being the same on another film, and I would attempt to positively identify the actual weld area. This I did, and found that the weld area identipied as $B-17,12-13$ and $13-14$, were actually radiographs of weld B-15, 2-3 and 1-2 respectively. Further review of the remainder of the radiographs submitted this morning revealed a similar situation on weld B-13 (area 14-15).

The radiographer, Harvey Lambert, was surmoned to the site by PDM to provide an explanation for the error. He could not clarify the cause for the error. At this point, I requested $G$. Wooley to re-x-ray the three areas in question.

The following morning, $8 / 4 / 71$, G. Wooley reviewed the repeir radiographs and the reshots requested at 2101-M BIdg. We noted that in addition to the three areas requested for re-x-ray, a fourth area had been radiographed. Filn comparison revealed that there was no correlation between the four actual weld areas and the orlginal film used to represent those areas.

As I investigated further, I found that the veld area identified a.s B-13, 13-14 and 14-15 were actually radiographs of weld B-15, 18-19 and 19-20 respectively.

It is significant to note that all four areas not radiographed correctly are under the temporary truss supports. This makes it necessary for the radiographer to move the equipment from the top side of the tank bottom to the underside of the tank bottom.

HES $-60(8-67)$ 
RPP-RPT-54818, Rev. 0

\section{HANFORD ENGINEERING SERVIC \\ A DIVISION OF VITRO CORPORATION OF AMERICA \\ INTER - OFFICE MEMORANDUM}
A. Short
HAP -647
P. 2

It is my conclusion, based on the evidence available, that the misrepresentation of weld areas was intentional, solely on the part of the radiographer and/or his assistant, and that his purpose for doing so was to save time and physical labor.

Action taken on my part to assure that the high quality of tank 101 has been maintained was:

a. review and verification of the radiographs of the four weld areas misrepresented.

b. Review of all radiographs previously accepted as a "double-check" of their authenticity.

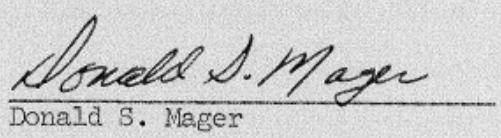

DSM:er

cc: Proj File

DSM/file

LB

HES $-59(12-66$

AEC-RL RICHLAND, WASH. 
RPP-RPT-54818, Rev. 0

\section{App Figure C-18. AZ 102 Knuckle Plates Deficiency or Variation Report (Dated 10/15/71) (2 Pages)}

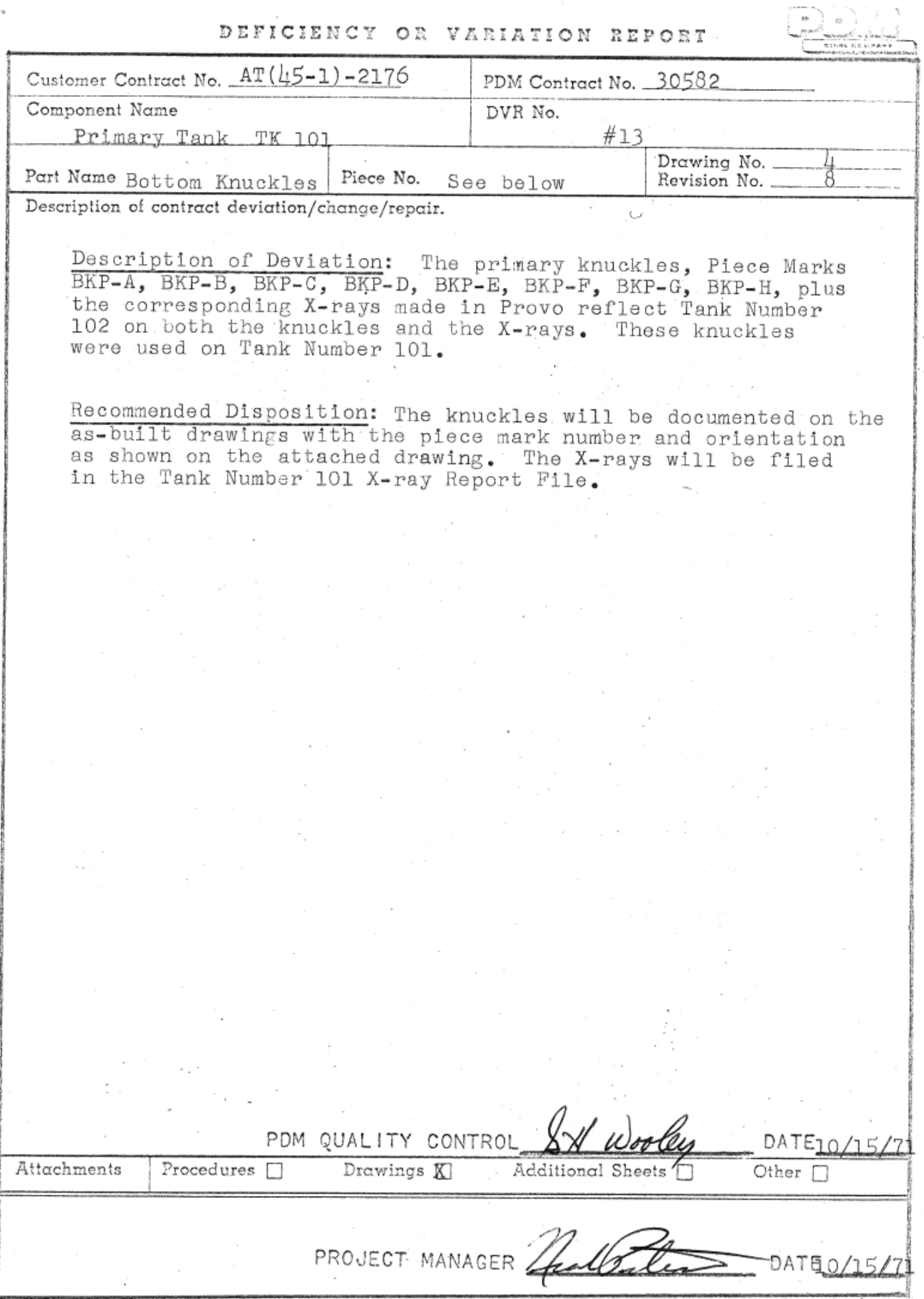


RPP-RPT-54818, Rev. 0

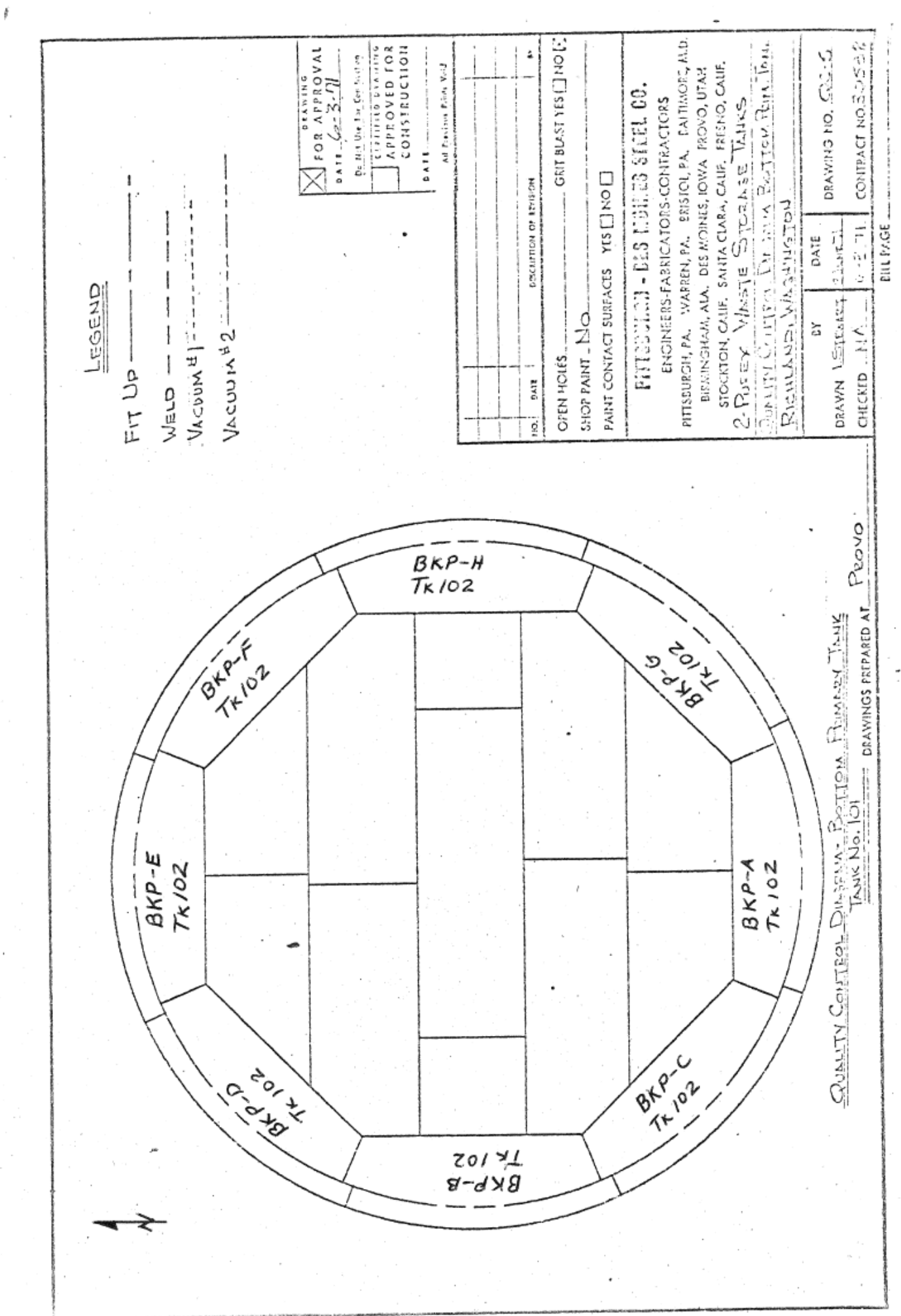


RPP-RPT-54818, Rev. 0

App Figure C-19. AZ 101 Knuckle Plates Deficiency or Variation Report (Dated 11/2/71) (2 Pages)

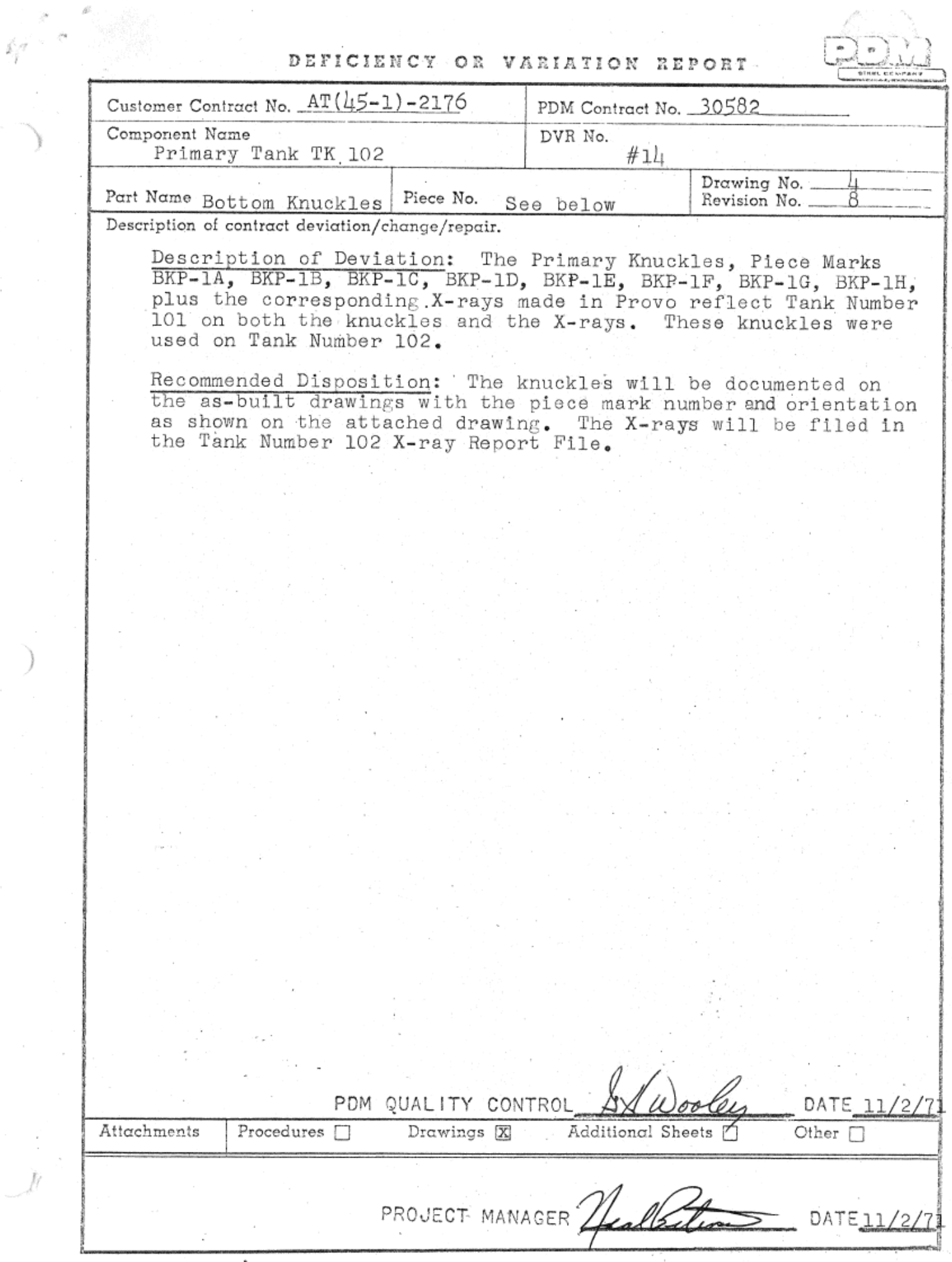


RPP-RPT-54818, Rev. 0

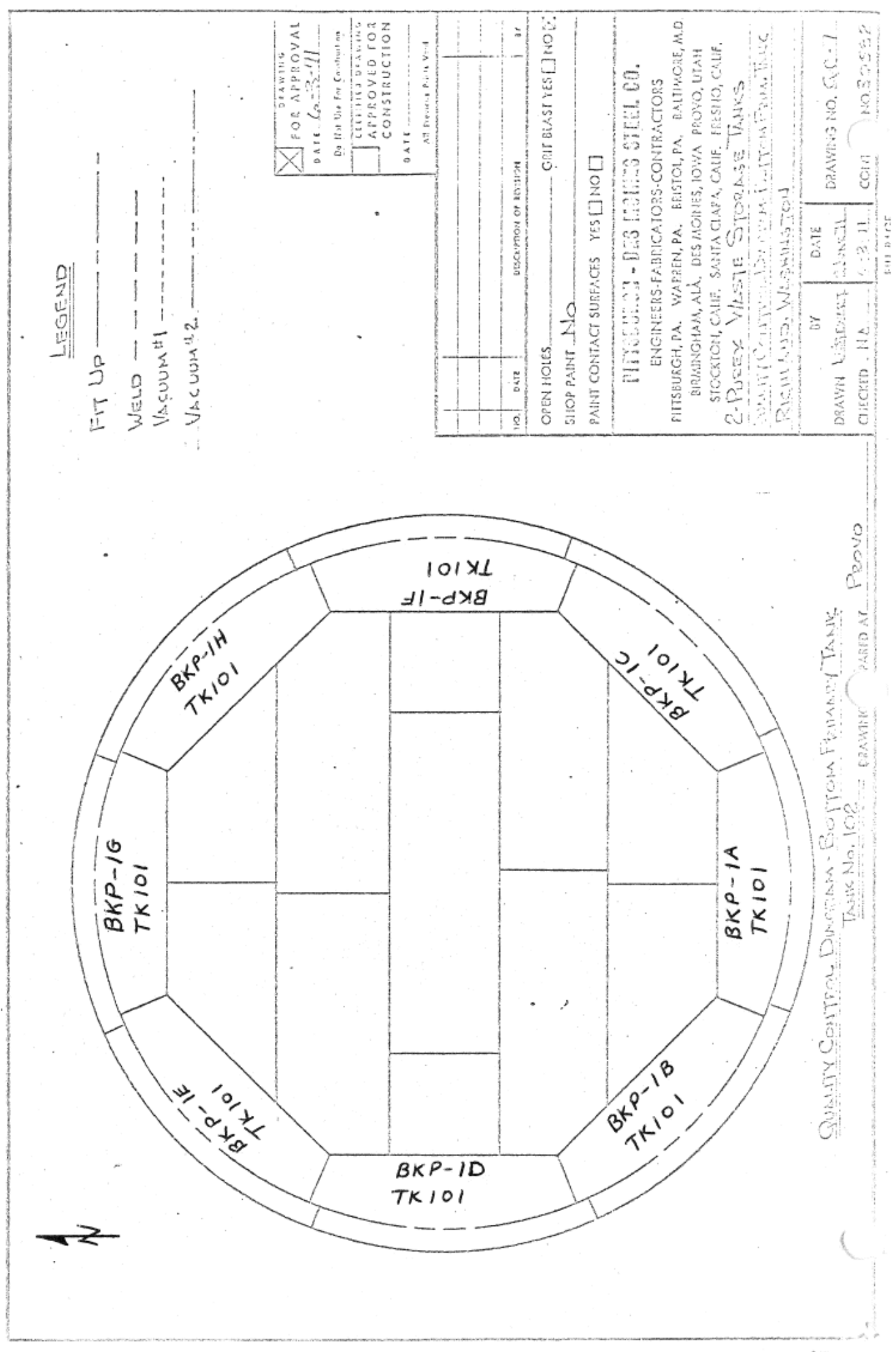

